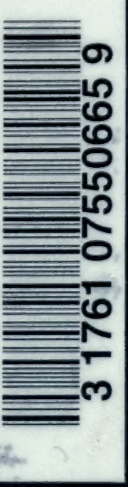









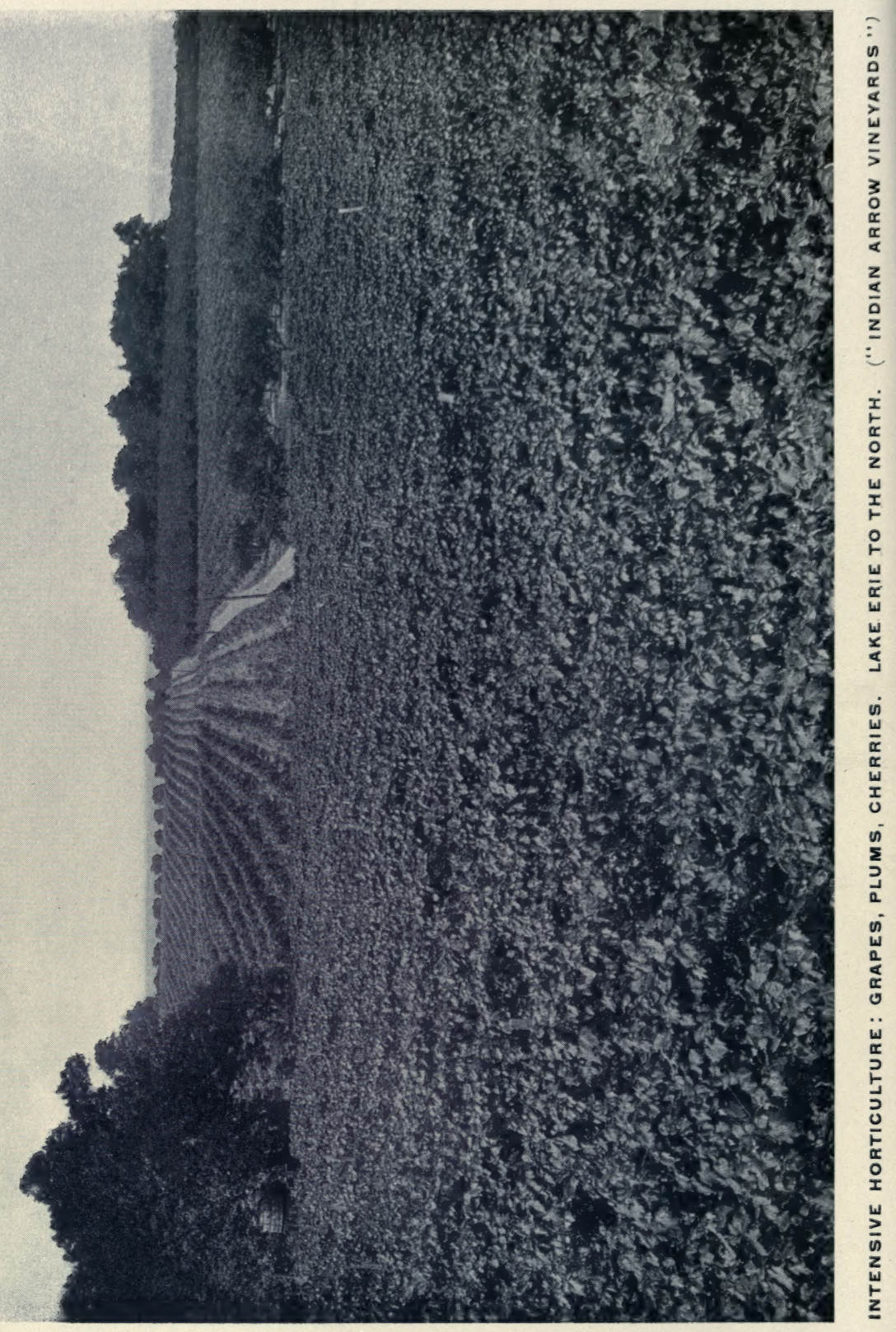




\section{An American}

\section{Fruit - Farm}

Its Selection and Management For Profit and for Pleasure

\section{By}

\section{Francis Newton Thorpe}

Member of the

State Horticultural Association of Pennsylvania

With 21 Illustrations

"The Face of the Master

is good for the Land."

Cato, On Farming.

G. P. Putnam's Sons New York London

Tbe iknickerbocker presg

$$
1915
$$


Copyright, I915

BY

FRANCIS NEWTON THORPE

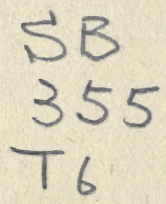

$\frac{671134}{13.58}$

The Iknickerbocker Dress, "mew Work 
to

MARION HAYWOOD

AND

MARION EDGERTON

THORPE 



\section{CONTENTMENT}

Fancy dishes? No. Remember, June's for roses, - not December; Take things in their season;

Vex not life with vanity; Served or serving, take it simply,With good cheer and reason.

After Horace, Carmen XXXVIII. 



\section{FOREWORD}

THE fruit-farm, of which this book is a record, lies in the Lake Shore Valley, on the southern shore of Lake Erie, in Pennsylvania, a region rich in horticulture. The book is a record of many years' experience at home, of much observation abroad, and is offered as a modest contribution to a subject of greatly increasing interest in our own country. Successful horticulture implies ceaseless attention and obedience to the laws of climate, planting, and cultivation, not excluding such elements as soil-fertility, labor, administration, and birds. The biography of any well-conducted fruit-farm is a chapter in the history of success. Horticulture in America is opportunity, but as yet we are merely at the threshold of knowing how to use the land. The illustrations are from photographs taken-with three exceptions-on the fruitfarm whose history is here related.

F. N. T.

INDIAN ARRow Vineyards,

April, I9I5. 



\section{CONTENTS}

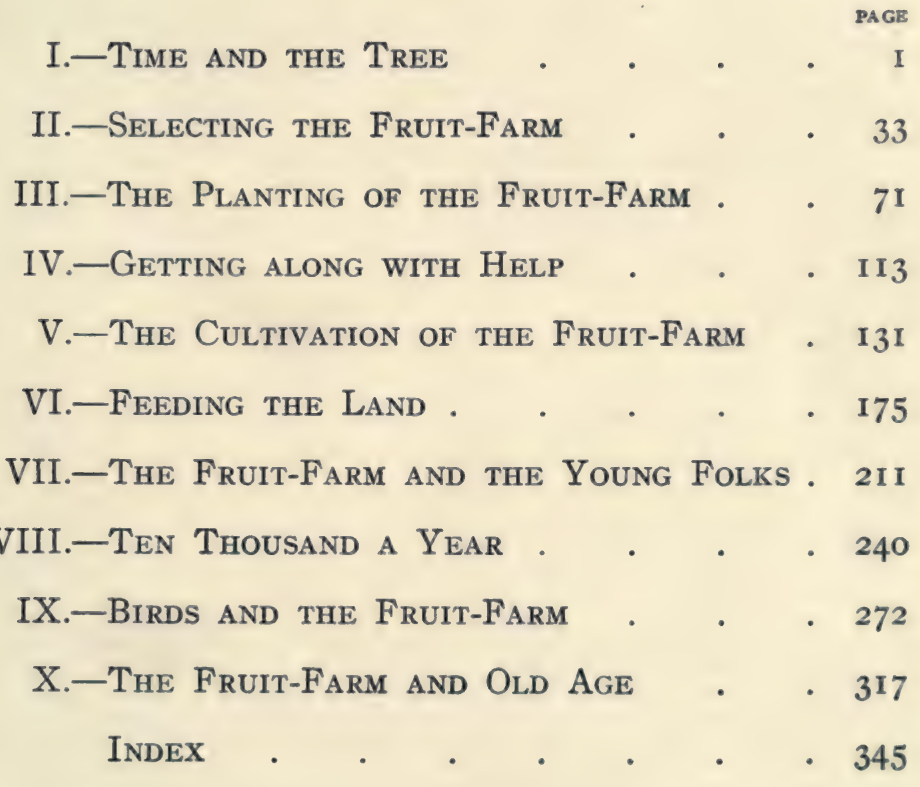





\section{ILLUSTRATIONS}

PAGE

Intensive Horticulture: Grapes, Plums, Cherries. Lake Erie to the North. ("Indian ARrow Vineyards”) . . . Frontispiece

Abundance Plum-Tree; Producing 52 Baskets (I9I3)

Overlooking the Vegetable Garden • 28 An Althea Hedge (In Five Colors) in August 48

In the Cherry Orchard; Notice the Trees (I5 Years Old) Kept Trimmed Low for Easy PICKING . . . . . . . . 64

IN The Cherry Orchard . . . . . 80

Amidst Vineyards; the Chautauqua Hills (1300 Ft.) in the Distance (South) . . . 98

In Grape Time. (Crawford Vineyard.) Lake ERIE to THE North . . . . . . IO4 A TANK FOR SPRAYING $\quad . \quad$. $\quad . \quad$. $\quad 128$ Gang-Plowing . . . . . . . 140 Disc-Plowing . . . . . . $\quad$. 144 The Two-Horse Cultivator • • . ${ }^{148}$ Sowing Alsach Clover . . . . $\quad$ I86 
Horse-Hoeing . . . . . . . . . $\quad \begin{aligned} & \text { PAGE } \\ & \text { I }\end{aligned}$

Spraying a Young Vineyard for Leaf-Hoppers.

(MAllick Vineyard) . . . . . 206

The Steam-Power Sprayer for Trees and Vines 222

Tree Spraying; Plum Trees. (Loop Orchard). 234

The Driveway through the Fruit-Farm . • 254

Packing Fruit for the Market at the PackingHouse . . . . . . . . 260

A Bird Sanctuary. Lake Erie in the Distance 308

A Corner of the Fruit-Farm. Lake Erie in the Distance . . . . . . . 318 
An American Fruit-Farm 



\section{An American Fruit-Farm}

TIME AND THE TREE

SHAKESPEARE'S song, “The Greenwood $S$ Tree," is enough to enroll his name among the immortals. A tree, like a man, requires associations to give it dignity and virtue. Contrast the newly set sprig with the old tree in the orchard: hope and realization; promise and potency; loneliness and association. Time seats the tree in dignity and power. When orchard and orchardist grow old together, they weave associations about the fruit-farm. Labor sanctifies as it breaks with the wild. The house you built, the orchard you planted, the vines which have passed through your hands as cuttings, yearlings, and purple fruit become part of the landscape of your life, old familiar faces which smile even when the sky frowns. And if there were loved ones whose willing hands, now quiet, helped; whose voices, now silent, encouraged,-all has the touch of the altar.

So we grow old with the trees, though their wild 
outburst of new life in springtime seems obliterative of any thought of age. Year after year we follow the season: time builds roots and sprouts into vineyards and orchards; the barren, lonely field becomes whispering trees, swinging vines white with blossom, green and red and purple with fruit. The fruit-farm grows before our eyes, yet never can we see or hear one leaf or one twig grow. The miracle of Nature unfolds before us and we feel the indescribable joy and power of creation. The infants come on together, in cradle and in field, and we measure orchard and vineyard by the years of our first-born. But dates are a foreign fruit. In the Valley, who can truly tell, after a dozen years, the age of vine or tree? We only know that with the years come fruit and more fruit, as with childhood come youth and manhood.

We do not expect a child to do a man's work, nor a young tree or vine to do the work of an old one. Time bids the fruit grow and makes the fruit-farm. Yesterday we marked off the land, and set out the little trees and vines; to-day the children on ladders are picking the red cherries; the trees are fifteen years high. Two thousand bushels? And we ourselves cleared away the primeval forest and planted the orchard. It seems like being present at creation. Did we plant two thousand bushels of scarlet cherries when we set those whip-stocks? Incredible. To-day the purple grapes in the children's baskets. Four tons on the acre? Did we plant four tons of grapes 
when we set out these six hundred and six Concord cuttings each with its fringe of root about a little stick of vine? A thousand baskets of purple prunes? Did we plant a thousand baskets of prunes when we planted those small, spinous, scraggly sprigs? Two hundred bushels of raspberries? And when did my neighbor plant a thousand baskets of peaches? Or were they peach sprouts, a few inches high that now are dark, rich, shining green boughs, bending low with luscious fruit? Time and the Tree, Man and Nature wrought this miracle; a glorious treasury of associations. "Yes," you say; "cherries at three dollars a bushel; grapes at thirty-eight dollars a ton; peaches at one dollar a basket; raspberries at five dollars a bushel, are associations, very tender associations; give me, I pray you, a hundred acres of such associations!"

True, the fruitful orchard and vineyard form peculiar associations with the world at large; such associations as half reconcile the young fruit-grower and his young wife "to try it another year." Suppose five, ten, twenty, fifty years and acres of cherries, peaches, prunes, grapes, berries. What of the associations of a lifetime? Shakespeare knew the meaning of his song, "Under the Greenwood Tree." He knew the harsh world and the kindly tree and would rather entrust himself to wintry weather beneath its boughs than to a wintry world which holds man in no kind association.

There is wisdom in trees. Use the old ones; plant new ones; no fruit-farm is made in a day. 
Therefore mingle the old and the new; the fruiting vine and tree and the young orchard and vineyard of your own planting. Your bearing vineyard and orchard carry the burden of the fruitfarm; while the young vineyard and orchard are growing, the old are bearing fruit. Many a wouldbe fruit-grower interprets expectation as performance. He may read, or maybe is told, that three years make a vineyard; seven, an orchard,- -and truly, but not a self-supporting orchard or vineyard. Seven years for the vineyard; six for the peach orchard; ten for the prune or the cherry, yes, fifteen; then tree and vine are fully at home and at work; each has formed its associations and bears plentifully. The inexperienced fruit-grower must live while orchards and vineyards are growing into productivity. These are the waiting, the trying years, when expenses mount high and income falls low,- - unless your old orchards and vineyards are bearing the burden and heat of the day. It is the bearing, not the merely growing plant that makes the fruit-farm. $\mathrm{He}$ is a wise manager who has both. One hand washes the other; the old vineyard buys the new one. You will not mortgage the old in order to plant the new. You will more wisely perfect the old in order to have the new; you will intensify your cultivation of the old in order to bring the new into being.

Fruit-farming is becoming so exact a vocation, things new quickly become old. Neither orchard nor vineyard is planted or cared for as a generation 
ago. On land worth from four hundred dollars to one thousand dollars an acre we cannot afford to make mistakes, -in selection of variety, in planting, in trimming, in spraying, in soil-making, in cultivation, whatever the detail. On most fruit-farms,- - once grain or stock farms,- which may be called "converted farms," the orchard or the vineyard is planted as we would not plant it to-day. Usually trees, vines are set too close together; varieties are poor, ill-adapted to climate or soil or market, and neither orchard nor vineyard has had the right care. The soil has been depleted; the vitality of the plant is sub-normal and we must rehabilitate the trees and vines. This may be possible and may be done if truly economical. But one must carefully count the cost. Can he afford to let the ground, with all its possibilities, remain as now occupied, or should he clean it off and start anew? The practical fruitgrower alone can answer this. My own experience is that we cannot afford to let the land do less than its best. Practically it is a question of living; the fruit-grower's living. Can he afford to have his land in the most appropriate and therefore the most profitable fruit? On expensive land one must raise a relatively profitable crop, and on cheap land one can afford to raise no other. Three, five, seven, ten years quickly pass. The golden rule, the supreme rule of the fruit-farm is, "Do what ought to be done at the proper time." If you are young, you have the credit of youth,- 
and its chief asset is time. If you also have capital, you have two credits. Use your credit, it is your capital. Better use your credit than lose time in planting orchard or vineyard, or in attempting to nurse a worn-out vineyard or orchard back to health and productivity. Possibly it may be done, but so rarely, and with such cost of labor and time, that a wholly new deal is preferable. It is time that makes the Tree, and Time and the tree make the fruit-farm. Better tear out unprofitable varieties and plant profitable ones than to suffer the years to pass and your fruit-farm become mere vines and shade trees. The annual labor bills are as high for poor varieties as for good ones.

It costs more to run an unprofitable than a profitable orchard. Time works for you or against you with equal vigor. Your fruit-farm is deteriorating, your neighbor's is improving,-and at the same time. I have never heard of the fruitfarmer who got ahead of his varieties, but I have heard of varieties that forced the fruit-farmer behind. A Concord grape is preferable to a score, yes, to a dozen score of other varieties for the Lake Shore Valley. In other valleys conditions may be different. We must farm with conditions, not against them. A Montmorenci cherry is preferable to an Early Richmond, yet we may hesitate to cut down bearing Richmonds and set in Montmorenci; but we need not set out the objectionable variety, and if our orchards are yet young, we may well afford to supplant the defective with the profit- 
able tree. Gradually the wise fruit-grower works his entire farm over into only the best varieties, the most profitable kinds for his farm. A fruitfarm cannot be made in a day, though it may be seriously injured in less time. Every experienced orchardist or vineyardist sooner or later has had to face the problem of remaking his fruit-farm. The vineyards planted a generation ago are poor in variety; the rows are too close to permit use of modern tools and, notably, entrance of the sprayer. The expense of working this old-fashioned part of the plantation is out of all proportion to the returns from it. What shall he do? If he does the right thing he will make a clean sweep of the old vines and set the vineyard entirely new. Within five years he will have received profits more than sufficient to compensate him for temporary loss, and his new vineyard will serve him his lifetime. The old vineyard could become only worse as the years pass. Clearly the ledger account shows what should be done in such a case. Likewise with an orchard. Old, dying, neglected trees of poor variety cumber the ground. Cut them down; root out the stumps; plow deep; set new stock. Even though you may not gather fruit from your new orchard, it is a new orchard; it improves the value of your farm. As an asset, you have the new orchard even if it may not bear for several years. The purchaser prefers to buy a new orchard to an old and unprofitable one. And doubtless you will be the owner when the trees begin to 
bear. A fruit-farm is quite like a railroad. Roadway and rolling-stock must be of the best and must be kept up with the times, or accidents multiply, dividends fail, the line goes into bankruptcy. The fruit-farm must be kept at highest efficiency; no other condition is worth having. On the stern basis of profit and loss the best conditions are the most profitable, cost as they must.

While all this is going on, associations are forming; rooting deeper than tree or vine; rising higher than leaf or fruit. Your fruit-plantations become part of yourself; the woof and web of your thinking; the background of your memories; the scene of your activity. And the children have grown up with you and the vines and trees. But of children one must speak conditionally: they did not make the fruit-farm and their associations are not yours. The farm has been your education, not theirs. Each generation thinks its own thoughts and your posterity will not, cannot see themselves in vineyards and orchards as you see yourself. In a mysterious sense each lives unto himself. You cannot live your child's life any more than could your father live your life. True, you have ancestral memories, but they seem, after all, of another world, not of yours.

What then becomes of the fruit-farm? Usually it passes to strangers, just as it came to you. They must repeat the story: build associations, enjoy for a season, and pass the opportunity on to strangers. It is ever the case of Time and the 
Tree. They who plant orchards and eat the fruit of them think of them as a man thinks of his own children,- - more tenderly than of other children. Your children cannot know your association with the tree because they did not plant it. Now and then we meet a man or a woman-usually a bachelor or a maid-who, in lack of other lovables, cherishes the farm because of ancestral associations. This differs from the pride which flourishes on genealogical trees. That your ancestors came over on the Mayflower is a matter of pride, but that these orchards and vineyards were your father's before you, or that you planted them yourself, gives a different sense of association. It is possible for you to have feelings with your parents or for their work, but sympathy, in this sense, is impossible between you and any Puritan on the Mayflower. You may as easily establish sympathies with your ancestors of the third century. Time and the Tree form associations but not longer than two generations. A man is proud that his farm belonged to his great-grandfather because this points to family dignity and stability, but he can have no lively associations further back than his parents.

As the years pass, our associations become more tender, our plantation more productive: a curious commingling of sentiment and potatoes. The lively sense of possession always kindles the faculty of appreciation. What man, past middle life, sitting on his porch and casting his eyes over 
vineyard and orchard which have witnessed his activities, will not reminisce, reciting the changes in his day. "When I came here-" he will begin, and narrate at length the transformation he wrought till you wonder whether this now prolific center, humming with modern life, can possibly, within one short span of life, have been the wild he pictures. But we all do fade as a leaf, and the leaves fall every year.

To the young this transformation is only a tale that is told. I have heard old settlers tell of bear and deer, of elk and wolves abounding in the Valley; of wandering Indians; of itinerant preachers; of journeys in saddle; of dollars rarer than are diamonds now; of pewter dishes and wooden spoons; of linsey-woolsey clothes; of hand-looms, and corn planted between the stumps of the new clearing. Could these pioneers return they would be unhappy. They would miss this ancient world; they would miss the hand-looms and the saddlehorses; the pewter plates and the bowls of mush and milk; they would miss the venison, and the sermons two hours long; the primeval forest, the vines, the flowers, the meager fruits of their day. Sufficient unto the day is the happiness thereof. We would not be happy in their shoes, nor they in ours. Their associations could not be ours, nor ours theirs. Neither can ours be our children's. Each generation must form its own, for it can enjoy no other.

We cannot then expect our children to think of our fruit-farm as do we. We have made it our 
home; it is only the nest for the children; and the young birds do not know the value of the old nest; they seek their own. Can our fruit-farm become as the nest to the birds of the forest, or be home to our children as it has been home to us? The answer must be as the way of the world,-each after its kind. I have never known a man to think as highly of his father's house as of the house he builds for himself. Time and the Tree make the fruit-farm, but the tree must grow under your own hands and within your time. There are bridges which carry one generation over into another. Sometimes children and grandchildren play about the fruit-farm and a new sowing of associations is made, a new harvest gathered. From father to son; from son to grandson the fruit-farm passes, each generation like the Tree which Time grows on the place: an embodiment of associations; memories in the flesh. Doubtless as land becomes valuable in America, and the struggle for a livelihood the sharper, families will cling to the fruit-farm as a protection, an anchor to windward, a safe investment, a dependable source of a livelihood. The land of New York City has as great commercial value as all the farm land between the Mississippi and the Atlantic north of Georgia. Its value lies in its scarcity and the profitable use, largely the monopoly use, that can be made of it. Farm values are higher in America to-day than ever before, and they increase faster than population. 
The choice fruit regions of America are favored locations, few in number and of limited area. Land values within them are now higher than elsewhere in the country. They will ever be higher than other farm lands. Sometimes the bonds and stock of a corporation become so valuable that they are never in the open market. Heirs do not part with them. Fruit-farms are the favored estates in America, more favored than coal or mineral or lumber lands, for these, once exhausted, are of slight worth. Fruit-lands properly managed are inexhaustible. Cato knew this two thousand years ago and advised his countrymen to adapt the culture of their lands to the wants of the times. The history of Rome is the history of the land; so too is the history of France, of Germany, of England, Scotland, Ireland. The history of America is the history of the land, more difficult to understand because land in this country has approximated personal property in ease of transfer, -an innovation unknown in any other country. The history of the Fruit Valley is the story of its land. Climate holds the pen.

The man who has spent his life building up a fruit-farm knows that little remains at the close that existed at the beginning. The tree, the vine, the shrub, the root of to-day, is not that of a few years ago. The old has passed; the new is passing. Those hungry, thirsty cells which in earth or air are drinking in plant-food will themselves soon become plant-food. Half a ton of leaves grow on 
the apple tree this summer and every leaf falls to the ground and perishes. This ring of wood thinly protected by a coating of bark will, in a few years, be near the center of the tree. Hardly a shred of the vine we plant will exist in ten years. Posts and stakes rot away, are cast into the fire, and turn to ashes before our eyes. We scatter them over the vineyard which they once so stoutly held up to the sun. The berry bushes we planted vanished long ago. What is there here now that was here a quarter of a century ago? We have laid out new roads and alleys; we have torn down and rebuilt houses and barns. The life of the place is new. We have changed. The picture of ourself on the wall is of another man who did not think as we think now. His eyes looked out upon a different world. Yes, Time and the Tree have been busy. And these faces at the board, these bright eyes, these new beings sitting in the old seats, these children roaming, sporting under the shadows are newcomers, brought by Time and the Tree. And we turn to the ledger of the old days, the days of small things; there are hundreds of tons and thousands of bushels now. Then we thought a hundred bushels a portentous crop, and to-day not a tree on the fruit-farm of that kind!

Yet Time is never weary and the Tree is ever growing. Not only is it ever green but ever fruitful. It is a wonderful tree, very much like folks, a bundle of associations. You call the apple "Seek-no-further," but I call it the fruit-farm. 
The fruit-farm is a vast clock which marks off the seasons in bold lines, not by months and minutes but by the coming and going of blossom, fruit, and leaf. Nature has her routine, first the leaf, then the bud, then the full corn in the ear. We do not say it is July, but cherry-picking time; not October, but the time of grape harvest. So is it time to trim orchard and vineyard; to plow; to spray; to cultivate; to look over the farm tools; to apply potash; to sow the soil-crop; to harvest and market the fruit. A cherry tree is a natural timepiece and the fruit-grower goes by the tree rather than by his watch. The weather winds the farmer's clock. In all his work there is a leisurely haste and the wonder is of so prolific a crop from relatively so slight effort. He plants an orchard, feeds the soil, cares for the trees, and gathers hundreds of bushels of cherries, yet at no time was he rushing about, or seemingly in haste like the broker, the head of a corporation, or a young capitalist. And there are others who, like the Canterbury Pilgrim, seem busier than they are. The fruit-grower is busier than he seems. He has a relay of helpers: in the powers in earth and air; in chemical forces which make our planet habitable. He has only to hitch his own efforts to their wagon and he is brought in due season to the market where he would be.

When we consider how few are the food-makers in this world, we may well be astonished by the amount of food-products. Travel as you may in 
America-and it is also true in other lands-you see few people at work in the fields. Orchards, vineyards, fields of grain, of vegetables, of berries, stretch away before your eyes and not a man anywhere at work,- - perhaps one here or there resting on his hoe-handle, or hitching the team, or tinkering at a tool. Yet the vision is of orchards and vineyards and fertile fields. What might happen were the production of food intensive rather than extensive? If every rood of ground produced its full contribution under complete cultivation? Such intensification is hinted at to-day on our best fruit-farms. Why not eight tons of grapes to the acre? Five hundred bushels of cherries? Three hundred bushels of prunes? Three tons of gooseberries? One thousand baskets of peaches? It is not impossible. Only two factors are essential: man and climate. There is always risk of the enemy: untimely storms, wind, that break down the orchard and the vineyard; hail that cuts tree and vine and shrub into shreds; late frosts that kill buds and early frosts that destroy fruit; lightning that consumes rows of grapes and fruiting trees; insects that devour all green things, and fungi that suck the life from root, stalk, leaf, and fruit. The weather is freakish and has no respect for man. Between man and weather there is ever distrust, frequent war, and final surrender by him. Yet, seedtime and harvest are his security; Nature will have her own, and despite wind and weather. 
With the fruit-grower things rarely turn out as well as he hopes or so badly as he fears. No man can weigh the fruit on the vine or tell the number of bushels in the orchard. Cherries hang in countless red balls and grapes in countless purple amidst the green. Nature may know how many; we take to the scales. Who has ever heard in April of the failure of the Delaware peach crop? If my memory fails not, the farmer's crop always fails somewhere in April; I speak by the newspapers. But in the Lake Shore Valley in April and May, grapes are always to be a heavy crop; they blossom in June. In July, the crop is always "less than last year"; in August, the berries swell and color and look quite pompous; "a bumper crop," say the newspapers. In late September and through October, is the harvest. Your vineyard returns as you gave to it. No soil, no vine; no vine, no wine. Your grapes weigh up to your feeding of the soil. Nature knows her own. You starved your land and now you starve; you fed your land and now it feeds you. In the Valley, Nature keeps a strict ledger account with every acre and its owner and returns investment of care with interest, but discounts all poor farming. Feed the Concord vineyard well and every year it faithfully responds, and it is the only plant in the Valley which never fails to respond. Other plants take a year off,- - cherries, plums, peaches, apples, prunes, currants, but the Concord never takes a vacation. You can depend upon it to bear you a harvest as 

and 10. 0 .

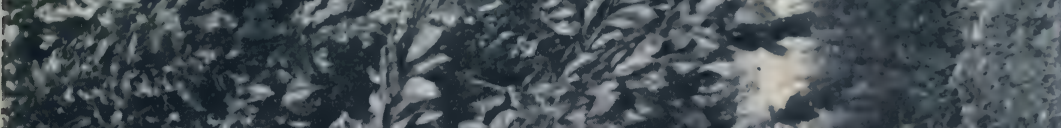

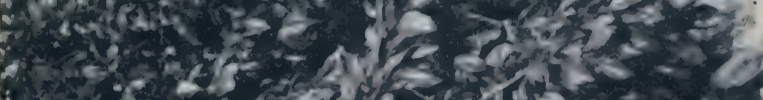
- $x^{2}-100$ and

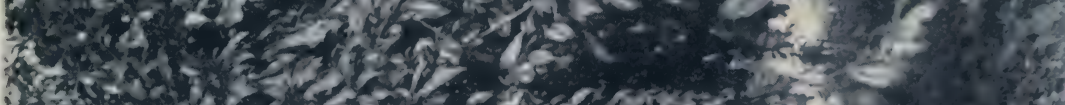

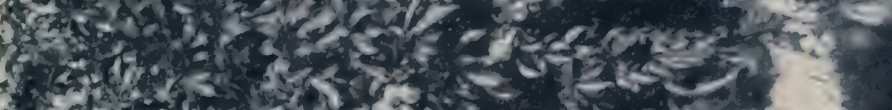

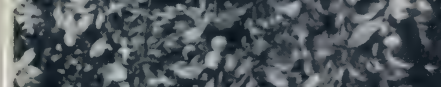

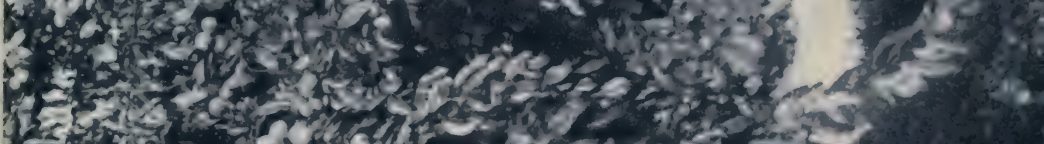

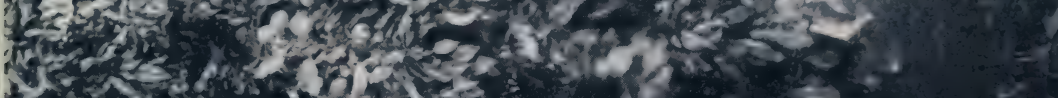

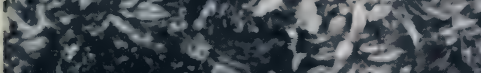

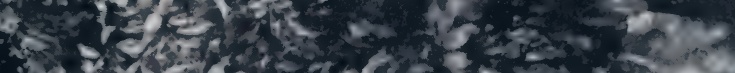

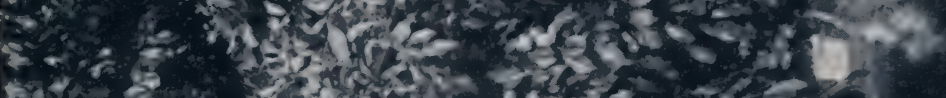

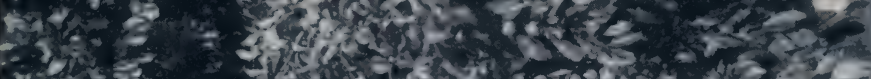

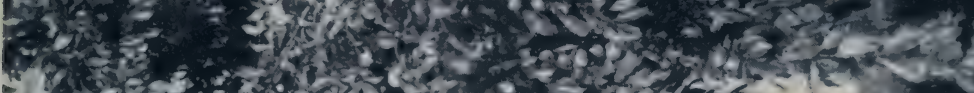

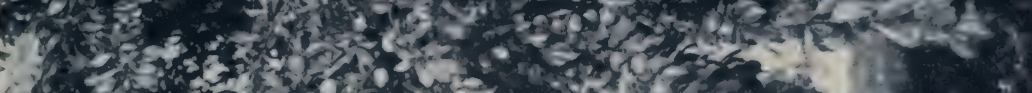

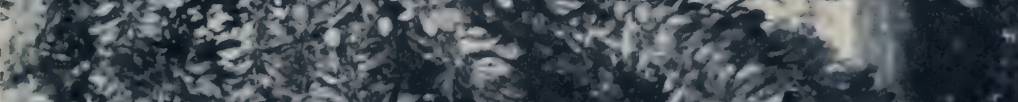

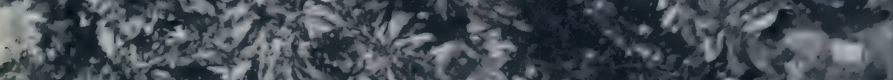

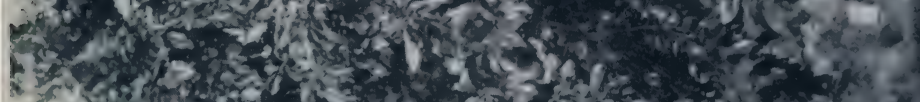

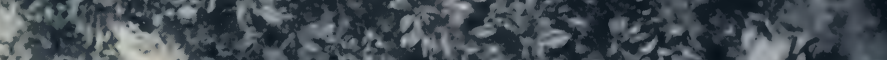

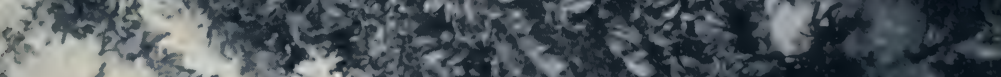
3.

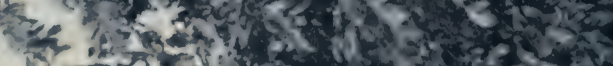

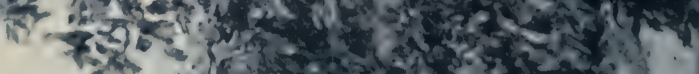

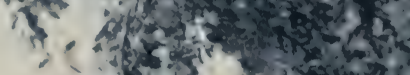

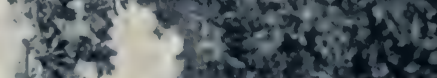

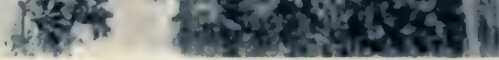



ample as your treatment of it is careful. So on your fruit-farm, the vineyard in April, July, August, October, is ever evenly, quietly, bountifully, responding to your care. It is the almanac of your life; it marks the divisions of your activities. You bank on your vineyard; you hope for your orchards. Grapes there will be,-cherries, prunes, peaches, apples, there may be. Even the acres of showy bloom may not mean cherries. Wind and rain, untimely, may wash the prospective cherrycrop to the ground. Cherries are occasional. Yet the fruit-grower may make the occasion; he may make a cherry crop every year in his soil. It is an art, but not elusive. The soil-less man has no cherries in his soil. He who puts them there in potash, phosphoric acid, nitrogen, and humus,clover, vetch, soybeans, stable manure, and drains the earth bottom and top to keep the pores open, and so sets soluble plant-food circulating through it, finds them all later in the golden fruit on the trees. And he never finds on tree or vine any fruit he has not first deposited in the ground. Here the miracle is seen: for every cherry he hides in the earth he picks many a handful on the tree. So it is quite possible that the fruit-grower banks both on his vineyard and his orchard. The chances are on his side.

Feed thy tree

And it feeds thee;

Feed thy vine

And make thy wine. 
Way back in the Middle Ages men sang this little verse,- - and it was made in Germany. Some have learned it in America. Every fruit-grower should learn it by heart and frame it in orchard and vineyard. It looks very pretty on the face of the farmer's clock. It is always reflected in the cheery face of the successful fruit-grower. I know would-be fruit-growers who have never learned it; never practiced it. They demand "bumper crops" every year of orchard and vineyard and curse the barren trees because they do not give something for nothing. By and by their fruit-farms are for sale. Sometimes the sheriff wants the farm so badly he takes it. Then the late owner will tell you how to raise fruit, much as the man whose horse has been stolen tells you how to lock the barn. "It is better," says Cato, "to buy from a man who has farmed successfully and built well." And again: "When you inspect the farm, look to see how many wine-presses and storage vats there are; where there are none of these, you can judge what the harvest is. Know that with a farm, as with a man, however productive it may be, if it has the spending habit, not much will be left over."

Feed the land at the right time; care for it in season and you will harvest in season. It seems a simple rule, yet its simplicity is its difficulty. The unselfish man begins with his land: "I feed you; you feed me"; this is his working formula. Something for something, but never something for 
nothing. Nature abhors a vacuum because she cannot fill it. If you dig a gulf you must raise a mountain. If you gather potash in eight-pound baskets, during the grape harvest, you must deposit potash long before harvest. "What!" you exclaim, "a ton of potash! $\$ 47.83$ buried in the earth! Ruination! I cannot afford it! There is nothing in horticulture at that rate!" Now we know that two tons of grapes contain thirty-nine pounds of potash, eleven pounds of phosphoric acid, and thirty-two pounds of nitrogen; and that most of the crop is water. If we have picked a hundred pounds of potash from the soil we certainly should return a like amount, and well can we afford to. Doubtless there was potash in the soil unavailable as plant-food; we must keep up the supply. It is only the available potash that feeds the grapes. "The great doctrine of availability," which Webster remarked, with bitterness, was exemplified in the nomination of General Taylor for the presidency and which worked his triumphant election, is also exemplified in grapes and cherries and all other fruits. You can have them if you make your plant-food supply available. This is the ancient game and play of fruit-growing. You do not put a ton of food into the acre of orchard or vineyard, yet the crop consumes many tons. You gather, say, four tons of grapes or eight tons of cherries to the acre. You scatter perhaps half a ton of fertilizer and plow in a clover crop. Nature returns you fruit of greater weight than 
that of the plant-food you have deposited,-and she ever will, howsoever much plant-food you deposit. She always keeps a reserve; she is looking out for her own rainy days. She must always have something in the treasury. Earth and air help you; the laboratory of the soil turns out more than you put into the crucible. It reminds one of the transformation of natural gas into gasoline, yet natural gas contains no gasoline. Surely the mystery of fruit-growing is bewildering. Yet, were you to hold back your pinch of potash or wisp of straw, your land would not feed pounds of potash, of nitrogen, of phosphoric acid, and of straw to your trees and vines.

It seems then, that Nature helps the fruit-grower who helps himself. "With me you prosper; without me," she says, "you perish." Some men, considered by the world to possess monumental generosity, say to the charity: "Raise a dollar and I will give you fifty cents"; or, if desperately generous, they say: "Raise a dollar and I will give you another." Then the campaign opens and nobody has any peace; and the giver of the second dollar insists that the college shall be named after him. To the fruit-grower Nature says: "Give the soil a spoonful of plant-food and I will give a ton." Nature is forgotten and the fruit-grower has the tree named after him. And this is going on all the time. Scratch the earth and it yields a cherry; feed it and it yields tons of cherries.

At whatever angle we approach the fruit-farm 
we sooner or later arrive at the center-the soil. Tell me the soil and I will describe its owner. It is his alter ego. Dust we are and back to dust we go, and while we live we are keepers of the dust. Yet all do not seem to know this. May we not assume that as soon as there was opportunity for soil on the earth man appeared? He is the only animal that makes soil and deliberately gets his living from it. Not only does he look before and after, he is the soil-maker. If you will but weigh this against his other creations, you will discover that it is his most important contribution to his own civilization. "Oh that mine enemy would write a book!" exclaims the hungry critic. "Oh that my friend would transform land into soil!" exclaims the hungry man. The high cost of living means the low production of soil.

But the earth has its seasons like the sky, and the laboratory of the soil is more active at some seasons than at others. I once knew a farmer who planted corn while sitting in slippers, in a rockingchair, on the porch, reading the New York Evangelist. He did not get enough from his cornfield to renew his subscription to the paper. Another farmer I knew raised record crops of corn and could not read or write. The ancient Lake-Dwellers, on Lake Geneva, raised wheat. I have seen their wheat,-black, oxidized grains sealed in a bottle in the De Candolle Collection; but the Lacustrines sang their songs like Homer; they never bothered themselves with reading or writing. They raised 
wheat. One of the startling revelations to the graduate of the agricultural college, and of colleges in general, is the big crop which the man of the diploma does not raise and the steady crop the unlettered fruit-grower always raises. This does not count against the college but for the unlettered farmer. He reads books in grapevines, sermons in cherry stones, and crops in everything. $\mathrm{He}$ cannot give scientific names to root-worm or brown-rot, but he can exterminate them by spraying at the right moment. He never thinks of the chemical properties of the soil beneath his feet, but it is as loose as ashes and filled with humus. His regular and heavy harvests tempt you to disparage his college-bred neighbor who takes samples of the earth, fills bottles with queer liquids, makes tests, and tells you that the land lacks nitrogen. "Too much sorrel," remarks the unlettered neighbor. "The land is sour; sow clover, soybeans, or, best of all, cover it deep with barnyard manure. That is what is the matter with your land." Both tell the truth, and each by his own tests and through his own formula. Shall we dispraise either fruitgrower, him who knows the chemistry of the land or him who knows the meaning of sorrel? Each acts up to his knowledge and sorrel was growing before chemical laboratories were endowed. Practically, one is as wise as the other. But there is a difference. The fruit-grower, who also is a soil-chemist, saves, conserves time. Knowledge is a short-cut to the flour barrel, as well as a 
dangerous thing. The Swiss Lacustrines raised wheat four thousand years ago, but less to the acre than does the wheat-farmer of to-day. Knowledge outlined at agricultural colleges is not unlike prepared food; it has the ingredients of nutriment. But we prefer ordinary meat and drink. For extraordinary service, for much labor in brief time, for the weariness and exhaustion of great risks, and for carrying capacity cut down to lowest terms, as when reaching the Poles, or marching against the enemy,-concentrated food has its uses.

It is every man's experience that he must know his machine, his task, his labor, in order to utilize the scientific conclusions duly worked out in his own vocation. The fruit-grower must know his own land, his own soil-its composition, vitality, productivity. Fruit-instinct is a pearl of great price. The best horseman has best horse-sense and the word has become the world's metaphor. Fruit instinct is not given with diplomas at agricultural colleges. As Webster said of eloquence: "It cannot be brought from far; it exists in the man and in the occasion." The fruit-grower with fruit-instinct can raise fruit despite agricultural college, or experimental station, just as the man with the scholar's instinct may become learned despite Harvard or Wisconsin. There is a substitute for instinct and that is knowledge; it is not instinct. They differ. A farmer by instinct will always raise more cherries to the acre than will the 
farmer by mere knowledge. It is instinct that keeps the race on the planet,- - not new knowledge. But as the agricultural college cannot make a fruit-grower, no more can the medical school make a doctor, the law school a lawyer, or the engineering school an engineer. It is the man himself, not the school. The diploma is only a certificate that he passed the college way. But knowledge must be the capital and resource of most men; the genius among farmers is rare. Luther Burbank is unique, but he can set thousands of lesser men to work improving varieties: to produce paper-shell and other walnuts; to improve oats, wheat, and barley; to reclaim the deserts with cactus; to improve flax, hemp, and cotton; to increase the yield of clover, timothy, and alfalfa; to improve peas, beans, and tomatoes; to add even a better potato than the Burbank; to better all kinds of berries; to improve grapes; to work out perfect plums, apples, prunes, without seeds; to make quinces delicious raw and to double the productiveness of the cherry; to improve the pear,-in brief, he can tell posterity how to apply his methods and discoveries and thus to increase immeasurably the world's supply of food. Men by knowledge can learn to carry on what he began with instinct. The agricultural college, like any other training school, helps plain people learn how to make a living. There is only one kind of scientific work. There is only one scientific method in fruit-farming. There are different approaches to this method. 
It is therefore a question whether the would-be fruit-grower will turn out a fruit-grower, or only a medium through whom the title to the land is transferred to some man who is a fruit-grower by instinct. The "natural farmer" shines like the "natural painter," the "natural musician," even the "natural doctor," or the "natural engineer." Nature fits most men for something, but not always for fruit-farming. Almost any man believes that he can do light farming; that if he had only a well equipped fruit-farm he could "get along nicely" and even run the risk of getting rich. Nature in due time-very infrequently, and but once-produces her Raffael, her Beethoven, her Shakespeare, her Angelo. It is the fashion of the world to praise the ornamental, the luxurious, and to overlook the practical and the necessary. "Arms and the man, I sing"; "Achilles' wrath I sing,"-so open FEneid and Iliad. War, passion, beauty, statecraft, crime, wickedness,- - not fruit-farming, are the subjects of the story. Cato, it is true, more than twenty centuries ago wrote on Farm Management, but it is not literature as is the Germany or the Agricola of Tacitus. The Eclogues of Virgil are of the oldest literature of farming, but they dwell on the passions of men, not on cherries or corn. It is hard to make poetry out of a quart of berries save by assimilation, and that is not poetry but chemistry. Perhaps our units of measure of things and men need revision. Virgil, first to put the peasant into literature, 
makes him a churl, a slave. Shakespeare's farmers are all boors, the butt of ridicule, as are his laborers of any calling. Only in the modern novel of "real life" is the farmer the hero of the story. Adam Bede has a soul as well as a jack-plane, and passions quite as picturesque as Scott's Antiquary. But the farmer has at last got into literature, and has come to stay. American life has compelled recognition of his rights and privileges as a man. Democracy runs to farmers as theocracy to priests. Ours began as a nation of farmers.

"By the low bridge that arched the flood, Their flags to April's breeze unfurled; Here the embattled farmers stood And fired the shot heard round the world."

The arrow-maker, the sword-maker, the maker of the war-harness, the gun-maker, the shipbuilder, the money-maker,-why not the foodmaker? No Virgil or Shakespeare hereafter will make the farmer the boor and butt of his story. Indeed the echoes of Mantua and Abbotsford now print themselves in taking-titles of new novels which bring swiftly to mind green orchard boughs, sweeping vines, purpling fruit, and the stress and storm of life on the farm. This life is made the foil to the life of the city, that we may know the commonplace of commonplaces: whether in the bank, in the White House, or on the farm, human nature is quite the same. A man's a man whether under an apple tree or over the roof of a sky- 
scraper. So in latter days, literature has discovered the fruit-farmer: all in due time. In the almanac of letters the fruit-grower has his date. Some people will discover mere respectability in all this; finding it in a book, they will believe it. This discovery is merely their own. The fruitgrower is a man with a special instinct. Napoleon was an excellent farmer but took too much time for military exercises. Yet his farm-Franceis a better farm because of his farming. He exhausted the French, but not France.

Washington was a farmer, and though much absent from his plantation, on military excursions, he neither exhausted the Americans nor Mount Vernon. And we know that he preferred his farm to the presidency. I have long considered him the greatest of Americans, and much of his greatness was due to his instinct for farming. Cincinnatus, in the old Roman story, owed all his fame to his reputation as a farmer. Jefferson too, was a farmer, and has recorded his conclusions in one of the most famous of books, his Notes on Virginia:

Those who labour in the earth are the chosen people of God, if ever He had a chosen people, whose breasts he has made his peculiar deposit for substantial and genuine virtue. It is the focus in which he keeps alive that sacred fire, which otherwise might escape from the face of the earth. Corruption of morals in the mass of cultivators is a phenomenon of which no age nor nation has furnished an example. It is the mark set on those, who, not looking up to heaven, to their own soil and industry, as does the hus- 
bandman, for their subsistence, depend for it on the casualties and caprices of customers. Dependence begets subservience and venality, suffocates the germ of virtue, and prepares fit tools for the designs of ambition. This, the natural progress and consequence of the arts, has sometimes perhaps been retarded by accidental circumstances: but, generally speaking, the proportion which the aggregate of the other classes of citizens bears in any state to that of its husbandmen, is the proportion of its unsound to its healthy parts, and is a good enough barometer whereby to measure its degree of corruption. . . . The mobs of great cities add just so much to the support of pure government as sores do to the strength of the human body. It is the manners and spirit of a people which preserve a republic in vigour. ${ }^{x}$

In our day, as in other days, in all countries, at all times, men love to get back to the land. This points to their natural avocation; circumstances have made them senators, judges, lawyers, manufacturers, railroad-men, writers, doctors, seacaptains, bankers, and so on through the weary list. Many a good fruit-grower has been spoiled in the lawyer, the doctor, the merchant. Happy is the man who is doing what he is best qualified to do, particularly if he is by instinct a fruitgrower and grows fruit. In our day the world is reaching this conclusion. Young men are looking to fruit-raising as a vocation, as they look to other vocations. Like banking, railroading, mining, practicing law or medicine, or engineering, fruit

${ }^{x}$ Notes on the State of Virginia. Written by Thomas Jefferson. Philadelphia, Printed and Sold by Prichard and Hall, in Market Street, Between Front and Second Streets, M.DCC.LXXXVIII. Query XIX. p. 175 . 


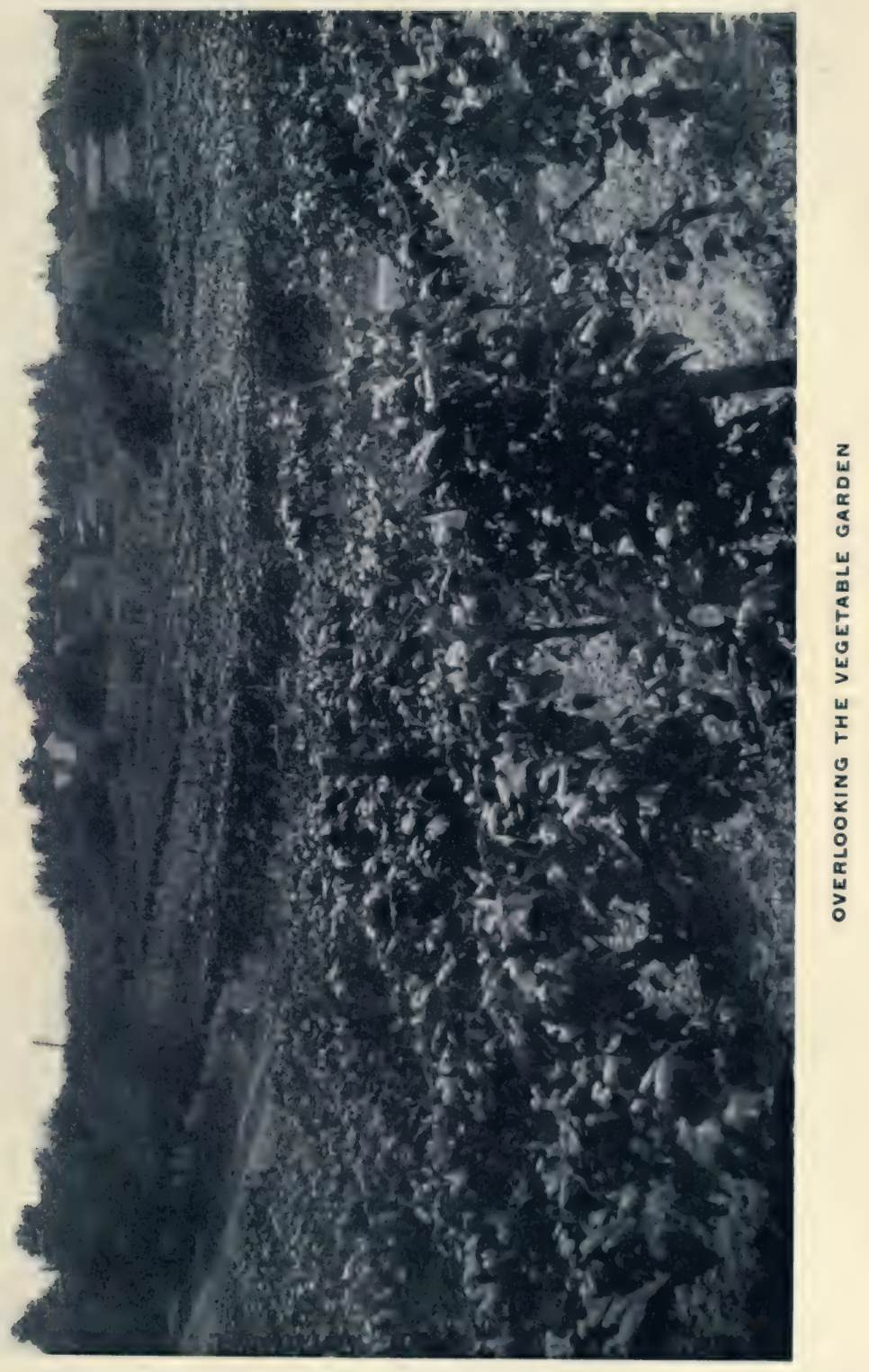



land is an opportunity. It is not merely that fruit-raising may be commercially profitable but that it is a business worthy a man's best services. In other words, there is a career in fruit-raising as in war or mining, in printing, publishing, or manufacturing. Fashion governs the world and fruit-farming is in fashion. It is not a disgrace to raise potatoes, or cherries, peaches, or grapes. Is it a disgrace to raise puppies, or kittens, or triple-combed roosters? Yet a cattery is not precisely like a fruit-farm.

In Cato's time every senator owned a huge piece of Italy. Landownership meant aristocracy, and to this day the landlord is the master among men. Every nation, at some time, gets land-hungry and it is land-hunger that keeps the world a military camp. I know that there is a vociferous part of mankind that calls property robbery and landownership tyranny. Therefore, it says, "Own no land." The more people the less land, yet the land is no less. This inverse ratio of land and people partly explains its appreciation. And as fruit-lands are limited in extent and are uncommon, such lands are most prized of all. These lands are clocks on the earth's surface, marking time. The fruit-grower knows his time-piece and so regulates his activities. He never winds the clock; it is a perpetual self-winding time-piece. It tells him when to plant and when to cultivate; when to trim and when to gather the harvest. What farmer ever carries a watch, save to a wedding, a 
funeral, or to meeting! He can farm a lifetime without one. In the Valley, the lake breeze tells when it is four o'clock afternoon, and the clover also marks the hour. No less precise are the shifting of the air-currents at nine in the evening; at three in the morning. The cherry tree is a dial, and the moving shadow of the grape-vine marks off the hours. But these are the finessing of the clock; there are the great divisions of the seasons. Winter begins when the leaves fall and ceases when again they start. Spring begins with the call of the soil and ends with the setting of the fruit on vine and tree. Summer begins with the growing grapes and cherries and ends as they ripen; and autumn-briefest of seasons-slips in between the purpling fruit and the leaves rustling at your feet. All in due season.

And then, there is within the man a mysterious interpreter of the seasons,- that instinct which moves him to do and do. By that subtle power he reads the clouds in the sky; the invisible winds; the rising and setting of sun, moon, and stars, and the shades and colors on the living earth. It tells him when to plow and to sow; when to cultivate and to harvest; and in following it he does all things in season.

In planning the fruit-farm we must remember the days. Strawberries ripen in June; grapes and prunes in October. As the fruit-farm is a cycle of the seasons, each arc of the cycle may register its fruit. With care we may have a succession of 
fruits quite through the year. The links of this fruit-chain are strawberries, cherries, raspberries, dewberries, blackberries, plums, apples, peaches, grapes, nuts, and the gifts of the garden, between: radishes, salads, peas, beans, onions, beets, potatoes, corn, okra, egg-plant,- each in succulent varieties. One must live, and he may live well, on the fruit-farm. The table may have fresh fruit the year round if one will but take the trouble to secure it. Few fruit-growers take the trouble. If the housewife is also fruit-grower, helper in orchard, berry-field, and vineyard, she will prove to you that you cannot pick cherries and make cherry pies at the same time. But if the labor supply is thriftily used, cherries will be picked and pies will be made. Nearly every fruit may be kept sound for a time in cold storage, and kept indefinitely, provided it is dried, pickled, or canned. Much of this art and mystery lies on the distaff side of the house. Apples, prunes, and grapes will keep long: the apples, unbruised, in barrels, if kept cool; the prunes, sound, in shallow boxes, cool and dry; the grapes, unbroken, in dry sawdust, such as is used in packing California grapes. Set these treasures in a room tempered all the time just above freezing, and they will keep themselves for half the year. Garden produce as all bulbs, tubers, and roots, keep best in cool, dry sand, above freezing, but no fruit will keep (save airtight) beyond the season when its kind again is forming. Evidently fruit preservation is a prob- 
lem of temperature and exclusion of air, and I may add, of light. The fruit-cellar therefore becomes a conserver of supplies: it is a clean, airy, cool, ventilated, dry room, usually below ground. It is not an ice-house. The great clock of Nature marks off the farmer's time: to do and what to do. Neither too early nor too late, but in season is the law of the fruit-farm. Nature hates to be nagged and refuses to make up anybody's lost time. There is a tide in the affairs of the fruit-farm which leads on to fortune. It must be taken at the flood. No man can run a fruit-farm on an ebbing tide. Nature gives man and beast, plants, and all living things their food in due season; but she has no supplementary hours; no extra seasons; she is reduced to the lowest terms. Instinct tells the fruit-farmer all this. Some fruit-farmers learn it as a task of the day. But whether by instinct or by knowledge, the farmer knows his clock, though he never winds it; and though he can not set the hands backward or forward, he can move precisely with them. 
CLIMATE and location determine the value of the farm. In selecting the site, we must consider climate first, for we are prisoners of climate. It is climate that determines what seeds shall grow and what shall not. Farming is only one of the uses man makes of climate. It is because of climate that the earth brings forth fruit after its kind. Location means convenience, and the most convenient use of climate is the most convenient use of the land. Yet all land is not equally convenient for use. The man himself must know. He contributes to the conclusion of the whole matter, for his decision in choosing a climate determines his future. There are climatic belts, or regions, each having possibilities and limitations. Man cannot change these. The kind of farming possible depends upon climate; therefore one must go to the proper region for fruit-land, grain-land, or grazing-land. True, tropical fruits may be made to grow in hothouses; man may supply the climate after the fashion of things artificial; but we do not look for orange 
groves amidst snow-banks. The supreme law in farming is adaptation. Perfect adaptation means perfect farming, and degrees of adaptation shade off into utter failure. The farm is largely man-made; it cannot be said to be wholly natural. Indeed, the most productive farms are adaptations which illustrate man's farthest departure from the wild. Such adaptation, for human ends, exemplifies the best use of climate. Thus a ranch in the Lake Erie Valley, or a vineyard among the Idaho mountains is not an example of the nice adaptation of climate to human wants. The sun settled this matter ages ago.

Usually, in seeking a farm, a man is dominated by his associations. Nearness to the old home, to friends, to city or town, determines his choice rather than the suitableness of the land itself to the uses he purposes to make of it. The idea is common that any land will raise anything possible within the zone in which it lies. Thus most people believe that oranges and cocoanuts grow in strings along the equator, and apples anywhere in the temperate zone. Yet we are assured that all grains and fruits, all roots and leaves and stalks, used by man as food, thrive best close to the northern, or southern, limit of climatic production, like oranges in Jaffa, Florida, and California, and wheat in British America. If a man would raise any farm product in perfection, he must select his farm within the climatic belt adapted to such production. This means specialization in 
farming on a grand scale. In a general way every man considers climate when he deliberately locates his home. He thinks at least of the extremes of heat and cold, of drouth and rainfall, of sunshine and cloud. His instincts guide him. He inherits from his kind the experience of the ages; from cavedweller and lake-dweller, from the man of the Stone Age, of the Bronze Age, and of the Iron Age,from that innumerable throng of men and women who have filed across the earth from the beginning, bequeathing to him experiences of long ago which yet dominate our lives. Most serious of experiences is of the art of making a living. So man considers wind and weather when he seeks a home. In a rude way he avoids total failure, for wind and weather drive him into a corner in which he can eke out existence. If climate be not too unfavorable, he concludes that he has made a good choice. At least he proceeds to farm his land.

But most men come into possession of a farm without being consulted about the climate. Each thus receives a tool as a gift and continues to handle it as did his fathers before him. So near is he to wind and weather; so close a prisoner of climate is he, life with him is static; he gives climate no serious thought, save to grumble at the biting frost, the scorching heat, the engulfing rain. Who has not witnessed the transformation of a region from grain to fruit; from potato fields to truck gardens? The thoughtless farmer is ignorant of his own sky and tries to raise wheat when he 
should be growing peaches; grapes, when he should sow his fields to buckwheat. It is the old story of the round farm in the square hole; of meadows in Florida and orange groves in Vermont.

Within any climatic belt, the chief problem for the farmer to solve is the selection of the site for his farm. This means, primarily, convenience. A well-located farm is like a corner lot on Broadway. Remembering always that land unadapted to farming cannot be made farm land by mere location, of two farms the better located is the more valuable. Everybody desires convenient land,- - that is, land most accessible for making a living. Good roads shorten the distance to market and cut down the cost of farm administration. The test is transportation. A farm many miles from the city but connected by good transportation is nearer the city than another lying quite close yet inaccessible. Location determines the cost of farming. Land remote from markets, though producing heavy crops, eats itself up in transportation; the farmer is attempting the impossible. He may starve amidst plenty. Poorer land well located is worth more than choicer land badly located. The best farms being best located always command the highest price; they cost most and pay best.

Climate is the constant factor in farming; the value of location varies with world conditions. Every inch of American soil was once out of relation to the world-market. Much of it is now in relation to that market and lands are ever coming 
into favorable location. The larger currents of world events, the smaller American currents, affect land values. Within fifty years the wheat region in America has shifted from the Middle States to the Western, centering about Illinois, and again northward, across Minnesota, into Canada and British America. The potato belt has removed from the latitude of Boston and Chicago to that of northern Maine; the cotton belt, from the Sea Islands of the Carolinas to the coast of Texas. Truck-farming is more profitable in Florida than on Long Island. Nature, that is, climate, makes this possible. Transportation solves the problem. Every market town in America is now close to the fruit-lands of California, the cotton fields of Texas, the truck-farms of Florida, the vineyards of Chautauqua and the Lake Erie Valley, the potato fields of Maine, the berry fields of New Jersey, the tobacco fields of Virginia and the Carolinas. Though we commonly think in terms of our political geography, our real geography is economic,-a geography of lines of trade and travel, of railroads and steamship lines. The real distances in America are best learned in the market place.

Lines of trade and travel, general and local, determine the value of location, and by such lines must be understood the available ones. A through railroad may traverse a farm, yet the farm itself may be practically many miles from a railroad. It is the most accessible farm land that is most 
valuable for farming. Most purchasers must be content with "second best" land,-with the less or even the least valuable location. One must come first, or command equivalent resources, would he have the pick of the land. Every farm has its price, and youth and cash are the best credit. Land best located is a permanent asset and may be sold at any time with slight risk of loss. In ease and opportunity of transfer such land resembles the most valuable personal property, such as jewels and the precious metals. He who owns the farm everybody wants owns the best farm. The best located farm is, economically, the most productive. Primacy of location is the supreme advantage. Only the wise man discovers this. He recognizes the possibilities of the site; he foresees favoring changes,-markets, roads, trade, commerce, associations.

Or, indifferent to conveniences, the investor ignores all demands save his own, subordinates himself as a world-producer and selects a site exclusively pleasing to himself. He deliberately cuts himself off from relations which the world at large demands. He locates in isolation, apart, by himself, remote from men; beyond the whistle of steamer or train; beyond trolleys and even beyond automobiles. He builds a retreat, a little world of his own. His site, however delightful to him, cannot be called other than exceptional. Few shall ever desire it; it is not a commercial article. His is the exception, not the rule, in locating a farm. 
His isolation is in these days artificial. The world to-day lives in, by, and through its relationships. He ignores them. In this he consults his own mind. He pays the price of isolation precisely as another, who has primacy of location for every convenience, pays the price of his primacy. A home in the woods, remote from the haunts of men, has its price, and to many, a prohibitive price, just as to many, corner lots on Broadway and best located farms have a prohibitive price. So, after all, valuation depends upon the man. In him we come to the inconstant quantity. His tastes, ideas, whims, theories, notions, desires, passions, determine for him the value of any land. His selection of a site is determined by his racial instincts, his age, his education, his temperament, his previous associations. If his motive be wholly to buy and sell, his choice differs from that of him who yields to sentiments of association. Men at some time turn to the scenes of their childhood and youth. Many never remove from these scenes. Some select a farm within a region with which they are familiar because there they feel at home and know how to proceed. In other words, these have most courage when on their native heath. But thus to yield to sentiment may be to ignore the laws of climate and location.

Very few men proceed, as one may say, scientifically in the selection of a farm. New Zealand may, scientifically, be preferable to a township in Pennsylvania, but you locate in the township 
without for a moment weighing the superior opportunities of New Zealand. Indeed, the instances of scientific procedure in locating farm lands are almost limited to capitalists who combine for profit in the exploitation of a region, as a Texan fruit-belt, or a wheat-belt in British Columbia; rubber fields in Central America, or guano beds on the Pacific islands.

Ordinarily the man who buys a farm buys within a region limited by his own associations. He buys land which reflects himself. The farm is a landed edition of himself. The so-called economics of farming is essentially the psychology of the farmer. He doubtless never thinks of himself as a psychologist. His mind is his farm. The psychology of farming may seem an obscure, not to say a rare and uncertain crop, though it truly includes all the labors of the farmer all the days of the year. He may miss the moon at bean-planting, but he cannot escape the psychology. Indeed, the psychology of farming is the function of which the farmer is unconscious his life long. But in selecting the site for his farm he responds to this function. No nice analysis of motives strains his mind, when, rapidly casting his eye about him, he resolves that the site suits him, or can be made to suit. He desires himself in the site and so is satisfied.

When you have decided to purchase a farm [says Cato, that rare old Roman farmer], be careful not to buy rashly; do not spare your visits and be not content with a single 
tour of inspection. The more you go, the more will the place please you, if it be worth your attention. Give heed to the appearance of the neighborhood,-a flourishing country should show its prosperity. When you go in, look about, so that, when needs be, you can find your way out. Take care that you choose a good climate, not subject to destructive storms, and a soil naturally strongin a healthy situation, where labor and cattle can be had, well watered, near a good-sized town, and either on the sea or a navigable river, or else on a good and much frequented road. Choose a place, which has not often changed ownership, one which is sold unwillingly, that has buildings in good repair. Beware that you do not rashly contemn the experience of others. It is better to buy from a man who has farmed successfully and built well. ${ }^{x}$

What motive, then, in buying a farm? To sell again and quickly, at a profit? Then you are a dealer in real estate, not a farmer. Do you buy in order to indulge in an avocation? Then it is diversion you are seeking. Would you experiment with seeds, roots, and soils? Then it is a chemical laboratory or pure science you are after. Are you timid as to stocks and bonds, shares and industrials generally. Then it is an investment you seek,- - something you may be able to find when you would take an inventory. Do you want the farm as a home-a site for yourself where land and sky, the procession of the seasons, springtime and harvest, rain, snow, hail, fungi, insects, and the pleasant anxieties of life weave their warp

x The copy of Cato on Agriculture which lies before me bears the date 1598, is the edition of John Meursum, printed at Antwerp, by Plantin. I follow the admirable translation of Fairfax Harrison. 
and woof? Then you say to yourself: "Here will I live; I have found the site on which to make my farm." Imagination translates opportunity into realization: this is the psychology of farming.

The Chautauqua fruit-belt in New York and the Lake Erie Valley in Pennsylvania extend for fifty miles parallel with the beach of the lake, beginning seven miles east of the city of Erie. This entire region is a narrow valley, not wider than six miles between the lake and the range of low hills to the southward. It is a rolling country, rising from the lake level to the crest of the hills some thirteen hundred feet. The hills are cut across by deep gulches, which begin at the crest and open northward and northwestward to the lake. The streams are swift and shallow, though in ancient times sufficient to cut chasms half a mile wide and in places three hundred feet deep. The exposure is of the earliest formations known to geology: the Silurian, the Devonian, and the Carboniferous, abounding in fossils both of plants and animals. The enormous elevation of this mass of hills gave the swift descent of waters to the lake and caused the extinction of possibly a dozen species of shellfish whose remains now compose the rocky basis of the hills, - a vast heap of shell buried amidst the stone. For ages the waters have seeped through this formation, impregnating the entire Valley with a solution of lime. In the Lake Shore Valley is the oldest land on the globe and the rocks tell 
their own story. From the crest of the hills to the edge of Lake Erie these streams cut deviously upwards of a dozen miles. The ravines disclose layers of mollusks, coral, fossil lilies, cone-in-conethat puzzling formation which awaits explanation, -and innumerable layers, in varying thicknesses of sedimentary rock. In this Valley the Garden of Eden has been located by a writer of some eminence in his day. Vestiges of inhabitants during the Stone Age abound in arrow-heads, spear-points, stone pestles and mortars, skinners, and rude pottery. The region is a fruit garden, whether or not Adam and Eve ever dignified it by their melancholy presence. The land slopes northward toward Lake Erie, and the area suited to orchard and vineyard is sharply defined by the crest of hills at the south, the lake at the north, the level plain of Ohio at the west, and the high hills of Chautauqua County to the east. It is a narrow valley containing not over three hundred square miles. Within this domain grapes, berries of all kinds, peaches, pears, apples, prunes, cherries, cereals, melons, vegetables, grow in perfection, attaining the maximum in quality and quantity. The contour of the Valley makes this possible. Fruit of any kind attains perfection at the northern limit of its production. The Valley marks this limit, for fruits that are adapted to it, in the United States. The lay of the land is favorable. It slopes towards the north, thus preventing too early start of sap, leaf, and bud in the spring. The soil is deep, as tested by borings of 
innumerable gas wells in the Valley, attaining a depth of one hundred and seventy-five feet in many places. Lake Erie tempers the weather, preventing extremes of heat and cold, making spring late and prolonging autumn till all fruits and the wood of the new growth are well ripened. The lake is part of an immense waterway, some two thousand miles long, a depression which is the natural highway for winds and storms, affording perfect ventilation of a body of air warmer than otherwise would be found in this latitude. This ventilation secures against frosts and cold and storms of all kinds, for most storms which threaten the Valley move down the lake without harm. The lake winds protect orchards and vineyards, and every field they sweep, from untimely frosts. On an early September day, the traveler who passes over the crest of hills to the south of the lake and thus emerges into the edge of the Mississippi Valley notices at once a change of temperature. He sees a region blackened by early frosts. The demarcation is sharp: on one side of the highway purpling vineyards, peach trees bending low with fruit; on the other side, cornstalks blackened by frost, and everywhere the sere and yellow leaf. It is useless to attempt to raise fruit outside the fruit line of the Lake Erie Valley. Here, almost in sight of the lake, one may raise cherry trees for shade but not one cherry will ever ripen on the tree.

Nor is this the conclusion of the matter; Nature 
protects the Lake Erie Valley with blankets of clouds from November till April, moderating the winter and thus sheltering all kinds of berries, vines, and fruit trees. The moderate snowfall is sufficient to cover the ground with this best of all winter covers. From May till November the weather is ideal, rarely attaining eighty degrees of heat, and the coldest winter day seldom shows zero weather. Within this Valley are upwards of thirty million grapevines in highest productivity; thousands of acres of berries, peaches, apples, prunes, plums, cherries, melons, corn, wheat, potatoes, peas, beans, and vegetables. The Valley was the far "West" until a few years after the close of the Revolution, when settlers began entering at the east from New England and New York, and from Philadelphia, Harrisburg, and Pittsburgh, through the west, near Erie. La Salle discovered the region in 1679 , while voyaging on the Griffon westward along the south shore of Lake Erie, accompanied by Father Hennepin, that charming romancer, and others, first of Europeans to behold this garden of the New World. Baron La Hontan, in 1688 , penetrated the region at the command of Denonville, Governor of New France; and Charlevoix, in 1720 , traversed the Valley, recording the prodigality of Nature, the abundance of wild apples, plums, grapes, the forests of nut trees, the deer, bear, elk, and buffalo on every side. It was Charlevoix who left the name "Aux Boeuf" which yet lingers in Erie County, though better known 
as French Creek. But it was not until Perry's victory in $\mathrm{I} 8 \mathrm{I} 3$,

\section{"On the tenth of September, The day we remember,"}

that the western country became indisputably American soil, and New France-the hope of the great La Salle-became at last America. For more than half a century the Valley has been traversed by one of the principal railroads of the country, giving swift transportation to the markets of the world. To-day it is teeming with population and every rood of ground supports its man. There are many fertile farming regions in America; this is but one of them. Here fruit land sells for a thousand dollars an acre and some of it produces five hundred dollars an acre. If the net return be capitalized at five per cent., the land would be worth from seven to ten thousand dollars an acre. The explanation lies wholly in the climate. Nature has made the Valley a fruit garden. She has made other regions a fruit valley, a grain field, or a truck-garden. We are wise if we take her as she is, get on her side and use climate to supply our wants. We can do no more, and most of us do less.

In selecting the site for a farm the purchaser rarely gives a thought to the geology of the region. He will discover, however, if he pursues the matter, that every fruitful farming region owes its fruitfulness, as does the Lake Shore Valley, to climate and soil, - and that is as much as saying, to its 
geology and its climate. The immense productivity of the Lake Shore Valley is due chiefly to its geology - to the lay of the land, hollowed and leveled, twisted and heaved perhaps sixty million years ago. Three hundred feet of dead shellish, a mass of dissolving lime, is a strong basis for producing fruit. Elevation, the northern slope, perfect ventilation, the protection of a vast body of fresh water, a coverlet of clouds in winter, a deep and responsive soil, and primacy of location, impart qualities which are rarely combined.

Many are the rich fruit valleys of America, each having charms of its own, but no man can describe life in all these valleys. Climate, soil, and the man are the three elements in every fruit valley. The accessories are only slightly less essential,neighborhood, markets, transportation, schools, churches, amusements, relationships with the whole world. Any fruitful valley in America might be taken as a unit of horticultural measure; comparisons make heroes of us all. If I have taken the Lake Shore Valley as a unit of measure, it is because of familiarity with that measure, not because other measures are lacking. The essentials of contentment are not on a sliding scale; ten thousand a year may not be had from fifty acres in any fruit valley. But the laws of fruitfarming apply in all fruit valleys, and whether we live in the east or the west, in the north or the south, in Pennsylvania or California, in Florida or Michigan, we must obey these laws. We must 
be careful of the type. So the three hundred square miles of the Lake Shore Valley hint at means and methods quite as significantly as do the larger or the lesser areas of other American fruit valleys.

It might seem then that farming is a profession quite as truly as law, medicine, or theology. No longer can farming be continued by mere rule of thumb; one of the oldest of occupations, it at last is becoming exact,- that is to say, scientific. There are thousands who yet do "light farming," and they have their reward. The call "back to the land" is a very worldly one because tested by all worldly tests it is profitable. If the farmer who owns the finest farm could at will turn it into an oil-field abounding with "gushers," he might not be unwilling to make the change. Many a farm has suddenly become a forest of derricks. The mere by-products of farming,-fresh air, pure water, pretty scenery, singing birds, and everchanging skies cannot, as attractions, fully explain the return to the land now for some years going on in America. It is the products of farming which bring men back to themselves and to their own. Competition in every vocation is now so fierce, farming is discovered as an open approach to sanity and comfort. If this be true now when the population of America is but one hundred millions, what will it be three generations hence when population exceeds four hundred millions? How shall they get food? The land area does not, cannot 


\section{1.}

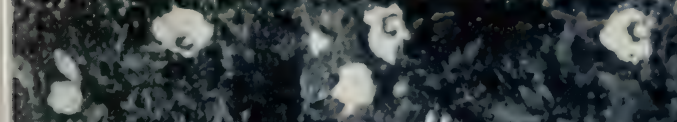

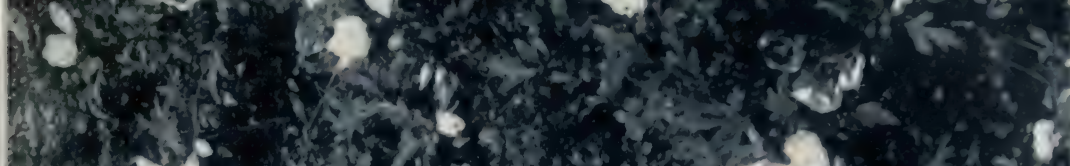

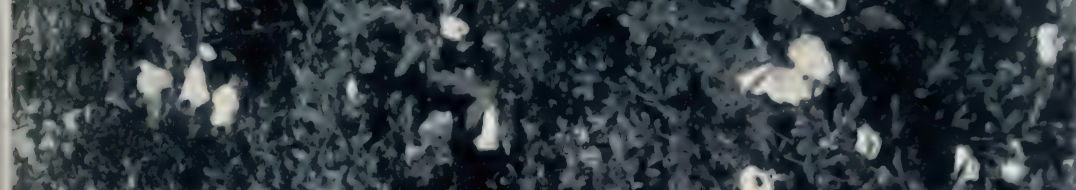
+

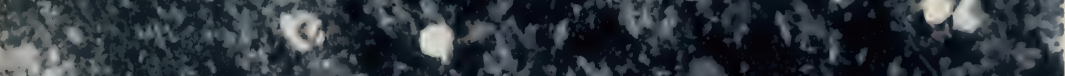

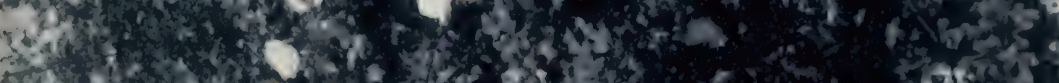

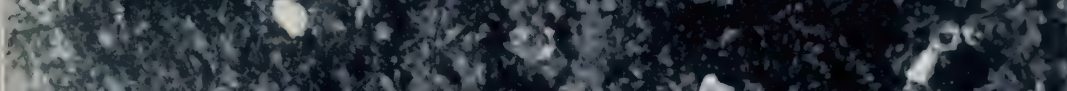

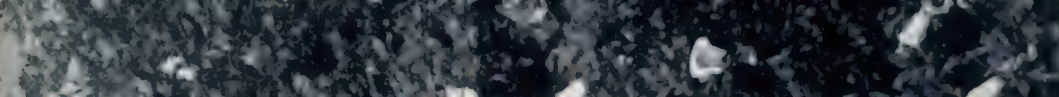
X

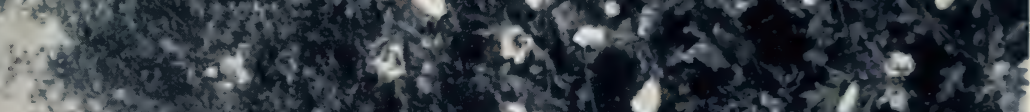

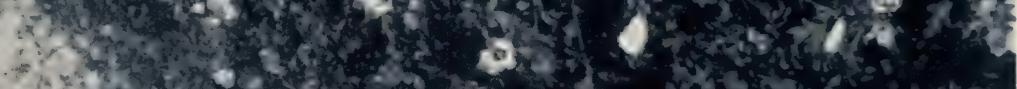

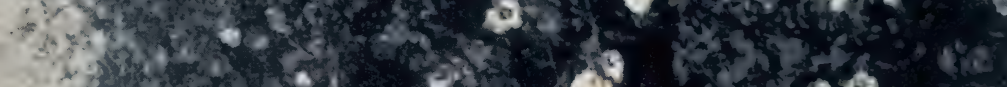

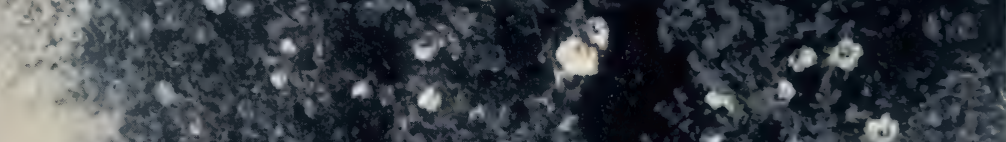

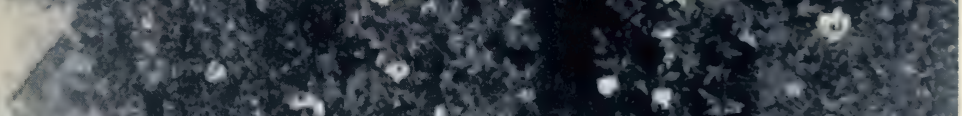

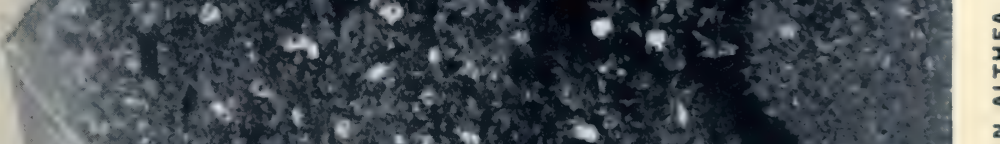

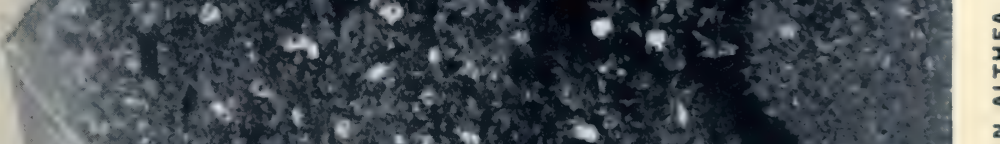

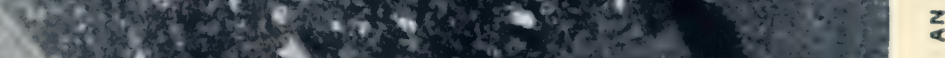



increase. Yet the land must respond - and easily by intensive farming. But first the wild lands of all the continents shall have been inclosed as farms. South America, the land-hunter's paradise, will fill up with immigrants long before the twentieth century shall have passed. But intensive farming has already begun in our America. Corn cannot be raised on Broadway, yet Broadway must have corn. Cities must be fed and the world henceforth will ever be demanding a yet more varied, abundant, and invigorating food supply. The essential measure of farm values is human necessity. Hence, in selecting the site for a farm, when the mind is made up as to what sort of farmland is desired, the would-be farmer may well pause and weigh conditions. In order to do business one must go where business is done. In order to farm successfully, profitably, satisfactorily, one must use land best adapted to the sort of farming he affects. Climate, location, associations, are the three factors which properly determine the choice of the site. Climate determines all; soil can be made; so too railroads, highways, schools, churches, post-offices, markets. Associations grow. In brief, given a favorable climate and primacy of location, all that remains to be done man can do.

All the traditions declare that health lies in farming, doubtless because no man can be a weakling and a farmer. The hayfield is supposed to restore lost health; when doctors fail, we take to a farm and carters. This tradition of identity of 
health and farming seems to be as old as the race. Yet in no vocation is invalidism a prerequisite. Farming compels good health for it puts the man to the test. No vocation demands abler or saner men. It is an illusion that farming does not require brains; that when a man has failed at everything else he may resort, successfully, to farming; that nobody can fail at that. The professional collector of statistics has neglected a field here quite untouched, as to the number of farmers who fail as farmers. Horticulture is expert-work and he who is not an expert need not hope to raise fruit,- - perfect fruit and in ample quantity. There is a difference. To raise peaches and not peachpits, merely, requires peach-thinking; not peachpit thinking. A man's mind must be attuned to the keynote of his vocation, and his vocation is to be measured as it conduces to the general welfare. Thus to a healthy mind horticulture has its pleasures; to a diseased mind, no vocation is pleasurable. We come then again to the man; his vocation depends upon his health. A sick fruit-grower means a neglected fruit-farm. The farm never misrepresents its owner. In order to have healthy farms the fruit valley must have healthy farmers. Mere residence on a fruit-farm does not generate either health or the fruit-farming sense. Fruitfarmers, like poets, are born, not made.

Yet, ignorant as we are of the laws of health, we know that earth and air are the mother of sound mind and body. The billionaire who trudges 
barefoot through the dewy grass in chase of health is more likely to find it than by going barefoot down Wall Street. The air of the fruit-farm has more ozone than the air of the office or the factory. So the conceit follows that health may be had simply by standing in the open on the farm, gazing at the scenery, and retaining your breath while you count seventeen. All this is a delicate compliment, possibly a tribute, to Nature, though rendered by a dress-suit. Were earth and air the sole elements of longevity, country people should die young as centenarians and many who knew Washington should still be among us. Indeed, some wide-eyed peasant should yet linger who could tell us whether Cæsar fell in the Capitol or at the base of Pompey's pillar, and some domestic of Elsinore could give us back-stair information whether Hamlet was really mad.

The fountain of perpetual age does not bubble up even on the best fruit-farm in the Valley, and I have seen but two and known but one centenarian there. My neighbor, at seventy-five, is renewing his youth by returning, after fifty years' absence, to the old homestead, and is converting it into a fruit-farm. Yesterday, said he to me: "If I had only known what I was to miss in life, I would never have left the Valley; there is more pleasure and satisfaction in raising fruit than in any other occupation in the world. The trouble is, we do not find it out until we are old." He had spent his life in electrical engineering in many 
lands; had amassed a fortune. He had not tried all occupations, but he was now generalizing in very bold fashion. One of the best fruit-growers in the Valley became one after having given forty years of his life to the shoe business, acquiring wealth. "I wish I had begun at the start, and not when I was old," he said. "I never suspected what I was missing of pleasure," and he was thinking, though not aloud, "of profits also."

"But the world," you reply, "is not composed wholly of successful electrical engineers and shoedealers; there are others." More money is spent to regain health than to keep it, and most men who have spent the first half of life making money, spend the second half in fighting disease and warding off death. First part, gain; second part, pain, -is the story of most men's lives. And never a Crœsus who would not exchange his last ingot of gold for a loaf of bread and a stomach to digest it. "Skin upon skin, yea, all that a man hath will he give for his life."

So again we come at last to the man, and principally to his stomach. Give me the stomach and I will not only rule the world but will live forever, -if either were worth while! Fruit-farming, like every other vocation, is a case of stomach. No business concern will employ an invalid. The basis of life is physical whether you enter the army or the orchard. Nature promptly solves the problem by applying her harsh law of survival. The world is not made of weaklings; every blade is a 
survival like the aggregate flora of the globe. There were no mules in the Garden of Eden though there are dinosaurs in the fossil beds. Æons ago these shrubs and trees and grasses of our wild did not exist, and æons hence they will be known only by the records of the rocks, - an imprint, here and there. We are all on our way to a niche in some museum. There were no Lincolns or Washingtons, no Shakespeares or Miltons, no Fultons or Edisons in the Age of Stone, nor can we foretell what shall be the type and service of man ages hence. But this we know, whether the age be Devonian or Miltonian, that the law of survival is working, and weaklings go to the wall. The world is for healthy people, though the lame, the halt, and the blind seem to possess it, and sickness the rule rather than the exception. Banish disease and death and soon we must remove to other planets for standingground. Or, would life's cycle close, and the gaps merely fill up? If the human machine wore out by age instead of breaking down by functional disturbance, decay of tissue, or accident, and men attained the normal bound of life's journey, would there be room and food for all? Having no experience in this, the world can only theorize, but if analogy can guide us, man would live his cycle, like plants and other animals: no less, no more.

The new books are always telling us that the average of life is increasing. It is the charm of doing slum-work-the "call" of the "submerged" to very worthy people - to extend life; and sta- 
tistics follow enthusiastically. The new gospel is a bath and an overcoat as against a straight dose of Calvinism, or heresy Literally it is now "wash and be clean.'

The ideal farm-house of the pioneer was a kitchen and a cellar and an outside chimney; of the farm-house of to-day, a refrigerator, a bathroom, a porch, and a vacuum cleaner. The world is obsessed by Wesley's "Cleanliness is next to godliness," and some disciples reverse the saying. Ours is the age of soap and electricity, as was Lucullus's of peacock tongues and proscriptions. The age of pork and cabbage is past; ours demands the dessert.

Yet, despite statistics, Hull House, psychology, and desserts, we have more diseases to contend against than had Naaman or Louis XIV. We must take to spraying ourselves for insects and fungi as we spray our orchards and vineyards. Congestion of people and fruit trees has invited disease. Fruit-raising is artificial, a sort of openair, hotbed work, - a case of floral over-population. The fruit-farm is a concentration of effort to trim, shape, and direct Nature to our liking. The Japanese grow trees in human shape and admire them as works of art and genius; the fruit-grower grows a cherry whose fleshy part exceeds that of a dozen cherries in the wild. All our fruits are monstrosities obtained by the exaggeration, or atrophy, of some part of the natural plant. We force the plant to run to a juicy pulp, to leaf, or 
bulb, as grape, apple, peach, potato, or currant, and thus, meddling with its balance of function, we make one part, say the pericarp, a giant, and leave other parts weaklings. The sole fate, seemingly the sole function, of weaklings is to perish untimely. So while we are raising cherries of mammoth size and exquisite color, we are killing the cherry tree. This is fruit-farming. Every cultivated plant is relatively short-lived. A fruitfarm is an assembly of plants more or less diseased because abnormal, and the burden of the fruitgrower's toil is to maintain them in a productive state. Defying Nature he yet depends on Nature. Inviting disease, he gives trees and vines medicine to cure it. He sprays leaf, stock, stem, flower, and fruit. He puts medicine into the soil as soluble plant-food. He stimulates the plant by cultivation. He invades the life of the plant and enslaves it to his own ends. Domestication is interference.

Despite this bold invasion and conquest, he maintains his plantation in sufficient health to consummate his purposes, and trees and vines, shrubs and roots bring forth some thirty, some sixty, some a hundredfold. The healthy fruitfarm is the farm which, year after year, bears its heavy harvest. This means that the fruit-grower has mastered the art of compelling Nature to produce a pericarp, a pod, a root, a leaf, a stem, to suit his ends. The plant no longer merely produces seed after its kind, but fruit after the owner's kind. The difference is the difference between the 
wild and the fruit-farm. The hand of man is on the lever. Nature serves. Yet, let him once drop the lever, cease his care, remit his domination, and orchard and vineyard again return to the wild.

Health breeds health. In maintaining the health of his vines he maintains his own. It is not a case of absorption but of use. "Use, the law of living," writes itself on men as on trees. We plow the grape row, not the porch floor. Italians are said to ripen bananas under the bedclothes; peaches and grapes are grown in the open by the touch of the hand. This is a mystery that the owner can convert soil into baskets of fruit. In digging for gold in the potato patch the farmer finds it, in every bushel of potatoes. By tying grapes in the winter the viticulturist is able to pick off a hundred dollars an acre in October. In keeping orchard and vineyard in health, he keeps himself in health. Bankers, lawyers,-I will not say doctors,-manufacturers, merchants likewise. "Keep your shop," says Poor Richard, "and your shop will keep you." Keep your health and you can keep your shop. Men who fail in business usually fail in health. Failure means disease and sickness. Men lose their grip, and then,- - "heart failure." So prosperous people are healthier than unprosperous. Like breeds like in all things, men included. Incentive is health. This gone, why breathe longer?

On the fruit-farm there is always much to do; this is a secret of health. Disease loves the easy 
chair. Leisure usually is sickness and the doctor. If he is a lover of gold he will treat leisure with respect; it is his best friend. There is leisure on the fruit-farm but not of the hopeless kind; it resembles Sunday, rather than an indefinite vocation. On Monday the weeds are still growing; indeed, they work full time, and botany fails to root them out. The fruit-grower's leisure is his opportunity to stop and think. The more the thinking, the more the fruit. Land thinks weeds and stones, unless you make it think fruit. Trees and vines think sprouts, insects, fungi, and toil for man. Once he gains the upper hand, there was never a more faithful servant than his orchards and vines,indeed, his whole farm. But once it gets the upper hand, he is amidst the wild again, - a jungle of weeds, a tangle of superfluity, a burden of mortgage and bad debts. No fruit-farmer ever catches up with lost time. Nature is punctuality. This is the greatest lesson learned on the fruit-farm. May-plowing cannot be done in July. Regularity of life is health. Nature loves rhythm and cycles, the regular swing of seed time and fruitage. Once the grower is in tune with his land and keeps on playing the tune, there is wonderful harmony in the harvest. But out of tune, he must expect barren orchards. It is not merely rising with the sun and going to bed with the Big Dipper that makes a fruit-farm; it is the work done between these interesting events that counts. Order and system are Nature's formula for health; so round 
and round and over again is the game. A scratch here and a scratch there do not raise peas or cherries. Each section of a farm at its best, the whole is a fruit-garden.

This routine is Cato's, Washington's, Webster's, everywhere the best farmer's "succession of crops." This year this section has its soil-crop of clover, next year, that section; but a third section requires special treatment: we know the needs of the ground. We have a map of the farm always in mind, and we follow the principle of the Declaration of Independence, "all sections are equal." Regularity and routine are the conditions of fruit-farming, but the farmer must mix them with brains. Land has its peculiarities like folks and must be humored. A ton of ashes on this piece; a ton of phosphate on that: stable manure on this; Alsach clover on the other. There is no hard and fast rule; one must know his land. Here is occupation for leisure hours.

We go much by colors in fruit-farming: a scanty growth of foliage, a light shade of green, a premature brown,-we recognize the signs; the soil is hungry for nitrogen. Small, scanty, dropping fruit means tree-hunger for potash. But abundant foliage year after year and no fruit means practically the wrong sort of tree. Why cumbereth it the ground? We cut it down, grub out the root, and cast both into the brush-pile, strike a match and scatter the ashes around the tree that has both leaf and fruit. To trees as to persons that have 
much, much shall be given, and from them much is expected. The fruit-farm must not be suffered to run to shade trees. All this means thought and activity in the owner,-and activity and thought are health.

But there are other friends on the fruit-farm, foremost among them "Nature dressed in living green." Our very interference with Nature intensifies as well as creates our interest in her. She is the undiscovered country, the unexplored mystery, the untried experiment. Our ignorance is her opportunity. Not that with knowledge come all our woes, but that the invasion of Ignorance and conquest over him is the god-like deed of man. In dressing land we clothe our own souls. It was the earth, the land, not Adam that was cursed, and to him dominion was given. The ancient story conceals life. Idleness is death. In subduing the wild, man becomes immortal. Fruitgrowing is a long process of land-conquest, as yet hardly begun. The Hanging Gardens of Babylon were made famous by the arches which supported them, not by the fruits and flowers they bore. It was the engineering not the apple that made them one of the Seven Wonders. On the fruitfarm it is still the engineering that works the wonder. It is the selection of the land, the making of the soil, the kind of tree and its planting, the cultivation of the ground which produce the wonder. This done, apples, peaches, grapes, cherries, berries follow as night the day; as echo, the voice. 
What have we in this bunch of red cherries and of purple grapes? Engineering. The man thought and did, and 1o, this fruit! No thinking, no peaches. "Yes," you interrupt, "but what of frost, wind, hail, blight, and borer?" I reply: There is no peach but thinking makes it so, and the more you ponder this, the better judge of peaches you will become. Climate makes the peach possible, if only some one thinks peaches. For the peach is as much man-made as a piano. There are no Steinways at the North Pole; the climate is unfavorable; nor peaches, nor people, for that matter. The law of peaches is climate and man. He thinks out the peach, the cherry, the grape, the apple; no thinking, no fruit; only the seeds of the wild, which are not our fruit.

Thus in fruit-farming man is a creator, and creation, procreation, is health. Iron and steel and stones cannot think; "as dumb as a rock" has much significance. Stones neither grow old nor sicken; they exist. But man must do more than exist,- he must think and act; and because the fruit-farm offers him opportunity, it makes for health. Every profession exalts itself; and every fruit-farm is the best farm, so says its owner. His ideals may be ahead of his deeds.

A man is a creature of parts, wonderfully made and assembled, and wherever these parts function best there he should live,-if health is his purpose. Theoretically health is every man's objective; practically, it is only a possible objective for many. 
Most men sell their lives at so much a day, from two coppers in China to thousands of dollars in Europe and America. The love of money-whatever that signifies - makes the bargain. It is idle to expostulate. The habit is fixed with the race. The greater the risk, sometimes the lower the pay. Only a few people think they can afford to be healthy, just as few can afford to live economically. To these few a word is sufficient, for none are so deaf as those who will not hear; none so pitiable as those who hear and are prisoners of their deafness.

What is the objective? Health? Wealth? Pleasure? Knowledge? Length of years? Fame? Leisure? Service? Drifting? The Unknown? Really this is the question, come to it as we may, whether by way of the factory or the fruit-farm. I suspect that the question has long been answered: "Length of years, riches, honor." Now riches and honor are relative, but length of years is absolute. There is a cycle of life for every plant and animal, according to its kind. Robins live say fifteen years; turtles five hundred. It is the way of turtles and robins. And how long shall a man live? "A day, and yet forever," answers one; "fourscore and no more," replies another. Schools of thinking differ here also. But we are speaking of this earth, not of some other universe. "Oh!" replies the young doctor; "in that case, barring accident, as long as his arteries keep elastic." There you are. "Know thy arteries," Socrates should have said. 
"I am looking for a climate," is the invalid traveler's constant plaint; he means, of course, that he is looking for elastic arteries. They are health. Being now definite, we can test our habitat, our fruit valley - wherever it lies - for arteries, just as physicians take the pressure of the blood. For blood-pressure is symptomatic. So too are vocations, as any one may know by perusing the reports of life-insurance companies. "Occupation, fruit-growing"; "cashier in a bank"; the company figures nicely on the risk and takes the man who is likely to pay premiums the longer time-judging by his arteries. Life insurance is common among bank clerks; uncommon among fruit-growers, for they prefer, like some steamship companies, to carry their own risks. He has the farm as insurance; the clerk has his month's salary. The fruit-grower has earth and the open; the clerk has the park and the street, the office, bank holidays, and two weeks in August for Atlantic City, or the Canadian woods. The fruit-grower has the security of his land; the clerk, the secret of his earning power-which is his health-and this he is insuring. The fruit-grower falls back upon his fruit-farm; the clerk upon his insurance policy. But the insurance policy means annual premiums to the company; the fruit-farm, annual fruit to the farmer. A few years after I began fruit-farming, I took out an endowment policy in a great mutual company. I was examined duly by the company's physician and pronounced a good risk. 
For twenty years I punctually paid the premiums. The day of maturity came, and, after pondering over the "choices" for settlement, I made mine, by the terms of the policy and the written agreement of the company, signed by its agent. When the day of settlement came, the company repudiated the act of its agent, made out its own figures, stated briefly that so it would settle, and "begged to hear from me." My vision of twenty years faded. Three thousand dollars went with that dream. I expostulated. The company explained that rates of interest had fallen in twenty years and earnings had not been so large as were expected. But now it was issuing a new, a different kind of a policy to the old line endowment. Would I not be examined by the company's physician and take out another policy? I could make a better investment under the new plan. My curiosity was aroused. I took the examination and was congratulated on my arterial pressure which (the company's physician said) indicated a man twenty years younger. I settled with the company and thought pleasantly on my arteries. Meanwhile my fruit-farm had been in the making; this explained the arterial pressure. Instead of taking out another policy-on the new and improved model-I bought more fruit-farm, not wholly unmindful of arteries. But I will be just. I do not overrate the fruitfarm nor underrate the insurance company; I think on my arteries. It was the fruit-farm 
which kept the arteries elastic, not the insurance company.

One of the annual premiums of the fruit-farm is health; usually, with insurance companies one must die to win, and lose in order to collect. Meanwhile life has its pleasures in the fruit valley.

It would be unfair to any fruit valley to represent it as free from sickness and disease; it too has doctors, and patients by the thousand. Indeed, in the fruit valley, sooner or later everybody sends for the doctor. Yet I have never heard that sickness there is due to fruit-farming. Health is the rule. But this, you say, is generally true in America. There are vocational diseases which must be reckoned with, like phosphoric poisoning in the making of parlor matches (of a certain kind); lead-fumes in the manufacture of paint; gout among heavy capitalists, and lung troubles among mill hands. When appendicitis was discovered by the public, some twenty-five years since, it was promptly attributed to grape seeds, yet though the Valley is a vast vineyard, appendicitis is not epidemic in "grape time." And it may be asserted confidently, that no case of appendicitis can be attributed to the seed of any fruit. Cherries and milk are fatal, yet though the Valley raises thousands of bushels of cherries and milkmen abound, no cases are reported. Some say that the milk is too well watered to be fertile of cherry indigestion, and, moreover, that cherries sell so well in New 


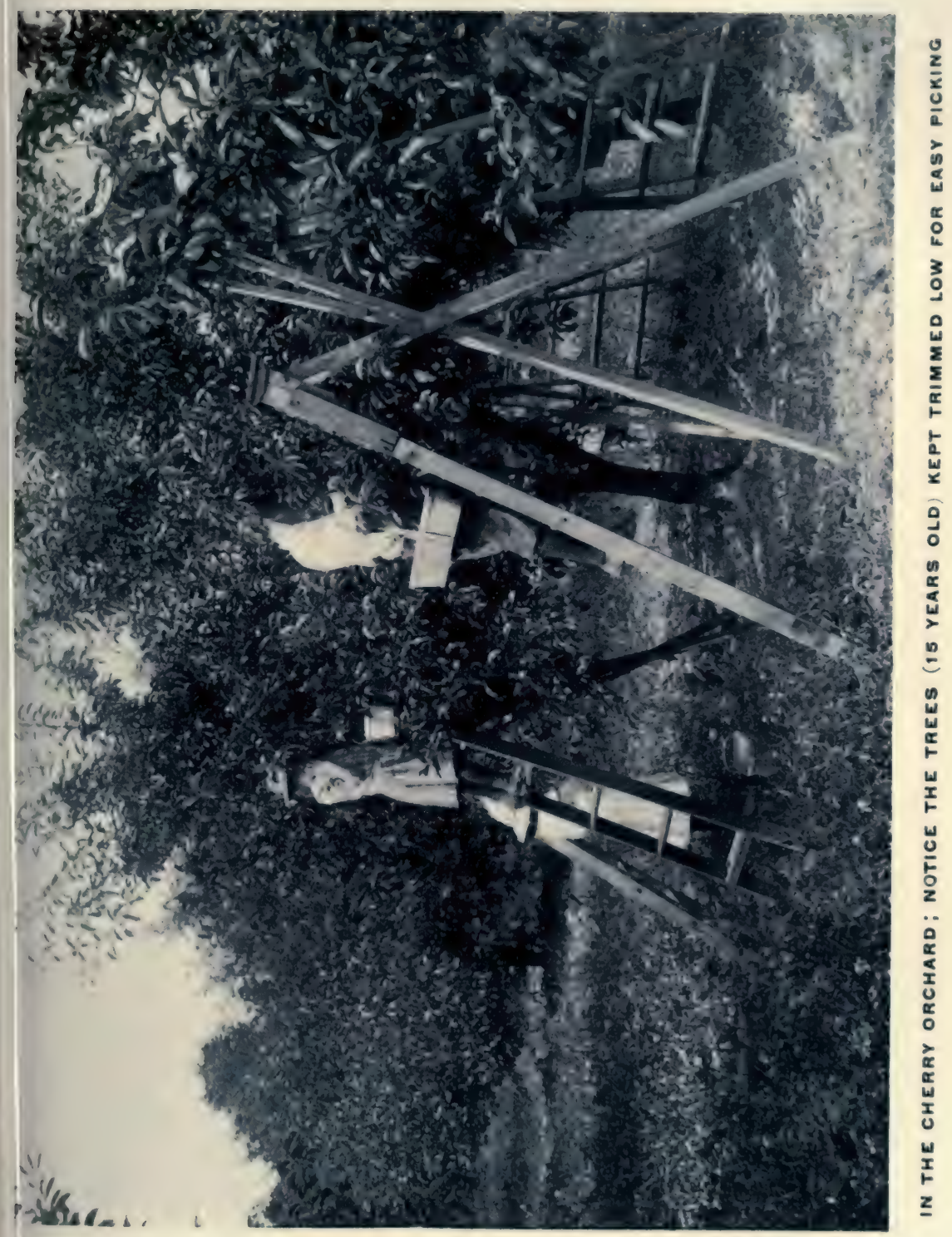



York and Pittsburgh and Chicago that the pickers cannot afford to eat them. The elevation above the sea-five hundred and seventy-three feet at the lake and thirteen hundred and more feet along the crest of the Valley - is too high and the winds too dry for lung troubles. But the water from the limestone in the Devonian Hills at the south is so hard on the human frame that when pickers tumble, without notice, from cherry trees, they may crack their bones; although some pickers use water only as a wash. Because of this, their aversion, other liquids are consumed, as in other valleys in America. This is one of the perils of fruit-farming. Despite these drawbacks, the health of the inhabitants is reflected by thousands of acres of fruitful orchard and vineyard. These are the fruit-growers root and branch. Not every fruit-farm betokens a healthy master. Farms get down at the heels and lose hope, and so merely hold the world together. The healthy fruit-plantation means a healthy owner. Valleys and plains the world over illustrate this truth.

But here, in the beautiful Valley, men are thinking and doing, and so are healthy. Some might think harder and do more; some year after year think and do less. So there are stationary fruitfarms, like bowlders, left by the retreating ice of the Glacial Period, ages ago,--mere monuments of former progress. It is no art to find the complexion of the owner's mind in the appearance of his vineyard. The Valley is a good place in which to study 
what may be called vegetable psychology-not merely to tell how long it takes a man of 32 years, 5 months, 7 days, 2 hours, 13 minutes, and $3 \frac{2}{3}$ seconds, at high noon, to think, but also how long he has been thinking and when he ceased to think. For as a man thinks so is he and his fruit-farm. Years ago, in the days of pioneering it was oats and barley, buckwheat and potatoes, rye and wheat, corn cattle, sheep and horses; but the thinking of the Valley no longer takes these antiquated forms; it is peaches, cherries, grapes, prunes, strawberries, raspberries, currants, plums, gooseberries, apples, melons, some corn, a little wheat, less oats, a few potatoes, and a somewhat neglected vegetable garden. Fashions change in thinking and so in farming. Our grandfathers thought in terms of ox-teams; we, of automobiles. We are warned not to put our trust in the legs of a horse and we are rapidly learning not to put it in the brake of an automobile. Sufficient unto the day is the evil thereof. As many fruit-growers now have autos, some new perils are added to the ancient list. It may be possible to run a machine and keep in good health, but not all autoists have as yet learned the secret. Some manage to keep in fair health without machines. Whence the conclusion that autos are not necessary to health, or even to fruit-farming. Yet, as an automobile gives its owner much to think about, and, as it ages, keeps him increasingly busy, and as thinking and doing are conducive to health, owners and users of 
machines should be by right husky men, well conditioned for length of years.

The coming of the machine has made the entire Valley-like other valleys - an accessible neighborhood and has shortened its length from fifty miles to sixty minutes. And if the owner turns turtle, he may report by telephone at the first farmhouse. So a stroke of invention has made neighbors of us all. This too makes for health. No longer the sickness that comes from isolation; no more the bad fruit-farming that comes from not knowing what your thoughtful neighbor is doing. So the Valley is improving, if by no more than by active imitation. The tradition that farming is health is thus borne out. The weaklings sell out and emigrate, and the fittest survive. For more than half a century now the process of natural selection has been active in the Valley, and to-day the survivors themselves are passing through the winnowing process. Clearly the Valley illustrates the effect of domestication on man. Possibly the process has been hurried a little with land at from four hundred dollars to one thousand dollars an acre; but at a thousand an acre some land in the Valley is cheap; and at one dollar an acre other land within it is expensive. It depends upon climate and the man, rather than upon the land. The man depends upon his health. Thus again we come to the man, and this means, when reduced to lowest terms, to the state of his health. Invalidism may possibly be an avocation but never 
a vocation. A fruit-farm is not a sanitarium, though sometimes put to such a use.

Back to the earth and the open, actively induced by interest in the vocation of fruit-raising, a man, not too old to get well, may regain health. But to use a farm as a medicine, "one drop in a pail of water," is merely a change of doctors. Even the rival schools of medicine do not pretend to change the pharmacopœia. Cherry trees sometimes grow elastic arteries; so too, ranching, or hoeing corn or taking the grand tour by Karnak, Egypt, and the Holy Land; for only healthy people survive Jerusalem. No one comes to the fruit-farm too young, but it is easy to come too old. Happy the man who inherits not merely acres but the love of cultivating them.

The true fruit-man would rather raise fruit than eat it, which is not an instance either of commercialism or surfeit,- - only of a pleasant partnership with Nature. Every sane man yearns to be a creator. Man is the maker as he is the thinker, and his cherries are never finer than his thoughts. He who has not experienced the joys of growing things knows no more than the pleasure of seeing fruit for sale in the market. First the leaf, then the bud, then the fruit,-but always the man. The sacred books record that the Creator was pleased with His handiwork, and in this men resemble their Creator. The poet is poet because he is a maker, and we call him of low degree still a versifier, or maker of verse. It is then a divine 
touch that makes kinsmen of us all-the love of creating, be it a railroad, a watch, or a fruit-farm. Here is the secret of health,- - to create, to enjoy the creation. The personal equation must be figured out by every man. Some men, at ninety, can run a railroad, but the usual age for retiring is not far from sixty. "The machine," after that, as Hamlet would say, "is no longer to him." The wheels creak and the grist runs low. The railroad president finds pleasure in the system he has built up; the fruit-grower, in the plantation he has made. And many fruit-farmers are worn out at sixty and fail to reach ninety. It is the man, not the railroad or the farm.

Innumerable are the books which tell us how to be strong and stay so; how to be well and happy. In a drug store, as one glances about and reads the labels on the bottles and the signed testimonials, he may well wonder not why any should die, but why any take the trouble to be sick. Or he may have a more painful thought: how take all these potions and live. Yet we live and we die despite the apothecary, despite the fruit-farms. Doctors, in their puzzled moments, are likely to send the patient off on his travels. It is an open secret that the good doctor's purpose is to get the patient thinking about something else than himself. Fruit-farming is this resource; the farmer always has something to think about and to think hard. His thousands of vines and hundreds of trees keep him busy. Wind and storm, frost, 
snow, hail, sleet, lightning, insects, fungi, changing fashions for fruits, prices, the market, and all the certain uncertainties of the entire fruit vocation furnish a complete encyclopædia of diverse provocation of much thinking. The fruit-grower has plenty to do, plenty to eat, and plenty to think about, - which is the very tripod of health and sane living. He therefore should be a healthy man, having all these things and living on the earth and in the open. 


\section{III}

THE PLANTING OF THE FRUIT-FARM

WHETHER in the wild or under cultivation, climate determines the survival, and therefore the selection, of varieties. Soil merely holds what climate permits to grow. Exposure, slope, wind-ways, moisture, are details of climate. A multitude of varieties means the multiplication of weak stock; survivals are known as standard varieties, vigorous, and, with ordinary care, producing fruit. A variety, unadapted to a locality, struggles for existence and becomes a mere shade-tree. Cato, in one of his "Fragments," says: "Trees that bear fruit are happy; those which do not bear, unhappy." Perhaps this means varieties adapted to location. Planted in deep, rich soil, the standard variety fruits productively, or, as the old Roman would say, "happily." A hillside may be, and usually is, wet and springy; even a slope may lack under-drainage. In setting the fruit-plantation, one must consider drainage, exposure, direction of prevailing winds, nearness of woods and forest as windbreaks, open spaces of lake, river, or valley, and the habit of the plant, be it tree, shrub, bush, or vine. 
Most men are in a hurry to get the fruit-farm into profitable bearing, and are tempted to select for planting stock that is too old. Small young stock is best: grape roots one year from the cutting; trees one year, in some varieties two years, from the bud. The shock of replanting is always great, - much greater than we realize; therefore plant young, vigorous roots. Vitality is the main thing. Bruised roots and rootlets are gateways to disease; therefore make a clean cut with a sharp knife, leaving the end of the root, or the end of the branch or twig smooth. It rapidly heals over, in health, unless the wound be a laceration, big and rough. Many trim the top but ignore the bruised and broken roots. In handling stock from the nursery, keep it covered, especially the roots, from sun and wind. Either will dry out and kill the rootlets, and these are the mouths and stomachs of the tree below ground,- the counterparts of leaf and twig in air. Trim after the tree or vine is set, when you can see it from all sides; otherwise you may have cut off the wrong branches. The tree is to be kept ever in balance and its poise cannot be known till it is properly set.

As you would first work your corn-field before planting corn, so will you first work and lay out your land for orchard or vineyard. The careful man, in laying out a large tract for orchard or vineyard, may employ a surveyor, for tree rows and grape rows; the orchard and vineyard sections 
will stand for generations and cannot be changed. Straight rows look best and economize labor. Trees must be in line in whatever direction the eye follows them, and an orchard must be cultivated, at times diagonally as well as at right angles. The tree must be set with respect to its habit. This slender stem you plant will become a canopy of foliage and fruit, upraised on a stately trunk. You must see the full-grown orchard in its infancy. So the orchardist must grant ample space of earth and air, for roots below and foliage above are counterparts, - the two halves of the living thing you plant. In fruit-raising, we cut back the top and encourage spread of root in order to secure concentration of vigor in fruit and foliage. We must know that a rich soil means a rapidly growing, large, healthy tree; a thin, poor soil means a weakling. Therefore in planting an orchard we must consider the soil. I give two distances,- the greater for the richer soil:

Apples

Pears (standard)

25 to 40 feet each way

Pears (dwarf)

Quinces

Peaches

Plums

Cherries

Blackberries

\begin{tabular}{|c|c|c|c|c|}
\hline & $\phi^{\prime}$ & & & \\
\hline $20^{\prime \prime}$ & 25 & “" & " & " \\
\hline $12 "$ & I 8 & $\because$ & $"$ & " \\
\hline I6 & & " & “ & "، \\
\hline I6" & 24 & “ & " & " \\
\hline I8“ & 24 & “ & “ & " \\
\hline I8“ & 20 & $"$ & " & “ \\
\hline 6 by & $4 \mathrm{f}$ & eet & & \\
\hline 6 “ & 3 & “" & & \\
\hline 6 “" & 4 & " & & \\
\hline $6 "$ & 4 & “ & & \\
\hline
\end{tabular}

Raspberries

Currants

Gooseberries 
Strawberries

Grapes
I foot apart in the row; the rows apart for cultivation with a horse,say 3 feet at least.

8 feet apart in the row; the rows 9 feet apart, so as to admit modern, two-horse tools, sprayer, grape wagon, etc.

The essential problem in planting is twofold: to secure feeding and breathing space for the tree and ample room for cultivation with horses and modern tools. An apple tree will grow fifty feet high, but fruit at that height is out of reach. So too a cherry tree, a plum or prune or peach, will grow too high for practical use. Any tree which must be picked with use of a painter's ladder instead of an ordinary, commercial, picking ladder, costs more than it is worth. A fruit-tree must be kept low, and therefore out-spreading. This means ample space and wide planting. No man ever regrets giving his trees sufficient space in which to fruit low. Ground fruit, such as berries and all vegetables, must be planted according to the care they are to receive. In Germany, and in Europe generally, all labor in the field is by hand, and therefore the space between rows is narrow,usually little more than the width of the hoe for vegetables. In America hand labor is unusual,is too costly. All work is done with a horse, or, on most farms, with a team. Twenty years ago tools, such as cultivators, drags, plows, and spraying-machines (if any), were small, light, and narrow, 
rarely having a spread of over six feet. To-day the spread is nine feet and two horses must be used. A fruit-farm, in order to be both scientific and practical, must nowadays be run on a generous scale. The fruit-garden may be run by hand; the fruit-farm must be run by horse power. Yet if the ground fruits-berries, tubers, and the likebe planted closely and in narrow rows, and the ground be kept rich and thoroughly worked,intensive cultivation,- the grower will get far more from his land than does the fruit-farmer who runs his farm by horse power, acre for acre. One need but compare production in Germany with that in America, on equal areas, to discover this. But in America we have not cheap farm labor. We are compelled to rely on teams and tools and a few hands to run them.

In planting, keep the roots from bruising; cut injured parts clean away to escape root and branch diseases. Avoid bruising the bark, the limbs, the twigs. Cover bruised parts with a coating of pitch, paint, or formaldehyde to keep out air and water and germs, and the numberless spores of fungi floating in the air and quick to take lodging in the wounded plant. Even a coat of painter's oil is a protection. In time the tree will heal the wound, if possible. For a few years a young tree or vine will flourish, then suddenly show signs of disease and die before your eyes. The spores of fungi got in their deadly work where you left a wound of bruised bark or mangled root. Your 
years of labor and waiting are wasted. Treeplanting is largely a problem of securing breathing space in earth and air. Most growers sooner or later regret that they had not planted farther apart, giving ampler space for growth. The condition of the plant, at any time in its later history, will be determined by space as well as by cultivation. It is yours to trim, to fertilize, to cultivate; the tree has only to grow. Thus soil fertility and control of the plant are your problem. Your supreme purpose is to concentrate the strength of the soil upon the plant. The whole life of the plant must be active in production of fruit: this is the supreme function of tree, vine, bush, or shrub.

It is an easy labor to set out trees and seemingly to plant an orchard. Land may be plowed, harrowed, marked, and so, on the surface, be made ready for the young trees. But trees root deep,indeed, produce as much area of feeding surface in roots as of feeding surface in branch, twig, and leaf. No fruit-tree grown in North America will flourish in water or in dry earth; nor will it flourish in soil which passes from water-soaked to ashendry condition. Extremes kill the tree. In planting an orchard, the most important question is of drainage. Happily, most cultivable land so slopes as to be, as it is said, self-draining; which means that the subsoil, even the surface, is neither water-clogged, nor as dry as parchment. Water, in form of moisture, is ever circulating through a well-drained soil. The earth acts much like a 
lamp wick, and ever exhibits the process of capillary action. This action prevented, the soil becomes fatal to the root of vine or tree; the soil becomes water-soaked, or parched.

But many a field otherwise adapted to orchard culture is not adequately drained. Its geological structure may prevent such effective drainage as is desired; the layers of the soil; the strata of the rocks, or even the slight undulation of the surface may have the effect of a series of dams, holding back the water, and so soaking and clogging the soil. The only remedy is drainage, which is of two kinds, - by a ditch, whether open or covered, leading to stream or lake, or by drainage wells, fed by such a ditch. The simple problem is to prevent standing water. If the land is saucer-shaped, as to surface, and bottomed by hardpan, water will stand within the hollow as in a metal basin. Either cut a ditch across the edge of the basin, letting the water escape into stream or lake; or sink a drainage well, piercing the hardpan, thus letting the water sink through a porous bottom and thus vanish. But dig the drainage well, not in the middle of the low spot, lest it fill and remain full; for the sediment will tend to choke the gravel bottom to which the well was dug. Sink the well in gravel soil at the edge of the low spot, even many rods from its center, and having by accurate leveling ascertained the necessary drop to carry off the water, dig the ditch from the center of the low spot to the well, through gravel, if possible, for the water, 
passing through the tile at bottom of the ditch, will sink into the gravel all along the length of the ditch, and ordinarily fail to reach the well. Cover the ditch with care, and care consists, in laying the tile, say four- or six-inch as may be needed according to the amount of water to be carried away; the tile lying end to end, in foot lengths, the joints open, and protected by small flat stones, set like the peak of a roof, over the joint. Fill the ditch, covering the tile, to a depth of a foot or more with loose stone,- - small round-heads picked up from the farm. This stone covering acts as a drain and filter. If the soil through which the ditch is dug is hard clay, or close loam, it is well to cover the loose stone with strips of burlap,-old phosphate bags, which will keep the superincumbent earth back from washing into the spaces between the stones, till the earth has hardened, or "settled." This simple protection secures a practically open run-way for the water at bottom of the ditch, to a height, say of the imposed stones. At the entrance to the ditch, near the center of the low spot, cover the stone-laid atop the tile-with coarse gravel, say for a rod. This makes sure the easy entrance of the surface water as it accumulates after a heavy downpour. The drainage well itself is dug to a depth which gives coarse gravel as a bottom, to an indefinite depth. The well, walled up with loose stone, like an ordinary water-well, should be four or five feet in the clear, and may be arched over at the top; or covered with large flat stones, or with 
a cover made of cement and cast in a wooden frame. The well may be covered so that the plow cannot strike this arch or cement. Of course the careful fruit-grower keeps a plot of his land and locates on it all ditches and drains.

Better than the ditch and the drainage well is it to spend a few days, before setting out the orchard, with team, plow, and shovel, and a crew of men in leveling the proposed orchard field. Fill up the hollows; cut down the hillocks; you will save greater cost in drainage wells and ditches and dead trees. It takes a dozen years to produce a tree in full bearing, and well-drained land need know slight if any loss of trees because of either watersoaked or parched land.

Once the subsoil is drained, the tree knows no serious hindrance to rooting. Extremes of flood and drouth are prevented. And if the tree thenceforth is adequately cared for,- - by trimming, spraying, cultivating, soil-fertility, and wind and weather, the fruit-grower may reasonably expect his reward. Drainage at bottom and cultivating at surface are only parts of the care of an orchard. The simple but inexorable rule, not to set a tree after it starts to grow, - in the spring, or before it ceases to grow, in the fall,- and a second and like rule, never to plant an orchard on undrained land, may be accepted as the orchardist's chief guide. Therefore it is well, if trees are to be set in the spring, to get the land ready the fall before; or, if to be set in the fall - an admirable time for most trees, - to 
get the land ready during the summer, say in August, when the water is low, and ditches and wells may be dug most cheaply and effectively.

Subsoiling is a process of draining: the subsoil plow following in the furrow of the ordinary plow, breaking through the hard earth to a depth of several inches, making it porous, ventilating it, and enabling plant roots easily to find their way through it. Land which is thus locked at bottom and impervious may well be thus plowed deep before trees are set out, but subsoiling is useless as an attempted corrective of hardpan. Or if the land is a thin, shallow soil resting on strata of rock, subsoiling is equally impossible and valueless. The best land for fruit is land naturally well drained: land overlying a rocky or hardpan bottom at a depth of from eight to twenty feet. The impervious bottom aids in retaining plant-food in the soil. Soil which is sandy or gravelly to a great depth is expensive to keep fertile,- the foodsupply ever dissipating; or land which overlies hardpan or stratified rock, a few feet below, and sloping sharply, is drained too rapidly,-being, in fact, a mere cover for a perpetual underground stream which carries away fertilizer. It is folly to set out an orchard in shallow soil, say of two feet depth, or less, for, later in the life of the orchard, heavy winds are likely to uproot the trees. The roots, in such land, strike downwards till they reach the rock or hardpan, then spread laterally but have not sufficient overweight 


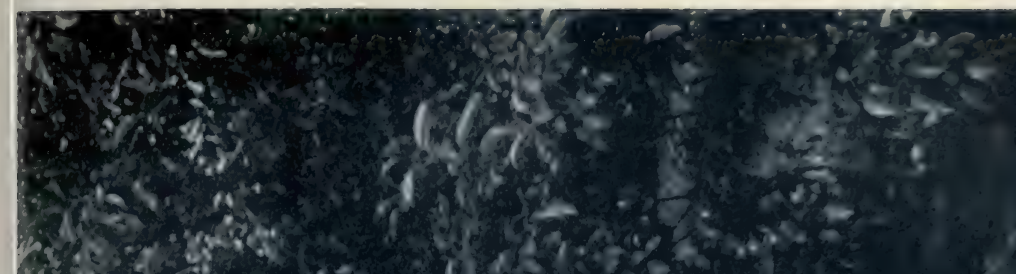

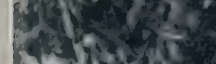

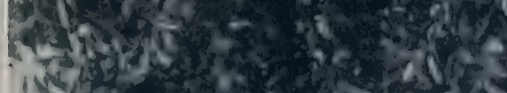

\section{8,40}

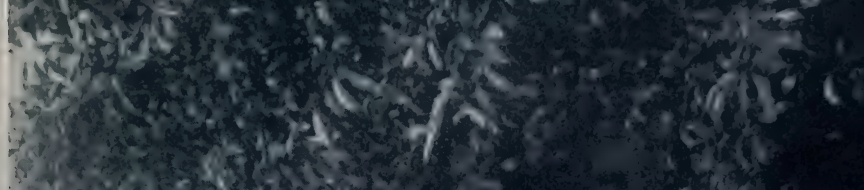

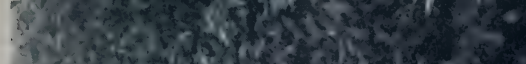

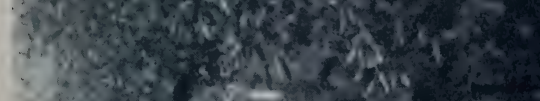

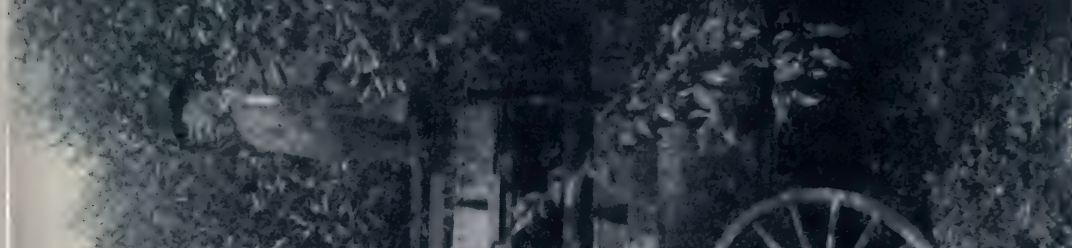

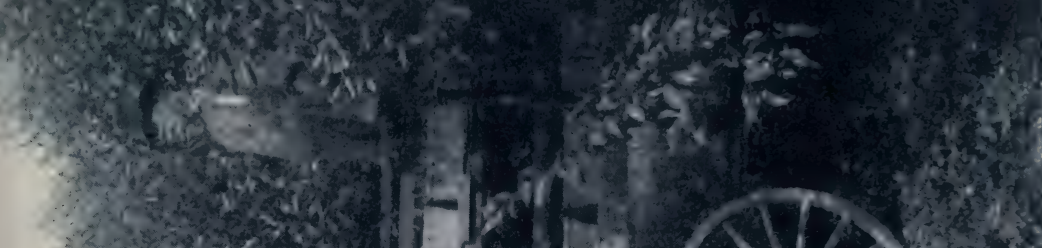

(x)

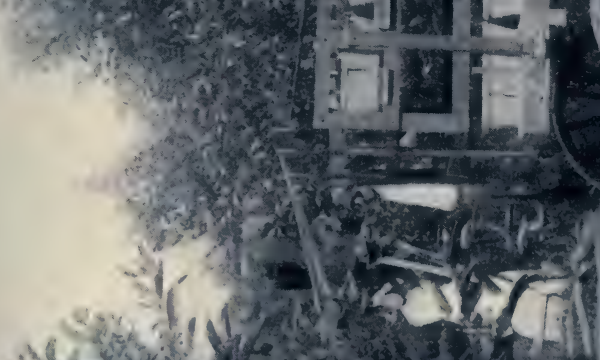

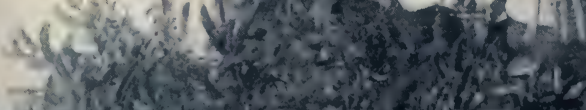

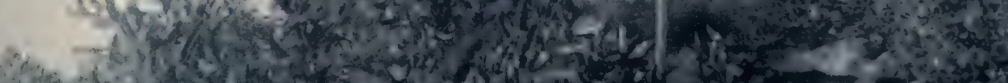

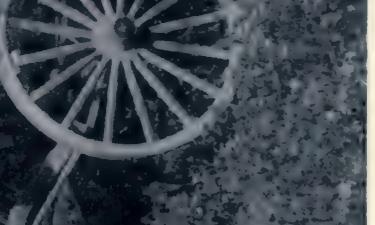

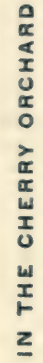



of earth to counterbalance the violence of the wind.

Subsoiling does not always correct the evil of an impervious stratum, for the earth soon settles back to its primitive condition. After the orchard is once planted, subsoiling cannot be done, unless possibly in the case of dwarf pears, whose roots tend to cluster rather than to spread laterally. But to subsoil a grown orchard of apple, cherry, peach, or prune would be fatal to thousands of roots and doubtless kill the trees. For surface crops, as strawberries, grain, truck, and even raspberries, subsoiling is often a help. Far better is it to drain the land by tiling, as explained above. The supreme purpose of subsoiling and tiling is to give a permanent outlet for superfluous water. The subsoil is commonly said to contain ingredients poisonous to plant-roots, which means that stagnant water kills the kind of vegetation attempted by the fruit-grower. It cannot be too well understood that fruit-stock will not grow in standing water, hence the necessity of drainage. The tiledrain is worth more than the subsoil plow; both may be necessary in preparing the land for the new orchard.

Having marked out the land for orchard or vineyard, you dig the holes. Some advocate digging with a stick of dynamite, but the thoughtful man knows that if land is so hard and rocky that a hole in the ground can be made only with dynamite, the roots of the tree will be limited by 
the loosened earth; they soon strike as it were a metal casing and growth ceases. It is precisely like attempting to raise trees at Atlantic City. There the hole is dug in the salty sand and is filled with soil imported from the mainland. The tree lives till it has exhausted the imported soil; if longer, new soil must be supplied. A like condition prevails near Chicago. Spread the roots carefully with the fingers in the loose earth, at bottom of the hole. Let no fertilizer of any kind come in contact with the roots. Cover these with earth only, and on top of this layer of soil scatter the fertilizer, sparingly. I have had best success when the hole is filled to within six or eight inches of the top with soil, then fill in with well-rotted barnyard manure and cover as a mulch. This keeps the whole root-mass moist. Do not water the tree, and never pour water about the tree without afterwards throwing fresh earth on, to prevent baking of the soil and closing up its pores. This means that plants should not be set when the ground at the bottom of the hole is dry as powder. There are times amidst an unusually dry season, in spring or fall, when plants must be set, or planting go over another year. Then water may be poured into the hole before the plant is set. The soil filled in will act as a mulch. But such planting is inadvisable. Again, after plants are set, growth may set in. If irrigation is necessary, wet the ground thoroughly. Moisture for roots comes chiefly and naturally from below, not 
from above. The best irrigation is to keep the ground, the surface, constantly stirred. This is equivalent to a rainfall and is more beneficial than irrigation. If you keep the cultivator running through your plantation, you will not need irrigation.

All plant-food is soluble, therefore it should reach the plant as moisture. In the laboratory of the soil the change is from solid to liquid. The thin walls of the root-cells absorb moisture, feeding on the soluble food as it passes through the cell walls. Therefore all fertilizers must dissolve or decay, must break down into liquid or gas in order to become available plant-food. This law must be recognized when trees and vines are planted. Raw fertilizer touching the roots poisons them; but a neighboring supply of food for the speedy use of the young plant helps it tide over the shock of transplantation. I have found it desirable to set the young tree deeper than it stood in the nursery. As a rule, deep setting means a greater supply of food to the root. Grafted trees-pears, cherries, prunes, plums, peaches, indeed all trees which are grafted or budded at the root (of course, apple, or other varieties grafted in the stock, excepted)-should be set so that the bud-stock will be covered, otherwise the latent buds in the wild stock may burst forth into perennial suckers of endless annoyance. A grapevine, being a cutting, not a graft, gives no like trouble, but should be set so that the top bud is quite even with the ground. 
There is a notable difference in budded fruit-trees. Some are so budded that the growth at the point of budding becomes much greater in diameter than that below the bud. This means that the budded stock grows faster than the original stock on which it is budded. The result oftentimes is the bursting of the bark above the point of budding, thus letting in fungi and insects and disease. The remedy is to buy stock of even growth with the original root stock, and also to set the tree well below the line of budding so that the sun may not scald the bark. The best preventive is not to buy stock so budded, for after the orchard has stood, say a dozen years, the trees,- - notably sour cherry trees, will suddenly die without notice.

All plants when set-trees, shrubs, vinesshould be thoroughly tamped-i.e., the earth should be fully and firmly pressed down, as it is put over the roots, imbedding the rootlets and preventing their drying out. The common method of setting strawberry plants is an illustration. Usually the farmer chooses a cloudy or even a rainy day for setting them. He uses a piece of wood, a sort of conical trowel with which he first presses out the hole, then, shaking out the roots, he holds the plant amidst the hole and with the tool presses the soft earth firmly about the roots. Many a tree perishes because the planter neglected to press the soil firmly about the rootlets.

All fruit-trees and nut-bearing shrubs, except 
apricots, are best planted in the fall. The season is convenient for the work and the tree is in order for starting growth in the spring. Many orchardists insist, however, that peaches should be set in the spring. It is possibly well enough to plant in the spring if you can get your nursery stock early enough without risk of being frosted during transportation. Grapevines, berries, currants, should be set in the spring. Climate and location must be duly considered. It is presupposed that the ground is in order,- - a preparation easiest made in the fall, or late summer for fall planting. This preparation implies the adaptability of the section to the immediate purpose. Wet, undrained land is not adapted to fruit of any kind. Cherries and peaches do best on dry, well drained soil. A stony soil is no detriment to the tree but is expensive to cultivate. Plums, prunes, and apples will prosper in moister land than one may wisely select for peaches or cherries. In planting orchard or vineyard, care should be taken to have the sections accessible by alley or road, and so to set the rows that there shall be little or no waste of time and labor in cultivation. Short rows and frequent turns are hard on men, team, and tools and run up the labor bills. Have the turn at the end of the row come in alley or road, and waste no land. The farm that abuts on the highway has the advantage of economy in use of land and in turning the team. Plant land to the limit of the line if possible and make the turn in the 
roadside. As in Germany, plant fruit-trees along the roadside and so get use of the land. In a fruit country there is the least disturbance of fruit by thieves, for everybody is a watchman. Care should be taken to lay out alleys and roadways economically, for they cost the use of the land, the land itself, and the upkeep of the road.

All berry crops are short-lived: strawberries two years; raspberries not more than ten; currants and gooseberries somewhat longer. An orchard or a vineyard is planted for an indefinite period. Apple trees are long-lived and usually bear profitably when fifteen years old. Individual trees and some varieties begin to bear at seven years from planting. Apples on young trees are like a child's earnings, small and infrequent, and rather hard on the child. The tree thrives best on well-drained, strong land. Our memories are of the old orchard, a cool, cavernous, fruitful retreat, the home of birds and bees, or waving grasses and fruit-laden boughs, of tall ladders too, and the shaking of top branches, the rattling of apples through them, over our heads, and our scuttling to a safe retreat. The apple trees never failed,- -for we forget the barren years and never knew the waste of finest apples at top of the tree that could not be reached even with the tallest ladder. The sprig of a tree we plant spans no more than the shade of one's hand; the old tree we remember seemed to brush the clouds. Now we keep the orchard low and let in the sun- 
light. Only unsuccessful orchardists put out sixtyfoot apple trees. ${ }^{x}$

Pear trees flourish in moist, rich, well-drained soil. They are usually short-lived and subject to many diseases. Of these the blight and the scale are familiar, making pear culture uncertain and unprofitable. Yet the orchardist who can control these diseases and raise pears has a profitable crop. ${ }^{2}$

The variety of apples as displayed at the annual exhibit of the Pomological Section of the Horticultural Society of the State is bewildering and each kind seems best. A general consensus of opinion indicates that for the States of the North and East, the best early or summer apples are Yellow Transparent, Early Harvest, Primate, Early Joe, Red Astrachan, Golden Sweet, Oldenburg, Summer Permain, Chenango, Bough (sweet), Gravenstein, Jefferis, Porter.

The best autumn,-Maiden's Blush, Bailey (sweet), Fameuse, Fall Pippin, Wealthy, and Mother.

Winter,-Jonathan, Hubbardson, Grimes's Golden, Tompkins's King, Wagener, Baldwin, Yellow Bellflower, Rhode Island Greening, Talman, Northern Spy, Red Canada, Roxbury Russet.

For the South and Southwest:

Early summer,-Red June, Yellow Transparent, Red Astrachan, Summer Queen, Benoni, Oldenburg, Gravenstein.

Autumn,-Haas, Late Strawberry, Maiden's Blush, Oconee, Rambo, Peck's Pleasant, Roman Beauty, Carter's Blue.

Winter,-Paragon, Shockley, Smith's Cider, Hubbardson, Hoover, Horse, Grimes's Golden, Buckingham, Jonathan, Winesap, Kinnaird, Ben Davis, York Imperial, Romanite, Rall's Genet, Limber Twig.

In the Northwest, extremely hardy varieties:

Early,-Yellow Transparent, Tetofski.

Autumn,-Oldenburg, Fameuse, Longfield, Wealthy, McMahan.

Winter,-Wolf River, Hibernal, Northwestern Greening, Pewaukee, Switzer, Golden Russet.

Of varieties as early pears,-Clapp, Bloodgood, and Summer Doyenne; as autumn pears,-Bartlett, Boussock, Flemish Beauty, Buffum, Howell, Seckel, Louise Bonne, Duchess (d'Angouleme); for winter, Anjou, Sheldon, Clairgeau, Lawrence, Kieffer, Winter Nellis, and East Beurre. At the North the Keifer tends to grow small, coarse, and stringy, and of poor flavor; it is better at the South. 
All diseases to which fruit is subject seem to afflict the pear tree. We are not as yet practically acquainted with the preventive of blight. The usual treatment for scale remedies that evil, but for pear blight we as yet can do no more than to cut out the affected part, a foot or so below the sign of the blight, and burn the cuttings. Leaf blight is hindered if not prevented by spraying with Bordeaux mixture. The best treatment of the pear tree is abundant feeding. Orchardists differ in opinion as to cultivation; many, and successful raisers of pears, insist that the orchard should be left in grass and be freely enriched with plantfood, barnyard manure, and with fruit-foodpotash. The dwarf varieties are more susceptible to disease than the large or standard varieties.

In the old days, land thought to be unfit for anything else, especially if wet, yet plowable, was set to plums. Yet the tree has its preferences and ever for well-drained, strong, rich soil. Plums divide into two classes, Domestic and Japanese; the latter newcomers which grow rapidly, fruit early and abundantly, tend to overbear, and are short-lived. This means that they are very susceptible to disease. The Japanese varieties blossom and set their fruit early and therefore are somewhat uncertain at the North. If raised there they should be planted on late ground that slopes to the north and where May does not come in March, or March in May. The variety of plums is somewhat bewildering, and whatever the or- 
chardist plants he will sooner or later doubtless wish that he had planted some other variety. Plums seem to be the favorite fruit for experimentation by the nurserymen. New varieties crowd upon us each year. The orchardist who raises plums for profit desires size, color, flavor, prolificness, and good shipping qualities. This may be truly said of the desirable in any kind of fruit. But a plum tree must always grow very near the market house; the fruit will not bear handling. By the time it is fit to eat it is too ripe to stand transportation. If shipped green, it suggests persimmons in July. Yet, conditions being favorable, plums are worth raising. If kept trimmed lowand the plum tree is a very vigorous grower-an acre of plums, say one hundred and fifty trees, of standard variety, but not a mixture of many varieties, will, when in full bearing - that is, when the orchard is fifteen years old-yield from fifty to seventy-five nine-pound baskets to the tree and give a gross return of from three hundred and fifty to five hundred dollars. The essentials for profit are large, well-colored, firm fruit of fine flavor, and a good market which may be reached, say within twelve hours. ${ }^{\mathrm{I}}$

Of higher value than the plum is the prune, which seems to be only a hardy, late plum. One

The varieties are legion, but by general consent, based on experience, the best domestic plums are Bradshaw, Lombard, Imperial Gage, Jefferson, Fellenberg, Shropshire, Monarch, Coe Golden Drop, Green Gage, and Grand Duke. Of Japanese varieties,-Burbank, Abundance, Red June, Satsuma. 
cannot easily distinguish a plum tree from a prune tree, but experience soon discovers the superior value of the prune. It is hardier, more productive, longer-lived, and more regular in bearing. Of prunes three desirable varieties are York State, German, and Italian, the first possibly a local "sport" or seedling, the tree strongly resembling wild stock. Maturing in late September, or mid-October, the prune is firm, large, rich in color and quality, and able to bear shipment to long distance. Some orchardists report an income of from five hundred to eight hundred dollars an acre from their prunes. The enemies of plum and prune multiply every year. Black-knot is most formidable and is cured by cutting out and burning the affected parts, even if the whole tree must go. The trees must be sprayed for scale, for fungus, and for other insects than the scale,-moths, curculio, and the like. Both plums and prunes tend to overbear and thus produce a mass of small fruit. The preventive is thinning out the fruit early in the season, rather than to let the limbs crash down under weight of superfluous fruit, or to rely wholly upon trimming. The orchardist who has many plum or prune trees must plan to give them ceaseless attention. They are highly profitable when rightly managed. Every fruit-farm needs fruit in its succession from opening summer till closing winter. By consulting the catalogue of a trustworthy nurseryman, the fruit-farmer may select a few plum trees as it were "for table use." The 
Japanese Abundance ripens in the Lake Shore Valley about the first of August, and by careful selection of varieties the farmer may have plums from this time till snow flies. He may well remember that one plum tree, well cared for, produces many plums. He may plant several varieties in order to have succession of fruit, but he will not plant many trees save of the variety which he knows will prove profitable commercially. Otherwise he will litter his land with fruit he will not know what to do with. He will have too much to use or give away and not enough to sell.

Peaches, next to apples, command the market, but no section of our country shows uninterrupted health of its peach orchards. The tree has many enemies. It is rather long-lived, as many still in bearing in the Valley have passed their first quarter of a century. During this period many varieties have come and gone. Weather rather than climate seems to determine the fate of the peach tree. The climate may be peach but the weather may prove "yellows," "scale," "black-knot," or some other evil in form of insect or fungus. The tree requires a well-drained, light, fairly rich soil. It is a rapid grower and needs vigorous trimming. Wet, heavy land is not for peaches. As one travels over America he will see more extinct peach orchards than of any other fruit. Varieties are legion and each peach area has its favorites of soil and climate, of grower and of consumer. In peaches as in plums, it is color, size, and 
quality that determine the selection of varieties. The rich yellow, crimson, pink, free-stone, firm juicy peach is always in good demand. Very early peaches are usually cling-stones, fair in color but rather tasteless, or even bitter. The money-making peach is the late, canning peach. The housewife never cans the early peach. She waits till the fruit shall be cheaper and suddenly discovers that the season is quite past and she has not yet put up her peaches. This makes a market for the later and, one may say, better varieties. ${ }^{\mathrm{I}}$

In planting peaches one must observe the same caution as in planting plums,- - one, two, possibly three standard varieties for commercial profit,say Dewey, Elberta, or Crawford, but never a mere mixture of varieties. An acre of peaches, or many acres, can be most effectively cared for if of one kind. The labor bill compels this economy. It is best to harvest a thousand bushels at one time than one bushel a thousand different times. There is money in peaches but not always in peach orchards. In the peach belt anyone can raise peaches if he can raise peach trees, successfully warding off yellows, curl-leaf, borer, brown rot, scale, root-gall, and the new diseases the summer may bring forth. The first question is whether your land lies within

One may prudently consult successful peach-growers as to varieties. The Crawford, early and late; Hale's Early, Alexander, Elberta, Oldmixon, Stump the World, Gold Drop, Smock, Early Rivers, Champion, Belle of Georgia, Captain Ede, Fitzgerald, Admiral Dewey, Foster, Morris White, Wheat, and Mountain Rose are standard varieties. A peach calendar may be made out, like the plum, so that the household may have peaches from mid-July until snow flies. 
the peach belt; whether you are under the true peach sky. If so, plant peach trees. Every orchardist in every peach belt in the country is confronted by the same question. While you are waiting, another is reaping from two hundred to six hundred dollars an acre from his peach orchards.

A cherry tree, like any other fruit tree will live, even flourish as a shade tree, where it will not bring forth fruit. But there are more desirable trees for shade than are cherry trees. The cherry likes a well-drained soil, not too dry or heavy. Like peach or plum it grows rapidly, and like all fruit-trees perishes quickly in standing water, either above or below ground. Like other fruittrees it makes its annual growth while the fruit is growing. If left to itself, leaf and fruit will mature together, the fruit clinging the longer. Here is the clue to feeding the tree,-both for fruit and for foliage.

Sour cherries or sweet? Which shall you plant? The sour are more regular in bearing; the sweet carry the higher price but are less hardy. Thus it may be said that while an orchard of sour cherries bears every year, it bears heavily on alternate years. Cherry trees, specially of sweet varieties, are long-lived, long-jointed, brittle, coarse growing, and susceptible to injury from wind, snow, and ice-storms; often break down badly in early spring when the sap is starting, and are quite likely to break, when winds are strong, under weight of leaf and fruit. To escape such injuries the tree 
must be headed low, and, if possible, the whole orchard should be sheltered by wind-breaks, by woods, or by the lay of the land. Of sweet cherries the standard are Napoleon, Elton, Black Tartarian, Oxheart, Windsor, Rockport, Yellow Spanish; of sour cherries, the Early Richmond, Montmorenci, May Duke, Reine Hortense, Kentish, and Morello. ${ }^{x}$ Early Richmond ripens first, Morello last, with an interval of a month, in some seasons, between first and last picking. Of sour cherries the Montmorenci is best, both for tree and for fruit. The tree is compact and a prolific bearer; the Richmond is a sprawling tree, weaving about in the wind and less prolific. The old-fashioned cherry tree by the kitchen door peeped over the roof and its best fruit was picked from the shingles on the tip-top branches. We are learning to head our cherry orchards low so that much of the fruit may be gathered while the picker stands on the ground, and the remainder from short ladders made for the purpose.

The care of sweet cherries and of sour is not quite the same. The trees have unlike habits and must be trimmed differently. Just how this trimming shall be made is also a matter of opinion. Some orchardists, highly successful with cherries, trim the sweet varieties vigorously, opening up the center of the tree to the sun, and cutting back boldly. Sour cherries do not readily bear such

Cherries are budded in the nursery on Mazard, or on Mahaleb rootstalk. Opinions vary as to relative value of these root-stalks. 
trimming and are more subject to sun-scald. But either tree should be trimmed with a knife rather than with saw or ax, and the orchardist's chief study should be to keep the tree low, well balanced, and free from trimming scars. Doubtless the best rule is, "Do as little trimming as possible."

The quince thrives in a rich, deep, moist, welldrained soil. Of late years it has become rare in some fruit valleys, having been quite eliminated by insects and fungi. The fruit is never in great demand. Some think that the disappearance of forests, woods, and wind-breaks, as well as the invasion of fungi and insects, accounts for the disappearance of the quince. The tree at best is an uncertain bearer and never very prolific. The orange quince remains a standard variety. But the orchardist, like the public at large, seems to have lost the taste for quinces. Ashes are excellent fertilizer for the tree,-unleached wood ashes. Trimming consists largely in removing dead and dying wood. The tree cannot be kept shapely like a cherry or a peach tree.

Grapevines, but not grapes, will grow almost anywhere in America. The extremes are vines as foliage plants and vines that fruit in fine quality and great quantity. This means that the grape areas of America, as elsewhere in the world, are sharply defined by climate. Here the law is "each after its kind." In rather a loose way, grapes may be described as raisin grapes and others, -that is, grapes that will dry and cure and grapes 
that will not dry. The former are known the world over as "layers." The non-raisin grape is of the temperate zone; the raisin grape is subtropical: the division is strictly climatic. In America the raisin grape area is in California; the table grape areas are numerous and widely scattered. One of the noted areas is the Lake Shore Valley, which includes the celebrated Chautauqua Belt, of western New York. In these days when young men are taking up horticulture as a vocation, as other men take law, medicine, or engineering, they will do as does the young lawyer or engineer,-they will go to the place where such business as they wish to carry on is done in the best manner and most profitably. Thus, as the years pass, the ablest and most successful fruit-growers will be found in the best fruit regions of the country. The non-raisin or table grape - the common wine grape of the country-comes to perfection at the northern margin of grape cultivation. Here they reach perfection of quality and quantity. This law of fruitage is common to all vegetable life. Quality may determine the commercial value of any fruit. This is true of grapes.

Left to itself the grapevine grows to extraordinary length, and ever tends to foliage rather than to fruit,-whence the vigorous trimming necessary in viticulture, for the art of raising grapes consists in converting superfluous foliage into superior fruit. You may have a hundred feet of vine and here and there a scraggly, small bunch of inferior fruit. Cut 
back the vine; restrain its growth; force it to fruit instead of to foliage and you have many large, compact bunches of superior fruit. The practical problem is to concentrate the vitality of the vine into fruit. But this is also the constant problem in the orchard; it is the basis of the art of fruitgrowing.

The first explorers of the Lake Shore Valley, La Salle, La Hontan, Charlevoix, two hundred and fifty years ago, took note of the abundance of the wild grapevines, along the shore of Lake Erie, running to the tallest tree-tops and hung with many clusters. The progeny of those vines is vigorous in the Valley to this day,- - creeping over the rocky bluffs of the lake, and hiding the lofty cuts and chasms,--locally known as "Hogs' Backs,"made by the sixteen streams, - of which La Salle makes mention, in the sixteen gulches which traverse the ancient Devonian hills walling in the Valley along the south. The wild grapevine will live anywhere in America except in the arid wastes, -the "Great American Desert" mapped out in the school-books of our childhood, but which has vanished with the "West." It yields to cultivation, like other fruit stock from the wild, and prospers best in deep, rich, well-drained soil. The vine grows in two sections, - one below, one above ground, their surface exposure in earth and air quite equal. Trimming the upper vine concentrates vitality in the roots and upon the fruit-buds. Every vine, capable of fruiting, buds to reproduce 
fruit after its kind. Very vigorous vines in a state of nature do this. Cultivation consists in modifying the habits of the vine. It has been said that all our varieties spring by cultivation from the wild vine. As a general statement this is true, but all our varieties do not come from the same wild vine, or directly from the wild,-but through domestication and crossing of varieties themselves. Occasionally a seedling appears having marked characteristics, and so fixed as to be capable of reproducing its kind. Commonly the strong tendency in the vine is to revert to the wild. The wild stock of one region of the earth differs from that of another. Transplanting from region to region and cross-fertilization produce varieties. The Concord grape was a seedling, but the chance that a seedling will develop a desirable variety is remote. Only a professional experimentalist,a Burbank, - can wisely attempt the problem of producing a new variety. The fruit-grower who wishes grapevines which will produce each after its kind, plants cuttings, not seeds, much as the orchardist sets grafted stock, not seeds of apple, peach, or plum. The seed reverts to the wild, save so infrequently as to make the rule practicable; the cutting and the graft remain true to stock.

The culture of the grape varies widely in different countries and in different parts of the same country. In the Lake Shore Valley and the Chautauqua Grape Belt, the vines are set in rows, eight feet apart in the row, the rows nine feet, though 


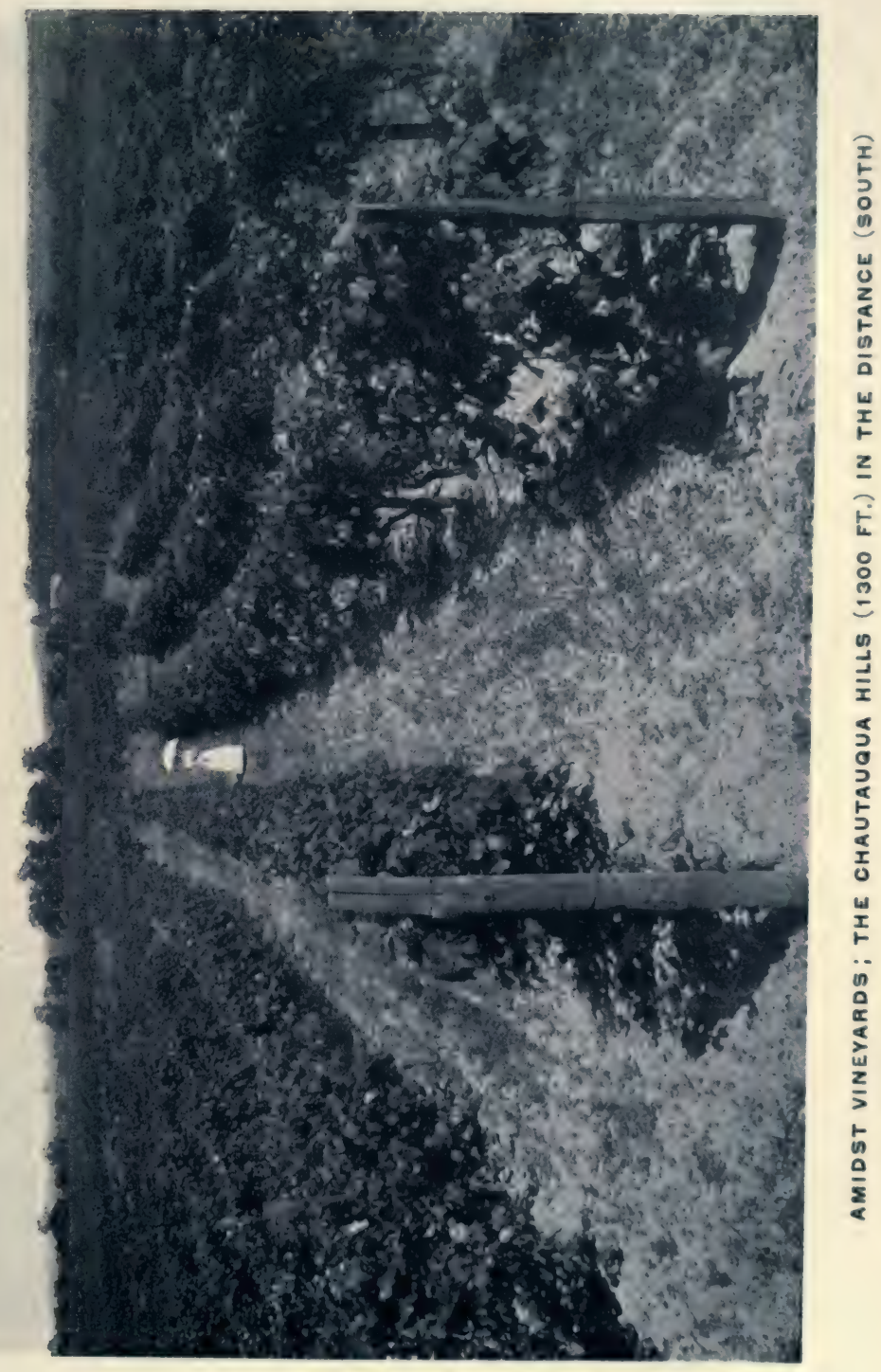



some set them ten, apart. The vine is trained on two wires, stretching the length of the row, the lower three feet, the upper, six feet from the ground. Each wire is drawn taut, is fastened securely to the post at the end of the row, and is also fastened by staples to stakes at intervals of twenty or twenty-four feet apart driven in the row. The vine is fastened to the wire with twine-a heavy hemp cut to length - or with wire. The hemp is cut long enough to tie readily; the wire, fine and flexible, is about three inches long. Fifty years ago vines were tied with willow, as they still are in Germany. The method was brought into the Valley by the Germans who came in great numbers shortly after the Revolution of I848. As the German skill has died out, and labor has become scarcer and more expensive, the use of the willow has ceased. The wire is convenient but is liable to cut the vine if it sways in the wind. The hemp cord has proved a practicable substitute for the willow, is easier to handle, and cannot injure the vine.

The end posts are well set and anchored either by bringing the upper wire over the post and burying in the ground, the extreme end of the wire wrapped about a stone, thus bracing the post in front, or by placing a brace in the row, behind the post,using a strong stake or a fence rail. The wire anchorage system in front of the post is objectionable because it interferes with the tools, catches the hames, and may be torn out as the team turns the 
row. The grape rows themselves are of the length of the section, and usually line up with the several rows in the succeeding section. In setting a vineyard it is expedient to have long rows and as few turns as possible. The weight of the wire with vines and fruit is great, often excessive under pressure of the wind. Old wires break; new ones may pull out staples, and the great weight of wire, fruit, and foliage may and often does break down the end post. The purpose of the stakes is to ease this weight.

Grapes develop in light, air, and dryness; if suffered to lie on the ground they never color or ripen. Vines must hang from the wires, not rest on the soil. Raisin grapes, as in California or Spain, will ripen near, or even on the ground, the canes on which they grow springing from a stub, or stock to which the vine is trimmed back every year. The vine of the Concord type is trimmed back to a point about three feet from the ground, the stock below as straight as possible. From the point where the stock reaches the lower wire the vine is trained to two arms extending in opposite directions from the point, each arm fastened to the lower wire. From each arm two canes are suffered to grow to the top wire, all other wood being cut away annually. Another system, called the umbrella system, trims away all wood along the stock to height of the top wire and at that point allows the canes to grow and hang down over both wires. The objection to the umbrella system is to 
the ever-lengthening stock, rising above the wires, for the stock, as it ages, acquires much loose rough bark which easily becomes the refuge for fungi and insects. The arm system, which prevails in the Lake Shore Valley, keeps the stock low and permits new canes each year. This year's grapes grow on last year's wood, so that in trimming provision must be made for a year ahead. By this system the strength of the root is annually concentrated upon the fruitage of buds on the four or more canes. These buds, stimulated to growth by trimming, fertilizing, and cultivation generally, develop rapidly into leaf, tendril, stalk, and fruit. The trimming of the vine determines the character of the vineyard and is doubtless the most important part of grape culture. The root stalk, growing constantly, tends to become a thick, heavy stump, having short stubs sticking out as memorials of the poor trimmer. These stubs split and crack at the ends, under sun and rain, and give entrance to fungi and insects,- - fertile culture ground for the countless spores ever floating in the air. To avoid evil results, the vine should be trimmed close to the stock, making a clean cut. Small wounds heal over, but large cuts must be covered over with some artificial surface that will exclude the spores,say, pitch or paint. The stock below the bottom wire becomes ultimately at the top a mass of scars. The trimmer allows a sprout to grow from the root and to take the place of the old stock, which he saws off and burns. By this procedure the vine- 
yard may be renewed and kept young. Vines may grow crooked stocks which interfere with the tools. These may best be supplanted by a new shoot. Again, the old vine may have what is called the "dead-arm," - that is, so diseased do the two arms become because of trimming and spores of fungi, they die even down to the ground and must be replaced by a new sprout from the root.

A grapevine naturally tends to fruit at the end, of course on last year's wood, so the clusters, in successive years, would, if the vine is untrimmed, form farther and farther from the root. The trimmer cuts back the vine and keeps the fruit near the stock, converting the vitality which would become length of vine into quantity and quality of fruit. Trimming is therefore the yearly regulation of buds. Experience alone enables the trimmer to know how many and what buds to leave for the season. He may suffer the vine to overbear, with consequence of little or no fruit the following year and a dangerous shock to the vine. The entire art of cultivation culminates in the shape, form, and fruitful vigor of the vine.

Of several hundred variety of grapes which will fruit in northern vineyards, less than half a dozen are of commercial value. In the Lake Shore Valley, and generally in the north, the Concord is the standard grape; the unit of measure of prolificness, vigor, hardiness, regularity in bearing, and of quality and quantity of fruit. If it may not be in every respect the best known grape, it is the one 
grape which combines the greater number of desirable qualities sought. It is a climatic grape, like every other, and doubtless flourishes at the northern limit of grape cultivation as can no other variety. Again, it may not be adapted to vineyards south of Mason and Dixon's Line, or in the California grape area. The practical question in any area is, What grape can be grown here, profitably, year after year? This means, What grape of first quality, will stand the climate, fruit abundantly, bear regularly, and always be in demand?

Whether for table use, or for wine, the Concord is unsurpassed. At the South Shore Wine Cellars I was told that from this grape every brand of wine known on the market may be made. The Concord has never failed in the Lake Shore Valley,-a record which cannot be claimed for any other grape, any other fruit, or any other plant known to the region. It ripens about October first and is harvested during that month. It will hang on the vine till spring and preserve some hint of its quality. There are earlier and later varieties: earlier,-Worden, Moore's Early, Campbell, and Delaware; later, Catawba and Isabella, but these two varieties have quite disappeared from commerce. The Niagara, a large white grape, ripens with the Concord; also the Agawam, Brighton, Hartford, and some eighty other varieties. But in planting a vineyard one must consider the end,which is to raise grapes at a profit. Varieties to suit the owner may be set, as it were, for table use, 
but not for profit. A variety of grapes becomes a nuisance, like a variety of peaches or plums. The vineyardist needs to raise grapes on a large scale, so that he may harvest them at one time, with economy of labor. Varieties compel irregular picking, variety of packages, and extra labor. If varieties are raised, let there be enough of each to make the effort a commercial success. Five rows of a variety are a nuisance; five acres may be profitable. In planting a vineyard, care must be taken to secure regularity; straight rows; vines set sufficiently deep so as to protect the roots, not alone from frost but from the teeth of the tools. In wiring grapes, the rows may well be run so as to escape the violence of prevailing winds-that is, with the line of storms, not across it. Thus if by mishap a hailstorm visits the region, grapes which row with the storm escape better than those which traverse its course. In the Lake Shore Valley rows running parallel with the lake are less likely to suffer from storm, - a serious matter when acres must be re-tied after a northwester. But the Valley lies at the confluence of two vast circulatory systems of the continent: the St. Lawrence, and the Mississippi, and in consequence storms spring up quite without notice from any quarter. Few of these storms are violent, and for a period of nearly fifty years vineyards have been injured by hail but twice. It is folly to set out grapes on land that is not grape land. The traveler through the Valley will see many acres of such folly. The 


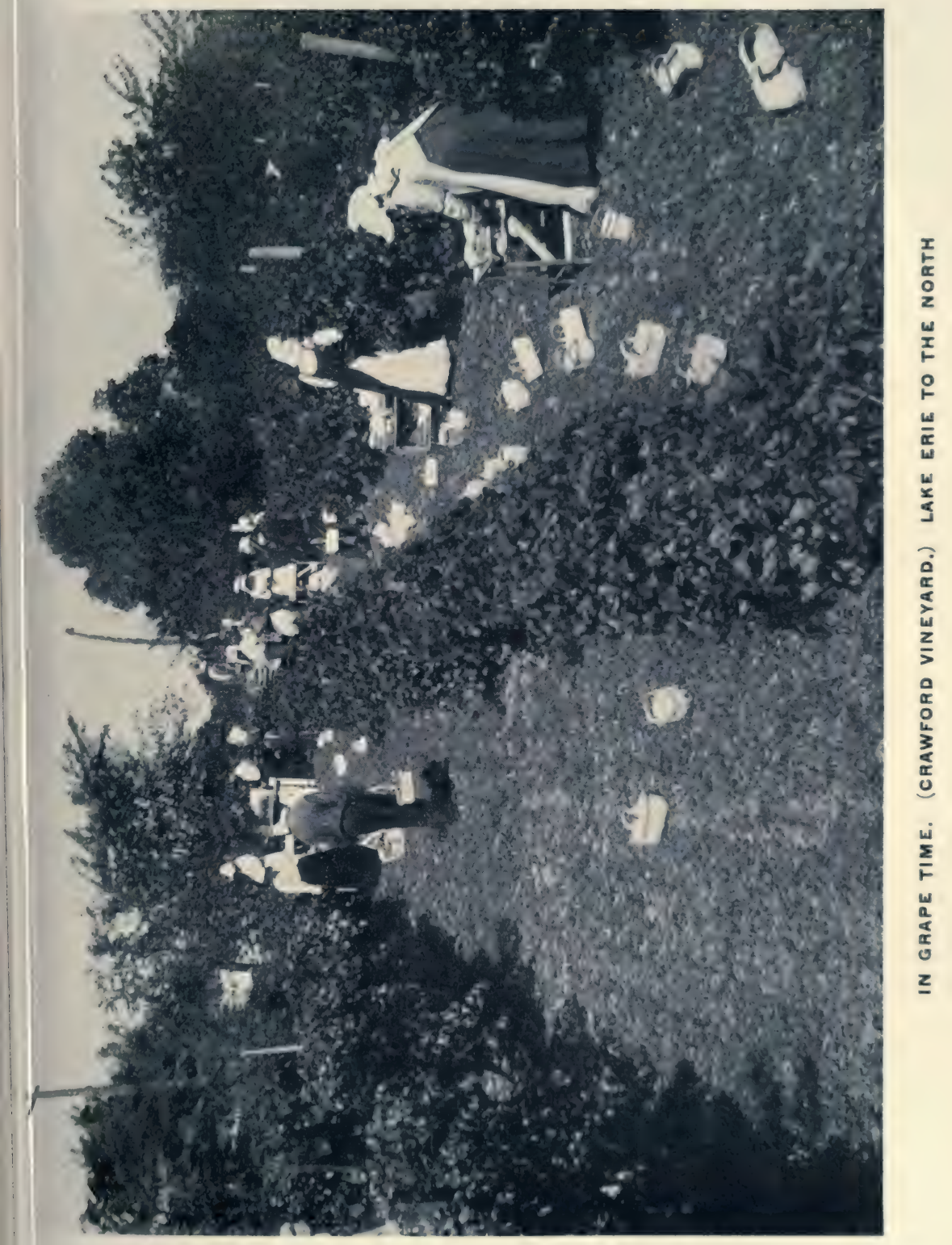



cost was too great and the vineyards have been neglected or abandoned. Nor does it truly pay to set a vineyard unless it is to be cared for ceaselessly, fed bountifully, trimmed wisely, and, in a word, kept at highest production. There are hundreds of acres of such fine vineyards in the Valley and the average yearly return-gross-for each acre is about one hundred and forty-five dollars.

Strawberries require well-drained, rich, moist ground. The supreme test is the growth of root, stalk, and leaf, provided the variety is self-fertilizing; if not, two varieties must be set, pistillate and staminate. A large, dark green leaf on a strong leaf-stalk means a large berry or cluster of berries. Irrigation is a temporary soil. The yellow root means health and vigor; the black root means age, weakness, and death. Repeated cultivation during the first season means fruit the second and is better than irrigation. Ceaseless hoeing of the strawberry bed raises the price of strawberries. This year's runners are next year's bearing plants. Plant the bed early; plant deep and set each root firmly with soil well pressed about the rootlets. The best strawberry beds are put out on rainy days in April. Late summer or fall planting is a sorry substitute for April setting. Strawberry raising is a special business and he who would succeed may well read the special Strawberry Bulletins issued by the Experimental Stations. Mulch the vines; keep them cool, moist, 
free from weeds and enemies, and you will have berries. In common experience the chief enemy is the white grub or cutworm, the larva of the ordinary August locust. It is said to spend seventeen years underground, and seventeen days as locust, during which it lays its eggs against another subterranean sojourn. Every locust stands for seventeen ruined strawberry beds. The only remedy is to set the plants where there are no grubs, and this means in soil that has been worked deep and thoroughly for several years. Repeated plowing of the ground throws out the grubs that they may be devoured by birds and the patient hen.

The strawberry plant is short-lived, for commercial purposes, and its fruit deteriorates after the first crop. Unless very near a good market, one better have a strawberry bed than a strawberry field. The crop must be handled quickly, at short distance from market, and with unusual skill, -if made profitable. The Marshall, Brandywine, Parker, and Eagle are, or were yesterday, desirable varieties; but each season brings new ones, more numerous than of plums or grapes. The desired berry is large, firm, of high color, of fine quality, odor, and taste. But the market demands a good shipping berry. Most of the best eating berries are poor shippers, and many good shippers are poor eating. So the fruit-farmer raises strawberries for his own table and strawberries to sell to city folk who may not know the difference. It 
is a profitable crop but requires patience and what Napoleon called "the ignominious love of details." On a fruit-farm it is most desirable to raise early fruits,-those that market in June, July, August, rather than in October and November. It is most desirable to get off fruit in good weather; to clear up the year's work as early as possible. Strawberries, raspberries, and cherries come early and are soon off the grower's hands. He gets his returns early in the season and is thus enabled to meet later expenses.

Raspberries, black or red, and of the red, the earlier or the later, properly set out, will run, as a crop, for a dozen years, barring destruction by blight, rust, and winter-killing. The ideal thing is to secure and to maintain highly vigorous plants. Raspberries bear the third year and usually regularly. Light, gravel, well-drained soil kept rich and moist produces fruit. But gravel land may dry out in May and June, or amidst picking time, and a heavier soil, a clay loam is better. No crop responds better to timely rains, which means that the root needs much moisture. This indicates the proper care of the raspberry patch: keep it well worked, stir the soil, irrigate with the cultivator. Nitrate of soda hurries up the growth of the canes, but barnyard manure or the best commercial substitute keeps the plant in vigor. The old canes must be cut out after the crop is picked. Running the cultivator through the patch during a drouth, whether or not the fruit is picked, 
will act as a rainfall. The Cuthbert, early or late, still holds its own as a red variety; the difference in time of ripening being about ten days, the later Cuthbert being the superior berry. Of black varieties, Kansas and Eureka are later than Conrath or Palmer. The Marlboro competes with the Cuthbert in favor. Anthracnose, a fungous disease, is the worst enemy of the plant, but may be exterminated by spraying with Bordeaux mixture. After seven years the plants seem to get weary of the ground and have passed their maximum production, whence the rule with many growers not to keep a berry patch in one place more than five crops. Dewberries and blackberries require like soil and treatment: the danger as before being that the farmer will neglect the patch and let the canes dry up. There is no remedy for the red rust, save to dig out the diseased canes and burn them. The dewberry is practically exempt from disease,- the best variety, the Lucretia.

Of blackberries, the Snyder, the Wilson, the Taylor. Some farmers plant raspberries, blackberries, or dewberries as a catch crop between the rows of young orchard and run the patch till the orchard begins to bear. The practice is not to be commended. Potatoes, corn, beans, carrots, turnips, strawberries may be so planted, but never berries borne on canes. The raspberry root is like that of a tree and the plant exhausts the soil over an area of several yards. One cannot raise two spears of grass on the same spot, much less a 
cherry tree and a raspberry bush. The bush will gain on the tree; the berry-field, on the orchard. You are robbing the orchard while raising berries, nor can you fertilize the ground for both orchard and raspberries. The raspberry roots are persistent and can be exterminated only after costly labor, running through years. Your trees will suffer, and you started to raise an orchard not berries; therefore give the orchard the right of way. A passing crop like potatoes, or any hill crop, even strawberries which last but two years, may be suffered, but do not neglect to fertilize both for the cover crop and for the trees. At best it is a doubtful venture, and when your orchard is at last in bearing, you will regret if you delayed and stunted it by a cover crop of raspberries, and will rejoice that you gave it the land.

Currants and gooseberries demand rich, moist, well-drained land. England and central Germany-cool, moist regions of the earth-are the paradise for currants and gooseberries. America is too dry for the best fruit of this order. Yet, if they can be grown, both fruits are profitable. The care of the bush consists in cutting away dead branches and superfluous young ones. The fruit comes on the old canes and one must therefore trim with discretion. The enemy comes like a thief in the night,--borer, leaf blight, and currant worm. The astonished farmer discovers suddenly that his bushes are bare sticks. Before the blossoms, spray with a weak solution of Paris green; 
after the fruit forms, with pyrethrum, a tablespoonful in a gallon of water. This disposes of the worms. For leaf blight use Bordeaux mixture, applied carefully and not too strong; for the borer, cut out the bush, root and branch, and burn quickly. All currant bushes are susceptible to disease. The standard varieties are Fay, Chautauqua, and Cherry, but there are others. The Victoria is considered most hardy. The Black Naples will make dark currant jelly and is a prolific producer. Gooseberries always call up vistas of English gardens, tarts, marmalade, and things generally sour, but the berry is gaining friends in America and proves highly profitable. Keep the plants moist,-which means constant cultivation and mulching. If spraying is necessary while in fruit, apply an ounce of sulphide of potassium in three gallons of water. But fungi are best kept off by assiduous cultivation of the gooseberry patch. The Downing is best adapted to America, as the Triumph, Lancashire Lad, and other European varieties are subject to mildew.

In the Lake Shore Valley reports are made of large profits from strawberries, raspberries, currants, and gooseberries. Experience has taught the folly of setting many varieties; one or two suffice, and the acreage should be large. One holding of sixty acres of currants is known. The returns per acre for raspberries have reached six hundred dollars gross, and more for gooseberries. A fair average for a carefully tilled field 
would be, one year with another, about four hundred dollars.

In planting the fruit-farm it is best to plan generously, giving each fruit its exclusive acreage and management according to its own nature. The profitable fruit-farm refuses to be mismanaged long; it pays or ceases to be a fruit-farm. One can raise plants, trees, vines, shrubs, roots of all kinds,- - but this does not mean fruit. It is fruit we are after, not trunks, stems, stalk, and leaves. We plant the fruit-farm for fruit. As the military man would say, that is our "objective." There are several essential elements in our planting: climate, soil, drainage, selection of varieties, time of planting, manner of planting, and trimming the new plant. Once the stock is set out, our work has only begun.

We will therefore suppose that the site for the fruit-farm has been within the fruit belt, in whatsoever part of America, and that the facilities for marketing have been duly considered. The welldrained land has been laid out into appropriate sections. The farm is unified by well-made roads and alleys. The question of varieties has been duly weighed; you have decided precisely what fruit you will raise. You have obtained only standard varieties from dependable nurserymen and have planted your trees, your shrubs, your berries, and your vines in the right way. You have provided for ample cultivation; assigned sufficient space for teams and tools; have avoided useless 
turns; have not crowded your planting but have well considered prospective spread of root and top, for mature, abundant fruitage. You have given yourself sufficient space not merely for cultivation of the plants but for administering all the business connected with them,- for ingress and regress of teams and wagons and for the economical handling of crops. You have considered well the problem of housing man and beast, tools and fruit. You have, in brief, to the best of your ability, after adequate examination of authorities and a decent respect for experience, obeyed the principle of horticultural economy, in buying land, in planning your plantation, in setting out your fruit of all kinds, and particularly in restricting yourself to few varieties. You have assembled your farming machine. Now it remains to run it productively. 
GETTING ALONG WITH HELP

$A^{\mathrm{T}}$ the bottom of fruit-farming is the labor question: somebody must do the work. Whatever the labor question that bothered our grandfathers, it is our labor question that bothers us. "How can I get the work on my fruit-farm done?" There is only one solution to this problem: Make the work so profitable that it will be desirable to the persons you want to do the work. This is the only hope, not alone for the fruit-farmer but for every other employer of labor. But its realization is not easy. Walpole's dictum, "Every man has his price," is true in farming. Possibly the price is prohibitive to you; if so, you will not long run a fruit-farm; you will close the farm just as the manufacturer closes his factory. His machinery speedily rusts into uselessness. Your farm quite as speedily runs wild. Both are ruined. But men must live; the laborer must labor, and every man is or ought to be a laborer. The farmer must farm, the manufacturer manufacture, or "chaos and dark night."

Laboring, working, is not only the result of a 
state of industry but of a state of mind. After all it is a psychological question. And here it is best to see clearly and straight. Labor is the supreme necessity of the fruit-farm. The wage of the laborer is his return for the use he makes of himself. What is his most profitable use? Is it as he sees himself or as you see him? Essentially it is as world-conditions regulate matters. We are all prisoners of conditions, limitations, needs. Neither he nor you alone determines these. You as a fruit-grower depend upon the world-market; he as a laborer depends the same, through you, or whoever employs him, or gives him an opportunity to contribute to that market. The market conditions regulate the number and the wage of laborers in any activity. Farm work requires judicious planning in order to be successful. Horticulture is special farming. It is not "light farming," one room and a fireless cooker. Its risks are greater than those of general-farming; its returns are larger. Its labor shares in its conditions: greater skill and larger returns. But all labor on the fruit-farm is not expert. Indeed, most of it is unskilled, or at least is labor which any person, physically able to work, may readily do. It is of its kind and is regulated by demand and supply of its kind. Being unskilled, it is in general demand and therefore brings a general wage. But fruit-culture, being a special form of agriculture, requires labor of general skill for a special purpose, which tends to the limitation and selection of the 
labor and therefore to a higher wage. Being a regular and acknowledged form of agriculture, it gives regular employment, but while, in the aggregate, continuously, few of the laborers are required all the year round. It is labor of its kind in season. In spring, the cultivation begins in April and runs, say, till mid-August. In late June, in July, August, September, October, November, there is fruit to pick, pack, and market. In winter, that is between harvest and spring, there is the trimming of vineyards and orchards, cutting out old berry brush, and tying grapes; also the application of some commercial fertilizers to the land. But much of the work on the fruit-farm concentrates within well-defined limits of plant growth, fruit growth, and harvest, adding the pruning season which varies somewhat according to the pressure of work on the farm. The work is of different kinds. Only an expert can trim orchard or vineyard, but children can pick berries, and any person of ordinary skill can pick grapes, plums, cherries, peaches, prunes, and apples. Horticultural work therefore demands a relay of labor, but not continuously; consequently the laborer must do much within a brief working period. This means piece work and relatively high wages, or no one will find such work desirable. To the owner of the fruit-farm all work is desirable, because if successful it is profitable.

The labor question is largely one of locality. A fruit-farm near a populous center can always 
secure labor. It may not be, it usually is not, skilled, or even experienced labor, but the art is soon learned. Transportation of the laborers must be provided; they expect to be carried to and from their homes to their work. If this is not provided, they straggle in at all hours and the work is delayed. Transportation means teams and wagons, drivers and expense. The fruit-farm may house the laborers during the season, as of berries, cherries, grapes, or peaches. This means conveniences for bed and board and social and moral responsibilities. If the fruit-farm is favorably located for a supply of labor, it has not only independence but additional monetary value. Its owner may the more insist on skill, conduct, promptness, which otherwise he could not hint at, save at the risk of suddenly losing his help. Therefore in selecting a site for a fruit-farm, primary attention should be given to the problem of the supply of labor. On the well-managed farm the same workers find employment year after year. They are treated fairly and generously and, if honest and square, will take a deeper interest in the farm as a permanent source of income. It is transitory help that costs most and is least productive. The ideal fruit-farm has its clientele of help which accounts it a steady asset. There is mutuality of interest between fruit-grower and fruitworker.

Here may be realized the wisdom of fair, open, just, generous dealing,- - not of course wasteful, 
nor the payment of spasmodic prices which always cause the small fruit-growers apprehension. Labor always prefers the larger field as well as the higher price. Yet workers know a good thing and will come to the man whose fruit-farm is best managed, best equipped, and most productive. It is always the poor manager, the poor fruit-grower, the man of light crops, who has greatest difficulty to secure adequate help. Things breed after their kind; the best workers will always be found on the best farms.

The whole matter hinges on the character of the manager and the conditions he imposes. You yourself decide the labor question. If labor cannot be had "for love or money" then you must close out. But love of money will work the farm. Right here, however, is the fundamental: Is there enough money in fruit-farming to pay the labor bill, the expense of administration, and to leave enough for a fair interest on the investment? This is more than a local question in the Lake Erie Valley. Railroads, canals, corporations, legislation, tariffs, employers' liability acts, combinations in restraint of trade, strikes, epidemics, wars, disasters by sea and land, the market,-all affect the fruit-farm. One may be able by reason of location to raise tons of fruit, yet be precluded by adverse conditions from realizing a penny on his crop. This may be said of any business. So far as concerns labor, we all hang or fall together. We cannot escape the conditions of industry. 
Fruit-growing is a plunge into the game of living; it is sometimes a gamble. We can only play according to the rules and abide results. The laborer in the field or the President in the White House can do no more.

The young man who is contemplating fruitgrowing as a vocation will find himself in the same world as he who takes up manufacturing, engineering, or one of the black arts-law, medicine, or theology. The fundamental question with each is, "Am I supplying anything the world must have?" It is the problem of securing a dependable clientele, or, in other words, a steady market.

Does the world want apples, cherries, grapes, currants, strawberries, prunes, peaches?

Can you raise them?

Can you deliver them to the market?

Do you want to raise them and deliver them?

Do you want to do this more than you want to do anything else?

Or would you just as soon make shoes? Or clerk in a store? Or keep books? Or ring up fares in a trolley-car? Or practice law? Or preach? Or run for office?

"'Tis in ourselves, not in our stars, that we are underlings."

The world will always eat fruit; indeed, in America the fruit-eating habit is spreading. Our hundred millions will soon become hundreds of millions of inhabitants, and each will eat fruit. The land area is not increasing. Fruit regions 


\section{Getting along with Help}

are limited both in extent and in number. The proportion of demand of fruit to supply must increase. Fruit-growing as an industry is as stable as any branch of farming. Contrast it to foxraising as undertaken on Prince Edward's Island. Will black fox always be in fashion? Will fruit always be in fashion? May fashion change in preference for silver fox skins? Will people drop out fruit for meat and cereals? Or will they consume fruit for health as well as because of the cost of cereals and meat?

Here are some of the fundamentals to be weighed by the would-be fruit-grower. At present every vocation that can be called old is crowded and the rush for the new portends a speedy supply. There is now a rush for the land-a "return to the soil." The explanation lies in the ceaseless struggle for existence. The land question is the great question for all the world-the very great question in every civilized country. Land-grabbing is the history of nations. The land means a livelihood, therefore, get land. Old-fashioned farming lingers somewhat in ill repute; newfashioned farming means millions of money invested by syndicates and mere stock-holding, as evidence of claims to participation in profits from the land. "A fruit-farm for me; a neat sort of life; a bank account," is the dream of many a young man now surveying his hopes.

Farming, like many another large activity, is breaking up into special activities: dairying, stock- 
raising, poultry-raising, duck-farming, truck-farming, mushroom-raising, fruit-growing. In the old days one farm attempted to do all of these; to-day, one farmer raises wheat; another, vegetables; another, berries; another, peaches; another, grapes; another, cherries; another, apples. The day of the division of labor has reached the land, just as it long since reached engineering, law, and medicine. Each new agricultural specialty is an undiscovered country; a new world, which the young man, alive to his opportunities, hastens to exploit. Turn to the catalogue of one of the great universities and note the division and subdivision of instruction. The story is told of Cornell University that in an early day, President White, who was far ahead of his times in matters academic, wrote to a certain professor at Brown inquiring whether he would accept the chair of History, or Political Science, or Economics. Promptly came the reply, "Yes, all." The President is said to have informed the accomplished professor that the Trustees had established a chair, not a settee. Farms are becoming chairs and ceasing to be settees. Specialization in farming is only one aspect of modern industrial life. Whatever the specialization on the farm, it is a vocation which demands expert knowledge, and because it demands such knowledge it is a vocation. Old-fashioned farming was a general occupation; the new farming is a special labor. And deeper than this, farming, as the world is beginning to realize, is a very difficult 
business, demanding other knowledge than mere rule of thumb. The earth, the soil, is a chemical laboratory whose operations must be understood if the supply of food is to equal the demand. The world must starve on old-fashioned methods of farming. Here again it is "grinding necessity" that calls men back to the land. The truth is that we know very little about the land as the producer of food. We have here and there slightly scratched its surface, exhausted its vitality, and ignored its chemistry. By chemistry we do not mean a shelf of dirty bottles filled with mysterious fluids which burn, or of boxes of curious salts which unexpectedly explode. It is not a case of freshman chemistry. We mean that the earth is a storehouse, a laboratory of infinite resources. Everything from the soil; everything back to the soil,- - this is the cycle of the world before our eyes. Whence follows the fundamental importance of the soil. And this importance, recognized however partially in our day, explains the present interest in all forms of farming.

Then too, in our day, our country is no longer isolated, or its numerous business centers and local markets inaccessible; the railroads, the trolley lines, the automobile bring the American world together. Youth loves companionship, not solitude, and the fruit-farm of to-day is a suburb. Women set the pace of life and diversion is within reach of the farmer. Excessive urbanity, if I may use the word as meaning city-ness, wearies, yes, 
wears out its votaries, and human nature revolts against too much-or too little-evening dress. The strain and stifle of big business, filtering down upon clerks and employees, leaves an insatiable yearning for the poise of the country. Nature will have her own. Yet there is quite as much sanity in city as in country life; the lines of least resistance lead to the country rather than to the city; to the fruit-farm rather than to the clerkship in a down-town office. Salaries are low; the cost of living, high; promotion, slow; the prizes few and mostly bespoken by favorites of fortune rather than by the Girards, the Stewarts who to-day are keeping books or handling the yard-stick. The freedom of the country has greater charm than the freedom of the city.

Then, too, there is profit in fruit-farming,- - not the sudden profit of the oil-regions in the old days; or of the mines; or of the Stock-Exchange, but the steady, reliable profit of a sound business eminently respectable. Thus the fruit-farm seems along the line of least resistance to the young man of energy and specially to him of uncertain health. Wealth accumulates and men decay, and the delicate sons of fortune now seek health in orchard and vineyard. America is now old enough and rich enough to turn to fruit-farming. The Old World has been trying it for centuries. Cato, who wrote on farming nearly two centuries before the Christian era, reads like a modern horticultural writer; and this because farming, real farming, never grows old. 
It is a classic labor, and the classic, whatever its form, is immortal. Before many years the available fruit-land of our country will have been taken up. Chemical and horticultural knowledge will in later times, and yet at no very distant time, turn to land now ignored, and convert it into fruitplantations. It is improbable that any fruit-land will be abandoned. On the contrary, the best located fruit-lands will increase in value, though not, relatively, in productive power, save as intensively cultivated. This is the condition on the continent of Europe, and notably in Germany. Pressure of population means necessary intensive cultivation of the land. The problem of fruitgrowing is therefore one of knowledge, increasing with experiment and experience.

The fruit-grower depends upon labor; without it, soil, productivity, location, are as nothing. Fruit-growing is a special business and requires expert knowledge in the grower. Here it is the attitude of the grower towards labor that largely determines the labor question. In America, as the years pass, there is less and less disposition for one man to work for another. The relation between employer and employee is more or less strained and the tension makes or mars the crop. As yet labor has not learned that it may not become the employer rather than the employed. The very easiness of life in America has bred our labor difficulties. No man is willing to settle down for life as a laborer. The rise from poverty to 
riches, of employee to employer; of day laborer to owner of the plant, is a familiar tradition; infrequent in fact, and more familiar in the past than it can be in the future. Fundamentally it is a question of natural resources. So long as there remain undeveloped resources, of magnitude, in America, such as was the entire continent for generations, the transition from poverty to riches, conspicuous in the iron and steel, the lumber, the copper, the coal, lead, and oil interests in past times, may confidently be expected. The chances diminish in geometrical proportion as population increases. This is the history of all older countries. All men in America believe, or profess to believe, that they are born free and equal, but no man believes that he was born to remain a mere, unskilled laborer. Granting full scope to the doctrine of equality, we know by observation, and doubtless by experience, that all men are not born to be employers of labor. In other words, it does not appear that all men in America are born, industrially considered, very differently than are all men in other civilized lands. But it does appear, in every country, more and more as time passes, that the station in which a man is born is the station in which he will live and die. This is inevitable. All the phenomenal rise of captains of industry, multi-millionaires, favorites of fortune and of Congress, characterize this our earlier national history,-if the word national can be so applied. The trend, the world over, is toward fixidity of 
conditions. There remain no continents to explore; the opportunities which were distinctively American, cannot recur. Democracy moves ever towards the goal of fixidity of privilege, because it moves toward equality.

Fruit-growing is one of the opportunities of the present, as was the conquest of Mexico by Cortes and his band in the past. Specialization always means an opportunity for labor as well as for capital. In a new specialty wages are always high. They are high to-day in horticulture. So long as fruit sells for good prices, the "labor question," as the phrase goes, will not embarrass the fruit-farm. Break and scatter the fruit-market and wages on fruit-farms must fall. Strengthen the market; establish the fruit-eating clientele; get all our people to consume many times their present consumption of fruit, and wages on fruit-farms will rise. The wage problem on the fruit-farm is the problem of supply and demand; of expert service and of unskilled labor; of widening or decaying markets; of the habits of our people, whether they become and remain notably a fruit-eating people. The laborer is but one cog in an immense wheel; he is not his own master no more than is the fruitgrower. World conditions crib, cabin, and confine both employer and employee.

Facing present conditions, or the aspect of these which we interpret, the prospect is of betterment. As yet we have not begun to raise, much less to consume, fruit. Our climate compels us to eat 
fruit as an essential food. Ours is a stimulating, a trying, an exhausting climate, variable, changeable, capricious, wet, dry, hot, cold, - a climate of sudden extremes. In some American valleys a change of forty degrees in forty-eight hours is not uncommon at any season of the year. This is due to location,- - the valley lying, for instance, like that of Lake Erie, along the edge of two vast basins,-the St. Lawrence and the Mississippi. But America as a climatic world is the home of petty tumult, revolts, revolutions of heat and cold, of drouth and rainfall. Grinding necessity will keep us a temperate - that is, a non-alcoholic people. The alcoholic peoples inhabit the British Isles, Scandinavia, Russia at the north. These regions are not a fruit-land as is ours, or as is southern Europe. Germany, France, and Italy are less alcoholic than England, Scotland, and Ireland. Switzerland resembles England, as does Russia, Finland, and northern Hungary. But all Europe is less a fruit-country than is all America. The time is not far away when our country will be exporting to Europe all our fruits that bear carriage. Europe will import wines from America,-an importation already begun. Paradoxical as this may seem, it is written in the law of climate. Florida, Texas, California, and other vast and favored fruit-regions of America will monopolize the world's production of oranges, lemons, grapefruit, figs, olives, raisin-grapes, wines, dried and canned fruits. Already America, including Canada 
and its neighbors, monopolizes the apple-trade of the world.

This means that our fruit-market is a worldmarket. There will be no exception: apples, peaches, prunes, cherries, apricots, English walnuts, chestnuts, pecans, hazel-nuts, and berries of all kinds. The outlook therefore is encouraging for the fruit-grower. Labor seeks opportunity, and fruit-raising will give more and more employment to labor, at fair, if not at high wages. Fruitgrowing will become more and more a profession, a business, demanding expert preparation and service. And expert labor of any kind is always well paid. The market being the world-at-large, the demand for fruits must increase. Americans who have traveled in all lands have remarked again and again on the presence of American foodstuffs, - canned goods, prepared fruits, of familiar brands. The Arab in the desert breakfasts on fruits prepared and preserved in American factories. Sailors in seas most remote are served American-made foods. Savages-the curious few who remain-barter skins, feathers, and totems for a jar of Pittsburgh pickles. The price of fruits as compared with that of other foods must remain fair, and the fruit-grower must therefore pay fair wages for labor.

All transportation companies will consider the fruit-grower, not altruistically unless compelled to; but the aggregate freight to be hauled from orchards, vineyards, from berry and truck fields 
is incalculable. Of course the fruit-growers must look out for their own interests, but the large fact remains that they have interests worth considering. The railroad is competitor for the profits of fruit-growing,-and in a peculiar sense a favored competitor. Fruit must be moved when ready for market, if to be sold fresh. The canning of fruit prevents railroad monopoly of profits in fruit-raising, but seldom does a fruit-grower can his crop. His business is to sell directly from the tree and quickly. Some years ago, at the opening of the century, the necessity for spraying fruit was apparent in the Lake Shore Valley. But spraying seemed a formidable, not to say an unprofitable undertaking. The fruit-growers turned to the State Legislature for help. Influence was desirable and the Pennsylvania Railroad was appealed to. The head of the freight department promptly expressed his willingness to coöperate, "because increased crops mean more stuff for the road to haul." Trolley-lines, railroads, steamboats, ever stand ready to "haul" for a consideration. All middlemen, all manufacturers of packages, crates, boxes, and baskets; all manufacturers of wire, nails, labels, string, stamps, inks, hooks, staples, and of chemicals for spraying; all dealers in horses, mules, wagons, tools, and harness, and so on through a long list, have a fellow feeling with the railroads,-if a railroad can be said to have feeling. If we pursue the list of interested parties to the end it will be found to include the laborer also,--indeed more,- 


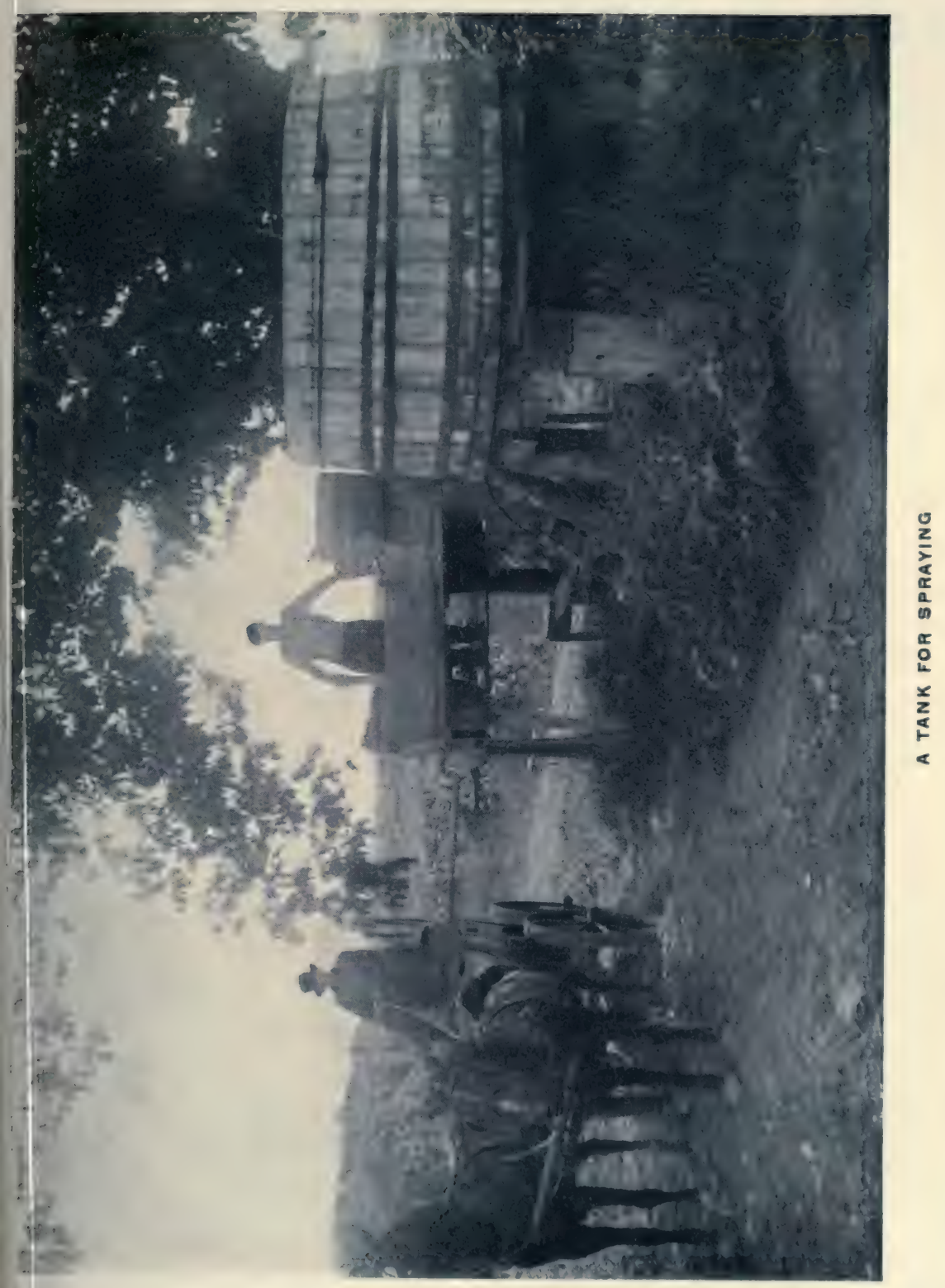



to include quite all sorts and conditions of men. Directly the fruit interests of the country are imperilled by insect or fungus, or by commercial discriminations, or by governmental folly, or by the even greater folly of ignorance among fruitgrowers themselves, then it appears how important are these interests to the world of labor. And yet there are always men and women to be found who are in a hurry to kill the goose that lays the golden egg.

In recent years both Congress and the State Legislatures have enacted many laws vitally affecting farming in all its branches. Granting that the general purpose of this mass of legislation is for the betterment of all people, nevertheless some of this legislation has been distinctively hostile to the farmer. $\mathrm{He}$ is the basis and foundation in our economic structure. It is right and proper that he put up sound fruit, that he give full measure, that he mark his products so that the consumer may know precisely the quantity, quality, and variety he is buying. The so-called "Pure Food" "Employers' Liability," and "Package" laws have this desirable end in view. But these laws are not infrequently drawn by men who have no practical knowledge of farming, whatsoever branch may be affected by the law. It follows that hostile legislation-perhaps unwittingly enacted-places the farmer at a great disadvantage. For instance, it is desirable to have an employers' liability act for all occupations more 
or less dangerous. But as our Supreme Court has read the word "reasonable" into the Sherman Act, we may conclude that an unreasonable law is no law. Farm labor is entitled to protection. The negligence of employers, when farmers, must be checked as among other employers. Rotten ladders, vicious horses, rotten harness, wagons, barn-floors, and the like exist by the culpable negligence of the owner. But the laborer must also take care. Is the farmer responsible for the accident which befalls an employee who ignores all counsel as to danger? Should the land, the farm itself, be made answerable for such culpability and the farmer by law be denied any defense? Has the farmer a right to show that he was not in any way contributory to the injury received? Should it be the presumption of the law that the farmer is guilty of contributory negligence and, as in the old English law of libel,- " The greater the truth, the greater the libel," the more serious the injury received by the employee, the greater the negligence of the employer? Farmers seem incapable of organizing for their own interests. The labor question is, after all, the great practical question in fruit-farming. 
THE CULTIVATION OF THE FRUIT-FARM

CULTIVATION of the soil is keeping its drainage system - that is, its circulation - in order. The circulation of the blood in our bodies ceasing, life ceases. The circulation of soluble plant-food in the soil ceasing, plant-growth, plant-life cease. So long as the plant is growing and ripening its fruit, cultivation furthers growth. But we must remember that we do not raise plants as does Nature in the wild. We demand as food the fattened leaf, root, bulb, tuber, stem, stalk, or pulp. The grape-seed, or fruit proper, is useless to us; the juice and pulp are food. We cultivate the fruit orchard, or the vineyard, not for seed, but for pulp. Therefore all our labor is concentrated upon doing, quite abnormally a mere part of the whole which Nature undertakes. We eat the pulp of the fruit and cast the seed away, as of cherries, peaches, plums, prunes, apples, pears, apricots, grapes, berries of all kinds, currants; not the fruit or seed of potato, turnip, beet, or radish, but tuber, or root. The whole problem of fruit-culture is to con- 
centrate plant-growth at one stage, or in some part of plant-development.

We are fattening the goose, not for eggs, but for swollen, overgrown livers. We raise ostriches for feathers; we grow vineyards for juice and pulp, not for grape-seeds. Our problem then is to deflect the vitality of the plant toward the abnormal overproduction of a particular part or organ. We are ever breaking the balance of the plant's life. This emphasis on the part accounts for many, if not for most, of the diseases of our cultivated plants. Rarely is a plant in the wild diseased. There, it is true, only the fittest and favored survive, but the millions that perish die of starvation, not of disease. Cultivated plants die of disease brought on by overfeeding, or weakening one part at the expense of another. Thus dwarf varieties of fruit are always less hardy than the normal stock, and shorter-lived. The three hundred and more varieties of grapes are three hundred and more times as susceptible to disease as the wild vine. There is a law of compensation that runs through all fruit-growing: the more delicate the quality and gross the quantity of a fruit, the more liable is it to suffer from disease. The so-called "finest varieties" are rarely hardy.

It is best to understand at the very outset in fruit-growing, that we are engaged in a somewhat artificial business. We seek to produce our kind of fruit, whether or not it is Nature's, and yet we demand that the tree or vine shall maintain its 
health. We stimulate men to propagate varieties of fruit which emphasize, exaggerate, overdevelop some quality or aspect of the plant at the cost of atrophy of some other part, and usually of all associated parts. In other words, in fruit-growing we are aiming at a very fine, possibly a very obscure, mark on the bull's eye, and insisting that this is our true center. We are particularizing, specializing, propagating leaf, stalk, or seed-pulp, at the expense of the rest of the plant. We must therefore follow strictly a particular procedure, or we shall fail of our particular purpose.

In fruit-culture all is included in the care of the plant. This care means the concentration of the plant's energies upon the production of what we want. We are tampering with the plant's balance of powers. This we do by budding, grafting, trimming, and feeding the plant. But in order to make plant-food available we must keep the soil drained. This we do by cultivating the surface. There is only one rule in cultivation: Early and often.

Budding and grafting are expert work done at the nursery, rarely on the farm. The fruitgrower's work begins with trimming, or pruning, as a means of concentrating the vitality of the plant upon the production of such fruit as he wants. The best orchard or vineyard or berry patch always looks young, thrifty, strong in latent vigor. The orchardist trims with a sharp knife and a fine saw and never cuts off a large limb save 
of necessity. A storm breaks down the tree or disease infects a limb. Then we do as best we can, and may be obliged to cut away a large limb. This shocks the tree, possibly even to death. Disease in the form of myriads of spores of fungi, at times floating in the air, promptly enters the wound. To prevent this we seal it against such invasion by a coat of tar or paint, which will resist wind and weather. If the scar is not too great, and the tree too old or too weak, the wound will heal over under an ample growth of bark. But we must not keep the tree ever healing scars. It is like keeping a man in hospital. In cutting the limb we make the cut at an angle to shed water, and as close to the body, or main stalk, as may be so as to give the tree as little healing to do as we may. Bad trimming kills as many trees, or makes them unfruitful, as do fungi or insects. The art of pruning cannot be learned wholly from books. It is the tree we are conserving. Nowadays we train our fruit-trees to head and fruit low, for ease in harvest. We head them back at every trimming; we admit sunshine from circumference to center and seek constantly to secure short, straight, strong trunks, with branches well balanced to the four winds. The rule is to keep the top in balance. The time to trim is when your pruning knife is open and sharp and you see what should be done. Winter, the leafless time, is usually when the trimming is done, and chiefly because the orchardist can then best attend to it. In summer the 
chapter of accidents is written by wind and storm (even as in winter) and you must cut out bruised branches. Doubtless the best time to trim is at any time after the fruit is picked and before the tree starts growing in the spring. The order in trimming is sprouts, twigs, branches, limbs. Note the order. In cutting off either, you concentrate what remains upon the work you want done.

Do you want quantity or quality of fruit? You trim accordingly. Trimming off branches or thinning the newly-set fruit is the same thing in kind. Nothing is gained by over-fruiting. Some trees, under our artificial orchard life, will fruit themselves to death. Nature takes a preventive hand in the game by blowing off thousands of blossoms, later, by cutting out thousands of newlyset fruit, and latest, by covering the ground beneath with rejected apples, cherries, peaches, and pears. No tree can mature all its blossoms. As a last stroke, the wind winds up the tree in a crash of ruin. If you want fruit of first quality and size, thin out to taste, which means that you fill more baskets with fewer peaches or prunes and get a larger price than were you to let all the fruit that forms struggle toward an unattainable maturity.

Some trees require but little pruning, as cherries and the plum family generally; others require much, as apples and peaches. Of grape-trimming I have already spoken. The safe rule for all fruitplants is to cut out dead and superfluous growth. But the difficulty is to determine what is superflu- 
ous. Orchard trimming begins at planting and continues during the life of the tree. During the first five years the shape of the tree is fixed. Avoid the two-limbed or Y-shaped trunk, which is a constant invitation for the wind to split. Three or four limbs in balance give the true form. If you cannot avoid the two-limbed trunk, and wind or snow or ice or heavy crop split the tree, you may perhaps save your tree, even for years of service, by bolting the split limbs together and holding the limbs above the split by a few wire strings, carefully protecting the bark against the wire by means of pieces of wood. By twisting the wire like a tourniquet you may ease the strain on the bolt. The tree may grow together and serve you many years; but you will have to watch the wire, insert new blocks of wood, and favor the tree by rather heavier trimming than usual. A hoop, or chain, or wire should never be allowed to come directly against the bark; it will girdle the limb. The crevice in the split may well be filled with grafting wax or tar or paint to keep out water. If the tree is one in a large orchard and is young, prudence will root it out and set another in its place. The supreme rule of the orchard is to have only strong, healthy bearing trees. Weaklings take all the labor and amount to nothing. It is best to supplant all old trees, which are past their prime, by new ones. The added profit of the new tree will compensate for the loss of the old one. Remember that it is the best trees which pay all the expenses of the 
inferior ones. Therefore have as few poor ones as possible. Strawberries are best trimmed by setting a new bed every year. Raspberries, dewberries, and blackberries must be trimmed annually by cutting out the old canes. Currants require some trimming, but chiefly of dead wood, broken canes, and superfluous sprouts. Gooseberries must be trimmed to keep them within bounds.

Of tree fruit the peach ever tends to overgrowth of foliage and therefore bears vigorous trimming; no other tree so much. "Heading back" is the rule with peaches. Such trimming prolongs the life of the tree and prevents its reaching an unmanageable height. Trimming the tree low prevents wind-break and all its evils. But greatest care must be taken to make clean cuts, close to the body of limb or trunk, and, if possible, to paint all large wounds. The tree, if healthy, soon grows a cover of bark over small cuts. When the tree has been lacerated by wind-breakage, the bruise should be cut down smooth and painted over against rot and disease. Sweet cherry trees are brittle, are subject to the borer and to rot. High winds play havoc with them, and ice storms are their great enemy. It is always perilous to risk much weight on the limb of the tree. I do not speak here of tree-diseases but of trimming. One can soon discover which of his trees grow slowly, which rapidly. The rapid growers require heaviest pruning. Fruit of quality means abundant sunlight; therefore the rule is for open centers. Earth 
and sun will do the rest. An open center does not mean a cave, or a shell-like top. It means ventilation and sunlight: no more. Pruning and trimming may be perennial. Carry your pruning-knife in your pocket and trim at any time; tar and paintpot are not needed when you use the knife.

Grapevines must be tied as well as trimmed. They must hang in the air, not lie on the ground. Grape-trimming, in the Lake Shore Valley, is the winter job. It may begin as soon as the grapes are picked and the leaves have fallen; it must be finished before the sap starts in the spring. But every wind brings down the vines and calls out men and women with their bunches of string, cut in length, to tie up the vines again to the wires. When the vineyard is trimmed and the canesthree or four in number-are fastened to the wires, short lengths of a fine wire are used. No small part of the expense of running a vineyard is caused by the trimming and tying of the vines, particularly the tying after a high wind. When the vines are trimmed and tied and the brush has been hauled out from the rows and burned, the vineyard is ready for cultivation. This begins as soon as you can work the land; whence the desirability of having "early land"-that is, light gravel, or loam, as against a stiff, heavy clay. 'Yet the heavy clay land, though it cannot be worked early, produces grapes fine in quality and abundantly. But it is hard ground to work and therefore the more expensive. In the Lake Shore Valley 
it is cheaper in price and lies along and near the summit of the hills. It is higher above the sea level than the gravel and loam lands of the Valley; higher by from one hundred to a thousand feet. ${ }^{x}$

The manner of cultivating a vineyard is not a matter of common agreement among fruit-growers. They are unanimous that the vineyard should be cultivated,--but of details let no man speak, expecting every man's approval. Following the principles of plant-growth, it is evident that the time in which to cultivate a vineyard is while the vines are growing. We cultivate both for vine and for fruit. When vineyards were first planted in the Valley, from I855 to 1860 , and for some thirty years later, fruit-growers thought only of the fruit, taking the growth of vine for granted; but since 1890 , the vine food, so to speak, in the soil has decreased and the vines have been stimulated

The mean level of Lake Erie is $\mathbf{5 7 2 . 8}$ feet above mean sea level. The land of the Lake Erie Valley rises rapidly from the lake level; indeed the beach is narrow, - rarely more than three rods, and most of the shore is a series of bluffs, quite steep, overhanging the beach from fifty to two hundred feet. From the top of the bluff the land rises in successive waves which form the floor of the Valley. This is from two to two and one half miles wide to the foot of the hills, at the south. The hillside is a gradual rise, attaining to the crest, or fruit-limit, at the south, a height of from seven hundred and fifty to thirteen hundred feet. There are fields of gravel and of clay both in the Valley proper and on the hillsides. The gravel and loam is common south of the fruit-limit. This limit coincides precisely with the area ventilated by the lake winds. Practically all land from which the lake is visible is fruit-land. The frost line mentioned in the third chapter marks accurately the line along which the lake may be seen. In later years fruit-culture has been pushed well up to this line and somewhat disastrously to the south of it. 
to bear fruit, often at the expense of the vine and to the serious injury of the vineyard. We hear, therefore, nowadays of "the growth of wood" as little or great, and men are learning "no vine, no wine."

First, last, and all the time the fruit-grower needs a strong, healthy vine. Stable manure in quantity is needed, or its equivalent. This means, with the disappearance of cattle and hogs and stock from our fruit valleys, that resort must henceforth be had to cover-crops plowed in,the clovers, vetches, beans, and turnips. If you can begin the cultivation of your vineyard by plowing in a heavy cover of barnyard manure, or a heavy growth of some cover-crop, you are taking no uncertain step towards profit. Which clover you shall use,-crimson, mammoth, or Alsach, or whatsoever this crop may be, you sowed it the season before, directly you had completed your year's cultivation of the vineyard. This means not later than the opening days of August, or even two weeks earlier,-as the season may permit. It is a stiff job plowing a vigorous growth of clover, in bloom, and the more complete the growth the more valuable as fertilizer. The requisite is perfect turning of the sod so as to make a clean job. Then follow in succession, the season through, disc-plowing, horse-hoeing, hand-hoeing, cultivating with the two-horse cultivator,- the number of times all this is done depending upon the capacity of the fruit-grower to raise grapes. 


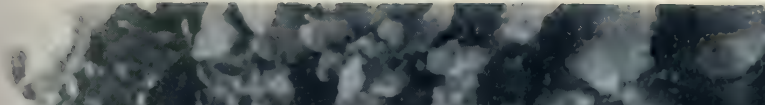

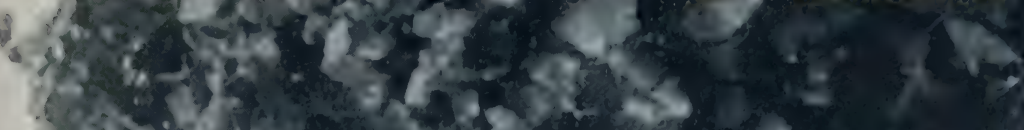

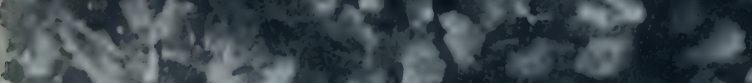

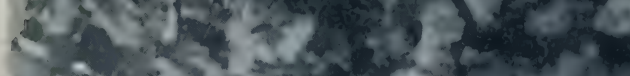
it $x^{2}=0.16=$

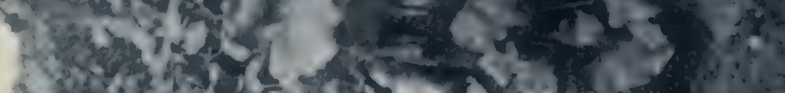

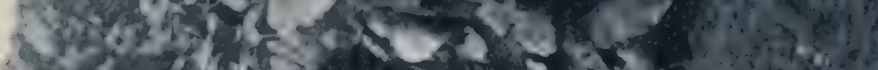

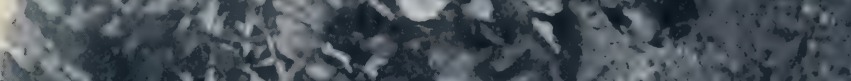

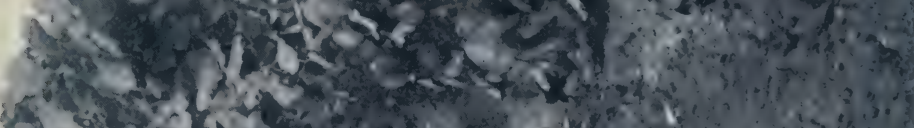

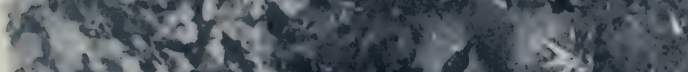
$1+76501 \%$ in $x^{2}=x^{-1}$

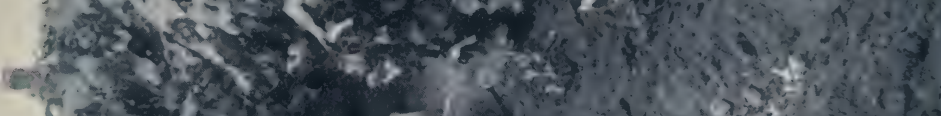

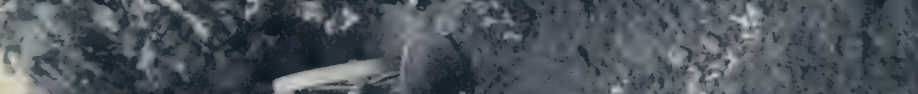
$5 x^{2}, 2.250$

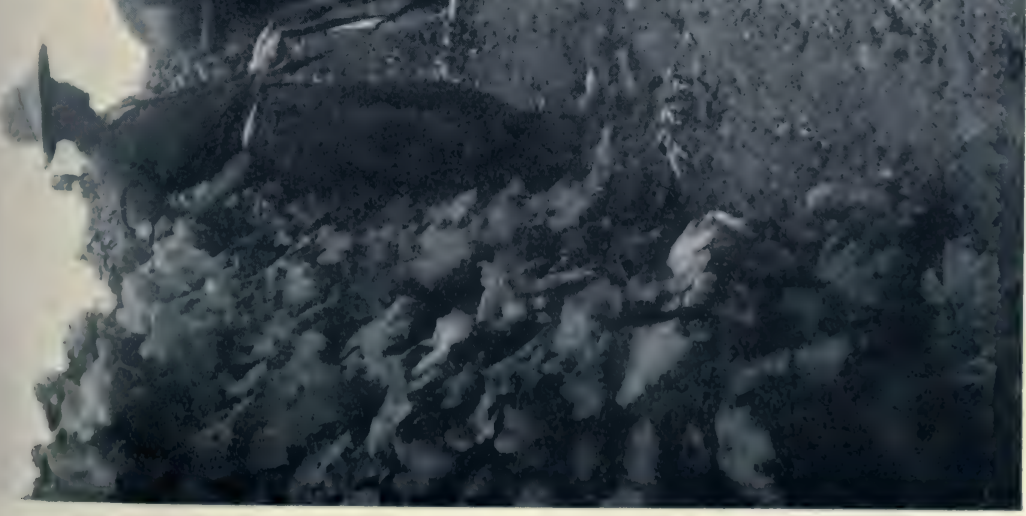

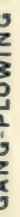



What is needed is thorough stirring (drainage) of the ground. If your land is like an ash heap and is full of humus, you have done your work right. You keep down the weeds in order to stir and drain the soil. You stir the soil so as to keep its food supply in circulation. Grapes root both wide and deep; they tap the soil at top and bottom. They endure moderate heat $\left(75^{\circ}-90^{\circ}\right)$ and protracted drouth, provided your soil is like an ash-heap and filled with humus. The color and size of leaf and the length of vine of the summer's growth test the health of your vineyard. The grape blossoms in mid-June, in the Lake Shore Valley; in mid-July the growth of vine is sweeping the ground between the rows and the leaf is of full size. In mid-August the grapes are two-thirds full size and the leaves are shading into brown and curling at the edge. In mid-September the brown has darkened, the leaves are becoming brittle, the fruit is of a tint of red. In mid-October the leaf has ceased its functions and here and there lies dead beneath the rows; the fruit is purple and odorous. The pickers are in the field and the harvest is on. If your vineyard turns brown in July, or early August, you may know that your land lacks humus and nitrogen; that your vines have not enough to eat. You will discover that the feeble vines have stunted and scraggly bunches. "Feed your vine and make your wine," is the old German proverb.

If you have made your soil aright, you have fed the vineyard both for vine and fruit. You have 
kept your team and men at work till late July, ever cultivating the soil. Then, when the ground is like an ash-heap and cultivation is over, you sow (or drill) your cover-crop, to be plowed in for nitrogen next year. If you are fortunate and get in your clover seed just before a rain, it will germinate in three days, under an August sky. By the time snow flies, your clover will quite cover the ground and stand nine inches high. Whatever nitrogenous cover-crop is used, its value depends upon the growth it has made when plow-time comes in the spring. This means as early as possible sowing the previous season and this cannot be earlier than the last cultivation of the vineyard. It is not the clover top but the clover root that stores up the desired nitrogen in the soil for available use. Really the cover-crop is under ground, though we commonly measure its value by leaf, stem, and blossom. In order to get an early sowing of this cover-crop, the fruit-grower must have begun his spring plowing as soon as the weather permitted. Early begin, early win. It is the late summer and the fall growth of the clover that gives it worth ; or, if let grow and blossom in spring, all haste must be made in order to get in the cultivation necessary during May, June, and July. August cultivation is largely merely marking time. While we do not raise fruit in order to raise a cover-crop of clover, vetch, or turnips, these must be raised and must sufficiently mature to be of use, or we must apply barnyard manure. 
There is no other way of securing humus in the soil.

It is therefore on schedule time that the cultivation of the vineyard must be done. Delays here are not merely dangerous, - they are fatal. As you ride through the Lake Shore Valley inspecting fruit-farms in July - the best time to judge their condition-you will discover that orchards and vineyards-indeed all crops, in soil like an ashheap and filled with humus-deep, moist soilare always of a dark green color; the growth of wood is abundant as their canes, well-fruited, will attest. The presence of weeds does not always show neglect of the orchard or vineyard. It is the hard, baked soil, the old stubborn sod, the wire and quackgrass, the goldenrod and the milkweed, the sourdock and the sorrel at which you take warning. If the ground beneath the grape-row is green with chickweed you may know that the soil is rich and mellow. Chickweed is potash growing and has no superior as a friend to the fruit-grower. It never is seen on poor soil. Were I asked to name the simplest, surest test of a well-fed soil, I would ask, Does it grow chickweed? July is rather early for this little friend, but if you have cultivated your vineyard aright, it comes of itself. In September the soil seems surcharged with its tiny seeds (Who ever saw one?) eager to germinate, to cover your land with a thick, green cover, which will be a winter blanket protecting your plantation. And there are other weeds which are good signs, - as 
pigweed and burdock which mean rich, moist soil. But the daisy, the gypsumweed, mean hard, lean land, neglected, and the brown grass on untilled land means soil-starvation. Nature abhors naked earth, and hastens to cover it over with a blanket of green; grass if she can, weeds if she must. I believe in a well-covered soil in winter; a well-cultivated soil in spring and summer; a food-filled soil in autumn. Left to herself, Nature grows grass and weeds on our plantation. Then come November winds and December snows, and freezing and thawing of the earth in January and February, and the weariness of March and its desolation. If the earth is well covered by a matting of straw, dead grasses, weeds, even a blanket of snow, - shrub, tree, or vine will suffer no harm. Raw, uncovered land in winter is leached by storm, by rain, snow, and ice, and so loses its virtues. The snow is our friend if we can get it to lie still, even to the depth of a foot on the ground. But if it blows hither and yon and the land is swept by the besom of the storm, now covered with snow, now bare-blown, the surface freezing and bleaching, vast injury is done. The surface drainage of the soil is quite destroyed and alternate freezing and thawing of the earth means death to many a tree and vine. In some vineyards, planted in stiff, strong clay, the vines will be quite thrown out of ground, so that the first horse-hoeing quite completes the ruin, if the tool is held by a careless hand. It is usual, all over the Valley, to horse- 


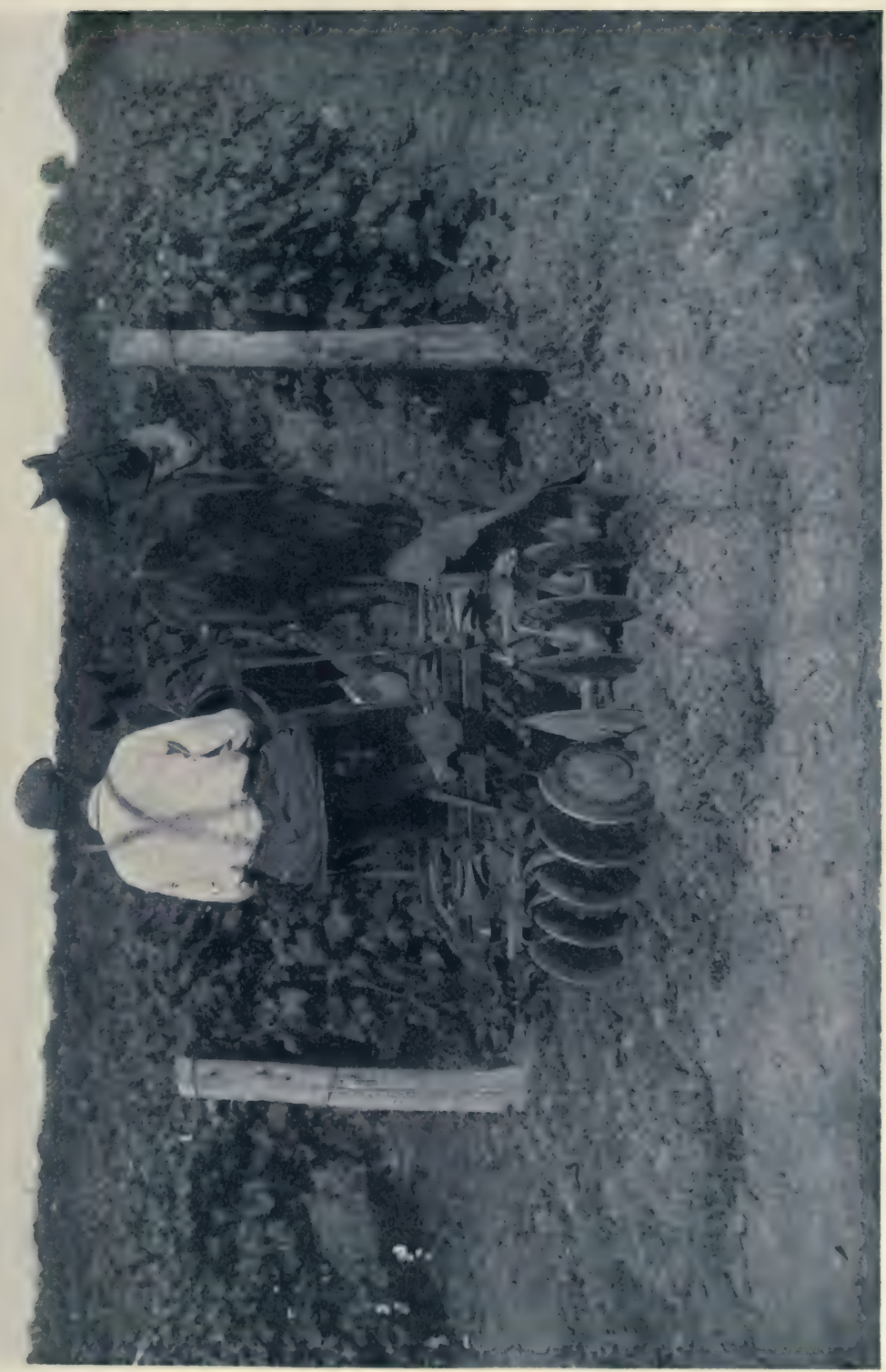

$\frac{2}{3}$ 

hoe a last time just before sowing the cover-crop. This raises a ridge of earth against the vines to a height of eight or even ten inches and protects them against too severe extremes of wintry weather.

The stock of tree or vine is small part of its feeding organs. These are the rootlets, deep in the soil, or spread a few inches beneath the surface. It is these surface roots, within the reach of the frost, which we protect summer and winter. If the snow overlays them to a depth of a foot or more, and remains all winter long, the soil never bared to the frost, it will keep an even temperature, and if the snow is deep enough the ground will not freeze. A permanent snow cover is one of Nature's means of protecting the soil. Weeds, grass, and cover-crops generally catch and hold the snow and keep it quiet the winter long. The scantier the snowfall the greater the need of the cover-crop. Thus the clover and the vetch serve as faithfully in winter as in spring when they are plowed in to feed the plant. It is like an overcoat in winter and a loaf of bread the rest of the year. I attach greatest importance to blanketing the soil in winter with snow and a matting of straw, clover, vetch, grass, weeds, and especially chickweed. Nearly every fruit-farm has some hillock or slope that is swept by the winds and washed by the rains. It washes rather than drains. The snows never cover it in winter and it is difficult to get a "catch" of any cover-crop in summer. It is the hard, barren, unprofitable spot on the farm. The only thing to 
be done with it is to cover heavily with stable manure to secure humus, and to apply the commercial fertilizers more generously than elsewhere on the farm. It is the most expensive spot on the plantation. If such spots are many, you better own some other land, for this spot is expensive to work, difficult to keep in health, unfriendly to tree or vine, and productive, if at all, of fruit small in quantity and poor in quality. Some fruitgrowers choose such hillocks for orchard sites, under the unreasonable tradition that trees like hillsides and hilltops. Doubtless you can raise trees-rather poor trees,-but you will have difficulty in raising fruit on such spots. Some fruit-growers, knowing no better, and owning many such barren cones, think they are raising fruit. As a man thinks so is he, and, it may be added, so he believes his fruit to be. In selecting land for a fruit-farm, one must remember the true value of hillocks. A hillside is different, for an entire fruit region may be a hillside.

I have reached the conclusion that in fruitgrowing all cultivation should obey the advice of the old Greeks. "Much but not too much." But a Greek maxim, like Greek morals, must be taken in a Greek sense. Much but not too much is another way of saying "Enough." The test of the whole matter is simple: The tree is known by its fruit. In horticulture luxurious growth of wood-stock and abundant fruit mark "Enough." Any tree, vine, or shrub on a neglected fruit-farm 
will produce one apple, one plum, one bunch of grapes fit for the county fair, but does it produce fruit all of which you would enter for a premium? First prizes have been given for fruit culled from a neglected tree, and were the tree before the judges they would not award the prize. Some fruitgrowers use packages with two faces: the upper, or top, for big bunches of grapes of fine quality; the lower, or bottom, for odds and ends, culls, even stones, leaves, and weeds. This means that cultivation is on the surface, - at least of the basket. But the fruit-farm is more truly mirrored in the bottom of the basket. It is easier to cultivate the fruit-farm to quality and quantity than to cultivate the fruit-grower. There is that about horse-trading that affects the morals of the man and the appearance of the horse. Even a deacon deteriorates in the process. There is that also about fruit-growing which affects the fruit-grower; he may run to culls like his trees and vines. Indeed, it is somewhat of a strain on some men to be fruit-growers. Yet, happily, there are growers and growers. All do not neglect cultivation of their plantation; all do not raise a preponderance of culls, or top off the scraggly fruit with a thin layer of "selected fruit," as the label on the basket bravely, not to say effusively, informs the purchaser. It is a case of human nature; the fruit of the garden is no better than the gardener. You can read the character of the fruit-grower in the condition of his fruit-farm. 
There is difference of opinion as to the best cultivation of orchards: Shall they be kept in grass? Plowed, dragged, cultivated, sown to cover-crops, and treated like the vineyard? This means: Can the tree feed, grow, bear fruit of as good quality and of the same quantity in sod as in cultivated ground? My own experience favors cultivation. Feed the cherry tree and it will feed you. Now any tree can feed in sod ground, but can it get enough food to produce what we want it to produce? A tree in sod is not unlike one in the wild. By stirring the surface of the land you drain it, ventilate it, open up the pores, and accelerate the circulation of soluble plant-foods in the soil. Moreover, you by cultivation destroy innumerable enemies of the tree, as grubs, worms, even toxics in the soil which otherwise would feed on the tree to its injury. A hayfield is apparently a clean place, but a hayfield is a hayfield, not an orchard. Much of the virtue of fertilizers scattered over a hayfield vanishes, in air, into thin air. Plow your hayfield and the fertilizers get into the laboratory of the soil and are transformed into plant-food. A tree in a meadow gets "root-bound." Yet, let us not forget, we have set a standard, an artificial standard, for the fruit-tree. Not merely apples, pears, cherries, plums, but finest apples, pears, plums, and cherries, all pulp, and, if possible, seedless or, at least, seeds little. Nature has her eyes on the apple seed; we have ours on the apple pulp. An apple tree in sod will grow apples; one in culti- 


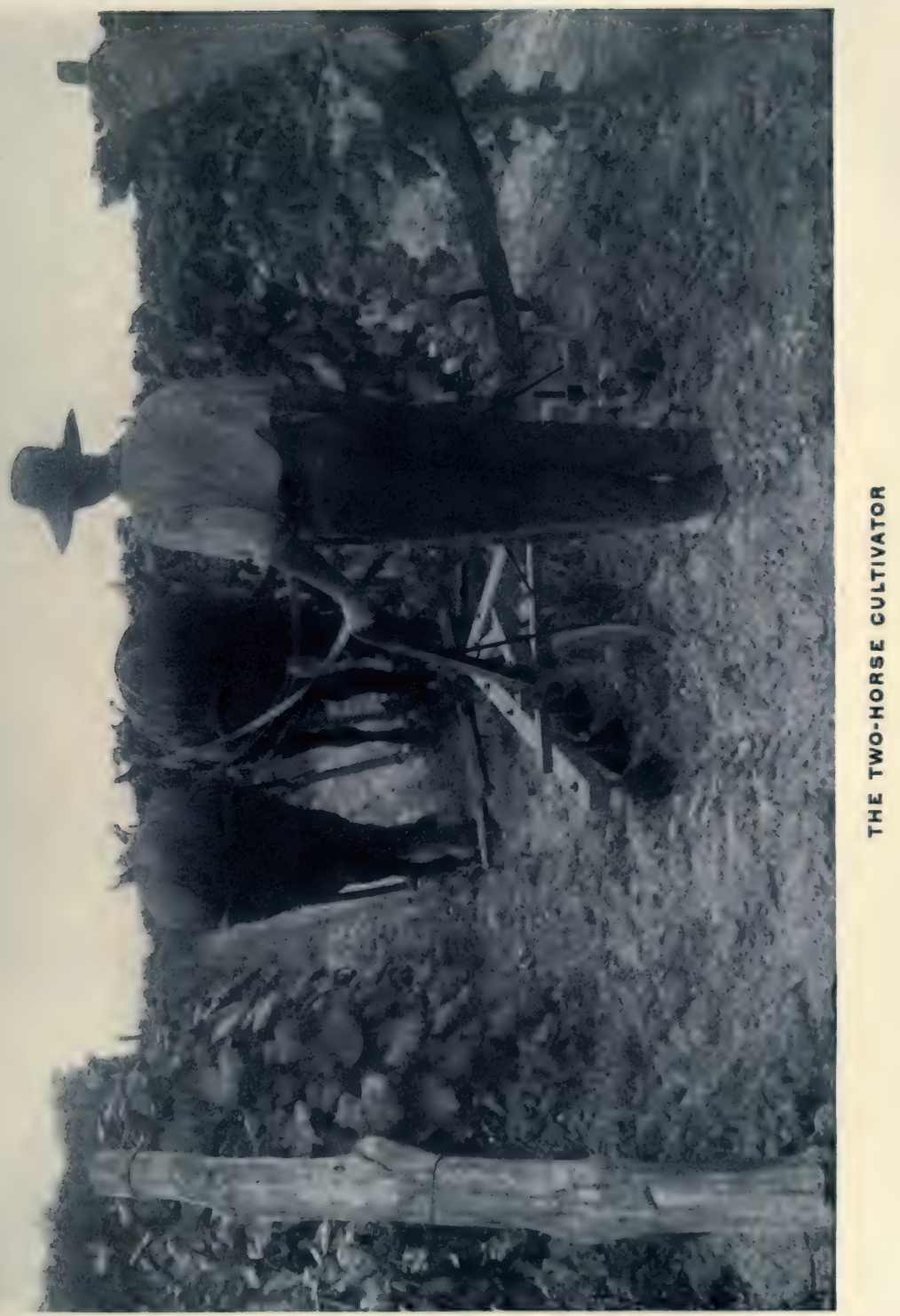



vated soil will grow finer apples, by our standards. The cherry tree in sod tends to black bark and decaying limbs; the tree in cultivated soil tends to reddish bark, and tough, vigorous limbs. Each will fruit, but the larger, finer fruit will be found on the cultivated land.

Orchard soil is made like vineyard soil or garden soil. Cover-crops, or stable manure, for nitrogen; potash for fruit: phosphoric acid for both; a soil as loose as ashes, and full of humus; these in your soil your orchard will grow healthy stock and fine, abundant fruit. And in winter, it is well if in your orchard the snow lies deep, and beneath the snow a thick matting of clover, vetch, grass, or chickweed. The time for cultivating the orchard is during the period of vigorous yearly growth, from opening spring when, as we say, the sap starts, till the fruit is ready to pick. Winter trimming, spring and early summer cultivation, winter covering,and the cycle is completed. This is the orchard calendar. The more vigorous the growth of the tree, as the peach, the more cultivation and feeding are required. Not that any fruit-tree can live without food and care, but peach trees are rapid growers and heavy feeders, especially in their youth,-and wise management will keep them young. In the Lake Shore Valley they are always rapid growers and heavy feeders; in less degree are cherries, prunes, and apples, in the order named. Many fruit-growers plant the young orchard and then treat it like trees in the wild,- -now and 
then, however, cutting out the underbrush, briers, and weeds. You can recognize these orchards (?) as you drive about the Valley. Perhaps such cultivated wilds may be found in other fruit sections of America, for it is not to be supposed that all the funny fruit-growers are concentrated in one Valley. It is true, though paradoxical, that these are the highest-priced orchards, just as neglected vineyards are always the highest-priced vineyards in the Valley.

The more neglected the plantation, the higher is its true cost. The cheapest plantation is always the best one. In the cultivation of fruit, trees, shrub, and vine must be protected from enemies, as well as be trimmed and fed. These enemies are insects and fungi. Nature, the law of things and men, in a measure, looks out for her own and sees to it that every insect and fungus too shall have its enemy, fungus and insect feeding on insect and fungus. This is Nature's fine balancing which makes possible the perpetuation of each tree after its kind. For this end Nature does not find it necessary to exterminate every enemy of plant life, or animal life would vanish, including man himself. If the plant manages to reproduce itself by the maturity of a few seeds, and by their germination and continued growth, the cycle of life is made complete. We as nature-mongers, as fruit-growers, are more exacting. We demand fruit of the kind that suits us and far more abundantly than does Nature, therefore insects and fungi are 
greater perils to our orchard than to Nature's wild trees. It is not enough for us that the apple or cherry tree merely fruits; it must fruit abundantly and of the quality we desire. Then, too, in concentrating the energy of the vine or tree upon some particular part, as pulp in cherry or prune, and liquid in grape, we disturb the balance of the plant's life and so weaken the plant against its enemies. The cherry tree which bears our best fruit, in the stern economy of Nature is a weakling, unable to withstand disease, and this cherished fruit invites insects and fungi in myriads.

What must we do?

We may so feed the tree that it grows and bears fruit in such quantity that, despite the ravages of insects and fungi, we have an abundance of perfect fruit left and the tree also survives. Or, we may destroy the enemy and save the fruit, also relieving the tree of its enemies. Our supreme purpose is to keep the tree healthy and to raise an abundance of perfect fruit of finest quality. A tree may be withered by fungus or eaten of insects and for a time seem healthy and able to resist the attacks, but at last it succumbs. To save it we poison the enemy without killing the tree or injuring the fruit. This is the purpose and the art of spraying.

Now spraying is a preventive and a remedy, not a fertilizer; it is medicine for the sick, not food for the well. Like all medicine it disturbs the system. Usually medicine to the fruit-grower is no more than a stimulus to some organ or tissue of the 
body. Spray for the fruit-tree is a mixture which smothers, drowns, heats, chills, or, when taken as food by the insect or the fungus, poisons the enemy yet does not injure (at least seriously) the plant that is sprayed.

The enemies of the fruit-farm attack root, bark, stock, leaf, bud, flower, and fruit,- that is, the whole plant, but rarely every part at one time. The rootworm strips the grape-root of bark in a spiral from end to end, beginning seemingly at the tip. For a few days it lies inert in transition from worm into larva when (about mid-June) it emerges as a beetle, deposits its eggs close to the ground beneath the loose bark of the vine-stock, climbs or flies to the leaf and begins its zigzag course of eating its way through life, marking the leaf as it moves. It flies from leaf to leaf and for a time enjoys quite a sociable life with its kind. It is very prolific. The deposit of eggs is not made directly it leaves the ground but at some time after it has flown about. It cuts the leaves into shreds. The leaf hopper sucks the leaf from the under side, leaving the whole vineyard as brown and sere as if a fire had passed through it. Fungi, or mildew, black rot, brown rot, grow on the fruit and absorb its juices. The rosebug eats the buds of the grape blossom, leaving the vineyard fruitless. The curculio lays its egg in the blossom of the apple, the cherry, the peach, the pear, the plum, and the worm feeds on the young fruit, poisoning, defacing, shrivelling it to a hard, skinny cover stretched over 
pit or seeds. The moth lays innumerable eggs which, hatching on leaf or bark, feed in armies, strip the orchard of its foliage, choke the trees and preclude all hope of fruit. The borer pierces the bark and kills stock and limb; the scale shingles over the bark with its wretched shields, sucking up the sap, and leaving the tree as dead as if scorched by fire. So every plant known to the fruit-farm has its enemies. Not a tree or shrub, not a vine or root, not a tuber or leaf of any sort escapes,-no, not one.

The fruit-grower is confronted by legions of enemies ready to swoop down upon his plantation and consume it from the face of the earth. As the country becomes more thickly settled, as forests are destroyed, prairies broken up, the vast wild made a habitation for man, insects and fungi, deprived of their feeding ground in the wild, have turned to our feeding ground, the cultivated field, to our wheat, our cotton, our orchards, our vineyards, our gardens. It would be presumptuous to attempt to catalogue these enemies. The Bulletins from the Experimental Station, State and National, and the innumerable books by experts trace the life history of these pests and tell how to combat them. It is an appalling task but it cannot be escaped. ${ }^{x}$

"As an example of timely and practical contributions, see "Fall Manual of Practice in Economic Zoölogy," Ohio Agricultural Experiment Station, Wooster, Ohio, U. S. A., November, I9II, Bulletin 233, 164 pp.; Index, vii. pp. Illustrated. This tells the fruit-grower the name, habits, ravages, and methods of destroying every insect, worm, grub, moth, 
Regions free from pernicious insects and fungi yesterday are infected to-day; those free to-day will be infected to-morrow. As the price of liberty is eternal vigilance, so the price of fruit is ceaseless spraying. It must from henceforth be counted an essential part of fruit-growing.

Now fruit-growing is not only special farming but itself breaks up in specialties. One must know his orchard and his vineyard. In spraying the rule is, Each tree after its kind. For this reason alone the fruit-grower should beware of many varieties as of grapes, and many kinds of fruit, in petty sections, this of plums, that of peaches, a third of

beetle, bug, borer,-whatsoever its character,-that injures the fruitfarm. Of similar value are "Important Insecticides: Directions for their Preparation and Use," Farmers' Bulletin No. 127, United States Department of Agriculture, by C. L. Marlatt, M.S., Washington, Government Printing Office, I90r; and "Insecticides and Fungicides: Chemical Composition and Effectiveness of Certain Preparations," Farmers' Bulletin, No. 146. By J. K. Haywood, Washington, Government Printing Office, I902. These may be had for the asking.

The Ohio Agricultural Experiment Station issues a "Spray Calendar," for the treatment of diseased conditions in plants, - a Bulletin for plant diseases and insect pests, prepared by W. J. Green, A. D. Selby, and P. J. Parrott. This sheet is of extraordinary practical value. It gives specific formulas for all fungicides, telling exactly how to prepare them and apply them; specifically states the seed or plant that is attacked by insect or fungus; for what it is treated; how to be treated; and an elaborate spray calendar for each plant, shrub, tree, vine, stating the exact time of successive applications of spray and how much to be used. There are also "remarks and cautions" for the benefit of the inexperienced.

The fruit-grower will wisely correspond with, or at least secure these and like valuable publications from, whatsoever Experimental Stations are within his reach. Both the General Government and the State Governments now expend vast sums for the benefit of farmers whatever special branch of farming be pursued. 


\section{The Cultivation of the Fruit-Farm $\quad$ I55}

apples, another of cherries. Sixty acres of Montmorenci cherries are far more valuable than sixty acres subdivided into small plantings of apples, currants, gooseberries, plums, peaches, and so on through the list. The care of an orchard of one kind of fruit differs from that of another kind. If all is of one kind, or if the fruit-farm is given over to subdivisions of respectable size, in different fruits, the administration is more economical and profitable than many trees, plants, shrubs, vines of many kinds. The would-be fruit-grower is attracted by names, sounds, and memories of fruit he has seen in market or at fairs. Let him concentrate; let him specialize. Avoid bewildering varieties. They are wholly unprofitable and multiply the evils of farming. If he has secured land within the proper climatic belt he may securely specialize in fruitraising.

The Lake Shore Valley is adapted to grapes, cherries, peaches, prunes, plums, apples, berries of all kinds, currants, melons, and some add English walnuts; yet it is not a profitable apple country because of the winds which sweep down from Lake Superior, two thousand miles away, across the continent, and play havoc with the apples. There are apple sections in America where destructive winds do not break through and tumble the fruit prematurely to the ground. Yet there are profitable apple orchards in the Valley. One must assume a wind-risk there if he attempts to raise apples. It is not a pear country, though thousands 
of bushels of pears are raised. The trees grow luxuriantly, blossom freely, and set abundantly for fruit; suddenly the blight burns the foliage to a crisp. The scale too affects the pear. When the blight can be prevented,- - the scale can now be successfully treated by spraying,-the Valley will become one of the most profitable pear sections in the country. The fruit-grower must move along the line of least resistance; hence he must raise fruit best in quality, greatest in quantity, and with least possible labor. This means that he must utilize the privileges of climate by utilizing all means and methods of fruit-raising known to experience. I believe that the Valley,-or any other fruit section,- - can be made to be the profitable home of all fruit possible to its climate. The problem is for the fruit-grower himself to solve.

Of enemies of the plum and the prune the name is legion and the list lengthening every year. Black knot, scale, curculio, brown rot (fungus), and other enemies swarm down upon trees of this family. Bordeaux mixture holds the fungi in check; shaking the tree brings down the curculio; the scale must be killed by spraying; moths and insects generally can be routed also with the sprayer. It is not a difficult task. Pruning of the tree seems to increase its power to resist disease. But too many plum trees of mixed varieties are like an overcrowded hospital. No one in the Valley need fear to attempt a plum or prune orchard because of its insect or fungi enemies; the spray 
bulletins and calendar and the active, resolute, sensible man will speedily rout them.

Peaches like plums invite enemies, and of a different sort,- -yellows, curl-leaf, root-gall, and of course the borer, the fungi that cause rot of tree and fruit and some obscure diseases of which as yet we know practically nothing. Despite these discouragements, peaches are raised with profit in the Valley. But as yet spraying peach trees is somewhat uncommon there. He who sprays has fine peaches and many. The freezing and thawing of the soil undoes the peach tree, but this fatality may easily be avoided by proper management of the soil,-winter protection by cover-crops, and vigorous feeding of the tree. Peach trees are beneficiaries or victims of climate, but oftener, are victims of the fruit-grower's neglect. Peach culture is bound to confine itself to what may be called the natural peach regions of the country, of which the Valley is one.

Sour cherries are less liable than sweet cherries to disease and to insect and fungi pests. Mildew, brown rot, the curculio, the slug, the borer, partly exhaust the list. These attack all cherry trees, sweet or sour. But remedies are known, are available and the fruit-grower need not fear to undertake cherry culture provided he is clearly within the climatic cherry-belt. Follow the borer with a wire; Paris green kills the slugs,- -and men also if carelessly handled; the Bordeaux mixture checks the ravages of most cherry enemies. The 
trees, notably the sour varieties, are not subject to scale. But the tree is a particular plant and will not fruit everywhere in the Valley, as along the crest of the hills near the frost line. Here it is only a shade-tree. The Valley is however a cherry section even though a small one.

The diseases of the grapevine yield to cultivation and spraying. The fungi, but not all insects, are killed by the Bordeaux mixture. The rootworm must be attacked with spray above and cultivation below. The arsenical preparation is effective, but the stirring of the ground as the rootworm emerges, or transforms itself into a beetle,-while yet in the larva state is his most certain destruction. A time comes in June when this change is made, when the larva is slowly working its way from earth to air,-a small, white, viscid, wriggling creature, shaping into a beetle. Sun, wind, or disturbance of the earth destroys it. Therefore cultivate thoroughly at this time. The birds will help,-if you have birds; possibly they have been exterminated by pot-hunters and idle boys. Perhaps you kill birds! If so, you deserve the rootworm! A patient file of educated hens greatly helps at this juncture. So spray for the beetle; horse-hoe, away from the vines, for the larvæ; you will have your reward. In the Valley, so persistent and thorough has been the campaign against the rootworm, it no longer gives the fruit-grower anxiety.

Of far greater peril is the thrip, or leaf hopper, a 
small white moth which sucks the life out of the leaf of the vine. Happily this destructive insect, which, unchecked, will transform a vineyard into a ruin of seemingly fire-swept rows, with withered grapes, is completely destroyed by the Bordeaux mixture with nicotine added in small quantity. Its ravages are no longer feared.

The composition of spraying material for various specific purposes and the machine that shall be used sooner or later compel the fruit-grower's attention. The preparation of the spray; the ingredients, the particular application, and the proper time of spraying are adequately set forth in the Bulletins to which I have already referred. The selection of a machine is a matter of some difficulty. The qualities desired in a machine are efficiency and cheapness, but as yet no machine is inexpensive, and all are not effective. The types on the market are run by horse-power engendered by the motion of the wheels of the sprayer, or by steam power, or gasoline power producing steam. Either coal or gasoline is preferable to horse-power and the steam-power machines work when the machine is stationary as it must be for the spraying of trees, or when the team is drawing the machine along the rows of trees or vines. The fluid must be ejected as finest mist or spray and must thoroughly drench the plant. While spraying is a labor, it is not, with the best type of power machine, a prohibitive labor. So far as I know there is not on the market a machine which is first-class in every particular- 
that is, thoroughly made, material strong, and whole equipment durable. Spraying machines are made to sell to farmers at a profit. Yet we cannot get along without them. They are certain to be improved, to be made more durable, more effective, and to sell at a price proportioned to their strength and efficiency. ${ }^{x}$

Considering fruit-culture in all its aspects, for the Valley, spraying resolves itself chiefly into a timely application of three kinds of spray:

The Bordeaux Mixture:

Copper sulphate (blue vitriol), 4 lbs.

Quicklime (not air slaked), 4 lbs.

Water to make 50 gallons;

or, if too strong, all the water and half the other ingredients. The mixture must be used fresh.

Arsenate of Lead:

Arsenate of soda, $4 \mathrm{oz}$.

Acetate of lead, 11 oz.

Water, 16 gallons.

This is sometimes called Disparene and may be had commercially.

Nicotine Solution for Leaf Hopper:

Water, roo gallons,

Nicotine, I pint.

This is an irritant, deadly poison and must be handled carefully.

Lime, Sulphur and Salt:

Stone lime, 15 to $30 \mathrm{lbs}$.

Flowers of sulphur, $15 \mathrm{lbs}$.

Water, 50 gallons.

Specific for scale.

The making of these mixtures requires an adequate equipment: an ample supply of water; facilities for heating any of the ingredients, and for complete intermixture of them. The Bulletins and "Spray Calendar" already cited, or similar authorities, should be consulted. The beginner may profitably examine some working spraying equipment before undertaking this part of fruit-farming. There are now some twenty-five specific preparations used in spraying; the three given above are the most widely used and may be called standard. In all mixtures 
That there has been a depletion of the soil under fruit-culture cannot be doubted. The wonder is that the land produces as heavily as it does. We have no exact record of the amount of soil-exhaustion, we only know that the growth of wood in the vineyards is not so great as it was twenty years ago, and that many vineyards have fallen off heavily in production. We know also that the Erie Valley is naturally a region for grapes. ${ }^{{ }^{x}}$ Only one conclusion can be drawn: that of soil depletion. This is true of all American fruit valleys. Complaint is made of destructive insects and fungi, of late years, - an enemy that proves weakening of stock. Two resources are available: feeding the soil, and its cultivation. Since the introduction of grape-culture in I855, the Valley has not known a failure of the grape crop. Few sections of the country have made such a record. In the Valley, during that time, other crops have failed. The steady service of the Concord grape is quite without parallel in horticulture. Vineyards fairly planted, not as wisely as we would now plant them, have for upwards of thirty years averaged a

the lime is added to prevent burning of foliage. In combination with the Bordeaux mixture Paris green may be used at the rate of one pound to $175-200$ gallons. The whole subject of combinations of chemicals and ingredients generally as fungicides and insecticides requires particular care and special Bulletins, or treatises should be consulted. Professor Bailey's Principles of Fruit-Growing, and The Spraying of Plants, by E. G. Lodeman, edited by Bailey, are invaluable to every fruit-grower.

'The grape crop, alone, of the Lake Erie Valley,-the Lake ErieChautauqua Grape Belt, for I914, sold for $\$ 2,607,415$. 
gross product of from eighty to one hundred and fifty dollars per acre. This income, year after year, may be set against the larger but less dependable income from berries and orchards of from two hundred and fifty to six hundred dollars per acre. These are extraordinary returns. But all land in the Valley is not adapted to berries, to orchard, or to currants. The climate encourages all the fruits I have mentioned; therefore the problem rests wholly with the fruit-grower whether they shall be raised. The making of the soil and the cultivation of the fruit are his problem. Cultivation includes drainage, spraying, trimming, and fertilization. But if all these be attended to and cultivation be omitted, there can be no crop.

The care of the fruit-plantation is both an art and an instinct. Instinct ranks first. Let no man attempt fruit-farming who does not like it. Let him not be tempted by reports of large financial returns. He will be disappointed. In fruit-growing Pope's famous line seems true:

"Man never is but always to be blest."

Let him who likes horticulture, and who has symptoms of moderate capacity for success, not hesitate to attempt it; some succeed; many fail, as in every other vocation. Experience alone breeds the fruit-farmer. If you trim cherry trees as peach trees, you will not raise cherries. If you get your spray solution too strong, you will burn your foliage. All sprays are water and something, and the " some- 
thing" is a poison-poisonous to the plant that receives, to the grower who grows, and to the eater who eats, unless properly applied. While we must handle poisons as it were with gloves, we must always mix them with common sense. Here we cannot safely go by rule of thumb, but by scale, weight, and measure. Never entrust the preparation of the spray to an inexperienced hand and trust to luck. The fruit-grower himself is the responsible man and must know how to prepare the spray, how to apply it, and what results to expect. He must of course be able to decide what sort of spray is particularly needed. So too must he be present, at least constructively, when orchards and vineyards are planted, trimmed, and cultivated. There must be no work of any kind on the place that he does not understand how to do, and preferably can himself do if necessary. That valiant heathen, Cato the Censor, wrote more than two thousand years ago the first principle of sound farming:

\section{"The face of the master is good for the land."}

In fruit-farming, "The hireling flees because he is a hireling." There may be exceptions, but they are always on some other fruit-farm than yours or mine.

While "book-farming" is still held in contempt by most farmers, it has in late years come into respectability by sheer evidence of value. We do not condemn medical schools, law schools, schools 


\section{I64 An American Fruit-Farm}

of engineering, nor do we longer condemn agricultural schools or experimental stations. Even some seeds sent out by Congressmen actually grow. We are discovering that the plain, everyday, bread-winning farmer cannot afford to make horticultural experiments, even were he so inclined. The State must experiment for the general welfare. This it does at the Agricultural Station. The results are printed and distributed free to all. This is not mere "book-farming" but scientific farming; it is based upon experience. But other people's experience in horticulture, whether told by lip or by the printed page, counts for little with most fruit-growers. $\mathrm{He}$ is successful, if at all, after many clostly blunders, most of which he might have avoided. The serious aspect of a blunder in fruit-farming is the difficulty of correcting it to the advantage of the corrector. It takes many years to get a fruit-farm in perfection,-if that stage can ever be reached. Few can afford to lose fifteen or twenty years by a blunder in setting out the wrong varieties, or planting a section to the wrong fruit. The supreme knowledge for the fruit-grower is how to raise fruit. This means knowledge of climate, of soil-making, of soil-feeding, of setting out the fruit-farm, and of caring for it when set out.

The fruit-grower is constantly confronted by difficulties, even by obstacles in the form of problems of soil-making, of selection of varieties, of cultivation, trimming, spraying, new enemies in 
insects and fungi, new tools, market risks, transportation, and the like. The list is of indefinite length. No agricultural station runs his fruitfarm, he cannot always obtain specific answers to his inquiries; he must rely upon himself. To many of his questions no satisfactory answer can as yet be given. They have not been worked out.

That we are reaching a higher plane of fruitraising is indicated by the increased efficiency of every department of horticultural effort; we are becoming scientific by grinding necessity. Legislatures make increasingly large appropriations for the investigation and treatment of every agricultural question, and, as never before in human history, farming in every branch is becoming an exact science. The agricultural schools do as much for the farmer as the law schools for the lawyer, the medical schools for the doctor, and the engineering schools for the engineer. Yet these agricultural schools are not and cannot be the equivalent of experience on the fruit-farm. The man who runs a fruit-farm wholly according to bulletins of Agricultural Stations, will cultivate, as Pliny said centuries ago, "in the very highest style" but "in mere extravagance," or, as Cato puts it, he will have a farm "with the spending habit" and "not much will be left over." In brief there are two ways to run a fruit-farm: keep a bank account in order to run a fruit-farm, or a fruit-farm in order to have a bank account. No farm is faultless; no orchard, vineyard, or section given to whatever 
plant, but some poor plants are there. The accumulated experience of the neighborhood, of other sections of country, and notably your own experience - usually very expensive - taken together with the wisdom of bulletins and reports from Agricultural Stations, contribute toward a closer realization of the perfect fruit-farm.

This all means that the fruit-grower to-day has access to aids and facilities in his vocation hitherto unknown. Fruit-raising is a science, a branch of chemistry, just as chemistry itself is an aspect of Nature,- - peep into her operations which we dub with a technical word. Countless millions of dollars are now capitalized in fruit-farms and related interests. We try to do precisely what Hesiod and Varro and Cato of old, and all horticulturists and farmers since their day have tried to do, and we do much as they did. There are no more bones in the human body than in the days of Asculapius or Galen; no more ingredients of fertile soil than when Cato was farming at Tusculum. The names of common diseases may be found in medical books four hundred years old. But while the names are identical, both surgery and medicine are more scientific now than then. Horticulture too has become scientific. We know very little about raising fruit as compared with the unknown, and we are working out knowledge all the time by experiment as well as by experience. For example: Cato advises to "manure pastures in early spring in the dark of the moon, when the west wind begins 
to blow." This strongly reminds us of advice we still hear about sowing beans in the new moon, till we learn that the shifting of the wind from out the west, on the Roman Campagna, and of course at Tusculum, marked with remarkable precision the shifting of the season. The wind makes, as it were, a "spray" or "fertilizer" calendar for the region. Cato dealt wholly with slaves, totally ignorant of letters, - creatures who, however capable as laborers, were guided by sight and sounds in Nature. A slave, were he the trusted overseer, would know "when the west wind begins to blow," just as by the color of the olive he would know when to pick the fruit for the oil-press. Our science of farming, worked out by retort and crucible and chemical test, agrees with the large conclusions of simple experience,-as "when the west wind blows" it is time to do a particular work. Nature herself is a great clock, and her hands point to the hours when things must be done opportunely. But Cato also prescribes for a sick ox: he should be given a raw hen's egg immediately; next day, a measure of wine from a wooden bowl in which the head of an onion has been scraped, and "both the ox and his attendant should do these things fasting and standing upright."

If a bone is dislocated [continues Cato] it can be made sound by this incantation: Take a green reed four or five feet long, cut it in the middle and let two men hold the pieces against your hips. Begin then to chant as follows: 


\section{In Alio. S. F Motas \\ Vaeta, \\ Daries Dardaries Astataries Disunapiter,}

and continue until the free ends of the reed are brought slowly together in front of you. Meanwhile, wave a knife above the reeds, and when they come together and one touches the other, seize them in your hand and cut them right and left. These pieces of reed bound upon a dislocated or fractured bone will cure it. But every day, repeat the incantation, or in place of it this one:

\section{Huat Hanat Huat \\ Ista Pista Sista \\ Domiabo Damnaustra.}

This you promptly say is nonsense and superstition, but turning to another bit of advice from Cato, you will discover that he tells you precisely how to plant and care for an olive orchard, how to make a bake-oven, how to raise figs, how to manage old vines, how to feed stock in winter, how to make, store, and when to sell olive oil, how to make bread and to cure hams, how to manage chickens and ducks, how to make wine, and to remove any unpleasant odor from it, how to select a farm, how to drain land, and what are the duties of the overseer. This all sounds modern. The matter is well put by Fairfax Harrison: "On questions of preventing malady, he had the wisdom of experience, but malady once arrived, he was a simple pagan."

What would we think of the fruit-farmer who, 
instead of keeping the team moving in cultivation of his land, spring and summer, should cut three green wythes, cross them over his little finger, take his stand at the corner of his vineyard and chant:

\section{Eeney, meeney, meiny, mo, Ikery, eikery, tinkery, toe, Concord, Cherry, Peaches grow!}

His wife (if he was so fortunate as to have one) would promptly send him to a lunatic asylum, and hire some sane man to run the farm.

We know as yet comparatively little about the mysteries of raising fruit,-soil-making, planting, plant-feeding, - and have much to learn about cultivation; therefore we turn eagerly to every service of agricultural school, experimental station, or actual experience however acquired. All associations of fruit-growers for exchange of ideas contribute to the general welfare,-local, county and State societies, which, as now conducted, bring together experts in every branch of horticulture, and thus extend the benefits of experience.

$\mathrm{He}$ who would raise fruit will soon learn by experience that fruit-growers, as a class, are men fixed in their traditions, jealous of association, and almost immovable in their individualism. Practically it will be extraordinary that fruit-growers of their own motion in any specialty unite and long coopperate to any end. They tie ropes of sand when they bind themselves to coöperation. They complain bitterly of excessive freight-rates, of 
dishonest commission men, of high cost of labor, of low prices and poor markets for fruit, of wind and weather, of man, beast, and corporations. If you decide to become a fruit-grower and come into the land a stranger, or, being acquainted, or even to the manor born, are an innovator, you are looked upon somewhat askance,-not wholly with enmity, but with a delicately tempered derision. When the college president turns politician, the bosses

"First loathe, then pity, then embrace."

So too when the man turns fruit-grower, the very old cherry trees nod their heads and wink their eyes and wrinkle the very toes of their roots, but gladly take the food the new master gives them and prick up their leaves and take on a new lease of life. The newcomer will find kind neighbors, but none who quite share with his vivid ideas of improvements. Fruit-farming has one traditional motto:

\section{In statu quo,}

which freely translated means,

$$
\text { As it was, is, and ever shall be. }
$$

The only incentive here is greater profit. Will it pay? I have never known a fruit-grower who deliberately declined an additional dollar of profit. If he sees that improved cultivation will produce the dollar, he will improve his cultivation. The 
neglected vineyards and orchards, in all fruit sections, belong to blind, deaf, and unreasoning men: for none are so blind as they who will not see. He may say that he sees, but he is merely repeating words he does not comprehend.

In our day the isolation and individualism of the farmer are vanishing; he is affected, as never before, by the world at large. Railroads, trolleys, motors bring fruit-growers into association. Seeing is becoming believing, and the presence of a well-managed estate in a fruit section works betterment of the whole region. Thorough cultivation tells its own story. No fruit-grower now lives far from the market; it is measured by accessibility, not by intervening miles. Necessity makes farm and market neighbors. Even if the market be a thousand miles from the farm it is no farther than the time taken to reach it and the cost of transportation. In the Lake Shore Valley the fruit-grower picks cherries, say a hundred or more bushels a day during the cherry season. Every afternoon at 3 o'clock he ships to New York; at 6 o'clock, to Pittsburgh. At 7 o'clock next morning his fruit is selling in these markets; by noon he has telegraphic returns. This means reduction of distance to lowest terms; it means more than this,-more cherries, better fruit, both on the farm and in the market; the grower better satisfied, the consumer too than ever before. It means a more careful selection of varieties; a closer study of the soil; a more thorough cultivation of the orchard. It 
means systematic and profitable farm management; a larger body of laborers, better wages, best type of packages, and highest profits possible. Not merely a bank account but a real fruit-farm; and a bank account because there is a fruit-farm. Sifted to real substance, it means raising cherries, and that depends upon cultivation. Feed the orchard and the orchard will feed you; care for the vineyard and the vineyard will care for you.

Thus the fruit-farmer now touches elbows with the rest of the world. He finds the whole in the soil beneath his feet. The world looks for cherries in the cherry tree, but the fruit-grower knows that he must first raise them in the soil and then cultivate them out of it. He must be ever in active copartnership with four associates:

\section{Nitrogen, Potash, Phosphoric Acid, and Humus,}

but his partners are helpless unless he drains the earth in which they work. He must drain top and bottom, and he must keep his partners busy. $\mathrm{He}$ makes his soil and it makes fruit for him. He trims, sprays, cultivates; he blankets the ground with a soil-feeding crop; he keeps it like an ash heap and filled with humus. Having climate on his side, his fruit-farm conveniently located, accessible, a well-made and a well-managed machine, an operating, chemical laboratory; his mind open to ideas from every quarter,-neighbors, journals, books, experiment stations, and he himself does a little 


\section{thinking on his own account,- - he will succeed in growing fruit in abundance, and the world will demand his fruit.}

\section{BIBLIOGRAPHY}

I select a few available publications of practical value in the matter suggested by their titles; similar publications are issued by other Experimental Stations, in various parts of the United States.

"Report on Tent Caterpillars." M. V. Slingerland, Bulletin 170, Cornell University Agricultural Experiment Station, Ithaca, N. Y. "The Codlin Moth." Bulletin I60, Ohio Agricultural Station, Wooster, Ohio.

"The Palmer Worm." M. V. Slingerland, Bulletin I87, Cornell.

"Notes upon Plums for Western New York." S. D. Welland, L. H. BaILEY, Bulletin I3I, Cornell.

"Treatment of Leaf-Spot in Plum and Cherry Orchards in 1896."

S. A. BeACH, Bulletin I17, New York Agricultural Experimental Station, Geneva, N. Y.

"Soybeans and Cowpeas." Bulletin 237, Wooster.

"Maintenance of Soil Fertility." Circular 120, Wooster.

- Circular 131, Wooster.

"The Maintenance of Fertility." Bulletin 182, Wooster.

"Soil Depletion in Respect of the Care of Fruit Trees." I. P. RoBerTs, Bulletin 103, Cornell.

"The Liming of Soils." Bulletin 159, Wooster.

- H. J. Wheeler, R. I. Agricultural Experimental Station, Washington, Government Printing Office.

"The Maintenance of Soil." Bulletin I4I, Wooster.

"Fall and Early Winter Injuries to Orchard Trees and Shrubbery by

Freezing." Bulletin 192, Wooster.

"Peaches for Home and Market." Bulletin 170, Wooster.

"Varieties of Strawberries." Bulletin 154, Wooster.

"Strawberry Notes, 1910-11." Bulletin 236, Wooster.

"Varieties of Strawberries and Raspberries." Bulletin 146, Wooster. "Orchard Culture." Bulletin I7I, Wooster.

"Orchard Practice: Starting an Apple Orchard." W. J. Green, Circular 108, Wooster.

"Pollination in Orchards." S. W. Fletcher, Bulletin I8I, Cornell. "Spraying Apples." Bulletin I9I, Wooster.

"Spraying for Fruit Diseases." B. T. Galloway, Bulletin 38, Washington, D. C.

"Spraying Experiments against the Grape Leaf Hopper in the Lake 
Erie Valley." Fred JoHnson, Bulletin 97, Pt. I., Washington, D. C.

- Johnson, Bulletin 116, Pt. I., Washington, D. C.

"Spraying Machinery." Bulletin 216, Wooster.

"Spraying Machines and Accessories." Bulletin 248, Wooster.

"The Regeneration of Orchards." Bulletin 124, Wooster.

"Seed and Soil Treatment and Spray Calendar, for Insect Pests and Plant Diseases." (Very valuable.) Bulletin I47, Wooster.

The Grape Rootworm, with Special Reference to Investigations in the Erie Grape Belt (Lake Erie Valley), 1907-1909. (Illustrated; very elaborate.) Fred Johnson, A. G. Hammar, Washington, D. C.

Grape Growing in the South. S. M. TRACY, Mississippi Agricultural Station, Washington, Government Printing Office.

"Principal Insect Enemies of the Grape." C. L. Marlatr, Bulletin 70, Washington, D. C.

“The Grapevine Flea Beetle." M. V. Slingerland, Bulletin 223, Cornell.

A New Grape Enemy: The Grape Blossom-Bud Gnat. Fred JoHnson, Washington, D. C.

"Self-Fertility of the Grape." S. A. BEACH, Bulletin 157 , Geneva, N.Y. "Fertilizing Self-Sterile Grapes." S. A. BEACH, Bulletin 169, Geneva, N. Y.

"Experiments in Ringing Grapes." W. PADDock, Bulletin 15I, Geneva, N. Y.

Fertilizers. (A most valuable treatise.) Edward B. VoorheEs, (late) Director of the New Jersey Agricultural Experiment Stations, and Professor of Agriculture in Rutgers College. The Macmillan Company.

Cyclopedia of American Horticulture. 4 vols. (Illustrated.) L. H. BaILEy. Macmillan.

The Fertility of the Land. I. P. RoBerTs, Macmillan.

The Soil. F. H. KIng. Macmillan.

Irrigation and Drainage. F. H. KING. Macmillan.

The Horticulturist's Rule Book. L. H. BAILEY. Macmillan. 


\section{VI}

FEEDING THE LAND

$\mathrm{A} \mathrm{S}$ all land is rock, more or less broken up, A pulverized, moistened by water and impregnated with what the chemists call "the elements," evidently, productive soil is plant-food stored in available form. Pure rock, solid or pulverized, cannot be called soil, yet a heap of sand, saturated with plant-food in liquid or gaseous form, will support plant life. This means that while man cannot make rock he can make or assemble soil. The process is simple enough in theory: to mix any earth with plant-food, such as may be needed. Nature is carrying on this process all the time. Heat, motion, electrical force (whatever that may be), break up the rock. Geological change, movements of water, ice (the glacial action), subsidence, rise of strata, the indescribable cataclysms of past ages, have transformed rock into earth and earth into soil. We cannot account for the elements. Mingling and commingling, they make life on the globe possible. The wisest thing we can do is to imitate nature. The process, in so far as we are 
co-workers, is physical. The great object with us is to get humus in the earth,-decaying vegetable matter in abundance. In other words, in order to have live plants, we must fill the earth beneath our feet with dead and decaying plants. The tree of a century's growth crashes to the earth in a tempest and, decaying, feeds a greedy vegetation, till it in various form matures, drops in death to the ground, decays, and feeds another round of plant life. The transformation of the dead and decaying oak into the wild vine, the dogwood, the artichoke, the hibiscus, the anemone, is a chemical, not a mere physical process. We cannot explain it. We witness the phenomenon and imitate it in orchard, vineyard, and field.

Soil for food purposes,-human food,-is no longer in the state of nature. The cultivated differs from the wild soil in degree rather than in kind. The wild soil is not so productive as the cultivated; the drain upon it to support plant life is less. This drain is dual: partly for the plant itself, the stock; partly for the fruit. The food for the stock is not the food for the fruit. In a wild state the plant stock gets more food than does the fruit. Our chief purpose in fruit-growing is fruit, not stock or foliage. In a wild state, the purpose appears to be the propagation, the continuation of plants, each after its kind. Nature does not raise fruit for market. We grow the fruit as it were at the expense of the plant; Nature grows fruit solely to perpetuate the kind 
of plant. Contrast the wild grape, or cherry, with the cultivated; the fox-grape with the Delaware; the black cherry of the woods with the Montmorenci or Morello or Tartarian of the orchard. We seek quantity and quality; Nature is satisfied with a fruit that will reproduce itself, irrespective of quality or quantity. She has done her perfect work when she has matured a seed that will grow and that actually does grow.

In brief, we use the land by converting it into soil that will produce plant or fruit (stem, leaf, root, berry, nut, seed, tuber, or pulp) finer in quality, larger, more abundant in quantity than will the wild soil. This means that fruit-growing is an artificial procedure. On one acre of cultivated soil we produce many times as much as will grow, in a state of nature, on wild soil. Therefore the supreme problem with us is how to make soil. We cannot change climate, but we can change, we can make, soil. Climate, soil, and the man make the fruit-farm. Given a climate which permits a plant to grow, man by manipulating the soil may bring the plant to what he calls a "state of perfection"- that is, to a quality and a quantity desired by him as food. In this process he may greatly. modify, and usually does modify, the original plant, even to sterility of fruit-seed, and to gross abnormality of plant stock. The supreme purpose is the production of food; or, viewed as truly from another angle, the supreme labor is the assem- 
bling of a soil and its constant use, care, and cultivation.

Stupid indeed is the would-be fruit-grower who ignores the soil, neglects cultivation, and yet expects fruit. He leaves the land wild yet demands fruit possible only from highly cultivated soil. As the supreme purpose in fruit-growing is fruit, the supreme rule is to do the things that end in fruit. Climate fixes the site of the fruit-farm. This site is never undrainable land, unless one intends to raise aquatic fruit, such as fish, ducks, or geese. A plant has two periods, ever in succession during the life of the plant: one of activity; one of repose. Its active period is the fruit-grower's opportunity. During this growing period, and then only, can it feed, assimilating food of such kind and in such quantity as shall produce leaf, stem, flower, root, tuber, seed, or pulp desired for food. Nor can the period of the growth be changed: there is a time, a limited, defined time in the year, during which the plant grows, if it grows at all. Spring and early summer are the period. The plant starts vigorously in spring but gradually ceases growth that fruit may mature and the plant be ready to renew activity another spring. This means that the plant is capable of feeding and growing only during a brief part of the year and, indeed, a brief part of its own life. Unlike an animal, a plant feeds continuously part of the year and rests the remainder. I mean, of course, plants of the temperate zone. For instance, no fruit plant cultivated in 
the open in the United States, such as peach, apple, cherry, grape, currant, or berry, grows the year round. That the plant while in a seemingly inactive state, as in winter, continues vital functions, there is no doubt. We do not yet understand them. Disturb these functions on a winter's day and the plant perishes as quickly as when they are disturbed in summer.

During the brief growing-period of the plant we make soil for its benefit,-or, more correctly speaking, make the food for the plant available in the soil. We cannot do this in winter or late autumn; we must feed it in spring or summer when it will take food; in spring rather than in summer because it then feeds most vigorously. Plainly then it is the fruit-grower who feeds his plants, he who makes his fruit. Begin as soon as the weather permits to feed your plantation. This means having your plant-food ready for the plant as soon as it awakens from its winter rest and begins to feed. This plant-food is not needed in the barn, or the packing-house, or on the truck wagon, but in the soil in available form. Plants have roots; roots and cells wonderfully organized and associated as it were lengthwise, beneath the skin or bark of the root. These cells have thin walls, which, if alive, have the power of absorbing moisture or gas. If this moisture is food, the roots take it up by a process known as absorption (endosmosis), new cells form, the plant grows; for a plant in earth below or air above is an assemblage of cells. When 
spring opens and the feeding process is active again (it doubtless goes on less actively during the winter), if food is available, the plant fattens fast. But this plant-food must be in liquid or gaseous form, for the plant-cell cannot absorb solid matter. It is the food already in the soil when spring opens that feeds the plant; therefore it is the food which the fruit-grower has made available long before the feeding process begins.

It is, as it were, food stored in the soil that feeds orchard and vineyard this year; for this year and next, and years afterward, do we reap the benefit of feeding the soil last year and years before. We feed the soil to-day that it may feed the plant to-morrow. How long will it take the plant-food you scatter on the ground to become available to the plant? Just as long as may be required to make this food supply soluble,-provided it really is plant-food. Iron is an ingredient of wood, but we do not fertilize an apple orchard with nails. The whole problem of soil-making is a problem of available, soluble plant-food. How long does it take a fertilizer to dissolve into invisible moisture and gas? If you can tell, then you know accurately when the fertilizer you apply to the land in form of ashes, lime, salts, barnyard manure, a green crop plowed in as clover, turnips, vetch, soybeans, grass, or weeds, will be fit to feed the plant. We can give a general answer: It will take as long as may be necessary for the fertilizer to become fluid or gas, and this is a chemical process 
within the laboratory of the soil. Heat and moisture are chief agents in this process. The sun really does the business. As well feed ingots of steel to a plant as an insoluble fertilizer. In perfectly cold, dry earth the process of change into soluble form is impossible. This explains the wonderful preservation of innumerable articles in Egyptian tombs for thousands of years, as honey, bread, seeds, cloth, wood, and other articles commonly perishable. During the winter the fertilizer we have already placed in the earth is rapidly becoming soluble. The earth is not so cold nor so dry, ordinarily, as to check this process. In coldest winter it is warmer than the air above; and in fiercest drouth it is moister, - otherwise, plant life as we know it could not exist on the earth.

Evidently soil-making is a constant process, though we are apt to think of it as going on only while we are applying fertilizers to the ground. The ignorant fruit-grower thinks of himself fertilizing the ground only while he is spreading some sort of manure over it. Foolish man! The alchemy of Nature never ceases. He may scatter a few pounds of fertilizer in the spring but his orchard will feed, can feed, only on the food then available in the soil and near the roots of the trees. Very possibly this food has been a century becoming soluble and this fertilizer he is now scattering may not become available for many years.

He may scatter a fertilizer, say nitrate of soda, which speedily becomes soluble; or, say lime, which 
becomes soluble only in centuries. The hills which wall in the Lake Shore Valley along the south (and this Valley may be used as a basis for comparison with other favored fruit regions in America) are, as I have said, based on sedimentary rock filled with fossil shells of the Devonian and Carboniferous ages. The entire body of hills is raised land so that the layers of sedimentary rock, composed largely of these shells, are some seven hundred feet above the plane of the Valley. For untold millions of years the waters from the springs high among these hills have been seeping through these thick layers of shells, dissolving them and, flowing northward across the Valley, both along the surface of streams and through wide, subterranean rivers, have impregnated the whole Valley with lime. Where this ooze of water trickles over the rocks along the bluffs that face the lake, the impure lime is deposited in fantastic shapes. Only a few days ago, in company with two friends, I was revisiting the largest of the gulches that cut the hills from south to north and northwest. This is known as Gage's Gulf and, lying partly in New York, partly in Pennsylvania, runs some sixteen miles, in all its turnings and windings, from the crest of the hills, where it starts in a meadow by the roadside, to its mouth, and discharges into Lake Erie. All day we enjoyed its wonders of formation, and fossils - animal and vegetable. In the bed of the creek we picked up these vestiges, millions of years old, washed down by the fierce 
currents of breaking spring; tossed down from the dizzy sides of the gulf by frost and trickling stream. Nature is still dissolving this immeasurable mass of dead oysters, clams, and snails, creatures of the dawn of time. Corals too in profusion, some like long lily stems, some like horns of plenty, all imbedded in the rock-hard, igneous rock,-the fires of chaos and old night having imprisoned them forever. No labor of sun or rain can now dissolve these corals, or free them from the embrace of flint and sard. But the inexhaustible heaps of shell are plant-food for ages to come, so long as the Valley can be the seat of life. . Sixty millions of years, yes, for a hundred millions has Nature been dissolving these beautiful shells, each the sheath and skeleton of a mollusk of yesterday's yesterday. The process is no speedier to-day in your cherry orchard when you spread the lime. Scatter lime over your fields and centuries hence Nature will still be at work dissolving your lime and trying to make it available for plant-food.

If we reflect but for a moment we can understand that any application of fertilizer we may give the land must be inert until heat and moisture and air, both above and below ground, have broken down the fertilizer, pulverized it, changed it into liquid and gas, and so made it fit for absorption by the delicate cells of the plant root.

Soil-making consists then in putting on raw material for plant-food, to be assimilated years, centuries, perhaps ages hence; or, it has been put 
on ages ago. There is nothing new in the process. Our trees, vines, orchards, and plants are growing because plant-food, deposited in former times, is now soluble and available. The plant feeds as it were at both ends-top and bottom, root and branch. We speak of the leaves as the plant's lungs; of the roots, as its stomach,-rather strong metaphors. The leaf is an arrangement of cells which both receive and give out gas. Some plants are "air-feeders,"- - not many however; the mistletoe, commonly called an air-plant, sending quasi-rootlets into the bark of the tree and so feeding on the sap. Yet we know that a common and trustworthy test of tree-health is foliage. An abundant, well colored foliage means a healthy tree. If we submerge the foliage in water or in a poisonous gas, the leaves, and usually the tree, die. We have starved the tree by cutting off its supply of food by means of gas or water. In like manner we starve the tree were we to submerge the roots. Cut them off from soluble food and they, as well as the tree, perish. Pack the roots in barnyard manure, or ashes, or nitrate of soda, or iron filings, or olive oil, or old clothes, and we starve the tree. Fill a man's stomach with mustard, or roast beef, or plum duff, or any like morsel of like solubility for infantile digestion, and we starve the body. though the process is somewhat accelerated "by other symptoms setting in." Many a tree and vine on the plantation dies of starvation through "auto-intoxication," which, translated, means 
"self-poisoning." We do not commonly think of a whole peach orchard going off on a spree, say on brandy-peaches, but we may, and sometimes do, in our ignorance, intoxicate the trees to their death. The ignorant grower poisons or starves his own orchard. Thus, seeking figs and finding none, he condemns the tree as unprofitable, overlooking his own contributory negligence. He insists that it do double duty, - send forth new growth of wood and fruit abundantly on an empty stomach, or, at least, on short rations.

But some one may ask: "If it takes centuries to get fertilizer into plant-food, what can the fruitgrower hope to accomplish? He cannot go back to the Devonian age, or to the time of the American Revolution, and fertilize his ground." True, he cannot go backward (though his orchard may), but he can go forward. He can make soil faster than does Nature in the wild; he can apply fertilizer which will dissolve and become available as plantfood in far less time than the fossil shells which seep as lime-water through his land, from the hills. And herein lies the claim of all commercial fertilizers, that they dissolve rapidly in the soil; this is their chief merit. All forms of decaying plants as fertilizers, - such as grass, clover, vetch, beans, weeds, straw, barnyard manure - which is largely straw impregnated with animal excrement,-require considerable time to become soluble as plantfood. "Considerable" may here mean from one to five years, as the earth is warm and moist, or 
cool and dry. Heat and moisture break down the cells of such fertilizers, hence the necessity of burying them. Spread over the surface and left there, they decay more slowly than when plowed in,- as every farmer knows. He also knows that a heavy application of such fertilizer well plowed in produces more effect the second than the first year. Straw-the typical fertilizer of this sortdecays as humus and helps keep the earth moist and porous, and in chemical activity. But the tons of such fertilizer become soluble plant-food gradually and in a relatively long period of time. In proof of this one may cite the effect for years of applying barnyard manure to a field. This means that it becomes soluble plant-food slowly. The fertilizers help keep the soil making. Like the miller, you merely keep the hopper full, the grist grinds on and turns out flour. You keep the soil filled with matter which will dissolve and become available plant-food. This is all you can do. You yourself cannot effect the chemical change. All you can do is to supply raw material; Nature does the rest. The earth is only a porous crucible in which heat and moisture convert salts, acids, grass, straw, weeds,-whatsoever is soluble,-into plant-food. The plant itself is selective. "Each after its kind" is the rule. Grapevines, strawberries, peaches, have each its appetite. The art of fruit-growing is to know this appetite and how to satisfy it.

Practically, whatever the plant, tree, vine, shrub, 


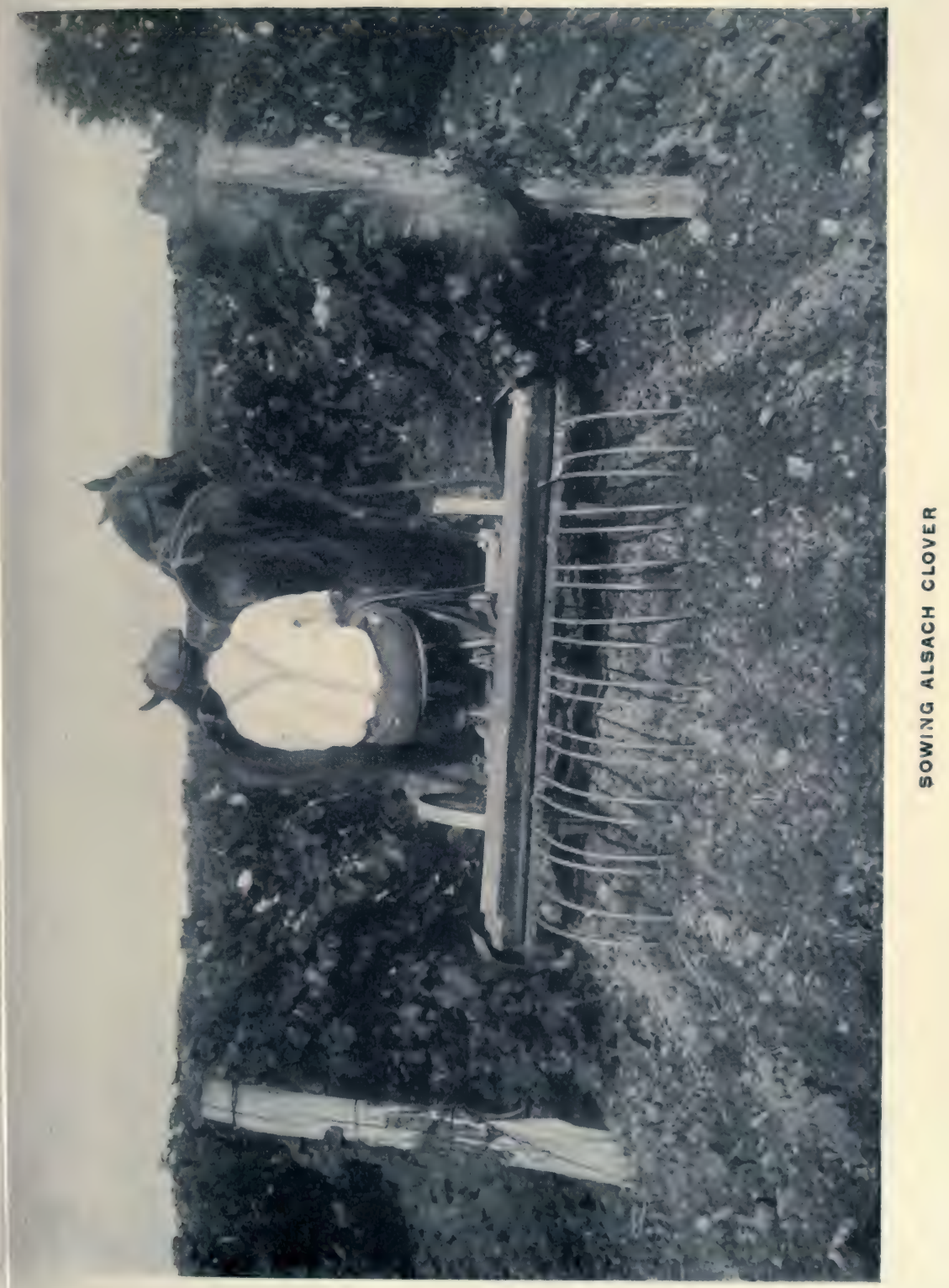



or root, the preparation of the soil for plant-growth is the same - to conserve plant-food in form of moisture. There is a difference between water and moisture. Most plants will live for a time seemingly on pure water, but in truth only so long as the supply or stock of food already in circulation in them lasts; for pure water is not a complete plant-food. Each plant needs a continuing supply of the elements of which it is composed. Thus, stating the case broadly, the chemistry of feeding the plant for fruit means a supply of soluble potash, but for leaf, stalk, or stem, a supply of soluble, or available, nitrogen. The air about us is composed chiefly of nitrogen, but so firmly fastened to the oxygen and hydrogen as to be unavailable to the plant. Doubtless the leaf, during its growing period, has power or, so to say, is functioned to disassociate the nitrogen from its companions. As yet we have no cheap, abundant, available nitrogen in form of fertilizer, available as plant-food. Here is the chemist's opportunity. Let us ask the men in the great chemical laboratories, equipped by private or by public means, at Berlin, at Washington, or at the university, to discover, if they can, a form or compound of nitrogen, abundant, cheap, easily handled and applied to the land, and speedily soluble in the soil as plant-food. This accomplished, wheat and corn and potatoes and beef and mutton and the long list of human foods will drop in price. Man will go up and food will come down. Here is the opportunity of the industrial chemist. He may 
not realize that farming is behind time. Food must be kept cheap enough for every human being to have enough. Not necessarily fewer autos and victrolas and moving pictures, but more nitrogen for farm use.

Who said "hardpan"? Did you discover, before you bought your land, whether it rests on hardpan and how far it is to the hardpan? You may be buying a tight, shallow dish; a hardpan basin covered with a few feet of earth in which water collects and drowns the roots of orchard and vineyard. A grapevine or a tree spreads as much root below as foliage above ground. The vine will shoot forth innumerable roots down into the earth, some to the distance of twenty feet. If your soil is shallow and rests on hardpan, it will flood and drown at bottom and bake at top, unless you keep the pores and capillaries open and also get rid of the water. By piercing the hard layer which forms the "pan" you may possibly reach coarse gravel and so drain your land, or the dip of the "pan" itself may give ample drainage. Commonly the strata beneath dip or incline and the superfluous water runs down hill and away. If you expect to raise fruit, or indeed any field-crop, you must get rid of the water. Moisture in the earth is like oil that climbs up the lamp-wick and feeds the flame; moisture rises by capillary attraction in the earth and helps dissolve whatsoever it finds into available plant-food; it feeds the flame of life in the plant. If your land is hard, thin, poor, wet, 
undrained, this capillary movement of moisture cannot go on. No tree or vine can thrive in such earth; you must first convert it into soil. The first step is drainage; the next step is drainage; the last step is drainage. Whatever the aspect of the fruit-farm, sooner or later we come to drainage. No drainage, no soil; no soil, no plant; no plant, no fruit. Perfect drainage means a responsive soil. Plowing, spading, cultivating, fertilizing, are in vain without drainage. Most lands have natural drainage, but too sharp incline of strata means wash and waste. Could a transverse section of the land be made, on your farm, to a great depth, say of three hundred feet, you would doubtless discover a succession of rock strata at bottom, then coarse gravels, clays more or less porous, then mixed gravel and fine clay as loam, and, at top, the soil as we commonly know it. The many gas wells which have been sunk in the Valley give us this knowledge. Land that can dispose of all ordinary rainfall without washing or flooding is well drained. Of two evils, a dry soil or a wet, the dry is preferable; for cultivation gives moisture, but standing water makes any land untillable. Land which, untilled, is hard, dry, and bare, may be made highly productive by cultivation,-stirring the earth makes it porous, sets capillary action free, converts the wild into a garden, By this breaking up, gases and liquids in the earth go down and moisture and gases rise. In brief, circulation sets in. Earth must be aired, aërated, like bread, 
in order to become light, or like a feather-bed, to be kept wholesome. If you examine a well-tilled field on a sultry day, or amidst drouth, you will discover that the dusty surface covers a moist, porous, warm, productive soil. Scratch but with your finger and you reach moisture. This is an ideal setting for plants. The ground cannot be kept too porous, or circulation too complete. We avoid peril to the plant, or to seeds, by setting or sowing root or seed down moisture deep. The moisture-gage measures all plant-growth.

It follows then that artificial watering is the basest abuse of the soil. It gives wind and sun a chance to bake the surface; it fills the earth-pore and drowns the plant's roots. The best wateringpot is a hoe, a cultivator that stirs the surface of the ground. No thoroughly tilled soil needs irrigation. Dry farming is best farming. Plants differ in habits, but every plant on the fruit-farm prospers by cultivation. Take the trouble to overturn a stone, a bit of wood, an old carpet, the board in front of the kitchen steps, even a bunch of hay or straw lying on the ground over nightthe earth beneath is moist. Cover the soil with fertilizer and you catch and retain the moisture as it exudes from the land. You stop it on its way from earth to air. You make a like cover when you stir the surface with cultivator or hoe. The thoroughly tilled soil stops the moisture on its way to evaporation. So by stirring the ground frequently, hoeing the garden often, running the 


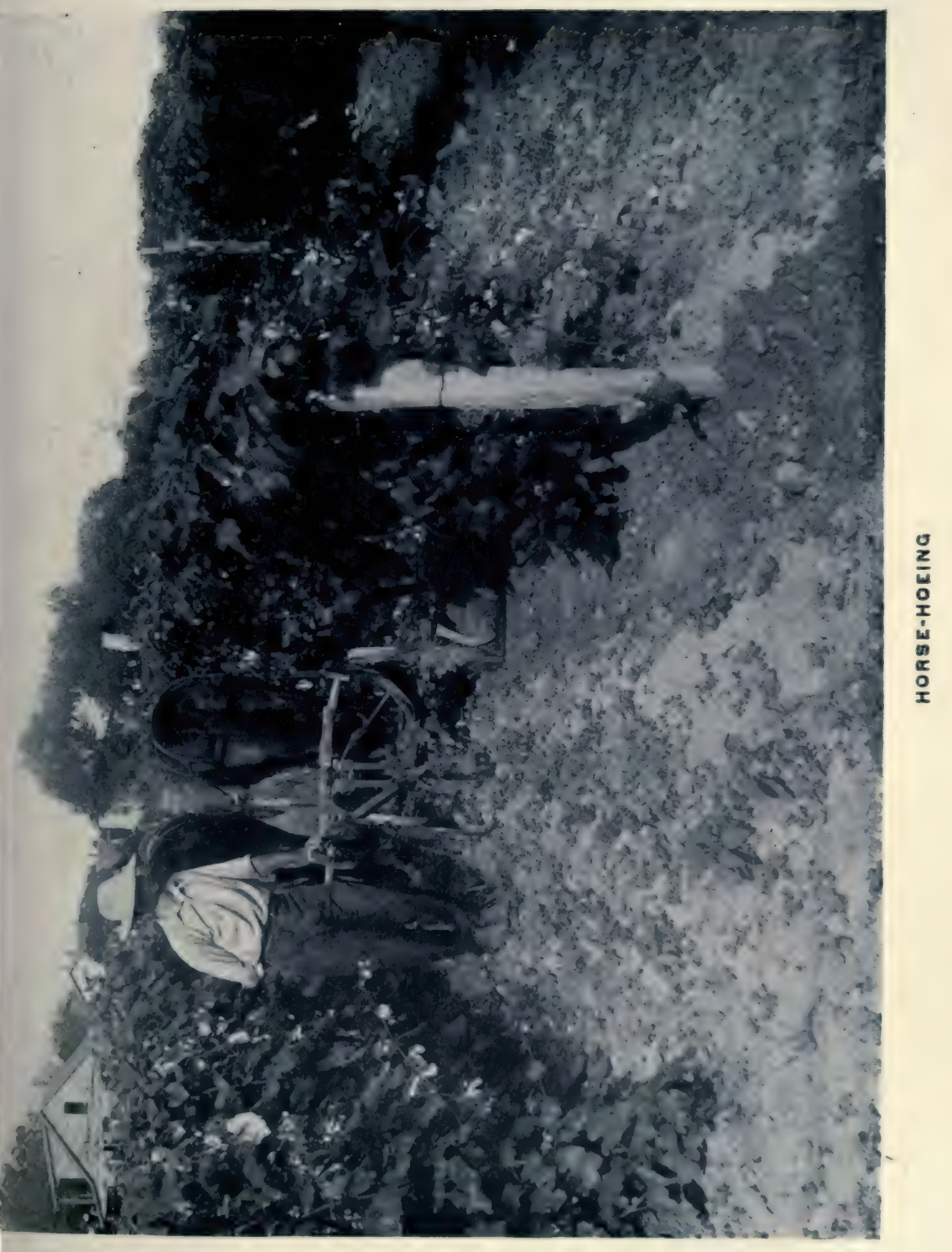



cultivator through the corn, the orchard, the vineyard, the berry patch, you conserve moisture for the plant-roots. This ordinarily, but the time may come when cultivation is but stirring the dust. Then water is in order, not a sprinkling, but the soaking of the soil, deep, copious, complete. Afterward, and as soon as you can work the land, stir it thoroughly with cultivator or hoe; you will thus put a cover over it and prevent the thirsty sun and the greedy wind from draining it as dry as hay. This thorough cultivation is only a form of surface drainage. Somewhat curious to say, soil, to be most productive, must be drained top and bottom. The composition of the earth is not of great importance; loam, clay, gravel, stone, or sand, if doubly drained, and supplied with soluble plant-food, and located within the climate belt for fruit,- such land, various in context, is ideal and will produce fruit of finest quality and in great quantity. Such a soil is a chemical laboratory which turns out apples, cherries, grapes, peaches, prunes, pears, currants, and berries of every kind.

Nature is economical and thrifty, ever providing for her own at long range. In any fruit valley the preparation for fruit-farming has been going on for millions of years. What an inconceivable tonnage of ripened foliage, leaf, stem, stalk, of fruit itself, has fallen to earth in this Valley and become plantfood! What an immeasurable atmosphere has fed this upper world of plant life! And what incomputable weight of mineral matter in the earth has 
disintegrated, dissolved, changed from solidity to fluid and gas and has fed this spread of root! Cycles of geologic time mean no more than leaf, bud, flower, and fruit to the plant, and ever that the same organ or part of the plant may be capable of perpetuating its kind-of repeating its life history. Nature may not succeed, but ever essays immortality of flora and fauna. Doubtless in some later geologic age, æons hence, this planet will be clothed with a plant life as different from this we know as is this from the plant life of the Age of Fishes or of the Coal Measures.

However, our business as fruit-growers is not with palm trees and gigantic ferns which turn into anthracite, or with trees of ages hence which may turn into dynamos. Our business is with the tree and vine of to-day; to respect its habits; to feed it well, and ourselves to feed on it. Nature teaches us how to mix our soil for what we call profit. But Nature and we have somewhat different purposes. She makes soil solely to perpetuate plants, each after its kind; we make soil solely to raise fruit-that is, what we call fruit,-not, as Nature would say, the seed that will reproduce the plant, but the fruit we use as food, which in our apple, peach, grape, cherry, prune, currant, or berry is not the true seed but the pulp that grows or forms about the seed, primarily as nourishment when the seed shall start to germinate. Therefore a fruit-farm is really a pulp-garden. The edible part of our fruits is the pulp. We throw 
away the true seeds of apple, peach, grape, berry, - the pit, or stone. The plant-food we are seeking is really pulp-food. We prefer seedless apples, strawberries, currants, grapes; pitless cherries, peaches, prunes; and we measure our horticultural skill not by the size of the true fruit-the seed or pit or, to be accurate, the kernel within the husk or shell or skin, but by the quality, the color, the quantity of the pulp which envelops the true fruit. Nature, left alone, grows little pulp, but expends her energies on kernel, shell, or husk. We cultivate the pulp and try to make the kernel atrophy. So we fertilize and cross-fertilize, bud, graft, mix, and breed to secure the peach with the smallest freestone and the largest, most luscious and attractive pulp.

Happily barren, dead land is rare. Poor land is comparatively rich. A fair test of land is the weeds it will grow. A soil covered with tall, thick, dank, glossy, blooming weeds means a rich soil. Change weeds and you raise tobacco, tomatoes, trees, potatoes, cabbages, vines. Barren land may be rich in minerals of the kind which, in soluble and limited form, feed plants. A bed of pure nitrate or phosphate would not support plant life any more than one of pure carbon, oxygen, or nitrogen, salt or iron would support animal life. Yet a sprinkling of nitrate of soda sets a plant bounding into leaf and stem, and a pinch of potash, soluble and fed to the tree or the vine, paints peaches crimson and grapes purple. The soil 
seemingly dead, yet rich in minerals, supports a luxuriant plant life by the addition of vegetable matter-that is, of decaying plant fiber or humus. This is the sign of the right sort of soil: abundant humus. It is the essential which no commercial fertilizer can supply. Dead trees make living trees possible. Dead plants are the bed of vegetation. Lose the humus from your soil and the earth is no more productive than a pit filled with iron filings. Therefore, fruit-grower, in all your getting, get wisdom and understanding as the Book of Books advises, but be sure also to get humus.

We know little of the secrets of plant life. We cannot see the grass grow or hear the doors of the flower open. Yet we know that soil devoid of humus is inert. The two components of the perfect soil are vegetable and mineral; the vegetable includes the animal, but never the mineral, though mineral ingredients enter into every plant. Perhaps we are merely using words without meaning, but what we really try to say is that the elements known in nature in part compose the fruitful soil; that in one familiar form these elements are humus to us; in another form, they are mineral. Whichever way the truth is expressed, we know that when we attempt to raise fruit our soil must be rich in humus, which to us, plain fruit-growers, seems to be the decaying vegetable matter in the earth. If abundant, this humus keeps the soil moist, porous, chemically active, and productive. If humus be lacking and the mineral ingredients 
only abound, the land is hard, dry, lifeless. Combine humus and mineral, heat and moisture and cultivation, you will make the desert blossom like the rose.

Now every tree, vine, shrub, and root is a consumer of mineral matter, sending its roots downward in search of food. Sideward also the roots run, and often surfaceward also. The heat and moisture in the soil break down humus and mineral matter, making both soluble and thus converting both into plant-food. We have both humus and mineral matter in tree and vine, shrub, tuber, and root. Here again the law is working: "Each after its kind." Trees and vines pierce the soil to a great depth as compared with berries, tubers, and cereals. This means that the depths of the soil, not its surface, are the feeding ground for orchard and vineyard. Here is the cue to the fruit-grower's lines; the culture of orchard and vineyard differs from that of grain-field or truck garden. But how shall we get plant-food deep down in the earth? It is not found there as abundant as nearer the surface. Yet we know that earth that is brought up from deep wells and shafts will support plant life, and that germs, buried for ages, burst forth into plant life when thus exposed. We know that deeply buried seeds have great vitality, not because they have been, deeply buried, but because they are living germs, long carefully protected by nature against decay, and in condition to grow at opportunity. Doubtless all earth 
which constitutes the shell or husk of the planet, the shell between the molten mass within and the atmosphere without, will support plant life. But neither tree nor vine penetrates these depths. All our vegetation is superficial, keeping ever within the range of the sun's heat on the surface of the earth. Thus the active range of root-life is very limited, as is the range of foliage life. Indeed, foliage may be said to rise and roots to spread. Trees and all vines and shrubs grow literally on the surface of the earth. In Alaska the subsoil remains frozen and marks the impenetrable limit of root-spread. There roots grow laterally, not deep downwards. All this hints at the proper activity of the fruit-grower: to till the soil, not to burrow in the earth, or to bury plant-food too deep. Gravitation draws all supplies downwards; the sun and capillary attraction draw them upwards. Gravitation drains the soil below; the sun drains it above. It is a perpetual game of shuttlecock between these two forces which dominate all life on the globe.

No man can utilize more food than he can assimilate, and plants are like men. All that is given the plant more than it can absorb must lie dormant, or waste. We can send tons of good fertilizer on a profitless journey toward the centre of the earth, and not one ounce of food for man be gained. The fruit-grower must know what kind and what amount of food to supply his orchard or vineyard, just as the mother of the house must know how to 
supply her household. While doubtless in nature nothing is actually wasted - that is, completely destroyed and eliminated from our universe, the ignorant fruit-grower may put what he imagines is fertilizer on his land and realize no benefits. Each after its kind is the law. He may feed for treegrowth and starve for fruit-growth. In other words, his dietary may not be at all adapted to his fruit-farm.

I have heard vineyardists declare that were they to be offered as a gift enough barnyard manure to cover their vineyards a foot thick, and it were delivered and spread, they would decline the offer. I have heard another say that he would not accept as a gift a foot depth of commercial fertilizer on his vineyard but would prefer even a light application of barnyard manure. A third has shown me his vineyard on which he said that for eleven years he had not put a spoonful of fertilizer of any kind, and that he declined six hundred dollars an acre for it. A few years later he died and the land was sold by the heirs for slightly more than half this rate, the apparent fall in price being caused not by any asserted deterioration of the land but because the heirs did not care to have a vineyard. But nevertheless this "spoonless" vineyard had not maintained its original record for production; it had fallen off in eleven years of starvation some fifty-three per cent. One of the vineyardists who so roundly rejected, or would reject, barnyard manure, lately informed me that his vines were 
light; the growth of wood scanty; the leaf color bad; the fruit small and scraggly, and the production about one third of the amount during the first five years. There is never enough barnyard manure to go round, save as is the case with the owner of one estate, who being a high official of the Lake Shore Railroad sends to his fruit-farm carloads of manure from the Chicago stockyards and scatters it a "foot deep" among his vines. These show heavy growth of wood; rich, large, glossy leaves; and produce abundantly. Hence, after some experience, I abide by my judgment that, while fertilizer factories doubtless bring blessings in dividends to stockholders, we who try to raise grapes get and keep healthy vines and raise grapes abundantly as we cover our vineyards with barnyard manure as nearly a foot deep as may be. Not being able to secure fertilizer in this form, we substitute cover-crops, as of clover, vetch, or turnip, which we plow in, and add phosphates, nitrates, and potash in such quantity as in our selfishness we may think necessary.

That soil is a chemical laboratory in which Nature perfects the transformation of mineral and vegetable matter into available plant-food makes life possible on the globe. It is a vast and singular conclusion of the oldest science-astronomy,that the life we know and see about us on this planet and of which we are part, is limited to this planet alone,- - to this earth, this globe, this grain of sand in the universe. Most awesome the thought 
that no other world, even if it has life, can have this our life of flower and shrub, of orchard and vine, of bird and beast and man. We are alone in the vasty deep of space, coming whence, going whither, living our span, thinking, doing, fitted for no other habitation in the commensurable world than this our home. And here the chemistry of the soil is the physical basis of life. We are not the chemist; ours is not the laboratory. We may toss pigmy portions of the elements about, scratch the surface of the earth with a pin, drop seed in a hole, or plant a root in a crack. The chemical processes go on despite our petty activity or our valorous ignorance. If we plant the seed or set the root with Nature, she cares for it, feeding it bountifully; if we are indifferent to her, she treats us and seed and root as mere elements to be agents or re-agents in her crucible and to become available food for the perpetuation of life on the globe, each after its kind.

Helpless, bold, carrying our lives in our hands we must turn to the ground for our existence. It is the laboratory in which every work of man is latent. We discover that for our purposes and ends the soil should be as it were charged with plant-food. It is a case of intensive chemistry. For purposes of perpetuating plant life, each after its kind, the intensiveness is not required; but for our purposes, to secure food in the form we desire, the soil must contain three elements in larger quantity than that in which they are usually found in the wild: potash, phosphoric acid, and nitrogen. New land, 
as prairie or forest-clearing, river-bottom, or bed of ancient lake, usually is seemingly rich in all three. Ages of soil-chemistry - of disintegration of mineral and of decay of vegetable matter-have stored up these foods.

The land newly put to human use is a depositary of pent-up energy, which, set free on demand of seed or root dropped into the soil, is transformed into wheat, corn, oats, potatoes, roots, berries, orchards, and vineyards. Every farmer knows the superior crop-value of new land. He who has had experience in clearing off timber, planting the new land, the first year to potatoes, the second year setting it to Concord grapes, will record an extraordinary yield of potatoes, both as to quantity and quality of fruit, and also a phenomenal yield of grapes for several years. I have known a production of nearly eight tons of grapes per acre from such land for several years in succession. This heavy production was the cream of the land; the skim-milk followed when the foods, stored up for ages in that land, had been exhausted. Soil in the wild is soon depleted,-reduced to lowest terms of productivity by cropping. Cropping is wanton consumption of plant-food without resupply. Happily, on this new land, the grower grew clover to plow in, and applied phosphates and potash, thus warding off the evil day of plant collapse. Cropping the land is like drawing all your money from the bank and winding up with an overdraft. If we will de- 
posit heavily of fertilizers we need not worry about cropping.

We must keep the true balance in our soilaccount by applying potash, phosphoric acid, and nitrogen. So long as the soil is kept rich in these elements, together with humus,-ever, ever humus,-it remains practically inexhaustible. When we clear land and burn timber, stump, and brush, and scatter the ashes over the soil, we return potash in the ashes, and ashes, as the farmer says, last a long time in the ground. But wood-ashes, unleached, from hard wood, are scarce. We can supply potash by using commercial fertilizers,-as muriate or sulphate of potash, a plant-food readily becoming soluble in the soil. The amount to be applied depends upon the need of the soil. A moderate quantity every year is better than a heavy application infrequently,- say once in three years. Three hundred pounds of the muriate (the sulphate is stronger) to the acre is ample unless you wish to force the plant and, possibly, to waste your fertilizer. As it is insoluble in the air, it can be applied in winter; drawing to field on the sled and scattering about on the snow. It may well be remembered that the roots of tree or vine extend more than a mere foot from the trunk and that the entire area between rows may wisely be scattered over with the fertilizer. Moreover there is danger of burning the stock if strong commercial fertilizers are heaped around it.

Phosphoric acid may be had commercially in 
the ground-bone fertilizers, or in pulverized or dissolved Florida or South Carolina rock. An annual application of four hundred pounds to the acre, or more as the soil may indicate its needs, is ample. I incline to the heavier application, even up to twice the amount named. Nitrogen, though the most abundant element in earth and air, is usually in an insoluble form. We get it from the earth indirectly, through the clovers, vetches, cowpeas, beans, turnips, and root-piercing crops generally. These absorb the available nitrogen in nodules, as the clovers; or store the element in the fruit, as in peas and beans, and thus make the food available. A piece of hard, barren land, if sown to one of the clovers and securing a good "catch,"that is, the seed growing,- - with favorable weather, becomes a green field. Plow in the clover, and the land by so much becomes rich and tillable loam. Sometimes these plow-crops are not practicable, and resort must be had to commercial fertilizers for a time, in the form of animal refuse, blood, tankage, and nitrate of soda. But Nature herself comes to our relief. What spot does she leave barren on hill, or meadow, or beach of lake? The nakedness of yesterday is clothed to-day with grass and weeds and creeping vines. Nature not only abhors a vacuum but also barren earth.

These foods-potash, nitrogen, phosphoric acidslip quickly through the earth and may wholly miss the mark unless stayed in their flight, held up, as it were, by humus. This delays them till the 
plant-cells can absorb them; whence it follows that the more soluble the fertilizer, the greater care necessary in applying it at the proper time, and in quantity precisely measured by the absorptive and feeding powers of the plant. This means, feed the plant most when it is capable of consuming most. The nitrates feed stalk, stem, and leaf, therefore feed them when leaf, stem, and stalk are growing, when foliage cells are most rapidly forming. Potash is fruit-food, therefore have it at hand when the fruit is forming. Nitrate of soda would be wasted in late summer, in autumn, or in winter. Nitrates are spring foods, to be applied when the plant is growing rapidly, whether in spring or early summer. But fruit is forming while the plant is growing, so potash must be applied in time to feed the fruit; it must be on hand, in the soil to that end. How long nitrates or potash will remain in the soil awaiting solution depends upon the moisture and temperature of the land. These being low, solution is slow; if very low, it proceeds not at all. But as potash is more insoluble than the commercial nitrates, it may be applied in winter, or late autumn. All commercial fertilizers are artificial and must be applied timely, evenly, discreetly. They are like stimulants to the human body, to be used with care. Dropped in lumps and masses on the ground, they waste in sun and wind, or remain inert, like rocks piled by the roadside. Brought into raw contact with the roots of the plant, they char, poison, burn, shock the root- 
cells, and are no more helpful to the vine or the tree than hot coals or iron pigs.

I prefer the processes of Nature, on the fruitfarm, to the laboratory at Cornell, or the factory in Buffalo, or Chicago. Cover-crops, such as the clovers, plowed in, supply nitrogen; ashes supply potash and some other ingredients, as lime. Phosphoric acid is supplied by stable manure, by guano, by South Carolina or Florida rock, or by ground bone. $^{x}$

The average composition of the most important farm manures and of the commercial fertilizers is shown by the following tables:

\begin{tabular}{|c|c|c|c|c|c|}
\hline Farm Manure & Nitrogen & Ammonia & $\begin{array}{c}\text { Equiva- } \\
\text { lent }\end{array}$ & $\begin{array}{l}\text { Potash } \\
\left(\mathrm{K}_{\mathbf{2}} \mathrm{O}\right)\end{array}$ & $\begin{array}{c}\text { Phosphoric } \\
\text { Acid } \\
\left(\mathrm{P}_{2} \mathrm{O}_{5}\right)\end{array}$ \\
\hline Cow manure (fresh) & 0.34 & $0.4 I$ & & 0.40 & 0.16 \\
\hline Horse " " & $0.5^{8}$ & 0.70 & & 0.53 & 0.28 \\
\hline Sheep & 0.83 & 1.00 & & 0.67 & 0.23 \\
\hline Hog & 0.45 & 0.54 & & 0.60 & 0.19 \\
\hline " 4 & 1.63 & 1.98 & 0.85 & I.54 & \\
\hline Mixed stable-manure & 0.50 & 0.60 & 0.63 & 0.26 & \\
\hline
\end{tabular}

Commercial Potash Fertilizers: Average Composition of Potash Salts:

\begin{tabular}{c|c}
\hline Name of Salts & Average \% of Pure Potash \\
\hline (A) Salts containing chlorides: & \\
Muriate of potash & 50 \\
Manure salt & 20 \\
Kainit (crude salt) & 12.4 \\
(B) Salts free of chlorides: & \\
Sulphate of potash & 50 \\
Sulphate of potash-magnesia & 27 \\
\hline
\end{tabular}


While the grower is feeding the soil, the crops are taking many tons of ingredients from it in the form of straw, - that is humus, growth of wood, twig, branch, and vine, leaf, stalk, and flower; potash, nitrogen, and phosphoric acid. The amount of material thus actually abstracted by the

Commercial Phosphoric Acid Fertilizers: Composition of Fertilizer Materials Used as Sources of Phosphoric Acid:

\begin{tabular}{|c|c|c|c|c|}
\hline & Nitrogen \% & $\begin{array}{l}\text { Equivalent in } \\
\text { Ammonia \% }\end{array}$ & $\begin{array}{c}\text { Potash } \\
(\mathrm{K} 2 \mathrm{O}) \\
\%\end{array}$ & $\begin{array}{l}\text { Available } \\
\text { phosphoric } \\
\text { acid \% }\end{array}$ \\
\hline $\begin{array}{l}\text { So. Carolina acid phos- } \\
\text { phate } \\
\text { Florida acid phosphate } \\
\text { Tennessee acid phosphate } \\
\text { Bone black dissolved } \\
\text { Bone meal } \\
\text { Bone dissolved } \\
\text { Peruvian guano }\end{array}$ & $\mid \begin{array}{cl}2 \pi / 2 & \text { to } 4 \pi / 2 \\
2 & \text { to } 3 \\
6 & \text { to } 10\end{array}$ & $\begin{array}{l}3 \text { to } 51 / 2 \\
21 / 2 \text { to } 31 / 2 \\
71 / 4 \text { to } 12\end{array}$ & I $1 / 2$ to 4 & $\begin{array}{l}13 \text { to } 141 / 2 \\
13 \text { to } 16 \\
15 \text { to } 18 \\
16 \text { to } 19 \\
6 \text { to } 9 \\
13 \text { to } 15 \\
7 \text { to } 8\end{array}$ \\
\hline
\end{tabular}

The Nitrogen Fertilizers: Composition of Fertilizer Materials Used as Sources of Nitrogen:

\begin{tabular}{|c|c|c|c|c|}
\hline & Nitrogen \% & $\begin{array}{l}\text { Equivalent in } \\
\text { Ammonia \% }\end{array}$ & $\begin{array}{c}\text { Potash } \\
(\mathrm{K} 20) \\
\%\end{array}$ & $\begin{array}{c}\text { Phosphoric } \\
\text { Acid }\left(\mathrm{P}_{2} \mathrm{O}\right) \\
\%\end{array}$ \\
\hline Nitrate of soda & $151 / 2$ to & I9 to $191 / 4$ & & \\
\hline Sulphate of ammonia & $193 / 4$ to & 24 to $251 / 4$ & & \\
\hline Dried blood & $\begin{array}{c}\text { I0 } 1 / 4 \text { to } \\
143 / 4\end{array}$ & $121 / 2$ to 18 & & 2 to 3 \\
\hline Concentrated tankage & $121 / 4$ to 13 & 15 to 16 & & I to 2 \\
\hline Tankage & $7^{1 / 2}$ to 9 & 9 to II & & 7 to 9 \\
\hline Bone tankage & 5 to 6 & 6 to $71 / 2$ & & $91 / 2$ to 15 \\
\hline Dried-fish scrap & 9 to 10 & II to 12 & & $51 / 2$ to 7 \\
\hline Cotton-seed meal & $61 / 2$ to $71 / 2$ & $71 / 2$ to 9 & I $1 / 2$ to 2 & 2 to 3 \\
\hline Castor pomace & 5 to 6 & 6 to 7 & I to $\mathbf{I} / 2$ & I $1 / 2$ to 2 \\
\hline Tobacco stems & $21 / 2$ to 3 & 3 to $3 \pi / 2$ & 2 to 10 & $3 / 2$ to $I$ \\
\hline
\end{tabular}


crop from an acre of land varies, according to the crop, from one to five tons of straw, or its equivalent; from thirty to two hundred pounds of potash; from four to seventy pounds of phosphoric acid, and from thirty to two hundred pounds of nitrogen. Of course the greater part of every crop is water, whether it be twenty tons of onions, four hundred bushels of cherries, two tons of grapes, or thirty bushels of beans. If, for example, thirtysix tons of cherries be harvested from five acres, this does not mean that in order to keep a right account with the land you must return an equal tonnage of fertilizer. We have rain and snow for nothing; but the skies do not drop potash, nitrogen, or phosphoric acid, or humus. These the fruit-grower must supply in addition to whatsoever potash, nitrogen, and phosphoric acid may fall to the ground as leaf,--for dropping foliage contains some potash, nitrogen, and phosphoric acid,-as much of these ingredients as are needed.

In practical fruit-farming, while undoubtedly the laws of chemical action work precisely as in the university, or the government laboratory, or at the experimental farm, yet not every acre of cherries is equivalent to every other acre in the country. Trees vary in size, productivity, number per acre, vigor, and so on in many details. But we know, as a fair deduction from our own experience, and from the record of the larger experience of others, that to avoid cropping the land we must feed it, not starve it; we must never take more from it 


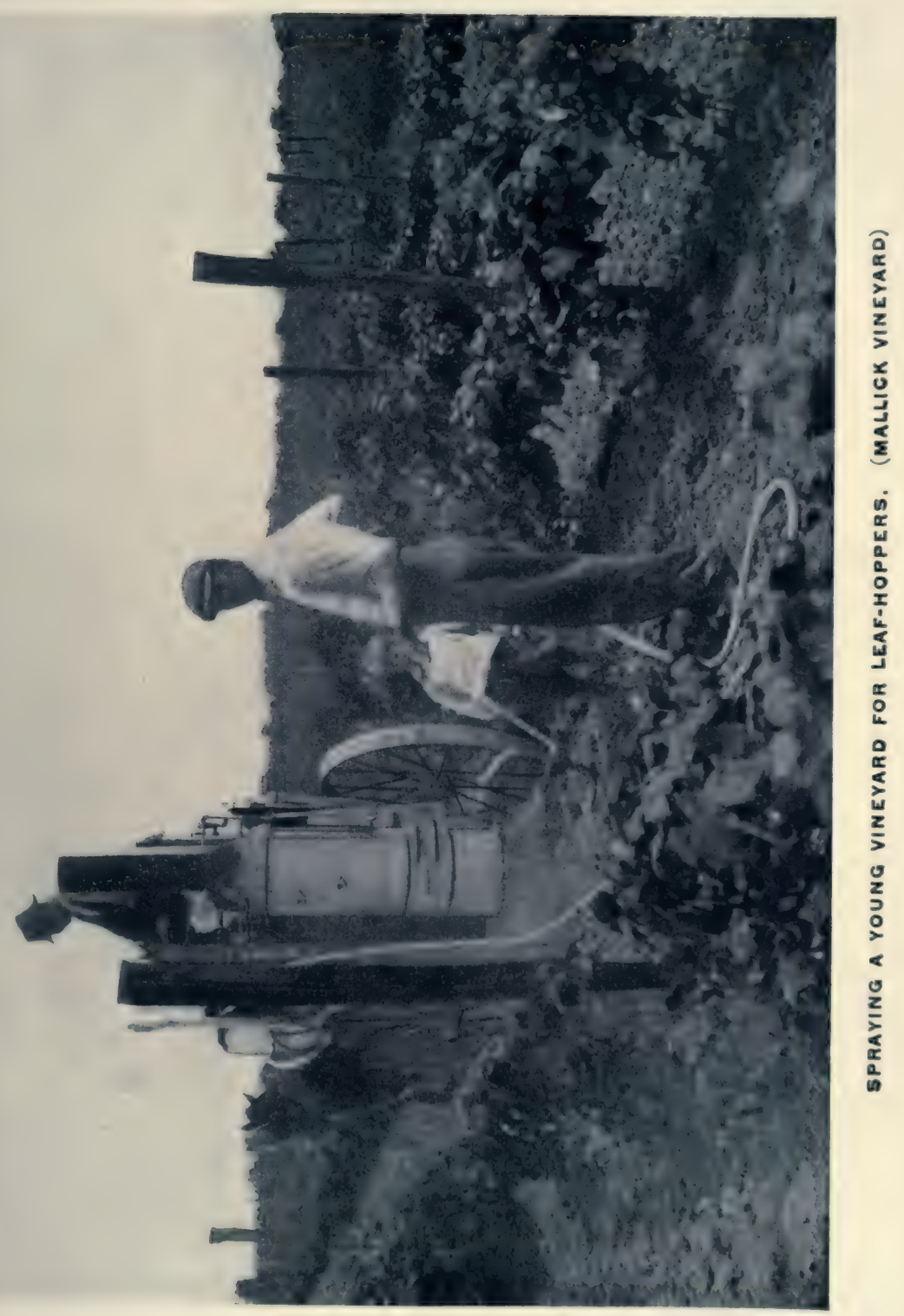



than we give to it. In other words, we must keep it up to a working strength, with a surplus of resource ever on hand. ${ }^{\mathrm{r}}$

It is entirely practicable for the fruit-grower, by a comparison of commercial fertilizers, to determine those most economical for his purposes. Because a fertilizer is cheap by the ton, as for example Kainit, it may not be so cheap as a more expensive kind which contains a larger proportion of an ingredient sought. Kainit is not so valuable as a potash food, as any farm manure. A ton of muriate of potash is as valuable, for potash, as four tons of Kainit. Common salt has many virtues on the fruit-farm, and is used by some vineyardists as a fertilizer. Experience does not support their claim of its value as a plant-food. Farm manure is worth more than any known commercial fertilizer

× The Amounts of Fertilizer Ingredients-Potash, Phosphoric Acid, Nitrogen-Contained in the Crop from One Acre of Land:

\begin{tabular}{|c|c|c|c|c|c|}
\hline Crop & Yield & Straw, etc & Potash & $\begin{array}{l}\text { Phos- } \\
\text { phoric } \\
\text { Acid }\end{array}$ & Nitrogen \\
\hline $\begin{array}{l}\text { Apples } \\
\text { Grapes } \\
\text { Pears } \\
\text { Plums } \\
\text { Potatoes } \\
\text { Tobacco } \\
\text { Turnips } \\
\text { Wheat } \\
\text { Clover, crimson } \\
\text { Onions } \\
\text { Tomatoes } \\
\text { Corn } \\
\text { Beans }\end{array}$ & $\begin{array}{c}15 \mathrm{~T} . \\
2 \% \\
16 \% \\
8 \% \\
200 \mathrm{bus} . \\
1600 \mathrm{lbs} . \\
700 \mathrm{bus} . \\
35 " \\
45,000 \mathrm{lbs} . \\
10 \mathrm{~T} . \\
70 \mathrm{bus} . \\
30 \mathrm{~T} .\end{array}$ & $\begin{array}{l}7000 \mathrm{lbs} . \\
\text { I } 500 " . \\
\text { I } 400 \text { " } \\
5 \text { T. } \\
3000 \mathrm{lbs} . \\
\text { I5 T. }\end{array}$ & 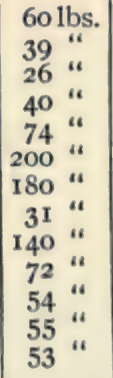 & 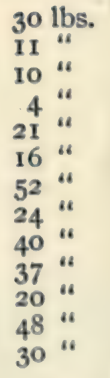 & 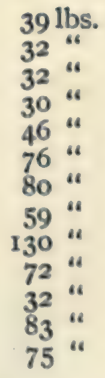 \\
\hline
\end{tabular}


for nitrogen or for phosphoric acid. By comparing the percentages of nitrogen, ammonia, potash, and phosphoric acid, of different fertilizers, together with a comparison of their prices by the ton, the fruit-grower may readily determine which kind is most economical for him to use. There is no need of rule of thumb here: the data are chemically known and definitely worked out. Commercial fertilizers have a tendency to "burn" the land, unless it contains sufficient humus to mingle with them in their solution. Burnt land has the hard, barren, dry look familiar to all fruitgrowers.

No man can successfully run a fruit-farm by mere book-knowledge. Experience, actual contact with the problems of horticulture, must be the basis of success; but the data of the business are better established and are more available to-day than ever before. The Department of Agriculture at Washington, and every Experimental Station, and most of the States now support such, issue valuable bulletins and reports, special studies and results of all sorts of investigations. These documents may be had usually for the asking. The works of Burbank are now being made available and Professor Bailey's have long been classic. ${ }^{3}$

But the most impressive facts in fruit-farming are the hard facts of our own experience. One

The reader is specially urged to utilize L. H. Bailey's The Principles of Fruit-Growing, as well as other volumes of The Rural Science Series, edited by him; published by The Macmillan Company, New York City. 
primary fact is that land must be fed, if fruit is to be raised, - and fed generously. In the Lake Shore Valley, a natural fruit-belt, the land is badly fed. Cropping is the custom. Despite this abuse of the land, crops are heavy and profitable. Proper feeding of the land would greatly increase crops; increase profits, and in no important degree increase labor. An acre of land that produces five hundred dollars gross or, as oftentimes, net, in the fruit Valley, is entitled to a full meal. If it feeds you, you should feed it. We farm in the soil, not in a book. Were the young fruit-grower to depend upon the book alone, he might think that he had only light farming to do; that with a fertilizer factory, a contract with a commission-house, and an auto he would wind the machinery of his farm and simply stand by, in dress-suit and kid gloves, to take in the profits. He like all others must follow the farming experience of the ages. The world has been very slow to learn the art of fruitfarming. The grand rule in farming is to accumulate humus in the soil, first, last, and all the time, and to keep circulation of the moisture and gases within the soil ever active. Plainly, the fruitgrower is a soil-maker. He cannot change climate; he cannot change the habits of the plant; he cannot change the chemical laboratory beneath his feet; he cannot change the food of the plant and have any plant left to feed. All he can do is to align himself strictly with Nature. The wind moves the ship, but whether to port or to wreck depends upon the 
sailors. Nature produces plant and fruit, each after its kind, but whether wild or cultivated depends upon the fruit-grower working through the soil. Having selected in the climatic belt the site for your fruit-farm; having selected your fruit-stock, the varieties you purpose raising; having made your soil, learned its character, qualities, strength, and weakness; knowing what your plants need and how to supply the need, your fruit-farm is an organism functioned for action and service: a machine to be run.

More than two thousand years ago, Cato, writing on farm-management, asks: "What is the first principle of good agriculture? To plow well. What is the second? To plow again; and the third is to manure." Translated into the experience of our race, since man first ran a crooked stick over the surface of the ground and scratched the soil in cultivation, the old Roman's counsel is: "Feed your land and cultivate your soil." 


\section{VII}

THE FRUIT-FARM AND THE YOUNG FOLKS

IT is a common saying among parents: "We want the children to have something when we are gone; we began with nothing and know how hard life is"; and so they save for their children. But what of the children?

The master built a ship for his children, but they did not like the sea, neither could they sail a ship, nor would they learn. A man built a fruit-farm for his children, but they did not like fruit-farms, could not run one, nor would they learn. There are children who like neither sea nor land. Yet there are many farmers and sailors,-but sailors on the sea and fruit-growers on the land.

No parent, even the wisest, can account for the tastes of his child. The mother explains that perversity is inherited on the father's side; the father, on the mother's side; aunts, uncles, cousins, are cited. Nor can the wisest child explain the tastes of his parents, for it is a wise son that knows his own father. After all explanations have been made, there remains between parents and children a great gulf fixed, which cannot be bridged by the 
fruit-farm. What will become of it? What of the children? Of the parents? "Each after his kind."

There is no fruit-farm poor or good but thinking makes it so. To be a fruit-farmer, one must think fruit-farming, for as a man thinks so is he. Few children think as their parents; few parents, as their children. In America there are many fruitfarms, but few fruit-farms occupied by the third generation. In these days when statistics and diagrams are devised to make knowledge plain and conclusive, the diagram of the vocation of a family in successive generations resembles a tornado record, the line of movement marking leaps and bounds, changes and variations and startling extremes. Even in Europe, that imaginary land of fixed, if not of steady habits, continuity of calling in successive generations of the family is rare. There is a famous Zurich family of mathematicians, and a famous Geneva family of botanists: son, grandson, and great-grandson, each eminent, who have been working, generation after generation, in the same field of science. Rare as are such families in the old world, and quite unknown in the new, they embody and represent the true use of leisure, - the activity of accumulated experience. I know few fruit-farms owned and conducted by descendants of the original settler. Shall I venture to compare generations of farmers in America with generations of great mathematicians or botanists in Europe? Fruit-farming 


\section{The Fruit-Farm and the Young Folks 213}

is a branch of applied botany, as Luther Burbank has made plain. So too is it applied chemistry. The significance, if any may be drawn from comparisons among vocations, is of continuity of activity in the same family. Certainly it would be easy to demonstrate in any valley that such continuity makes for wealth, influence, public order, high character, and the general welfare. It would be highly interesting were some economist of practical tendencies to examine into the horticultural interests of our country and bring into common knowledge the effects of continuity of ownership of land, of mastery of its uses, and of contribution to the general welfare of the community.

In most valleys change is the law: new owners, the flotsam and jetsam of cultivation, the extremes of neglect, spasmodic care, hope, and disappointment. Three removals are as bad as a fire, says Poor Richard. Usually it is the remover rather than the farm that suffers. The son cannot see the world through his father's eyes. To the young, the call of the world is as the voices of the Sirens. Youth likes or dislikes and chooses; age chooses on the margin of gain or loss, or safety. To the boy, it is ever something better beyond. Yet a trifle may deflect him from one career to another: missing a train; meeting a stranger; a chance acquaintance, a streak of sunshine, or a blinding snowstorm. Few are the men who are what they are because of deliberate preparation and 
choice. The younger Mill's life was prescribed for him, rigidly, by his father, yet the younger Mill is not measured as a wholly normal man.

The tree drops its seeds and none can tell which shall grow and which shall not. It is the seed in the right environment that becomes the tree. For the visible forest innumerable seeds perished by the way. The planet on which we live is not large enough to grow to maturity all the seeds that fall to the ground. One pair of rats, unchecked, in a few years, it is said, would overrun the globe. Nature maintains the balance of life by a system of survivals, - which we are wont to call evolution. Nor is man exempt from the operation of the law. It is this law which is recognized, quite unconsciously, when the old folks say: "We want to leave something for the children." What is really meant is that the parents want their children to live, to survive, to perpetuate the stock. The dominant instinct of man, like the dominant force in the plant, is to perpetuate each after its kind. To be father of a line of kings was Macbeth's heart's desire. Napoleon yearned to found a dynasty; Sir Walter Scott enslaved his genius and worked himself into senility to establish a family. Alexander, Cæsar, Napoleon left each a son, who each came to an untimely end and dissipated an imperial dream. There is not now living a direct male descendant of any one of the world's most eminent men down to the time of Charles Darwin. Who to-day has the blood of Plato? Aristotle? 


\section{The Fruit-Farm and the Young Folks 215}

Cervantes? Shakespeare? Newton? Washington? And the list may be extended through the ages.

The trees of to-day are sprung from the trees of ages past-that is, the trees of the wild. When we turn to the trees of cultivation we find not one variety which comes to us unchanged from the time of the Cæsars, or even of Shakespeare. Parton, in his life of Franklin, written in the middle of the nineteenth century, remarking on discoveries, inventions, and improvements which would most interest Franklin, mentions "the improved strawberry." Shakespeare mentions strawberries; they were a common fruit in the days of Horace; Lucullus, before him, served them frozen at his feasts. Doubtless as a little boy Adam went strawberrying, but he did not pick Brandywines, Parkers, Earles, or Marshalls. Indeed, I suspect that the Garden of Eden, in his day, produced small, sweet, wild strawberries, like those that grow under the hedge and among the shading hollyhocks by the arbor. Possibly the original strawberry was only a small, hard, sour bunch of seeds. Forgotten Burbanks have added the luscious, juicy pulp and cast out the seeds. Yet despite all the cataclysms of the ages strawberries were and are. But the survivals we know are not of the Adam variety, but masses of scarlet pulp of our making. Man has made the strawberry, the peach, the apple, the cherry, the prune, the grape, the pear, the plum, the berry which we know. Cross-fertilization and breeding assemble 
dominant qualities and elements. This, too, is a survival. So Nature wins whatever man does.

We want our children to live in comfort, not to say in affluence, and so we labor for them. We make a fruit-farm for them, planting orchards and vineyards. Possibly our family runs to sonsin-law, but we labor on, hoping for the best, and hugging to our hearts the motto, "a rose by any other name will smell as sweet." But whether we have sons or sons-in-law; they have their own ideals. It is the fruit-farm as a commercial article that may interest them,- - not as a living organism, or as a home. We would have our children live in the security of the old homestead; they yearn to live anywhere else; or, possibly, the restless season of life over, one of them-son or son-in-lawtakes the homestead as his portion and settles down to the solution of that common problem, "What shall I do for a living?" If he can discover nothing preferable, he remains on the farm. Is his estimate of its value his estimate of associations or of possible profits? His estimate of its value may be of emotions more justly to be accredited to the world-at-large. He may look upon the whole world as only a large fruit-farm, and this his corner to be his refuge and his home. Have you ever observed a fledgling leave the nest? It seems oblivious of dangers. It flies off boldly and alights in front of the cat, or in a tub of water, or is helplessly enmeshed amidst a stubborn brushheap. If it alights in your hands, it looks at you as 
The Fruit-Farm and the Young Folks 217

if you were a tree, or a stone, or a telephone pole, not casting even the shy glance of fright. So when the young folks start out in life, like fledglings, they act as if any place is a safe refuge and all the world an old friend.

The prodigal son went to a far country: the farther from home, the keener the isolation. Breaking home ties means turning your back on old associations. If you leave home very early-say in infancy,-you are spared the break; it comes later, if at all. We who are parents and have formed associations and know that a bundle of them makes a human life, would secure our estate -be it heritage or not-for our children. We know the value of these associations and would have the young folks know it also. But as the fledgling cannot know where it shall alight when it soars from the edge of the nest, so the young folks cannot know their future when they break the home ties.

The first settlers in the American wild desired, as earnestly as do the owners to-day, to leave their children valuable land as safest protection against the day of want. Yet, turning over the pages of the Book of the Fruit Valleys, we read of immigration and emigration, east, west, and south, to pastures new, to callings and vocations more to the liking than fruit-farming. So too read the pages of the book of any community in America. We are a restless, a migratory people, who, in the short space of a hundred years have overspread the continent, making settlements, organizing territories, 
founding States. Upwards of thirty millions of people comprise this moving mass. Europe, Asia, Africa, have sent millions. Their descendants, called Americans, have swelled the stream, and every year it is further enlarged by more than a million who arrive from Europe alone. It follows that results long ago foretold are occurring. The desirable lands have been taken up and no longer can a farm be had for the asking. Very rapidly, and notably since the Civil War, America approaches the condition of Europe: scarcity of land; increase of population; decrease of production of food-stuff; cost of living rising; the traditional ease of life in America vanishing. Never again can the old-fashioned simplicity of colonial life prevail. A hundred years in America have wrought changes comparable to those of centuries in Europe. The trend on both continents to-day is the same: toward class distinctions, discriminations, complexity of industrial conditions, elaboration of innumerable wants, and diminution of means and opportunities to satisfy them. In brief, the machinery of life seems ever becoming more complicated, and we are thinking, as it were by compulsion, more of the machinery and the machine, and less of the spirit who inhabits and moves them. This means the ever sharper realization of the discomforts of life, real or imaginary, and the greater risk of experiencing discomfort than comfort.

Parents now, perhaps as never before, are yearn- 
The Fruit-Farm and the Young Folks 219

ing to leave something to their children that they may escape discomforts and pain, the enforced self-denials such as parents themselves have experienced. We would have our children journey along the primrose rather than the thorny path of life. In this yearning there is nothing new; it is true of all peoples in all ages; it is the touch of Nature that makes us all akin. But the antiquity of the touch does not diminish its humanity. It is renewed in every parent and yet to him and her seems as novel as a discovery. It may be questioned whether, as land and all activities connected with it become more and more commercial, the chance of its successive use by generations of the same family does not diminish. The rural constantly approaches the social and economic urban state, though never seemingly actually reaching it.

In New York, Philadelphia, Los Angeles, Atlanta, Boston, Chicago, St. Louis, Minneapolis, in any of the thousands of our cities and towns, the personnel of what is called "the business section" changes twice each generation. Sons and grandsons do not succeed to the business of their fathers, much less in it. The business of a great city as well as of a little town is done ever by new men. "Old established houses" are new. For many years in the Valley the sign over a wellknown store read: "B. C. Town." A drummer who sold the firm sugar was wont to tell his other customers that he did business with the oldest town in the world. The date on the door may be 
old, but usually the business within has changed hands repeatedly. So too in the country: "This is the same fruit-farm, but the A-y-1-s no longer own it; the children did not care for fruit-farming; the girls got married; the boys went to Chicago.'

In city or country the boys do not follow the vocations of the fathers; farm-boys become bankers; bankers' sons become fruit-farmers. The succession is as uncertain in the city as in the country. In affairs of state we call it a revolution, when the Bourbons cut off the young King of Rome from the throne of Napoleon, or the Prince Imperial, missing his seat in the saddle in Africa, is cut off by a savage spear, and the Republic goes on. There are like vicissitudes in private life; every station runs the risk of exile. The parents would prevent this but the young folks seemingly covet it. The farmer's son hates the farm; the banker's son hates the bank; the doctor's son hates the very odor of his father's office. The mere mention of orchard or vineyard brings up a picture in the farmboy's mind of February fingers fumbling to trim interminable rows of interminable vines; of ladders of weary weight and height; of endless bushels of apples swaying out of reach in a high wind, and never a dollar for the boy himself. The boy was thinking of how much pleasure that dollar would give him; his father was thinking of how many apples he was giving for a dollar, and quite forgot the boy. What if the father had invested the dollar in the boy by giving him a slight share in 
The Fruit-Farm and the Young Folks 22I

the apples! Would the ladder seem so heavy or the apples so high, or the rungs so hard, or the wind so piercing? Or had the father invested a few bunches of grapes in the boy, would the rows seem so long or the vines so many, or February fingers so numb and cold? The father trims grapes all day long and never a word about cold fingers. The prospective profit in grapes keeps him warm. Hopelessness is always cold. Age nor sex is exempt. Here is the mystery of association.

The father must needs make possible the right sort of associations. Every man pursues as best he can his own substantial happiness; the boy among the apple boughs sees his happiness in the apples, if they are his apples. Otherwise they may as well belong to the neighbors. It is a nice question on every fruit-farm, -as to the young folks,-whether the farm is really theirs or the neighbor's. If the boy picks apples for a neighbor he is really picking his own dollars from the apple tree; on his father's farm he picks his father's apples for his father. At least this is the boy's version of the facts in fruit-farming.

Shall the father then hire his own boy to pick his own apples? It is not hiring, when the boy is interested in picking apples. The family is the ideal community and the boy has his part in its communal work. But nowadays even the children "strike." Few seem willing to work for another, children for parents, or parents for children. Yet, in the Fruit Valley all the children have not 
"struck," nor all the parents ceased to provide for their children. At least children under fifteen still stick to the old folks, but the youth of eighteen or twenty, working on the fruit-farm for "the old folks," is a rare bird in the landscape. Whether there be one or several boys, the fruit-grower usually runs his plantation by hired help. Not one of the boys is at home. The bank, the postoffice, the grocery, the factory, the railroad, the office, not the fruit-farm, holds them. But the old folks still live on "the place," and the boys occasionally come home and look upon the farm as a distant asset. His business bringing him through the ancestral Valley, the boy "stops off" "over a train" and is a guest at the old home. $\mathrm{He}$ is treated as a visitor and discovers what a quiet, comfortable, pretty spot is the old farm. He sees it at a different angle from that when he picked apples from tossing boughs. He was not so well treated when he was a boy on the farm. Perhaps, had he been treated as well as the passing guest, he would not have left the farm. He did not know it was so comfortable. Bank, office, factory, seems for the moment a prison-house, especially if this visit be in summer. And he turns from the old home back to his prison-house with a sigh. If they had treated him as well twenty years ago, would he have left the fruit-farm in disgust? The glamor of office-life, clerical work, railroading, practicing medicine,-whatever his vocation,-has faded. Work is work whatever its name and wherever 


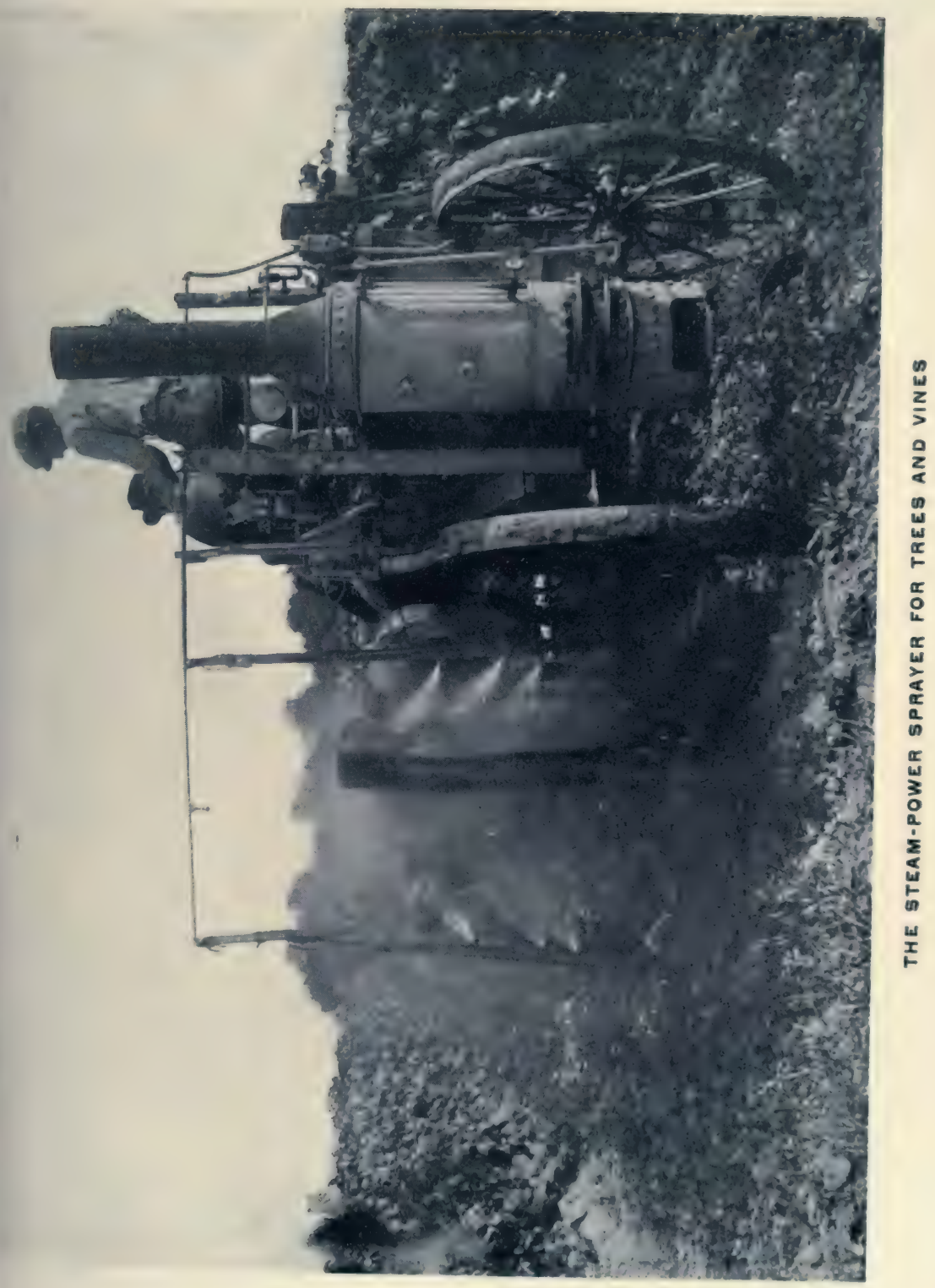



The Fruit-Farm and the Young Folks 223

found, on farm or in factory. As now his eye roams up and down his native heath, to the hills, over the lake, across the grand sweep of orchards and vineyards, comfortable homes among the trees, the quiet of prosperity, he is saying: "What more is there than this, but I did not know; I could not know; my father never let me know. Hard work, early and late; mud, and storm, and cold, and never a penny to call my own. That is my memory of the old farm." Yet when this man was born, his mother said to his father: "Now, Samuel, we want him to have something when we are gone; you and I began with nothing, and we know how hard life is"; and so they saved for him, and in their zeal for saving they forgot him entirely and thought only of saving. They saved the money and lost the boy.

"For the life is more than meat and the body than raiment." Are the parents saving life or old clothes? Did the mother say at her boy's birth: 'You, son John, are born, delicious torment as you are, and you are born for the sole purpose of accumulating \$17,314.19; and you, Maria,-I forgot to tell you, that you are to marry $\$$ I 9,4 I3.7 I, and mind you, both of you, not a penny less. So take notice. Now leave the room and let me sleep; but, Samuel, don't forget to put on a kettle of hot water.' Was it not the thrifty mother of George II., "snuffy old drone from the German hive," who, as Thackeray tells us, was ever saying to him, "George, be a king!"? And he played king till the curtain was rung down. What fruit-grower says 
to his boy: "You were not born with a silver spoon in your mouth but to get silver spoons." The orchards and vineyards teem with prosperity; many a fruit-farm grows a fine quality of grapes and a poor quality of boys. In laying out the farm, in making the soil, the farmer should plant boys as carefully as he plants grapes or peaches. Each after its kind. One of the contradictions in country life, real country life, not city-country life, is the splendid cherry trees, the strong horses, the multiple-laying hens, the tons of grapes, and the ordinary, not to say extraordinary, boys who turn out less than a ton to the acre, which itself turns out five. "The fathers have eaten sour grapes and the children's teeth are set on edge." "No grapes for me, thank you!" says the grape-grower's boy; "I'll take (accept!) a clerkship in a grocery." "What!" you exclaim, "and grapes at fifty dollars a ton and live at home, and the grocery business so overdone!" You think that you would take the purple vineyard and let somebody else keep store. But your father had a store-not a vineyard.

The fruit-farm produced fruit, not boys; they were a mere bye-product; handy, if workers, but often much in the way. Expensive as they get older. Good as anybody's boys, but they will never make farmers. And so the years pass; the old folks become more economical, saving the more eagerly that the children may have something to begin life with. When the children think themselves ready to begin life for themselves, or 
do begin it, ready or unready, - the old folks begin talking of saving for the grandchildren. Doubtless Methuselah, in the last few years of his life, began saving for his grandchildren of the thirtythird generation. In every valley there are many like Methuselah, only younger and possibly more economical. It might seem there that posterity stands in a fair way of being prosperous, - as the world goes. These orchards and vineyards, sweeping from the lake to the hills, who shall inherit them? Yet, to-day, as for untold ages, and notably for a century and a half past, the only permanent resident of the Valley is the land. The people emigrate. A few ancient families remain on the old site their fathers chose, four generations ago, prosperous fruit-growers, than whom there are no better. It might seem that prosperity would prove contagious, but many who have eye̊s see not. For more than a hundred years young folks have been born in the Valley with peculiar eyes that see things far away but are blind to the world that spreads about their feet. Many a farmer who saw the pot of gold at the end of the rainbow could not see a living on his own farm. Even fruit-farming requires the seeing eye. No man is larger than his vision. The dream of the old folks is that the young folks shall prosper, and the young folks have dreams of riches. They are daily bred to a creed of things. They will begin life where the old folks left off: riches are the principal thing, therefore get riches. But in the struggle 
for riches both old and young may miss the mark. The prize falls to another. Raiment and meat become more than life. The folks exist for the fruit-farm, not the farm for the folks.

Various crops are raised in the Fruit Valley: grapes, apples, berries, peaches, prunes, cherries, plums of all colors, tomatoes, corn, melons, and people. Thousands of tons of grapes, cherries, berries; soil at eight hundred dollars an acre, and more; winters in Florida, California, Cairo; automobiles; journeys to the center of the earth; buildings shining with architecture and new paint; railroads, trolleys, cities, towns, villages, lawyers, doctors, newspapers, - the endless list of things called America. But the heaviest crop of all is expectation: "To-morrow! To-morrow!" Then shall orchards and vineyards and fields run more to the acre than "Yesterday!" or "To-day!" Indeed, To-day is only a rabbit-run to To-morrow. Gathering our crop To-morrow, we starve To-day; and Shakespeare could not be first to discover that "all our yesterdays have lighted man the way to dusty death."

The fruit-farmer is saving for to-morrow, forgetting to-day. The young folks live to-day. Forgotten by the old folks they live in their own world of fancy, immeasurably remote from the fruitfarm. They live where fancy breeds. Is it in vineyard or orchard? Or in the city? On the coast? In the office? The factory? Is it anywhere save on the fruit-farm? Anywhere save in 
The Fruit-Farm and the Young Folks 227

the Valley? "Yes," dreams the boy without interest in vine or tree, "it is anywhere but here!"

Here is another chapter of the old, old story: breaking home ties; leaving the nest; seeking pastures new; going out into the world. Animals and plants have their native regions clearly defined by climate. The spice trees fruit only in the tropics; apples do not grow at the equator. We mark off the zones by the plants which grow within them and the wild beasts which inhabit them. Climate makes prisoners of all living things. Man alone seems the exception in that he carries his climate with him. To him it is food and clothing and so he penetrates the corners of the earth and makes most of it his habitation, and, save as moved by overpowering curiosity, or thirst for fame that comes from triumph over perils of heat at the equator, or of cold at the pole, he migrates always along the line of climate in which he was born and bred. This is the long story of the movements of nations and of individuals. The New West is the Old East removed a little nearer the setting sun. Even restless youth obeys the great law of migration. He goes whither he can stand the climate; it is his master and the racial instinct tells him this. He will not contend against perpetual frost or burning heat. He seeks ever to live under familiar skies. Who of us feels at home under strange constellations? Who of us knows what it is to be far from home and see strange stars breaking upon our vision? Restless as youth may be, it knows 
instinctively when it reaches a land in which it cannot live.

It is instinctive in the animal world to migrate for posterity. Most birds are migratory, journeying far to nest and rear their young. All the birds in the Fruit Valley come thither every spring from the South, even the far South, Central America, Brazil, and the islands of the tropic sea, and having reared their young, return to the South in the autumn. It is one of the amazing sights of Nature,the vast annual migration of the birds. It marks the power of instinct common to the animal world, - the instinct for the procreation and persistence of life. Birds have their nesting-time and they straightway seek their brooding grounds. Some birds are not controlled by this impulse; they never leave the region of their nativity.

I remember a farmer who not only lived for his boys but with them. When the nest-building time came for one of them, he joined in helping by building as a wedding-gift a pretty house, and giving with it a handsome portion of the old farm. There the nest-builders live to this day-the third generation on the old farm. Had the father never read the signs aright, his boys - and he treated all alike-would have flown to pastures new, leaving the old folks forever.

After the children are born, the parents dream dreams and see visions; there is more and more the backward look; and as the children grow into youth they too have visions, but their look is forward. 
The Fruit-Farm and the Young Folks 229

To-day is overlooked; all is to-morrow. When nesting-time comes for the young folks they find themselves in an uncongenial world, and migration is escape. Acres of fruit, thousands of trees, but no room for the new nest on the fruit-farm. So the young people of the Fruit Valley fly to other valleys, and there build up associations for themselves.

That supreme dictator of every fruit valley, climate, has never changed his methods or his might. Storm and sunshine, heat and cold, frost and snow, the gorgeous sunrises and yet more gorgeous sunsets, the sweep of air from the hills to the lake, from the lake to the hills, and up and down the Valley are to-day as they ever have been. All generations of men are prisoners of its climate.

Then there are two that remain, soil and the man. Changeable or unchangeable? New men, new minds. Each generation is itself, unique, distinct, functioned unto its own day. The pioneer was not the child of our to-morrow, nor can he of the next generation be the pioneer. Each after its kind is the law. The man with the ax building the log-cabin cannot be the man with the checkbook building the country house.

What of the soil? It seems but yesterday that I cleared away the primeval woods; cutting down giant chestnuts and walnuts; trimming the logs, hauling them to the mill for lumber. All the rest burned-limbs, branches, underbrush, decaying and falling trees, and the great stumps which first 
were wrenched from the earth by explosives. The ashes I scattered about and plowed the new land and subdued it by cultivation. What a wonderful crop that virgin year! Then the vines were set and the primeval forest of yesterday became the dark, dank, glossy vineyard bearing many tons of purple grapes. Twenty years have passed. Now it is half the tonnage. Have I robbed the soil? Tons of plant-food have I spread upon it; carefully has it been tended, yet that virgin gift of the purple grapes can never be made again. Fifty years hence what shall the harvest be? Is the soil depleting? The cornfields of the pioneers became the vineyards of to-day. Those that remain no longer bear their first weight of purple fruit. The vineyards were torn away and orchards were planted in their stead. No longer do the trees bear their youthful weight of fruit, or withstand the onslaught of their enemies, fungi and insects; as the years pass, these enemies multiply. And the history of the Valley is doubtless like that of other valleys.

You will hear it said in the Fruit Valley: "My grandfather could raise peaches without spraying the trees"; but the enemies of those pioneer trees are forgotten. We know that had the Valley then been filled with peaches, it was so far from the world they could not have reached it before they spoiled. Sufficient unto each generation are the enemies of its flocks and herds, its orchards and vineyards. Yet, despite the fall in production as time passes, 
The Fruit-Farm and the Young Folks 23I

the Valley to-day produces a greater tonnage of fruit, and finer fruit of its kind, than is produced on any equal area in Europe.

Is the soil failing? Are diseases of fruit, insect, and fungous enemies increasing as the years pass? It appears not. We have cut away the original forest; we have changed the face of Nature; we have destroyed the plants, trees, shrubs, flowers, weeds on which these our enemies feed in the wild; hence they are driven to our orchards and vineyards for a livelihood. There is nothing new under the sun even among insect pests and fungi; we are reaping the harvest our civilization has sown. And as the land is more and more deforested, as the wild is more and more subjected to man, we may expect discovery of new insect pests and new fungi. The next generation must deal with these evils, for surely it will be confronted by them. More people, better markets, higher prices,- - this is the outlook for the country at large. There remain the three dimensions of fruit-culture: climate, soil, and the man. Climate is unchangeable; the soil and the man remain. Man makes the soil. The keeping of all the valleys is in his hands,- the next generation and all that shall come hereafter. "Remember, friends, to-morrow is another day," runs the ancient Arabian proverb. That other day may mean in truth another Valley than this we see, for the man of to-morrow is not the man of to-day.

We are come at last to the supreme interest of 
the next generation - the care of the soil. It must ever remain the test of all fruit-farming. Soilcropping means the extinction of our race, and the steady depletion of the soil means the ultimate conclusion of the history of all fruit valleys. Enormously profitable fruit crops are now raised in many parts of America. The longer the land is tilled, too often the soil becomes thinner and poorer. The history of the production of wheat and corn is of this depletion. Not only has the production of corn and wheat removed to new land, westward, ever westward, but all along the line of removals production has fallen. From New York, Pennsylvania, Ohio, Indiana, Illinois, Michigan, Iowa, Wisconsin, Minnesota, the Dakotas, California, Manitoba, the great wheat valleys of Canada and British America,-whither next? The wheat strength of the older States exhausted; of the Middle West; of the old Northwest; of Minnesota and the Dakotas; of Canada; a long, long line of diminishing wheat-returns. And the day not far distant when America must import wheat. There are no more new lands in America. Will some variety of wheat be originated that will produce abundantly on lands hitherto unavailable for wheat, as the vast reaches of aridity, of mountain steeps in the West? All this means that farming in America has passed, like my virgin vineyard, into an older stage of less production and is becoming like the farming in old countries. It means that intensive farming must supplant extensive. If I 
raise eight tons of grapes again on these acres of vineyard, I must make the soil as I found it twenty years ago. There are no more virgin soils east of the Mississippi, and fewer each year west of it. We are confronted by a problem of problems: How to raise food of all kinds on a fixed acreage and for an ever-increasing population?

Everywhere in America, the effect of this tremendous "pull" on the land by orchards and vineyards is plain. The best fruit-farms, by following intensive cultivation, hold to their old records and even surpass them, but hundreds of farms are rapidly losing their strength through under-feeding and over-cropping. Unquestionably the next generation, and generations to come, will receive a larger acreage of such worn lands, and it is their problem of problems to bring the soil back to, or forward to, or up to, its highest pitch of fertility. The old methods of fertilization, even of cultivation, even those practiced half a century ago are abandoned. Then many a valley was a vast stock farm, and barnyard manure could be had sufficient to keep the land fairly with humus. But we cannot longer build humus into the soil in this day. As the best fruit-growers interpret conditions, there was not, even fifty years ago, enough fertilizer used to keep the land in best order to feed plants. We feed the land better than did our predecessors. Consider one example. There are upwards of ten thousand tons of grapes raised each year in the Valley, and this enormous 
output on a little less than four and one-half million vines. In Chautauqua, the adjoining county, the yearly product is sixty-six thousand tons, on some sixteen million vines. Besides this yield of grapes the Valley gives orchard fruits, apples, peaches, pears, prunes, plums, cherries, quinces, and raspberries, strawberries, logan berries, nuts, and much garden truck. The federal census prints elaborate tables, long columns of figures, and leaves values quite to the imagination. Of interest to us is that the average yield of each grapevine in the Valley is a little less than seven pounds. Now the yield to the vine depends upon many conditions: the species or stock; the site; the trimming, and the cultivation; but essentially it depends upon the soil. The land that will grow the vine will grow grapes. A basket, weighing eight pounds, the usual size, to the vine, means six hundred baskets to the acre, that is a little over two tons. On virgin soil, or on soil kept in high fertility, eight tons are raised. This is a maximum and an unusual yield. There are hundreds of acres which do not average half a basket to the vine, that is, one ton to the acre. These are the neglected, the worn-out vineyards. All this means soil depletion. During the last fifteen years orchard fruits have come into fashion and fruit-growers have turned from viticulture to the raising of tree fruitscherries, prunes, peaches. This means that the soil of an old vineyard may be virgin soil for a new orchard. But this virginity will pass unless the 


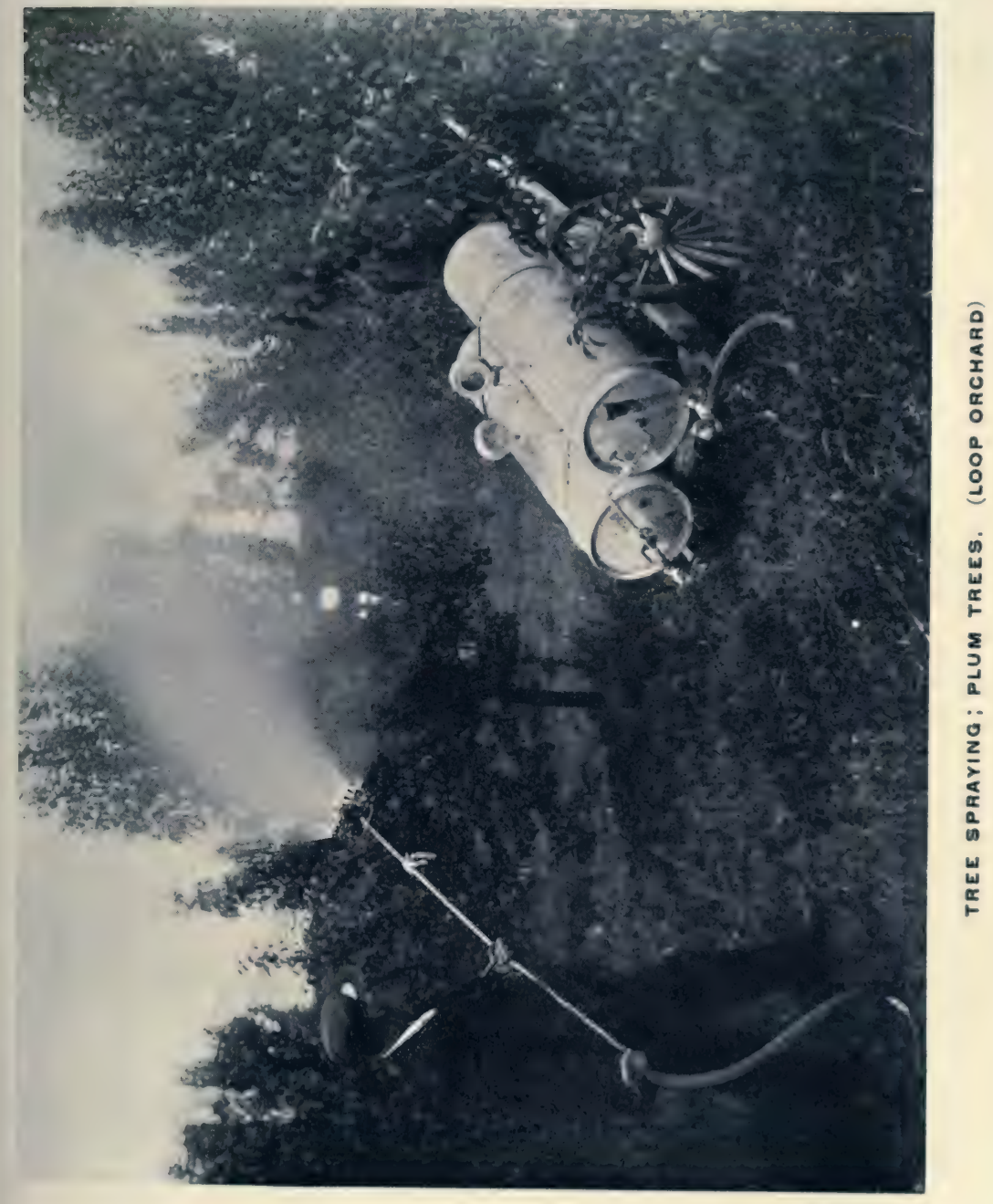





\section{The Fruit-Farm and the Young Folks 235}

soil is well sustained for orchard fruits. If an acre of land will produce one hundred and fifty dollars in grapes, or five hundred dollars in cherries or peaches or other crops, it feeds a voracious crop and must itself be fed accordingly.

Soil making, which is soil-feeding, is the principal problem which confronts the next generation. It cannot be set aside. Just how to solve it, each generation presumes to know best. In our day the solution is largely left to the commercial fertilizer factories. This means an attempt at scientific farming. The Experimental Stations and Agricultural Schools, as well as the Institutes of Chemical Industrial Research, are working at the problem. The rule of thumb in horticulture is outworn; yet intensive horticulture has made slight progress in America. Men cling to old methods because it is easier to cling than to think. No man has mastered the art and mystery of fruit-farming; he who knows them is of the next generation. Therefore it is undoubtedly true that the hardest problem which the next generation must solve, or help solve, or at least attempt to solve, is the problem of soil-depletion. Land is limited; population, unlimited. Subsistence depends upon the use of the land. It must feed an ever-increasing multitude. This means higher cost of living; higher prices for food; a better market as the fruitfarmer would say. The number of bushels of cherries or of baskets of grapes may decrease but the number of people demanding fruit increases. The 
catalogue of prices for fruit is written not alone by the depletion of the soil but also by the increasing demand for fruit. Land is static; there are ever more mouths to fill. The market is open to the highest possible yield of fruit, and the yield per acre may by intensive cultivation be increased five hundred per cent., even more. The price falls, if ever, not by reason of tonnage on old lands but by temporary invasion of the products of new. This ceasing, as practically it has ceased in America, prices become firm and tend to rise. The problem then is to raise the fruit. There is ample market for the largest possible production. The increase of population consumes all the increase in tonnage and demands more. And rich, welltended soil means perfect fruit in abundance.

America now is far less fruitful than were its every farm maintained at the level of highest possible production with present knowledge. Fruitfarming in America can as yet be said hardly to have made a beginning. Profitable as is this vocation, its possibilities are as yet quite undreamed of. All now done is but a hint of what might be done, of what shall be done by the next generation. Posterity will not neglect to move along the easiest lines. As the struggle for existence becomes more and more severe in America; as competition compels men to exploit the possible vocations, fruit-raising will become more and more a technical occupation. Necessity as well as opportunity will bring about a higher type and order of fruit-growing in this 
Valley as in other valleys. To this use the owner of to-day hands on his land to the next generation.

And what shall this generation and its successors do with the Fruit-Farm? Of course they must use it and pass the use along to others. It is to the man we come at last. He is the soil as he is the thinker. The harvest is his thinking. These grapes, peaches, cherries, plums, prunes, berries - Romeo's raspberries - are his thoughts. The whole matter then is of thinking. Each generation must think peaches if it would raise peaches. Ideas in the soil become plums on the tree; no ideas -no plums.

There are postulates, corollaries, and addenda to the vocation of fruit-farming which the next generation must duly consider. The grower is a Producer; there remain three other factors in the problem,- - the Consumer, the Exchanger, the Laborer. This classification is somewhat rough and conventional, for we know that each factor has functions in common with the others. The next generation of fruit-growers must bear the burdens of government and misgovernment. Immigration has passed the saturation point in America, and the excess is a factor of unknown powers. Certain it is that the individualism of the pioneers cannot distinguish the next generation. Cooperation, combination, convention, association, must henceforth be the supreme quality of determining functions. Public opinion has ceased to be merely local; no one fruit valley can control 
the world at large. It must accept its share of service. It is to be expected that the mere external clothing of the Fruit Valley will change. On fruit-farms of forty years scarcely a vestige remains of varieties first planted. The conspicuous survival is the Concord grape. If one turns to a nursery catalogue of forty years ago, he may read long lists of varieties now unknown, or known by another name. The Fruit Valley is a survival. So too is the fruit-farmer. Even the fences of the grandfathers have disappeared. On the site of the log-cabin stands the country mansion. The springs have dried up and the house is supplied from public reservoirs, or from deep wells whose waters are lifted by wind-mills or engines. The age of ornamentation has begun and the next generation will beautify its estate yet more. Here and there is a plantation on which men, women, and children are taking time to live. Necessity breeds public and private health. But the next generation inherits our nature and we shall be present despite new kinds of peaches and cherries.

Contentment is a rare bird in the land and it lays few eggs and few of its progeny survive. There is a philosophy in discontent, for that way progress lies. Quiescent satisfaction means petrifaction. Wisdom does not die with the fathers nor will it be born exclusively with the next generation. The Fruit Valley is a stage and all its men and women are merely players. Our grandfathers could not know the ecstasy of an automobile,-its skidding, blow- 
The Fruit-Farm and the Young Folks 239

outs, stalling, or "What in the world is the matter now"?-nor can the next generation ever feel the joy of going to church in an ox-sled. Yet the great things of life are not necessarily summed in rapid transit. And the next generation may miss some of these things; it may not be able to see them on account of its Fruit Valley. Face to face with climate and soil and itself, the next generation, fighting for existence like all its forebears, will become in turn the theme of criticism in the mouth of its offspring; and as the day lengthens and the shadows gather, it will cling, like its fathers before, to the experiences of its own life, however bitter, and like all its race will at last find herself a stranger in a strange land. It too will have completed a cycle, for in every Valley the cycle of life is from the unknown to the unknown. 


\section{VIII}

TEN THOUSAND A YEAR

THERE may be inhabitants of the Fruit Valley 1 who are "passing rich at twenty pounds a year"; the common demand is for more. Indeed many aspire to be catalogued among the half million Americans whose yearly income is at least ten thousand dollars. Comparisons grow in the Valley even more vigorously than fruit. Time was when money was a curiosity in the Valley-even no longer ago than when Captain Dobbins and his house-carpenters were building that immortal fleet which bore Perry to victory and made the Northwest American soil. It is no longer a curiosity, but is looked upon as a sign or specimen of what the Valley might produce if it was thoroughly worked. So oftentimes the Valley is spoken of as a gold-mine. The millions that flow into the Valley to-day shrink in the eye of expectancy. Tomorrow,-more. Like the grave,-more, more! Fifty years ago the farmer was passing rich at twelve dollars an acre from his land; to-day, his successor thinks one hundred dollars from an acre a small dividend. There are many rumors. One 
hundred and fifty dollars from an acre of grapes; two hundred from currants; three hundred from raspberries; four hundred from prunes; five hundred from cherries; six hundred from peaches; seven hundred from-yes, that is what I was about to plant. John Law and the Mississippi Bubble could hardly stir the imagination to livelier fancies. And when we can raise grapes, currants, raspberries, gooseberries, prunes, cherries, and peaches on the same acre,-intensive Dalmatian cultivation,why not "passing rich" on twenty-one hundred and fifty dollars an acre, and possibilities for lettuce, turnips, and cabbages between the rows! But shut the eye, and you are a millionaire!

Were every owner of land in the Valley as thoughtful and wise as he is eager for ten thousand a year - and had he land enough - he might realize his hopes. Nor need he own many acres. But he must own ten-thousand-dollar land. Fifty-dollar land will not do it; nor five-hundred dollar land. Ten-thousand-dollar land and no other must be had. And there must be the man. Climate abides; stubborn, friendly, hostile, freakish, helpful, dominant. So we pass climate. But the man is a tenthousand-dollar man; not a thirty-dollar, or any dollar below ten thousand. Like breeds like and no man is greater than himself. And his fruitfarm is his measure. It is easier to see him in his farm than in his clothes, be it at mill or meeting. But his farm blurts out the truth about him. Live weeds keep no secrets. Dead ones tell tales. The 
fruit-farm is evidence on the spot, and he cannot prove an alibi and also claim title to the fruit-farm. He may say what he pleases; his farm speaks for itself is his indisputable confession. We come to the man at last.

And he makes the farm: soil, orchard, vineyard, and the rest. He selects the varieties; trims, tends, harvests, markets. When he counts gain or loss he merely takes an invoice of himself. He may charge losses to the weather or to the wickedness of man, or to the hunger of fungus or insect; he may credit gain to the weather, or to the wishes of man and cultivation; but somehow, as the years pass, it is he himself who divides the account between loss and gain. If he is the gainer there is gain; if the loser, there is loss. Fruit-farming in all valleys is a human invention. Nature cares no more for filberts than for Canada thistles; man prefers the filberts and roots out the thistles in order to grow filberts. $\mathrm{He}$ invents filberts. $\mathrm{He}$ would invent Canada thistles on provocation.

The man who produces ten thousand a year from fifty acres has a secret which he may not be able to impart. Usually it dies with him. His successor, on the same acreage, makes a bee line for bankruptcy. He understood how to do this, but not to raise ten thousand a year. Nor can he be told, or instructed; he is not the man for the job. There is no more familiar sight in the Valley than of a fruit-farm which was. "While Jones was alive, you should have seen that farm; it isn't the same 
farm any more. Russell White knew how. That's all there is to it." This is speech of the Valley. The world knows a fruit-farmer when it sees one. They are not numerous. And the new owner of White's farm is a clever man, too, in his way. A "nice" man, an obliging man, even a pleasanter man, so the Valley says, than was old Jones; but he cannot run a fruit-farm as White did. True, he can run it so that the sheriff wants it so badly as to take it. But that is not considered just the best kind of fruit-farming in the Valley. No it was White himself that made the White fruitfarm. When he died it ceased being a fruit-farm. It became mere trees and vines and took a gallop toward the wild. White transformed it from the wild into a garden. The pendulum always swings to one side or the other, or stops dead at the center. The Valley has many acres which thus swing from wild to garden; from garden to wild. Thus time passes by the horticultural clock. But White was a ten-thousand-dollar man.

There was another man-Neville also born a fruit-grower. He inherited his acres and transformed them from mediocrity into capacity, - he really educated his land till had any Agricultural College in the country been fully awake to its opportunity it would have conferred on him the honorary degree of Master of Fruit-farming. In these days when colleges give degrees for stenography, bookkeeping, and economics, it seems strange that Neville missed recognition, for his genius 
made stenography, bookkeeping, and economics possible for scores of people-at salaries. But there is no accounting for tastes among colleges. I do not doubt that any faculty would have eaten Neville's peaches with relish and asked for more, like Oliver Twist, but as yet the capacity to make a thousand bushels of peaches grow where none grew before is not considered sufficient evidence to merit more from the Faculty than a modest order for peaches. Nevertheless Neville was another ten-thousand-dollar man. $\mathrm{He}$ could not have learned it from his father, or from the neighbors, and he never attended raspberry lectures. $\mathrm{He}$ was born an M. F.

In talking with Neville I never quite secured his secret,-if he had one; yet he never concealed his methods, nor boasted of them. He knew wind and weather, and could anticipate the market closer than any other man in the Valley. He always had something to sell. Somehow his crops never failed. He would never suffer a poor plant to live on his farm. At almost the first symptom of disease he would root it out and replant healthy stock. He had few varieties and somehow managed to have the same kind together and always in paying quantity. His principal idea in raising fruit seems to have been to have fruit ripening all through the season. Beginning early in June with strawberries, he followed with berries, fruits, of tree and vine, till snow was falling. His reputation for fruit brought him buyers the year round, and he always 
sold to the highest bidder. His fruit was precisely as marked-never second quality with first, and no third. He used the most attractive packages in the market and some were made exclusively for his fruit. Gradually all the fruit in the Valley was good or poor, as it compared with his. His orders for fruit exceeded the production of his own farm but he would never fill in with that of another farm. All he sold came from his own. Some thought that he stood in his own light in thus refusing to act the middle-man, but he always declared that he raised fruit and did not handle any on commission.

His fruit-farm, which was known as "The Neville Fruit-farm," was ideal in plan, location, and equipment. It comprised sixty-three acres, and he would never increase it though he might have bought a score of farms had he pleased. "I don't believe in walking too far for a cherry," he would say; by which he meant that an acre of cherry trees, bearing to their limit, was preferable to a greater number either less productive, or to a greater acreage no more productive. He insisted that there is a practical limit to highly profitable fruit-farming; for example, that thirty-five acres of grapes are enough for one man to care forthat is, one owner. So not another acre would he have in vines, but he raised eight tons of grapes to the acre, which was equivalent, as the Valley averaged, to a vineyard of one hundred and fifty acres. He intensified the grape industry, and produced as much on one acre as his neighbors did 
on six. This is what he meant by refusing to buy more grape land. In walking over thirty-five acres he traveled no farther and labored not much more wearily than did the owners of six times his area. And he would not grow varieties; his one grape was the Concord. "I know the Concord and it knows me," he would say; and this mutual acquaintance, almost rising to friendship, yielded him over two hundred tons of Concords quite every year. "I have missed fire," he said one October day. It had been a cold, rainy year; insects and worms and fungus rampant and the market poor. "I don't run the weather." But I noticed that his grapes were better than any others in the Valley and few of them of second quality. Other vineyards stood out under the same sky, but he so managed his that they showed slight effect of the bad weather which had filled the Valley quite the season through. On asking him how he managed to escape the weather he replied: "I sail with the wind, not against it." This meant that the engulfing rains of the season damaged him not at all. His land was so thoroughly drained that surplus water could not remain long enough to harm the vines. When other orchards and vineyards were eaten by insects and stifled by fungi, Neville's, though infested, were but slightly injured, for he fought these pests every year, and, keeping his plantation quite immune, anticipated their ravages. "I always do as if everything ought to be done," he would say, and would spray his vineyards when his 
neighbors considered spraying superfluous. But it was not the spraying that was his sole protection. "Feed the bugs too," he would say, and enriching his soil, he fed the vines so bountifully they could be attacked by the pests and yet not seriously suffer.

His orchards were like his vineyards - small in area but intensively productive. When his neighbors were picking two bushels from the cherry tree, he was picking five; so his cherry orchard of ten acres was equivalent to twenty-five of his neighbors, and his peach orchard of eight acres equaled their twenty. His prune orchard of eight acres surpassed any other of four times the acreage in the Valley. It was wholly a matter of intensive farming. "If the land gives me six hundred dollars an acre, I guess I can afford to put a little back," he said, and would expend seventy-five dollars an acre without hesitation in fertilizer. He had quite old-fashioned notions, however, about fertilizers and called the commercial ones "patent peaches." So the cars of barnyard manure which he managed to bring in from city stockyards - a very long train they would make in a year-were of what he called "the real thing," but I noticed that he mixed "the real thing" with many a ton of "patent peaches." Neville was always hauling fertilizers and covering the land, though he never allowed the cover to remain long above ground. "The wind is a thief and the sun is always stealing," was his comment; so he plowed in his fertilizers as soon as 
possible. Winter seemed to be the favorite season with him for feeding the soil. Not a row of grapevines or of trees was overlooked in the distribution, and seemingly his ground never froze, for I have known him to plow when the snow lay several inches thick. But beneath the snow lay his last cover of fertilizer.

It was Neville who introduced vetch and soybeans into the Valley, and, possibly, cowhornturnips as a cover- or soil-crop. The vetch and the clovers often stood ten inches high at grapepicking time. He would smooth the growth down with a stone-boat and, sometimes, by paying a little higher wage than usual. "Blanket the ground and it will keep warm and be ready for you," he would say when putting in his cover-crop. "Don't let the soil get cold feet," was his prescription for a large crop of berries in June. I never quite agreed with him about sub-soiling-a soiltreatment he always practiced if possible, but as his orchards and vineyards became older and their roots possessed the ground he abandoned sub-soiling. If he had a fad it was for drainage. I think he was always ditching and tilling his land; his farm, as I remember it, was like a city streetalways torn up. Most farmers would have been contented with the natural drainage, as those whose property sloped to the North, but Neville must improve on Nature and drain every pocket. "More money in drains than fertilizers," he would say. And he drained deep, digging wells far 
down into the very coarse gravel; laying them up carefully with flat stone like an ordinary waterwell, and covering them with large stones, or, in later years, with cement tops, below the plowpoint. To this well he laid tile drains and so kept every foot of his land thoroughly ventilated and dry. "I'll see to the watering if it doesn't rain," he would say, which meant the constant stirring by the cultivator, and not a plant on his farm was ever known to wilt for lack of moisture.

He was rather a heroic trimmer of tree, bush, or vine, but never was the excided limb thicker than one's finger. "Cut them when they are little and they don't feel it," he said to me one day when I remarked on his ceaseless trimming. "All you want is sunshine and a penknife," he continued; and he let more light into the tree. "Any time when your knife is sharp," was his answer to my question as to when to trim. So he had no special time, like his neighbors, but all times.

Just how he could detect varieties before they blossomed or fruited was a mystery to me; he was born with the master-fruit-grower's eye. No nurseryman could deceive him and none tried,the second time. Yet, despite his unerring skill in distinguishing varieties, he never propagated them. "I'm not running a nursery, but a fruit-farm." There was more money for him in raising fruit than in raising vines or trees.

So famed was his farm, nurserymen competed to sell him choicest fruit-stock, for his word was their 
prosperity. Rarely would he recommend any variety. "You can never tell what pranks a tree will cut up," he said to a neighbor who asked him to recommend some variety of cherries. "I take the kind I like best." $\mathrm{He}$ always spoke of his orchards and vines as his friends. I think he communed with them in their own tongue, for he understood their secrets. They seemed to make their wants known to him and he treated them with as much consideration as a member of his household. For this reason I think he would not enlarge his estate; he knew his own limitations, and was wise enough not to attempt too scattered a friendship. Hannibal is said to have known personally all the members of his army; Neville seemed to know each vine and tree as an individual friend. While he ran a fruit-farm, he also made a companion of each tree and vine on it.

Herein lay his secret, his incommunicable secret. "If a man would have friends," so runs a saying in the ancient Book, "he must show himself friendly." And again, "The tree of the field is man's life." Neville knew how to be friendly with peach tree and cherry, with prune and with grape-vine. I do not know how he maintained this relation, unless, as once he hinted to me, by association. Trees and vines were part of his life and so he understood them. Often have I seen him wandering alone among the rows of the vineyard, fingering the broad, swinging leaves; or under his peach trees, feeling limb and bark, as it were caressing the tree. 
And when the wind had twisted and lacerated one of his trees, I think he was as hurt as had some one wounded him. He would bind up the broken boughs and never weary of helping the tree recover. One of his fads was to have all his favorite trees and vines photographed, and on winter evenings he loved to sit by the open fire and look over the pictures, just as one likes to look over the faces of his friends. He would speak of "Sparta," "Athens," "Utica," "Rome" with fluency; these were his names for favorite vines and trees. It seems that in his boyhood he had become deeply interested in ancient history and knowing no better names he dubbed his best horses, "Castor" and "Pollux," and one of his cows prospered under the name of "Proserpine." "Old Ajax is doing nobly this summer," he remarked to me, one July day, amidst the cherry harvest. He meant the middle tree in the third row, near the drive-way. How he remembered his long catalogue of Greek and Roman names I cannot surmise, unless precisely as the captain of the company comes to know his men by name-by association. But it sounded odd to hear Neville gravely instruct the pickers to "pick old Socrates clean," meaning a dumpy, but very prolific Italian prune tree at the corner of the orchard. I believe that he had a way of fighting the world's battles o'er again, with the aid of his vines and trees, for one afternoon, when I happened to be riding with him along the north side of his farm from whence it lays clearly spread out like a map, 
he suddenly drew up "Castor" and "Pollux" and pointing with his whip-stock to this section and to that laid out the battle of Marathon, and said that the dumpy Italian prune tree was "old Socrates running away."

I once ventured to ask him where were Wellington and Napoleon, but he had no trees so modern, nothing later than Julius Cæsar.

These peculiarities of Neville, which I may call his "classic shades," would have isolated him from the community had he really lived apart from it, but his look was forward, however backward his search for pet names to his trees. He never emphasized himself-only his peaches and his grapes, his cherries and his prunes. As some fond parents thrust their children into the public eye on all occasions, Neville planted his trees and marketed his fruit. Had he not been a childless man perhaps he might have cared less for his vegetable friends. "They never quarrel," he said of his Concord grapes, one morning to me.

It was the morning after that notorious day when the local council had "sold out" to the trolley company and had given them a lease, running ninety-nine years, to extend their double tracks through the village over the main road. Part of Neville's fruit-farm lay within the village. He had advocated a lease for not more than twentyfive years, with restrictions favoring the village; that the company should pave the street, keep it in order at all times; stop its cars at designated points; 
carry its feed-wire underground, and construct a siding with freight-station and convenient approaches; but the council was found to belong to the company, for all purposes. "They never quarrel," was his solace as he again sauntered among his trees and vines, "And they never cheat." "Ajax," "Socrates," "Alexander," even the fourteen "Pharaohs," a prune tree for each dynasty, would not have voted the franchise. "But if Socrates should do such a thing!"-he paused at the brink of the awful thought- "I'd rip him out if he had a million bushels of cherries on his back." He was always talking in millions. "What is the outlook for grapes this season?" Byron, one of the buyers from New York, asked him the day he received Neville's first shipment of strawberries. "Oh, not a million tons, I guess," and there the estimate stopped. It was "not a million quarts" of raspberries; "little less than a million baskets of peaches." Neville always gave himself an ample margin in his estimates. "And Socrates and I are not responsible," was his word of relief over the trolley deal. The real Neville was his conscience and his Calvinistic conviction that "whatsoever a man sows that also shall he reap." This, you would say, had you known Neville, came to him by accident of birth, for his forebears were all Scotch Presbyterians who had settled in the Valley while Washington was President. Yet Neville did not pose as a religious man; indeed, some of his speeches, as is not uncommon among some denomi- 
nations, were rather flippant paraphrases and applications of Biblical speech, but in his heart of hearts Neville was a whole man, as one of his neighbors described him,- " a fruit-grower with a conscience and a bank-account."

It was Neville's keen sense of responsibility which made his fruit-farm the best in the Valley. "I put the responsibility on the other man," was his remark when his neighbors were complaining of dishonest labor, tricky commission houses, robbing railroads, and the crookedness of things in general. "If I raise first-class fruit, pack it right, label it true, and get it off my hands in sound condition, I am not responsible for results." This was his philosophy. Again and again was he deceived. Sometimes he lost, but his philosophy survived. He learned what not to do. Somehow it was a loss to a man to cheat Neville. If the commissionhouse was the offender, it never again handled his fruit. If the hired help offended, he never hired the party again. If a picker put leaves or stones in the bottom of the basket, he was never suffered on the farm again. This rigidity of justice pervaded all that Neville did. He was as faithful to his land as he would have the commission house, the railroad, the consumer to him. "You can't say I did not feed you," said he to "Socrates" one May morning when he could find not one bud on the tree. "You will have to do your duty next year." And "Socrates" did his duty,-fifty-seven eight-pound baskets of cherries did the tree then 


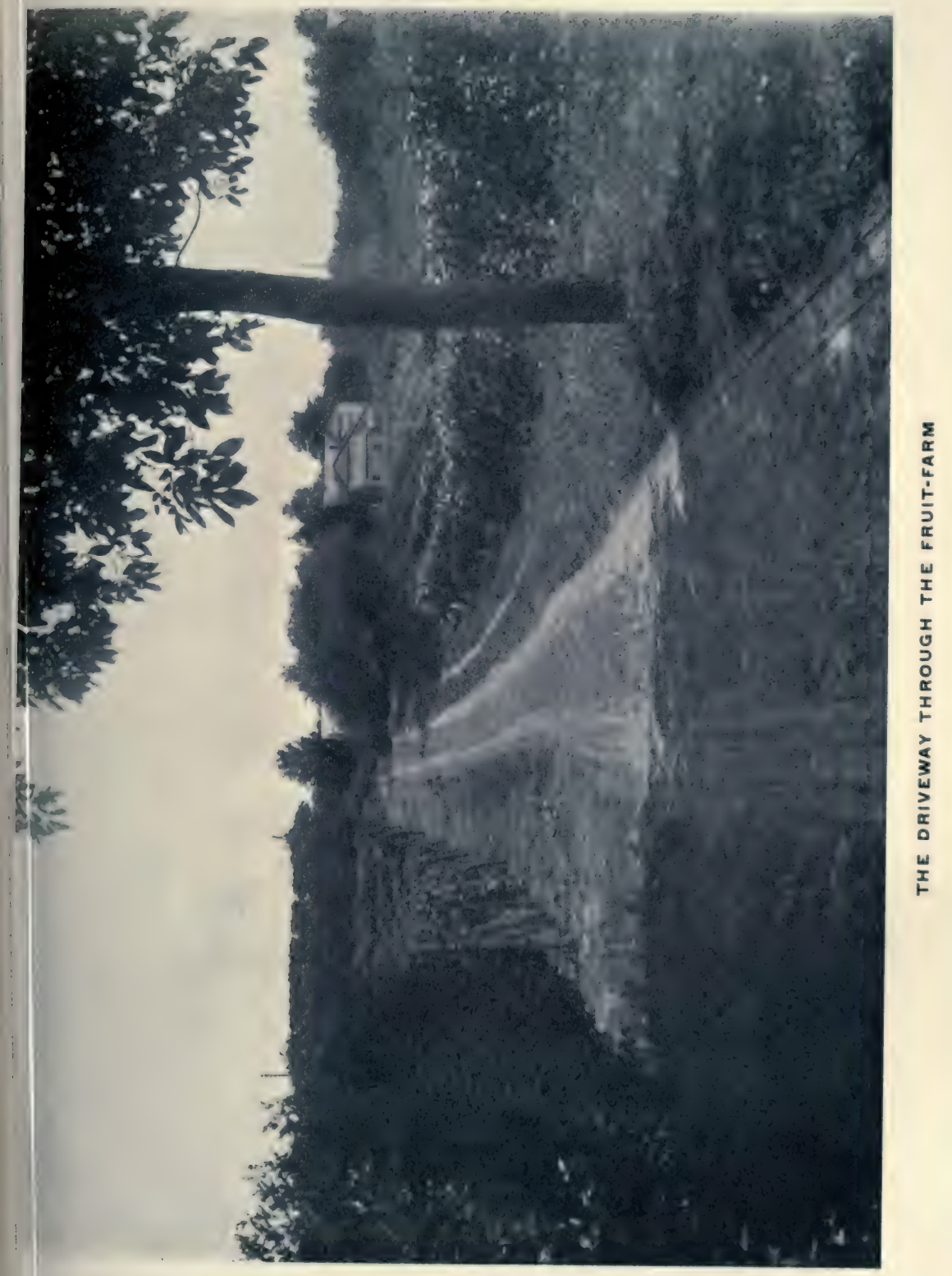



yield. I think that had "Socrates" delayed too long, say three years, there would have been another in the place of "Socrates."

I do not recall an aspect of the Neville farm which did not reflect this fundamental honesty. The roadway which passed midway through the farm was made as carefully and thoroughly as the king's road, and was kept in perfect order. Indeed, travelers through the Valley seemed to hunt out this private way for their machines, despite the warning sign of privacy Neville erected at the entrance to his estate. But a ride amidst vines and trees, in bloom or laden with fruit, and cultivation perfect, is a pleasure to the healthy mind, and the tide of automobiles flowed on, to and fro, through "Neville Farm." Posts, wires, stakes, clean rows of grapes, of trees, of berries; soil like an ash-heap; a carpet of chickweed in November beneath the vines; a carpet of clover, vetch beneath the trees; and save in mid-summer when the tools were running up and down the rows, the land always covered with green, because Neville's first maxim in fruit-culture was, "Keep the ground covered; a naked soil means an empty basket." He would point to the woods as his master: "See, Nature hides her nakedness with leaves." So he covered the earth with fertilizer and as quickly as possible grew a protecting cover-crop. "A warm soil is my coat," said he to me when I once ventured to ask him,-it was a chilly April day,whether he had not forgotten his overcoat. We 
were just stepping into the carriage, behind "Castor" and "Pollux," for a drive of some eight miles up the Valley to examine some draining he had heard about. I was doubtful as to going, for the sky looked full of showers. "A red sun has water in his eye," he remarked as he tucked the robe about him. Now the sun was not red, and, I may add, it did not prove a rainy day.

Of all men I have known, Neville could read the weather best. He never lacked a bit of doggerel verse to fit the day. It was from him I first heard:

$$
\begin{aligned}
& \text { Frost year, } \\
& \text { Fruit year, }
\end{aligned}
$$

and,

January blossoms fill no man's cellar.

And after we were on the road, this April morning, he began quoting the famous weather lines from Richard III:

The weary sun hath made a golden set, And by the bright track of his fiery car Gives token of a goodly day to-morrow.

But Neville added,

If the sun set in gray

The next will be a rainy day.

Once started on a delivery of weather proverbs, he would build up a whole weather bureau, drawers, legs, casters, and all. 


\section{Ten Thousand a Year}

So

Clear moon,

Frost soon.

When the stars begin to huddle,

Soon the earth will be a puddle.

Somewhere from Scotland must have come his,

When the smoke goes west,

Gude weather is past;

When the smoke goes east,

Gude weather comes neist.

And,

Remember it well

Your children to tell:

The wind in the west

Suits everyone best.

This uncanny prescience of the coming weather brought Neville many a visitor. The Valley turned to him for counsel, whether to plant, to pick, or to trim, for sooner or later every fruit-grower wants to know what the day shall be.

When Crawford, Neville's nearest neighbor, came to ask him of the day, Neville replied: "My boy, and you can see for yourself, have y' a pair of ordinary eyes,

"The higher the clouds, The finer the weather,

and you'll not be dripping with those clouds"17 
pointing to the blue - "these three days." So Crawford picked his sweet cherries. But a few days later, when I was worrying over the barometer and had appealed to Neville, all I could get out of him was,

Mackerel scales and mares' tails

Make lofty ships carry low sails.

And I decided to wait till the approaching storm had passed. But I think that Neville, Calvinist as he was, placed most confidence-or to speak truly of him, placed supreme confidence-in the profound wisdom of the answer to the Pharisees and Sadducees recorded in St. Matthew:

"He answered and said unto them, When it is evening, ye say, It will be fair weather; for the sky is red.

"And in the morning, It will be foul weather to-day: for the sky is red and lowring."

Neville liked to have scriptural authority even for his weather. So he read the seasons, the sun, the clouds, the colors of the sky, the stars, the wind, and even the very hollows of the air. It was an uncanny power-so it seemed to me-that enabled him to anticipate bad weather. I do not recall that he was ever caught napping in a storm. Everything about Neville Farm was ever prepared for the weather, be it good or bad. This wisdom of his contributed immensely to his prosperity as a fruit-grower. Just as he made friends with his vines and his trees, he made intimacies with sky 
and wind and cloud and the very colors of the landscape. The weather always warned him and he recognized the warning. So when his neighbors-Crawford, Moorhead, McCord, Mottier, Butt, Nash, Hampson, and so on for miles-might be holding off, as they said, for bad weather, Neville would be in full figure in his fields, pushing his work vigorously. But when he hugged the fire, most of his neighbors hugged theirs. I do not doubt that his weather-wisdom largely accounted for his bank-account.

His rigid honesty of course cost him, as it costs anyone, what some of his neighbors were wont to call "a pretty penny." Whatever detail of his estate you looked at, the thing you saw was the real thing. His teams were of standard stock, powerful animals, each capable of pulling his full share. He kept "Castor" and "Pollux" for the road; his plow teams were never on the road, save to haul loads. "A mile on the road for a plow-horse," said he, "wears him out more than five miles in the grape-rows." $\mathrm{He}$ would not tolerate any misuse of his teams, though I have seen him use the whip thoroughly and to advantage on a stupid horse. But this was the last resort. He never coddled his horses, but cared for them as members of his household. I incline to think that he attributed a sort of soul to a horse, and he certainly believed in a horse-heaven. But his curious fancy for personifying everything which has life may possibly explain this. He never sold a horse. 
When its working days were over he pensioned itso to say. He gave it the freedom of a stretch of pasture land he had bought for the purpose, up among the hills, and cared for it in winter. Sometimes he would drive up to this pasture with "Castor" and "Pollux"; draw up by the gate, and sit a long time watching the old horses in the field. He remembered all their names and seemed to have kept a strict ledger account of their deeds and misdeeds. One of his neighbors said Neville drove out to his horse lot to see whether any of his classic stock had flown away like Pegasus.

All the farm-buildings were adapted to their uses. There was nothing superfluous. His fruit-house, a large central building, was convenience. Here the handling of baskets, the making of crates, the fastening of labels on covers, went on. Hither all the fruit was brought, sorted, packed, labeled, and from thence sent to the cars. All the lower floor was of cement. He had running water in the building; gas, both for heating and lighting, and several rooms which could be used, and were sometimes used, by extra help. The tool-house, the chicken-house, the barn, were complete and always in order. The place never seemed to get dirty, or out of order. The house in which the family that lived permanently on the farm dwelt, was spacious, attractive, and a model of convenience. Unlike most farmers, he believed that the family on the farm should have conveniences as in his own house. Now every fruit-farmer knows that the 


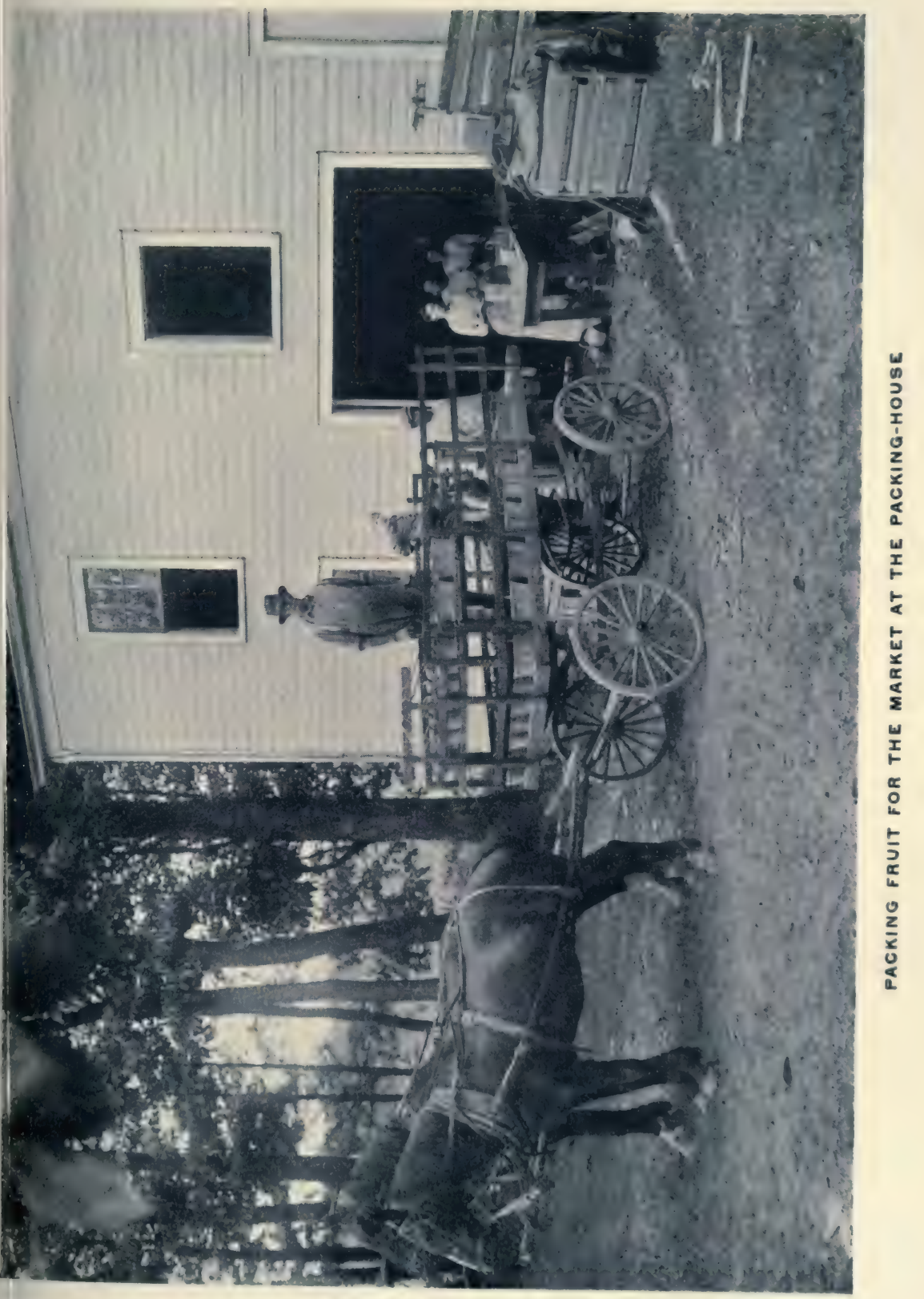



tenant is usually a very careless man in the house set apart for his use. Windows get broken; doors get off the hinges; queer things accumulate in corners; weeds grow about the house, and the whole place has a shiftless appearance. Just how Neville managed to prevent all this was his secret. "I put the responsibility on the other man," would have been his explanation. He supplied an attractive house and expected the man and his family to keep it so. He was always willing to make necessary repairs, to paper, paint, and to improve so far as was reasonable. His spirit was contagious and all who worked for him or with him caught it and carried it into their work.

Yet he found many critics. Some complained of his brusquerie and independence, of his insistence on petty details, of his being unnecessarily particular, of his exacting the pound of flesh; of his secret relations with commission houses, railroad presidents, politicians, farming-tool agents; of his prosperity. I think that at heart the trouble with Neville was that nobody else in the Valley knew just how to do as he did. Year after year, for upwards of half a century, he prospered. He never seemed anxious to get rich, yet he was truly the richest man in the Valley. He never volunteered advice, yet no man was asked for more. He never commented on his neighbors' omissions or commissions as fruit-growers, yet all the Valley kept an eye on his procedure. He never made a speech in public, never would accept office, and only towards 
the closing years of his life would he consent to become trustee of an estate, or executor of a will. Yet his hand was felt throughout the Valley. Many a barrel of flour, ton of coal, yard of cloth, and comforts miscellaneous which the poor enjoyed, could be traced to his hand. He stanchly supported school and church, but his idea of the press was summed in his devotion to the New York Tribune, in which he learned to read and which he subscribed to and read all his life. He believed that Lincoln was a saint and that Andrew Johnson was very much of a sinner. He voted for Horace Greeley for President and for a time wore a Greeley hat. He was never in New York, Boston, or Chicago, and only once could be persuaded to go to Chautauqua, and then to hear Bishop Simpson preach. He owned a pew in the First Church and was as regular as the minister in attending service. $\mathrm{He}$ never got quite accustomed to the responsive readings, or the paid quartette, nor did he believe -as once he confided to me-in free pews. In her way Mrs. Neville was an édition de luxe of Mr. Neville, but as she did not run the farm, hers is another story.

As I have recorded, he had no children, which he took as a dispensation of Providence that he and Mrs. Neville were not suitable persons to be intrusted with children, and he persistently and successfully resisted the efforts of the Lake Shore Society for the Care of Orphan Children to have him adopt specimens of the generations within 
their fold. And when the Society coolly requested him to leave it his estate, he replied, "And I'll not be doing when I'm dead what I'd not do while I was living," and the Secretary retired in despair, "for he had great possessions."

But what-I hear you say-has all this to do with ten thousand a year? Many a man, probably no man, would be Alexander Neville. This one would object to his Calvinism; that one to his exasperating sense of responsibility; a third to his ignominious love of details. But few there are who would object to his income. Nor-as time proves-was this exceptional. There are others. The Valley has its Nevilles, like Shakespeare's plays. To-day his results are more than merely possible. Any fruit-farmer who has selected the site for his farm, has planted it to the right varieties, has cultivated it in season, and has marketed his fruit with due care, may report "ten thousand a year." It is not the big farms which always pay best. Some kinds of business, some vocations, seem to have their natural limits. I incline to think this of fruit-farming. Neville set the limit of thirty-five acres for vineyards; I accept the limit. But he really made his vineyards yield as much as six times their area under the usual cultivation. So with his orchards. He intensified his trees to produce each after its kind. He was not fond of traveling many miles for a melon when he could grow one in the garden. One of his most cherished possessions was the grove, some three 
acres, of original trees, amidst which stood the farm-house. With land at upwards of a thousand dollars an acre he declined to clear away this grove. Instead, he cared for it and even replanted when trees died. He had a sense of the beautiful, and once remarked to me that if the Lake Shore Society for the Care of Orphan Children were to sell his farm, they would receive five thousand dollars extra for that grove.

Neville was a philosopher. He was much given to quotation, and his favorite lines were from Emerson:

For what are they all in their high conceit, When man in the bush with God may meet.

I never heard him quote more of the poem; possibly he did not know more. His speech ran to epigrams, some of which I here set down for the benefit of all fruit-farmers:

Feed your land and your land will feed you.

Crop your land and you lose your crop.

A hard soil means a lean purse.

Humus in the land is money in the bank.

Labor is capital; use labor well and your capital grows.

A weak plant is a perpetual loss.

Standard varieties fill the basket.

Let governments and State colleges experiment-unless you are a millionaire.

Rule of thumb is the rule for losing.

The best farmer makes the best book on farming.

It is the pennies that count; not the dollars in discarded tools. 
There are times not to do things.

Trim the plant when it is at rest; its work is to bear fruit. Much trimming means quality of fruit.

Better trim with a penknife than an ax.

Don't wound tree or vine: no man can at the same time lie in hospital and do active service.

The most profitable labor is profiting by labor.

The eye makes the package and the package makes the market.

Look out for the lean spots on the farm; one lean spot eats up seven fertile ones.

The land likes a mixed diet, but it must be fed.

Handsome fruit brings handsome profits.

Stones and culls in your package sell the other man's fruit. The quality of your fruit reflects your own. The quality shows the willingness of the land.

Don't expect more from your fruit-farm than you put into it. The man who knows all about fruit-raising has not yet been born.

His own house stood in another section of the farm. "Woods are getting scarce; pretty soon people will not know how they look. Better save this morsel as a sample." His whole farm hinted strongly of his sense of the beautiful. $\mathrm{He}$ set out hundreds of rods of ornamental hedge, and scores of ornamental trees and shrubs, and as many flowers as he could find room for. People sometimes wondered that he, of all men in the Valley the most practical in mere money matters, would fritter away his time on mere ornamentation of his estate. But he had his reward. Scores of fruit-growers in the Valley took the hint; the process of beautification begun 
by him has gone on and will continue with every generation that inhabits the Valley.

He made me executor of his estate. The care was a great surprise to me. I think he was led to the confidence by my attitude towards his wise administration of affairs. I always tried to benefit by it - a compliment which seemed to touch him. I was not surprised to find his affairs in perfect order. In the little room, off the kitchen, which he used as an office, I found the complete record of "Neville Farm." On the wall hung the survey of his estate, showing its subdivisions-its various fields of vineyard, orchard, berry, and meadow. The farm-house, and the farm-buildings were carefully plotted; the mansion house in which he had lived so long; the drives and alleys, the hedgerows, the location of all drains and drainage wells, and in a series of books, running over some thirty years, I found an accurate account kept with each section of the estate - orchard or vineyard. The books also showed, from year to year, what treatment each section had received; when plowed, cultivated, when the vines or trees were trimmed or sprayed; what material was used, and particularly, the succession of fertilizers each field had received -whether cover-crop, as clover, soybean, vetch, or turnips; or barnyard manure, or commercial fertilizer as potash, bone, or other kind. Each year was set out in a detailed balance sheet which showed expenses and receipts; not a betterment was made, a tree or vine set out, a tool or an ounce of 


\section{Ten Thousand a Year}

fertilizer purchased without due registration. So, too, every pound of product sold was accounted for, with prices, and particular circumstances, if thought worthy of notice. He carefully kept record of the commission men with whom he dealt, for his practice was never to retail fruit. All the houses he had dealt with for some thirty years were recorded, their financial standing clearly set forth. If he lost a consignment, the cause was duly set down and the name of the delinquent was struck from his books. A like detail ran into his personal accounts-but these I pass over as irrelevant. I saw now how it was that Neville knew his land so well. Every new tree set out was of record not merely as to cost, time of setting, and perhaps comment as to wind and weather, but from time to time the tree was brought to book, and if unfruitful was torn out and its place given to another. The rule of the farm was "Nothing but the best." Every inch of land was in tillage, and every tree and vine was the best of its kind and doing its best. $\mathrm{He}$ worked on the theory that only the best is really profitable. Therefore he did not hesitate to tear out acres of vineyard or orchard, at earliest moment, if convinced of their inferiority. Thus he kept his estate at the top notch of fertility and production-an expensive but highly profitable management. Whatever season one visited his farm, it was seen to be in perfect order; quite as beautiful, to the trained eye, in winter as in summer. 
The Neville farm was of a trifle more than sixtythree acres, of which fully five were in grove, driveways, and alleys. For each year I found a balance sheet so that the story of expense and returns might easily be read. Thirty acres were in grapes, ten in cherries, seven in prunes, six in peaches, four in berries, and one in garden. At times he had tried currants, strawberries, gooseberries, quinces, and grape-cuttings, and evidently with profit; but, finally, he had brought his farm to the divisions and stock I mention. He believed in specialization, and I know that he purposed lessening the variety of production. He had come to believe in grapes and cherries as dependable producers. His records showed that the grape crop had never failed. Indeed, so far as I know, the Concord grape never fails to fruit. Not every year was the crop heavy - that is, remarkable, but the tonnage always returned a fair reward. Some years, from his thirty acres he gathered one hundred and forty tons, and one year, one hundred and eighty-seven tons, which sold, on the average, at thirty-six dollars a ton. His cherry record was, taking one year with another, of heavy crops alternate years. The ten acres in cherries were seven of sour and three of sweet-the sour chiefly Montmorenci-with some Richmonds and Morellos; the sweet, Windsor and Napoleon, with some Black Tartarian. The sweet cherries bore less heavily and with less regularity than the sour. The records showed, in highly productive years, 
as high as five thousand bushels of cherries, of which about one-third were sweet, the aggregate return being nearly fourteen thousand dollars. Of this nearly four thousand dollars were from the sweet cherries. His prune orchard, the seven acres, in highly productive years, yielded twentythree hundred dollars; the six acres of peaches -and he managed to maintain the orchard, it appears, some twenty years, for it was of this age at the time of which I am speaking-yielded, in favorable years, as high as thirty-one hundred dollars. But there were less productive years, when the gross return was as low as two-fifths that amount. His garden supplied a heavy surplus over the amount used by his family. The four acres of berries-at the time of which I speak, red raspberries were producing, en grosse, some seventeen hundred dollars a year. But there were records of a similar acreage of currants, strawberries, and, for a few years, of 'black raspberries, evidently tried and, in Neville's opinion, found wanting. But most farmers would have considered them highly profitable as Neville managed to make them yield-so far as I could interpret his figures-never less than two hundred dollars an acre.

I went-out of curiosity-pretty carefully into his expense account for all the years of large and small income and discovered that on the average his yearly income from his sixty-three acres was nearly fourteen thousand dollars net. His expenses 
were heavy. His labor bill was very large because he was ever at work. His bill for fertilizers exceeded fully threefold that of any of his neighbors. He was a little fastidious as to packages and containers for his fruit, always putting it up for the market in attractive fashion; a procedure which meant much additional labor. Never a year passed without its permanent betterment of his estate, and chiefly in drainage, for it was a first article in his horticultural creed that "no land is better than its drainage." His tools were of the best but not always of the latest pattern. He kept all buildings in perfect order; was punctilious about roofs and foundations, unbroken window panes and fresh paint. Year by year he charged against his estate for interest on investment, taxes, insurance, and betterments. So, whatever the year, he could turn to its story of labor and returns.

I was interested to discover that after deducting expenses, as the years slipped away, one year with another, Neville's net income equaled quite onehalf of his gross receipts. I think that very successful fruit-growers will pronounce this return exceptional, as expenses more commonly equal more than fifty per cent. of gross returns, say from fiftyfour to sixty-eight per cent. It is a matter on which scarcely two fruit-growers anywhere will agree. The personal equation enters here, and the expense account on the fruit-farm is as variable as the personal equation, and cannot be precisely anticipated. Neville did things in a large way and indeed 
in a somewhat expensive way, on the theory that "only the best pays best." But there are many fruit-growers who think they cannot afford to do things in the best way. For example, Neville's expense for labor and for packages was higher than any other grower's in the Valley, because he was a very particular man; yet, on the other hand, he always received top prices. His labor bill was high because "he always kept the cultivator moving"; he was ever doing something of account on the farm. He estimated the value of his estate at sixty thousand dollars, which was moderate enough if one considers its annual production. Few investments of sixty thousand dollars yield an annual income of fourteen thousand dollars, together with house rent, food supply, poultry, eggs, truck, fruit, and not last or least,

\section{"That peace of mind, greatest of all."}

Whatever the income from the fruit-farm, we come at last to the man himself. If he selects the right site for his farm; if he makes the right sort of soil; if he plants the right varieties of vine and tree and bush; if he cultivates in the right manner, and gets his crop into marketable shape and to the right market, he may expect a fair income-quite possibly two hundred dollars an acre net. But the man must think and do; ever think and do. Ten thousand a year from a fruit-farm of fifty acres will not produce itself automatically. The man is the fruit-farm. 
$A^{L L}$ migratory birds are now under the protecthe Lane law, which after many years of agitation was at last passed by Congress. All who are interested in fruit-growing must choose between the destruction or the preservation of their orchards and vineyards. For years the Government, State or Federal, has labored to teach fruit-growers all over the country how to fight destructive insects and fungi; the battle has raged fiercely. But we have come to the parting of the ways. Despite all efforts to combat the evil by cultivation, and specially by spraying, the alternative remains, "Fruit or no fruit?" Which shall we take?

Recent years have brought more worms, insects, fungi, pests of all kinds into fruit sections of the country than were ever before known. For the first time many have begun to understand the story of the locusts of Egypt and the ten plagues. Never before have insect and fungous enemies of fruit done so much damage. In the Valley it was more than half a million dollars for one year. 
Throughout the country it exceeded twenty-seven millions for fruit alone, and the total destruction, including that of hay, tobacco, cotton, truck, cereals, forests, was more than $\$ 800,000,000$.

We ourselves are to blame. Never before were birds so scarce as in I912. Never before were so many wantonly slaughtered. Fruit-growers killed them, and so cut off the hand that feeds; Italians killed them for the pot. All America seemed in a frenzy to slay the goose that lays the golden egg. Folly of follies! Spray and fertilize and cultivate all we please - no birds means no fruit, no crops, no foods.

In southern France along the Riviera, one of Nature's most productive fruit-gardens, the destruction of birds by man and by cruel storms, - the seasons of 1910-1912 were among the worst known in the history of the region-resulted in the almost total failure of all fruits. They who in America live in an equally favored fruit region may well take notice. We are swiftly making a Riviera out of our heritage. Scenery is all very fine, climate is health, but the sole hope of the fruit sections of our country lies in the production of fruit. This gone, poverty must certainly come to the region. What, for instance, except the fruit can pour yearly into the pockets of the people of the Valley the vast income they usually receive-more than two millions dollars? Will the growers, will the inhabitants of every fruit valley care for their orchards and their vineyards or suffer them 


\section{4}

An American Fruit-Farm

to be destroyed by their own carelessness and ignorance?

Say what we please, our best friends are the birds. The immeasurable loss to the country by their wanton destruction could be avoided if we would only let them alone. Eight hundred millions a year! What are we going to do about it? Shall we go on spraying tree, bush, and vine and shooting birds? Shall we raise fruit only for worms-which is precisely what we are doing all over the United States. Consider the brutal facts of wanton destruction of the birds, illustrated in the Lake Shore Valley alone. In one part of that Valley called North East, which comprises the northeastern corner of Erie County, Pennsylvania, there were about seven thousand acres of fruit in I9I2, but this was so badly injured by insects that the result was as if there were only thirty-two hundred acres. This means that scores of fruitgrowers paid taxes, worked, or tried to work thirty-eight hundred acres of fruit not merely for nothing, but as a breeding ground for worms to vex them another year. Nor is the Valley exceptional; a like folly reigns in other valleys. Consider this folly as a common procedure. In a region favored by Nature for the production of a great variety of finest fruit, men produce worms! Foolishly they do all they can to defeat Nature and to injure themselves. They kill their best friends and at the same time expend thousands of dollars to make artificial friends; they imagine that spraying will 
take the place of insect-eating birds. Nonsense! Nature knows more than we. Consider the facts. The coddling moth costs America annually $\$ 12,000$,ooo by destruction of fruit and $\$ 8,500,000$ additional for spraying bill. Is that good business? One pair of potato bugs will breed 55,000,000 potato bugs in one season. One pair of green leaflice will breed ten sextillion lice in one season. Try to write ten sextillion and see what sort of a figure you have! A pair of gypsy-moths busy all summer will produce upwards of five trillion worms to feed on orchard and other trees.

Nature provides a check on these and like peststhe birds. And who kills the birds? Do you who are a fruit-farmer? Do you allow the killing of them on your premises? What will a bird do for us if we let him and his mate alone? A pair of grosbeaks in course of the day visited the nest four hundred and fifty times and each time with two or more worms. Sparrows, chickadees, martins, vireos, average a visit every minute to the nest, and two or more worms each visit. A nighthawk's crop contained sixty grasshoppers; another's five hundred mosquitoes; a blackbird's thirtyeight black cutworms, the meanest worm for tomatoes, cabbages, strawberries, and the garden generally. And in I9I2 there were more cutworms and fewer blackbirds in the Valley than ever before in its history. One song-sparrow devours more than fifteen hundred worms in one day, and this cheeriest of songsters, who abides with us the 
longest of all songsters, always lives in or near a vineyard. A scarlet tanager has been seen to devour at the rate of thirty-five gypsy-moths a minute for eighteen minutes at a time. More than fifty species of birds, nearly all of which would frequent the Valley - and most other valleys alsoif we would let them, live on caterpillars and plantlice. A pair of robins will eat, on the average, all summer long, two worms every minute and rear several broods to do the same act. And do you kill robins? You say the robin eats cherries. But the worms destroy infinitely more. You pay out money to spray your trees; the robins will do the work for nothing. And the woodpeckers, one and all, are worth their weight in gold. They do more to protect a fruit-tree than any other bird. You may see them, if you do not kill them, searching over the tree bark, stem, leaf, bud, even the blossoms and the fruit, devouring, not cherries, peaches, plums, prunes, but bugs, lice, myriads of lice. Of course we ought to shoot them and spray the tree and ask Uncle Sam to maintain an experiment station in our locality for our benefit! Is not this the climax of folly? What if the fruitgrower were to let the birds alone, make his estate a bird preserve, and put up a sign, "Pothunters, Take Warning!"

A curious calculation as to the use of birds-and one which must make a deep impression, if it be considered at all-has been made by Kalbfus: Each young bird in the nest daily consumes an 
amount of animal food equal to its weight. Suppose that there is one nest of birds to every acre of land in Pennsylvania, 28,800 acres; this means 3600 tons of insects consumed every day; of course "insects" include insect life in its three formsworm, pupa, and winged,- - not to speak of insects in the egg. On the average, is there one bird's nest to every acre of land in that commonwealth? Undoubtedly there are more. Robins live fifteen years. Few birds live out their time, being cut off by storms, famine, or enemies, of whom the chief is man. Few die of disease. Three thousand six hundred tons of insects consumed daily make how many for one summer? Figure this out and you will discover that for four months alone it makes insects enough to load a freight train nine miles long, each car holding sixty tons! And this for Pennsylvania only. What if we include all the forty-eight States? It means that during one season of only four months the birds of America -assign but one pair of birds to every acre - consume more than $3,600,000$ tons of insects, or enough to load a freight train nine hundred miles long, each car carrying sixty tons; that is, a train reaching from Buffalo to Chicago, full of the most loathsome, the most injurious, the most pestilential creatures known to man. Of course kill the birds! Of course it is better to have $3,600,000$ tons of bugs and worms devour our crops than to have these same insects ground up in the crops of birds!

A bird has a higher blood-temperature than any 
other animal. Its circulation is more rapid. It is more active also. To keep up this higher temperature, this more rapid circulation, this greater activity, it must eat more in proportion than any other animal. Birds are the biggest eaters in the world-not even excepting people who patronize picnics. This explains the daily consumption of a nine-mile trainload of insects in Pennsylvania alone. We have added in a like tonnage for the other States of the Union; add in the tonnage for Europe, Asia, Africa, Australia, South America, the Isles of the Sea! Who can compute the tonnage? Now we can dimly understand the statement made by men who speak by the strength of accurate knowledge that, if insects are not curbed in some way, this planet will become uninhabitable for man in less than twenty years. I believe that the facts warrant cutting this length of time in half. So of course, kill birds! Pass laws to kill them! Encourage pothunters to kill them! Cats, ever more cats to kill them! Kill the (cats?) birds, and, like Herod of old, be devoured by worms!

Birds are essential to human life. No birds, no people. Charles Darwin proved once and for all that there would be no soil were there no earthworms. Robins appear to have read Darwin's famous book on Earthworms. They also seem to know about cutworms and some other like friends of man found in gardens. Of course black cutworms and grubs are more to be desired than robins. Some people have the perversity to believe 
that too many cutworms spoil the tomato patch. A robin treats her family to pounds and pounds of cutworms, each summer, but she also eats a cherry! Off goes her head! How about the man who raises wormy cherries? He demands just as much per bushel-worms and all-as if the fruit was first-class. The innocent purchaser thinks that it might be a good thing to let loose a few robins in that man's cherry orchard. Does he think so? Not he. He, as is said, is saving at the spigot and leaking at the bung. No, he is not a stingy man-he gives a nickel for the mission in China. No, he is not an ignorant man-he went to school; he can read, write, and cipher. But he yearns to preserve that nine-hundred-mile freight train full of bugs; he believes in the laissez faire, the free-trade theory of worms; the let-alone theory, save as to birds; kill birds, raise bugs. If only these fruit-growers and farmers who do all they can to kill birds might have all the bugs on their farms and in their vineyards and orchards, and keep them there! But no; these are the very men who complain first and loudest and demand State and Congressional appropriations for experiment stations and the assignment of experts from the Department of Agriculture at Washington to kill insects and fungi for them-while they kill birds. The United States now protects all migratory and all insectivorous birds - or at least, the law of I9I3 was enacted for this purpose. Several States have protective laws; but as yet the hand of 
man is hardly stayed in this country from the wanton destruction of birds. The mind of our people is not yet right on bird-protection, nor will it be right until they are the law, and not one bird helpful to man by destroying insects can be killed wantonly on American soil. ${ }^{x}$

Every State has some sort of game law, the best at present, fixing penalties for killing birds "out of season," or with "automatic guns," "traps" of certain kinds, and providing for special officers to see that the law is executed. But to-day there is an army of more than $5,000,000$ men who at some time during each year scour forest, field, mountainside, thicket, and glen and kill every feathered creature in sight. There must be a bird-conscience in Americans before they will adequately protect the birds.

It appears by the census that the destruction of farm products by insects in I9I2 was more than $\$ 973,000,000$. Only a few hundred millions! What are they to a great, a powerful, an intelligent, a progressive country like ours! Not every country can feed its bugs and worms a thousand millions a year and build a Panama Canal, and four warships, and no end of post-offices, and knock off the tariff on foodstuffs, and do sundry other minor things in one year-and survive!

I There are innumerable books about birds. The best single volume, as yet, is Our Vanishing Wild Life: Its Extermination and Preservation, by William T. Hornaday, Sc.D. With maps and illustrations. New York; New York Zoölogical Society, I913, 4I I pp. 
In the State of Pennsylvania, alone during that year, the loss by ravage of insects was greater than the entire income of the Lake Shore Valley, a hundred times over.

Birds preserve the balance between all food products and insect and fungous enemies. Destroy birds and this balance is destroyed; nor can spraying restore the balance; nor can cultivation. Let Nature have her way. She is our best friend. Vain men think they know better what to do than Nature. The whole secret of fruit-growing is to be on the side of Nature. Bird-destruction means wasted work, wasted crops, the perilous increase of insect and fungous pests. What makes a farmer more wrathful than to discover a trespasser ruining his crops; stealing his fruit, snaring his fowls, catching his fish? But when a dozen turtle-doves settle down in the wheat-stubble, the farmer gets his gun, or suffers another to get a gun, and hurries out to kill. All the tramps, trespassers (except pothunters), and thieves combined injure the farmers less than the farmers injure themselves by wanton destruction of birds. Funny, isn't it?

All the strikers all over the United States, in all the strikes and destruction of property during the year I9I2, did not destroy property to more than one-tenth of the destruction wrought by insects to farm products. Farmers and fruit-growers speak severely of "strikes" and "strikers" in the manufacturing towns of the country. What may the strikers truly say of farmers and fruit-growers? 
People in the country are horrified if told that nineteen people-so the report goes-may be found living in one room in Pittsburgh. But these good country people are not disturbed by the slaughter of the birds. Consistency - so the proverb runs - is a jewel, even (as the French say) "when it is made of paste."

In one season, one San José scale will produce $3,216,030,400$ of its kind; this is the law, "each after its kind," with a vengeance. One pair of robins-probably the most useful of our common birds-may possibly in one season raise seven robins. Do you see the difference? But, you say, robins do not eat scale. There are other and more common scales, plum scale, peach scale, maple scale, oak scale, apple scale, cherry scale, blackolive scale, greedy scale, oyster-shell bark-louse scale (which is the most destructive next to the San José, and is common east of the Mississippi, and is the food of many birds). What birds devour scale? Titmice, woodpecker, orioles, thrush, waxwing, warbler, chickadee-many varieties of these birds. Scales and insects increase by the millions; birds, possibly by the half dozen. Kill the birds and let scales and insects grow ${ }^{\mathrm{r}}$

And there are farmers who say: "Give us this day our daily bread." There are fruit-growers and farmers who demand the presence of experts, and

I Read Birds That Eat Scale Insects, a little pamphlet published and freely distributed by the Department of Agriculture of the United States Government. 
appropriations from Congress - to do what? To serve as artificial birds. Kill the birds and spray Bordeaux mixture instead, and get Uncle Sam to pay the bills! Funny, isn't it?

In the public schools of the country there may be found some $16,000,000$ young Americans, the "rising hope of the nation." How many of this "hope" ever hear one word of counsel, not to say instruction, as to the value of birds to man? Thousands of them "collect" birds' eggs and nests, not without wanton destruction of bird life, but who among these rising millions learns in school the lesson of lessons worth knowing, that human life depends upon bird life, and therefore the protection of birds means civilization? What teacher, what board of school trustees knows anything or cares anything about this matter? How many millions of dollars are paid by the taxpayers to train "the rising hope," and how much is actually used to civilize the child as to the use, not to say the rights, of birds?

The word "insects" or the word "fungus" does not occur in the Bible. There are thirty-three verses, in the King James version, which mention birds directly; perhaps as many more which specially refer to bird life. We are told that "the birds of the air have nests." This is according to St. Luke. How soon must it be said, "The birds of the air had nests"? Are clergymen, whatever their church or creed, helping preserve the birds, "each after his kind"? Are they at any time 
instructing their listeners, young or old, in the value of bird life to mankind? Or is "slumming" more interesting? Or "politics"? Or a course in sociology or the "higher criticism"? Or "the missions on the Congo"? Palestine is a birdless country; it is mostly a wilderness. Why a wilderness? Clergymen are public teachers of immeasurable influence. Are they "with us or against us" in the sane attempt to give the birds a chance? There is one text in the Bible from which if the preacher does not at once preach he may never again have the opportunity, because the text will no longer be true. ${ }^{\mathrm{I}}$

Sometimes, when clerks break loose from banks, stores, and other places, they become "pothunters." They want to shoot everything in sight, in the bird line, on holidays: robins, thrushes, martins, wrens, woodpeckers, pigeons, owls-and so on through the list. Why not? Who owns the birds? Who objects? Shoot the robin and throw the carcass under the bushes! Only a few hundred million more bugs to eat up food crops; that is all that shooting a robin means. Query: Do clerks eat wrens, martins, field-sparrows, robins?

During the winter of I9II-I9I2, the "city council of Pittsboro, South Carolina, rescinded an order forbidding shooting within the city limits so that the people might shoot robins that had been driven by a severe storm into the town to seek food and shelter. About four thousand robins were

s Song of Solomon, ii., I2. 
killed. The mayor of the city, who was away at the time, was so disgusted at what had occurred that he resigned his office upon his return." This delightful bit of history graces the pages of a bird report in a distant State. ${ }^{X}$

Shall all the birds be destroyed? Shall farmers and fruit-growers help the destruction and stand the loss? How many millions of dollars? Far more than the value of all the products of all the fruit sections in America. Do steel-manufacturers combine for their own interests? Does the Standard Oil look out for its own? Does the papertrust, the lumber-trust, the cotton-trust, the booktrust, the woolen-trust, the steel-trust, and so on to the end of the trusts, if an end there be? Do farmers and fruit-growers look diligently out for their own interests? Would the Standard Oil, that finely organized and well managed concern, deliberately refuse to omit anything, however laborious, which, if done, would add to Standard Oil values? But farmers and fruit-growers kill the birds that feed them. They depend upon their labor and their crops; they work; they think they work harder than any other workers in America. Yet they kill, or permit to be killed, the chief source of their wealth, - the birds. Indeed, of all the people on this planet, farmers do the least in their own interests. They refuse to get out of time-worn ruts. They are suspicious of everybody. They kill their

\footnotetext{
${ }^{2}$ Report, Massachusetts Board of Agriculture, January I5, I912, p. 28.
} 
best friends. This is not a libel, but a terrible fact. And yet the farmer is the most independent man in America.

Every American farmer may risk his last dollar on this truth, unpleasant as it may sound, that fully one-fifth of his efforts is wasted absolutely by the destruction of his products by insects and fungi. On many farms the waste is greater than this. Powerful "trusts" protect themselves and compel others to "keep hands off." Farmers and fruit-growers refuse to protect themselves by simply letting Nature alone. Let the birds live! Who butters the farmer's bread? Do not forget: it was a bird that brought the prophet his daily bread.

We now have more laws protecting birds than ever before, but, unless the mind of the people is behind them, they remain dead laws. All men who are truly fond of hunting are the best friends of game and of the protection of bird life. The time has come when as a people we must take our choice: dead laws, dead birds, dead vines, dead trees, dead labor, or living laws, countless birds, orchards, vineyards, abundant crops, lower cost of living.

Meanwhile insect pests and fungi are increasing, as they are increasing in every fruit region, in every farming region in America. The natural check on these enemies is the birds. Why destroy the birds? Why not protect them? What fruitgrower would refuse a gift of a fertilizer that would increase his annual harvest twenty-five per cent.? 
Or would he reject an offer of labor that would work out that increase? But the farmers and fruit-growers of the country may have this increase for nothing if they will protect the birds. On the low estimate of one bird's nest and its brood for every acre of land, the birds of Erie County destroy in one season of four months - and the ravages of worms and their destruction by the birds is for a longer period - the enormous total of 125,000 tons of insects! This means six hundred and twenty-five tons every day during the season. But there are more than one nest and a brood to every acre, and birds do a greater service than this consumption of enemies of orchard and vine. In the single county of Erie, and chiefly in the Lake Shore Valley, the birds, assuming one pair for every acre of land, destroy in one season enough insects to fill a freight train fifty miles long, each car holding thirty tons! A similar train may be drawn out of every fruit valley in the United States,- -by the birds. Shall we kill them? Is it even good business to protect them? During the season these friends of ours destroy thirty pounds of insects on every acre of the farm-that is, more than a ton of insects in one season on a farm of sixty acres. What fruitgrower would like to handle a ton of bugs and worms? There are innumerable species of fungi which ruin tree and vine, bush and plant, bark, root, leaf, bud, flower, and fruit; no part of the living plant is exempt. Not all fungi are bird-food. We do not know exactly the amount of service the 
birds render us in destroying fungi. We do know that birds eat the scale-the widespread and numerous woodpecker family, the house-sparrow, the tree-creeper, the long-tailed tit, grosbeak, oriole, warbler, wren, chickadee, waxwing, vireoin all, some fifty-seven varieties of birds, all of which feed on the scale. Of these, twenty-seven varieties destroy the two most destructive scalesthe black-olive scale, and the oyster-shell barklouse. Fungi are vegetables, plants, growing from infinitesimal seeds called spores, which in countless numbers float on the wind and suck the life out of other plants. At present our chief defense is judicious spraying.

From I900 to I9Io the value of farm property in the United States increased one hundred per cent. -that is, from $\$ 20,439,900,000$ to $\$ 40,991,450,000$. During this period the value of land increased one hundred and eight per cent. per acre, but the population of the United States increased only twenty-one per cent., which means that, relative to population, land is acquiring a scarcity value. Indeed, the increase in farm values was a significant, probably the most significant, increase among all the changes in the affairs of the American people. Of every one hundred of our people, fifty-four live in the country; forty-six in the city. The actual land area of our country is just short of $2,000,000,000$ acres, and of this enormous area only twenty-five per cent. is improved land. On the other hand, forty-six per cent. of the whole is actually farm 
land. This means that quite one-fifth of all land called "farm land," throughout the United States, is unimproved. If we consider what "improved" really means as applied to land in our country, we must admit that farming here is as yet extensive rather than intensive, and that bad farming is the common practice.

During the last twenty years an amount of capital far beyond accurate computation has gone into farming, and this form of investment has only begun. The city man who puts $\$ 30,000$ into a farm may now be found in every prosperous farming community. Hundreds, thousands of farms - fruit, stock, poultry, truck, cranberry, and so on through the list-are owned and operated by rich men who made their money in banking, manufacturing, railroading, medicine, politics, patents, speculation; with them the "get-back-tothe-land" instinct is dominant. In the Lake Shore Valley, and in other valleys, scores of such men may be found and almost without exception their farms are highly profitable. All over the United States such men may be found, and because of them a new profession, a new vocation, exists in America, that of "farm manager," "superintendent of the fruit-farm," "horticulturist," and thousands of young men are in training on farms and at agricultural colleges and special schools to fill these positions. This astonishing change in affairs goes far to explain how it happens that the value of farm property increased between 1900 and 
I9I0 from twenty billion to forty billion dollars. Now during this decade there was but a trifling increase of land in farms, that is, less that five per cent.; for the acreage in 1900 was $838,600,000$, and in 1910, 878,800,000; and the increase during this time in improved land was only fifteen per cent., that is, from $4 \mathrm{I} 4,500,000$ to $478,452,000$ acres. The large fact is that farm-lands increased in value chiefly because of better farming.

No small part of the credit for this increase is due to such men as Burbank and Bailey, and particularly to the men who have charge of experiment stations; and to such work as is done by the Department of Agriculture at Washington, and similar departments of the State Governments. Our people seem at last to have awakened to the enormous importance and almost infinite opportunities and possibilities of farming in its many phases.

What do all these big figures and big facts amount to? "Where the treasure is, there is the heart also," says the Book of Books. When the American people have an investment of $\$ 40,991$,450,000 does any one imagine that somebody's "heart" is not "there also"? Does any one imagine that the millions of Americans engaged in farming, if they have any conception of their own interests, are going to permit a wanton waste of from twelve to twenty-five per cent. of their investment annually? Or, will they awaken, save this waste, and capitalize it? 
Does the United States Steel or the Standard Oil permit any such waste? Does the Pennsylvania Railroad, or the Vanderbilt, or the Harriman, or the Baltimore and Ohio, or the Pacific? Does the Cunard Line, or the American, or the Allen? Does any human being, who can be left safely at large permit an annual waste in his business of twelve per cent.? But farmers and fruit-growers permit this waste; they are the guilty party. The farmer will fight the railroad when it attempts to take in a few rods of his land to widen its tracks. He will go everlastingly to law with his neighbor over a disputed fence-line when all the land in dispute is not worth fifty dollars; and at the same time he will suffer himself to be cut off twelve per cent. and more every year, and will actually superintend the wasting so as to make it larger. He kills protective birds himself and encourages everybody else to kill them.

At least twelve per cent. of all our land products are yearly destroyed by worms; yet, beginning in Texas and Florida and continuing to the Canadian border, from ocean to ocean, the wanton and wicked destruction of birds goes steadily on. Wealth is rapidly retreating to the country, to the farm, to better farming and fruit-growing. "Things," says Emerson, "refuse to be mismanaged long." The increase by more than twenty billions of dollars in farm values from $\mathbf{I} 900$ to I9I0 means the necessity of bird protection. Owners of such wealth will not tolerate a twelve 
per cent. yearly waste of capital. Nothing is gained by calling a spade by any other name. A spade is a spade; a bird is a bird; a farmer is a farmer. A wise farmer is not a foolish farmer. But will the wise man forever suffer the foolish man to injure the wise man? If the foolish fruitgrower or the foolish farmer will not protect his own, and thereby he injures his neighbor, shall the neighbor submit tamely, quietly, smilingly, and charge up the loss and no more, or shall he defend his own substantial interests? A wise farmer is better than an act of Congress or of Assembly. How long will the farmers and the fruit-growers of the country slumber and suffer this wanton injury? How long will they submit to this yearly loss of at least one-eighth of the just results of their labor? Are they less capable than the Standard Oil, or the Cunard Line, or the General Electric? Come on, men of wealth, and buy up the farms! Improve them. Welcome Burbank and Bailey, Experiment Stations, Schools of Agriculture! Welcome governments, of Nation or of State! Welcome all associations, societies, granges, clubs, meetings, books, newspapers, speeches, conversations, ideas-welcome all actual thinking that favors the protection of the birds!

If farmers and fruit-growers do not suffer birds to be destroyed, will their profits at the close of the year be twelve per cent. increase? This depends upon how our neighbors act. Our birdneighbors are in Florida, Alabama, Georgia, 
Tennessee, Virginia, Maryland, California, Maine, Minnesota,-in every nook and corner of our country. Bird-protection is not merely a local but a universal need. A fruit-grower may live near the northern edge of the country. All the way southward the birds are remorselessly and wantonly destroyed the whole year through. Practically, people living at the North get only whatever birds escape our neighbors at the South. In Tennessee millions of insectivorous birds, especially robins, are killed for fun and for food during the time of their migration-February and March. The wild pigeon, once best known of migratory birds, has become extinct through wanton destruction, yet there are thousands of men now living who can remember when the sky would be darkened by immense flocks of these birds in flight to or from their breeding-grounds. Alexander Wilson computed that one flock of these pigeons which he saw passing over Indiana contained 2,230,272,000 birds! This was two generations ago. On September 14, I908, the last wild specimen was taken near Detroit, "the last that ever will reach the hands of man," for not one bird of this species is now in existence. Yet, some years after Wilson recorded his observations, the Legislature of Ohio refused to pass any law protecting the passenger pigeon on the plea that the birds were so numerous they could not decrease, much less become extinct. To-day we must add to the rapidly increasing list of extinct species of useful 
birds-in our country alone-the Labrador duck, the Eskimo curlew, three species of the macaw, and the Carolina parakeet. And our common birds - robins, orioles, sparrows (not the English sparrow, that insufferable scavenger, but our native species), bluebirds, martins, chickadees, turtledoves, owls, night-hawks - are rapidly perishing by indiscriminate and senseless slaughter.

Ten cents a dozen for robins seems a fabulous price to the thoughtless Tennessee mountain boy, and to kill thousands of robins in Georgia, Alabama, and the Border States, generally, while the birds are migrating, means a birdless tract to the North. The robin, or, properly speaking, the thrush, is only a type of the victims. After the entire South has spent months in destroying useful birds, the entire North takes up the work of slaughter and continues it till the last escaping bird takes its flight southward into the camp of its enemies. The miracle is that a single bird survives.

A twelve per cent. profit from birds means a common-sense treatment of them everywhere and at all times. Foolish, selfish, murderous man is blind to his dependence upon birds for his existence. Every species he kills to extinction only marks his progress toward starvation, for he is hastening the day when the world will be uninhabitable for man. The oceans have northward and southward currents, polar and equatorial currents, vast rivers in the sea which, starting from the equator, flow northward and make the temperate zone inhabit- 
able, and flowing from the poles toward the equator do a like service for the hot regions. Rivers of air also flow from the equator to the poles, from the poles to the equator, and the motion of the earth through space imparts to the rivers of sea and air a vast spiral motion so that all regions of the earth are reached and affected by this vast circuit of aërial and marine ventilation. Not less remarkable are the annual bird migrations from equatorial regions northward into our temperate zone; southward into the temperate regions of Asia, Africa, and South America. Back and forth this river of bird-life flows, and has flowed through the ages. It too has its function in maintaining the nice balance of life on the globe. Happily we cannot destroy the rivers of the sea or of the sky, but we are doing our best to destroy the equally helpful and necessary river of birds. But-“'Stop! Look! Listen!" Destroy the birds and in less than twenty years mankind will literally "be eaten of worms."

The world is filling up; the continents and the isles of the sea are becoming peopled. There are now one hundred millions of people in the United States. When George Washington was President, and our country was bounded by Canada and the Floridas, by the Atlantic and the Mississippi River, there were only three million people. How long before there will be five hundred million-yes, five times five hundred million? You say, "What's that to me?" What generation-your children's 
children-will be saying, "Oh, that my fathers had been wise in their generation!" But we are not raising the children of to-morrow-we are killing birds. That is our business; let posterity take care of itself! But here a footnote from your inmost mind: Do you wish that your grandfather, or even your father, had been a little more "foresighted"? Do you blame anybody for using up the forests, for polluting the rivers and streams, for destroying the game, for wasting the resources of the country? No man lives for himself and remains a man.

The annual tide of bird-life sweeping in upon us is a diminishing tide; every year, smaller; drying up like our rivers and streams; vanishing like our forests. Instead of letting this river of bird-life cleanse our orchards and vineyards, we scatter a pinch of Paris green, spray a tiny stream of Bordeaux mixture, and do the work ourselves. The birds would like to do it for nothing, and far better than a sprayer. "No, thank you," says the fruitgrower; "no birds for me! If you see a robin in my orchard, 'Off goes his head!' I prefer to kill birds and to scold about wormy fruit and to insist that Congress shall make a handsome appropriation to kill the worms." "Is not the life more than meat, and the body than raiment? Behold the fowls of the air!" But our eyes are glued to a gun barrel. However, if any person should happen to hand the fruit-grower in the Valley-doubtless in other valleys - a twelve per cent. bonus on his 
investment, he will be on the spot to receive it, promptly, with his bag.

If after killing our common birds the farmer would take the trouble to examine the contents of their crops he would discover that forty-five percent. is insects, thirty per cent. vegetable matter, and twenty-five per cent. seeds, chiefly of weeds. The contents vary with the season, being greater in insects in spring and summer; in autumn, greater in seeds of weeds. But man is a killing animal. All our folk-lore abounds with stories handed down from our remote ancestors of killings of man, beast, and bird. What boy, seeing a bird, does not yearn to kill it on the spot? A boy, a stone, and a bird; a man, a gun, and no bird! Cruelty to animals? But we cannot eat our cake and keep it. The clock strikes warning; the time has come; we must choose between fruit, food, and famine; between birds and worms.

Now birds, like men, must have food. What food? Nature, in the wild, supplies her own with nuts, buds, leaves, roots, seeds, flowers, and the infinite variety of animal species. Species feeds on species; this is the law of life on the globe. We have cleared the land and destroyed the sources of food for the birds. Much of the so-called injury to fruit and other crops wrought by birds is wholly due to the necessity we have imposed upon them. Forests, shrubs, bushes, weeds, wild fruits, and berries and all that world of life on which birds feed in a state of nature we have quite destroyed, or 
so reduced that the birds must resort to our trees, vines, shrubs, and plants, and to the insects and fungi which we indirectly propagate - or perish. Civilization means largely the disturbance of the wild. Civilization shears off natural vegetation and introduces cultivated or man-made varieties of plants with resulting plant diseases. We also compel the insect world to feed upon our plants, having destroyed all that vegetable life on which it formerly fed. So both insects and birds are compelled to forage in our orchards and vineyards. What must follow? A bird famine or a man famine? Or shall we protect our own interests, ward off famine, by raising enough for the birds and ourselves also? Bird-food must come from insects, fungi, or plant life. What is natural birdfood? Elderberries, mulberries, wild cherries, pokeberries, Virginia creeper, juniper berries, holly berries, hackberries, huckleberries,-and these are the natural food of some sixty-seven species of birds. Does anybody plant mountain-ash, silverberry, Chinaberry, buckthorn, barberry, peppertree, snowberry, viburnums, sumac? But these are bird-food. Juniper, black-currant, Juneberry, red raspberry, black raspberry, blackberry, sarsaparilla, bird-cherry, hobble-bush, red osier, choke-cherry were growing in American valleys for ages before La Salle, Father Hennepin, and their brave companions caught sight of the "Great Lake of the Cats," which we call Lake Erie, or discovered the great West. 
But let us be more particular and look more closely at our native bird-food supply: red-cedar, mulberry, pokeberry, sassafras, spice bush, blackcurrant, the raspberries, frost-grapes, dogwood, blueberries, snowberries-and the list might be lengthened. Call the roll. Do any of these wild things answer "Present"? Are any of yesterday? Where are the dogwoods, the fox-grapes? Gone, and the birds that fed on them. If a man cannot get bread, will he eat a stone? Or will he throw the stone and eat the bird? If the birds cannot get their daily bread will they eat stones? Or will they turn to garden and orchard, to field and farmyard, and get wounds to their death? "Yes," says the farmer, "but I can't keep my land in the wild just to feed birds." "True," replies the bird, "but I must eat, and whereas I once fed bountifully on mulberries and poke-weed, now I must feed on cutworms, cabbage-lice, and some tame fruit-very tame." The farmer is loading his gun. "But I pay my bills," resumes the bird with its weather eye on the gun barrel; "and really, I prefer choke-berry to cabbage worms; but you, friend farmer-just put down the gun, please, till I am through; you have cut down all the choke-berry and set all out to cabbages; if I can stand the change of diet, certainly you can stand-just point the other way, please ! - to let me alone."

"Bang! Well, that robin won't eat no more cherries off my trees!" And Farmer Grimstone reloads. 


\section{Listen to our wise friend Professor Bailey:}

The mulberry, of almost any variety, will thrive almost anywhere in America, though you better select your variety for your special locality. Try the "New American," called also the "Downing." Plant mulberry trees and you will have birds and birds and birds, and your orchards and gardens will not be molested-at least by birds. Indeed, you may have cause to wish that the birds would eat worms and let mulberries alone. Mulberries fruit with cherries and strawberries and raspberries and early fruits generally.

For untold ages the inhabitants of Italy, and of the shores of the Mediterranean generally, have slaughtered birds without discrimination. And this wanton destruction of all bird-life is characteristic of Southern Europe. Anything that wears feathers and flies is game and food to the Italians in Italy and to all the inhabitants of that vast area once the Roman Empire. No habit is more deeply ingrained in the Italian than that of slaughtering birds of any kind. They come to America with very loose, if not fantastical, notions of "liberty," - that most abused word of our age and country, - and here they immediately proceed to kill every bird in sight. Few Americans have any conception of the bird slaughter wrought by Italians in their own land and by them in this land of their adoption. They seem like savages thirsting for blood. To them the right to kill birds seems as unquestionable as the right to express an opinion about the weather.

Nature made the Italian peninsula a paradise 
for birds, but any one who has lived there long enough to see things as they are, not merely wonderful churches, art galleries, and ancient ruins, but methods of farming, of horticulture, of marketing; facts of food supply, wages, taxation,- - the rude, every-day facts of Italian life,- - soon discovers that Italy has few birds. The wonder is that any exist there.

Start, some May morning, from Menaggio, on Lake Como, for a walk up the valley into the mountains. Your purpose is to climb San Croce. On the winding way you cut across the fields. What is this rude "rick" or tower you see by the copse of bushes? This "Roccolo" embowered amidst concealment? As you pass, a low-browed, swarthy, ill-kept man, with rings in his ears, opens the low door and glares upon you. You have disturbed him in his lair. As you came up the hill you heard birds whistling, crying, calling to their mates. Where are they? None are in sight. Now you discover that these cries came from the low, dark, shabby tower. You see a sight that sickens you. The tower is a trap. The imprisoned birds are blind-blinded by the fowler with red-hot wires. They are shrieking with pain, calling out in agony to any of their kind. Their helpless cries are a decoy. A linnet, a fieldfare, two yellow-hammers, a red-wing, flying over the land hear the cries; are drawn by them toward the tower. See the "Roccolo" embowered midst the pretty green foliage! The birds fly to the relief of their kind! 
Suddenly, the sharp whistling, whirring sound of the sweeping hawk! But the hawk is a clever device in the fowler's hands, a sort of rattle he uses to frighten the victims. They plunge for shelter into the copse. Threads! Tangled threads, full of pockets, treacherously span the open spaces. It is a fowler's net! The entangled birds flutter frantically, hopelessly, and hang there, caught. All the time the seared and blinded birds within the "rick" keep up their piteous shrieking for help. The low-browed, dark-handed man snatches the linnet, the struggling captives lie with twisted necks, a heap of dead song-birds in the corner. And if you look closely, you will see the darkfaced man thrust a sharply pointed stick through the captives' eyes. He is proud of his "catch." He shows you two hundred birds in the corner. If you will take the trouble, you can see half a dozen "Roccolos" from this one, and you can find thousands of them all over Italy. One "rick" reported ten thousand birds during a single autumn. In the vicinity of Menaggio alone the slaughter of birds in a single week amounts to tens of thousands. Sell them? Of course. Go to the market-place, in Florence, Venice, Rome, Padua, Siena - go to any market-place in any Italian town and you see exposed for sale, regularly, redwings, goldcrests, skylarks, yellow-hammers, hawfinches, song-thrushes, warblers, linnets, bullfinches, yellow birds, redbreasts, wrens, goldfinches, curlews, jays, nut-hatches-song-birds, from fifty to a hundred 
species - for sale in bunches of three, or by the basket containing hundreds; and this in any village of Italy, Spain, Portugal, or Asia Minor. Game birds too? Yes, if they can be had, but Italians, Spaniards, wealthy, educated, refined, living in "palaces by the sea," boast of a day's plunder, hundreds of skylarks, and the like, and consider them a choice morsel, as Americans consider reed-birds.

With the millions of Italians, Hungarians, Polacks, Russians, Arabs, Bulgars, Persians flooding America, and bringing with them all the birdkilling appetite of centuries of Europe, what is to become of American birds? Shall Antonio and Joseffy and Oesterglitzyiz literally eat up American birds to the extinction of the species, as they have done in their native land? Would the farmers and fruit-growers of our country like to have the thousand million dollars lost every year in America by the ravage of crops by insects? What are we doing to prevent this loss? Does Farmer Jones, or Fruit-grower Neville run a "Roccolo"? Does either turn "pothunter"? Is Antonio suffered to roam at will over the farms cleaning out birds and game of every sort? What a man does by another he does by himself: this is sound law. What farmer lifts his finger, casts his vote, or speaks one word to prevent the destruction of birds, even on his own land? Who has ever known a farmer who took the trouble to protect birds?

And Antonio in our midst is soon heard from. 
As soon as he can, after landing, he buys a gun. $\mathrm{He}$ wants to kill anything he can cook and eat, and he makes no discrimination: robins, crows, herons, buzzards, bluebirds, owls, woodpeckers, humming-birds, orioles, ducks, - anything that wears feathers! Never in history were the birds in such peril of extinction, in America, as they are to-day. The State of Pennsylvania has had a terrible experience with alien bird-killers. Six Pennsylvania game wardens have been killed and more wounded by "alien pothunters," though the law of the Commonwealth forbids an alien to carry, or even to possess, a gun.

It is a misdemeanor for Antonio-unless he becomes an American citizen, which he hastens to do-to kill birds. Once he understands civilization of the American type he makes a very good citizen. But for centuries in Italy this indiscriminate bird-slaughter has gone on. About all the birds seen in Italy are in flight across the country. Did you ever see a nest of birds, or of eggs anywhere in Italy? Antonio ate the eggs as soon as they were laid; then he ate the old birds. Do Americans want their song-birds consumed off the earth? "All very well," says Farmer Joe, "but I don't fool along about birds; when I want to shoot 'em I shoot 'em; guess it's my land and they belong to me." But the birds do not belong to Farmer Joe; they are creatures of the wild and no individual can establish title to them. They no more belong to Farmer Joe than does the wind that sweeps 
across his meadow; or the sunshine that colors his apples. He might as well bring suit against his neighbor because the east wind blew from his neighbor's farm as to attempt to make the birds his own. And doubtless partly because of this incapacity for ownership of birds, every man's hand is against them.

Who said "robins"? What fruit-grower has killed seven at one blow, like the famous German tailor? Or has boasted that he slew five hundred in his cherry orchard? "They took my cherries, and I'll kill them," says Farmer Grimstone. "They took my strawberries, and I'll kill them," echoes Farmer Pennywit. "They cleaned out my cabbages; I'll kill 'em," shouts Farmer Truck.

And they killed the robins. A crop of dead robins. A big crop of cherries? Of strawberries? Of cabbages? That depends. But of course kill the robins. Why? Because their own crops witness against them. Examine and see:

$42 \%$ insects-19\% beetles, $10 \%$ grasshoppers, $6 \%$ caterpillars, $7 \%$ snails, spiders, angleworms.

$48 \%$ vegetable food $-47 \%$ wild fruits, $4 \%$ cultivated fruits (more in June and July than in August). What wild fruits? Dogwood, wild cherries, wild grapes, greenbrier, elder, holly, cranberries, huckleberries, barnberries, sumac. Ten times as much wild fruit in the robin's crop as cultivated fruit.

"But I watched him," interrupts Mother Grundy; "I saw him take the largest and best 
strawberries; just a 'pick' out of each one and then go to another; just sampling the whole patch. Jimmy, get your gun!"

Now a farmer or a fruit-grower never makes a mistake; never eats the wrong thing at the wrong time; never tries to grow three blades of grass on soil that will not grow one; never neglects his trees, or his berry-patch, no never. It is always the birds, or the wind, or the weather. Farmer or fruit-grower never plants potatoes and reaps Colorado beetles; or sets a berry-patch and raises grubs. But the robin eats one strawberry and nine wild fruits and as a digester fills up on angleworms, cankerworms, grasshoppers, caterpillars, snails, slugs, spiders, and beetles. Of course, kill the robins! Kill them because they eat one per cent. of their food from cherry tree and berry bush. And then, it is such sport! Think of the joy, the excitement of stalking the robin! What are lions, tigers, elephants to robins? And the foolish creature persists in nesting year after year right under the farmer's nose: in the porch vine, over the kitchen door, by the well-curb, in the old apple tree where robins nested in grandmother's time and with special consideration for the cats. What better friend has the cat than the plump, stupid mother robin, and the plumper, stupider little robins! "I don't shoot robins," remarked one virtuous farmer; "I raise 'em for the cats." Three broods a year if the robins manage to escape the cats, and the farmer, and the fruit-grower, and 
the farmer's boys, and the fruit-grower's boys, and all the other boys, and the hired help, and the pothunters, and the "turkey storm," and the wind that upsets nests, and sundry mysterious enemies that swoop down upon the birds while the farmer is at church.

Watch the old birds. Every minute, from sunrise to sunset, and long in the twilight, they bring food to their young, - sixty worms, bugs, beetles, moths, slugs an hour. Make your own calculation. How many robins at work and eating worms? How many pounds of bugs and worms consumed during the season? Credit the robin with thirty pounds. Would farmer or fruit-grower rather have the thirty pounds in his crop or in the robin's? And the bird is not a robin after all; it is only a thrush. Those Pilgrim Fathers who persisted in coming by the Mayflower and in founding New England, and in doing various, very various and sundry things by themselves and their posterity, said, "Robin," when in that first spring time at Plymouth, after the most cruel of winters, they saw and heard the red-breasted thrush and for the first time felt at home in the New World. What fruit-farmer in America will not prefer cats and pothunters to robins even when they nest in the old apple tree?

A five per cent. loan on good security, with punctual payment of interest, is not easy to find. The universal law of money-lending, indeed, of all investment is, the better the security, the lower 
the rate; the greater the risk, the higher the rate. Bird-protection means a high rate of interest and no risk. Fruit-growers must risk their all for an income. A little care and labor invested in birdprotection always brings a handsome return for the trouble. Strange to say, many farmers and fruit-growers do not believe this. Because they are unbelievers in this sort of investment, they and the world at large are losers. There is an ancient saying that none are so blind as they who will not see.

The first step is to let the birds alone. Give them the freedom of the farm. Protect them by keeping hands off, and see to it that other people do likewise. If necessary one can appeal to the law of the State, and if there be no State law, appeal can be made to Federal law.

The second step is to encourage birds. Make the fruit-farm a bird-sanctuary. Avoid needless alarms. Kill cats, but in aiming at the cat be sure not to kill the bird. No pothunters; no birds killed out of season; no insectivorous birds killed at all. Build bird-houses. A tin can will make a bird-house, or a little spare time with boards, a box, hammer, saw, and nails will result in a birdhouse and ten per cent. on the labor expended. Birds really pay ten and one half per cent.!

A bird-house duly erected will possibly (not certainly) tempt some birds to stay with you. Perhaps your reputation among birds is bad "for peace and good order"; you may possibly be on 


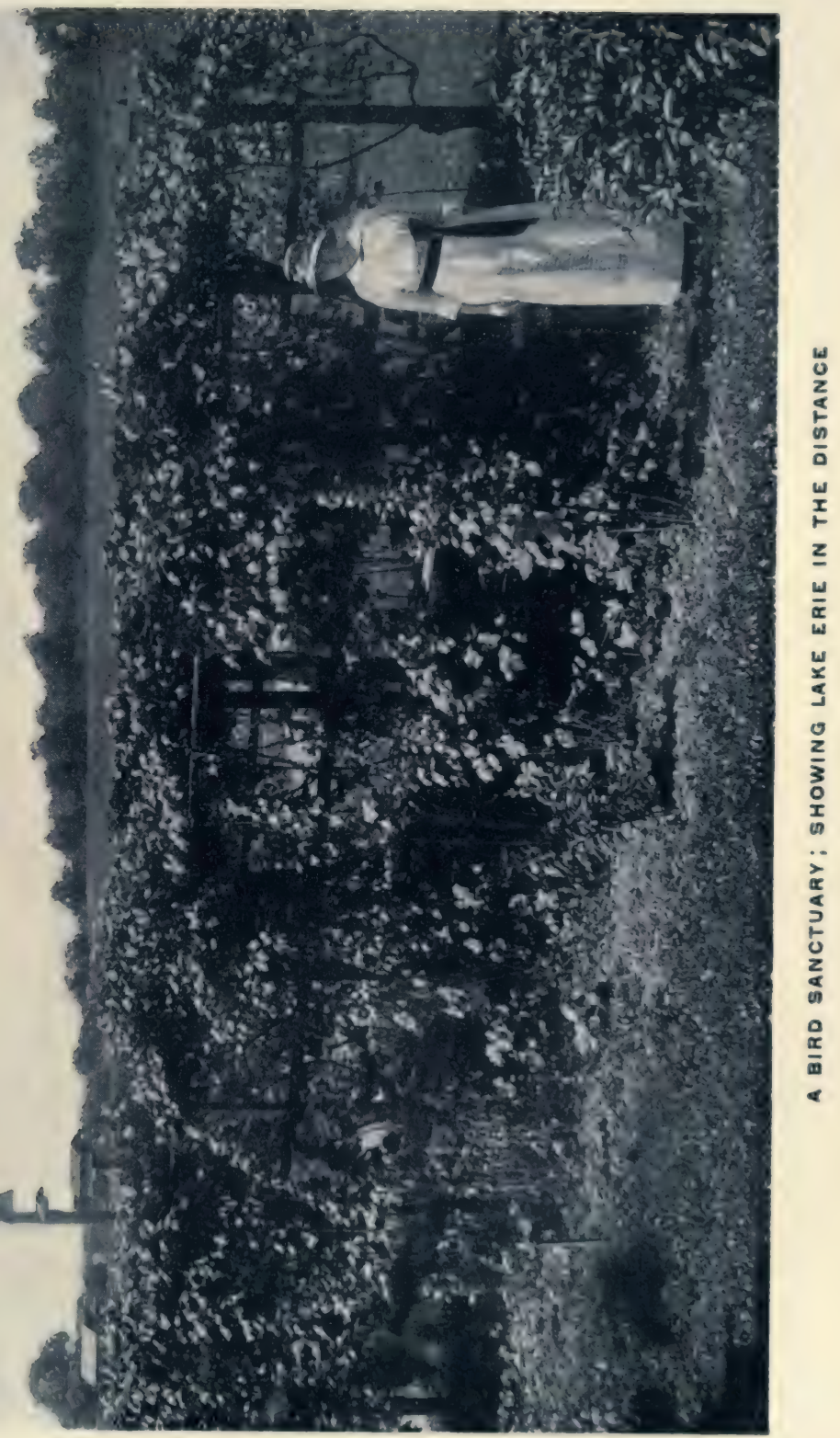



their black list. Perhaps the wrens, the martins, the bluebirds, the barn-swallows have a poor opinion of you. Perhaps they look upon you (and your cats and your gun) as avowed enemies. Of course you cannot expect a ten per cent. birdprofit on demand. Even birds know their friends, resent bad usage, and prefer worms on a friendly farm to worms and guns on an enemy farm. Try it and learn for yourself. A tin can with a family of birds within is to be preferred to a yellow, pink, blue, red, green, mansard-roofed, laundry, bath-roomed, be-porched bird-palace on a purple pole,-and no birds. Nail an empty can up in the tree and watch results; or, let the thirteen new kittens come to cathood and watch results; or, let pothunters roam over your place and watch results; or, execute State and Federal laws, and listen to your own interests, and watch results. And if you wish to amuse the children, - of course it will not interest you; but if you do wish to amuse the children, some rainy afternoon, you might obtain from the Department of Agriculture, at Washington,- for the asking,-a copy of Birds of a Maryland Farm, or the handsomely illustrated Birds of California in Relation to the Fruit Interests. Dr. Beal, the learned author, tells plenty of facts which apply to all parts of our country. Of course there is no ignorance as to birds in America. Are we not a highly educated, Christian people? Why do we want a book about birds? Would not what we do not know about birds make a book. We kill them right and left; 
we fire at them from the upper windows and the back door; we set the cats and dogs upon them; we encourage our children to destroy them; we let pothunters roam over our land to kill them, and we kill them ourselves. Providence, we are assured, helps those who help themselves, but does Providence help those who refuse to help themselves and who do all they possibly can to injure themselves? "There's the rub."

A birdless country is a desert, and any country may be made a desert by the destruction of its birds. Birds maintain the balance of life; they are the police of earth and air.

On earth: Thrushes (the robin is a thrush), sparrows, larks, wrens.

In air: Warblers, vireos, creepers, nuthatches, woodpeckers, fly-catchers, swallows.

What would we do without the aid of these feathered policemen? Will spraying be a substitute? Will chemicals? Nearly a thousand million dollars' damage to crops in America, every year, is the answer. Nature sends these policemen; feeds them; always on time and no "graft." Who are our common bird policemen? Hawks and owls; yes, despite the cooper-hawk and the sharpshinned hawk and the great horned owl, hawks and owls are among the best policemen of earth and air. Mice, rats, rabbits, moles, flies, noxious insects, innumerable, but fifty species of hawks and thirty-five species of owls are ever after these 
marauders. Protect the hawks and the owls; they are among our best friends. Every hovering bird, happening to fly above the chicken-house, in the empyrean blue, is not a cooper-hawk, or a sharpshinned hawk; be sure you are right before you shoot.

Woodpeckers? Yes all woodpeckers except the yellow-bellied sapsucker. No policemen on the farm are more valuable than the members of the great woodpecker family. And these birds surpass all others for value in the orchard.

Warblers? Yes, the entire family, and a very large family too. Nothing escapes them-larvæ, flies, scales, ants, worms, slugs, grubs, bugs, and plant lice by the million. Watch a warbler catching insects from the underside of a plum leaf, cherry leaf, apple leaf, grape leaf, berry leaf, and then conclude whether you really want to shoot him.

Thrushes? Yes, all. These are the plump, common insectivorous birds, and the robin most common of all: hermit thrush, wood-thrush, brown-thrush, all friends. Do you protect cutworms, grasshoppers, caterpillars? The thrushes will exterminate them if you give them the chance.

Swallows? Sky-birds, all, and great fly-catchers. What has become of the old-time barn-swallow? We still have mud and barns. Only seven species of the swallow family in the United States and six of these east of the Mississippi River. Since we have painted under the eaves of our barns, 
made them entrance proof to the birds, and made war on birds generally, the swallows have sometimes failed to reach us and are becoming rare. But these birds have the record as the chief natural enemy of the cotton-boll weevil. The great enemy of any of our seven species is the English sparrow, a useless, ratty bird that should be exterminated. Before the English bird was introduced into the country, and for some thirty years after, we had our own American swallows. Don't shoot the wrong bird.

I will give some little evidence in favor of the English sparrow. Of several bird-houses I set up, the English sparrows took possession; the houses were compartment houses, accommodating about ten families each. Soon after I set them up,- - one was fastened to the telephone pole,-a wandering flock of bluebirds arrived, about 7 o'clock, one September morning. They were spying out the land, and dozens of them inspected the new quarters, with seeming intention of engaging them for the next summer. My expectations were high. The next summer one pair of the bluebirds returned and leased a smaller house set up over the arbor. Here they raised their family in safety, and at the expiration of the lease, moved out. Jenny Wren had been eying the apartment all summer, and had taken an adjoining house at the other end of the arbor, but for some reason, she was unhappy; perhaps she did not like Quaker drab, in which the apartment was painted. But 
no sooner had the bluebirds removed, than Jenny, with a twitter and unconcealed joy, rushed into the bluebirds' late quarters and began hauling out the nest, scattering it to the four winds and singing at the top of her voice all the time. Having cleaned the place out, she too departed. The English sparrows had taken possession of two houses, and as their numbers seemed at least obtrusive, one of my household suddenly tore out the rude nests they had made hoping to drive the birds away, and one of the houses was taken down for a time. On the next telephone pole, some distance away, I had fastened yet another compartment house, somewhat larger than the others. The English swallows promptly took possession of this for the remainder of the summer. We called it "the slums." One pair of the British birds built a nest in the open eaves of the north porch, and there raised two lusty broods, whose shrieks for worms could be heard way down in the cherry orchard. I noticed that these English sparrows fed on insects, worms, grubs, and the like, just like robins, quite losing their habits of playing street scavengers. Robins, wrens, bluebirds, flickers, woodpeckers, king-birds, seemed ever quarrelling among themselves, but I did not observe that the English sparrows either gave or received blows. Perhaps it is better to have English sparrows than no birds at all.

Orioles, blue jays, sparrows? The sparrow family is said to comprise more than one-seventh 
of all the birds in America. They are plain, homely, noisy, sociable creatures, chiefly feeding on the seeds of weeds. A single tree-sparrow is said to consume one ounce of weed-seed a day. This means, in a State as large as Pennsylvania, the consumption of more than six hundred and fifty tons of weed-seed each year by the treesparrow alone, and there are many other varieties of this active family in the Commonwealth. Shall we kill sparrows and raise weeds, or kill weeds by protecting the sparrows? The blue jay is always after the brown-tail moth, the extent of whose ravages cannot be estimated in money. The blue jay is Nature's specific for this most destructive moth. Which shall we have, fruit trees, shade trees, and the blue jay, or no blue jay and no trees? But there are animals that wear trousers and carry guns who-? and after the gun,- - a dead blue jay! Bobolinks? Down South the rice-planters condemn them; up North, away from the rice-fields, the bird develops an insatiable appetite for all sorts of harmful insects. Here at the North we must say, "Let somebody else kill the bobolink; we need him."

Crows? Yes, a good friend, the crow. Grasshoppers, cutworms, meadow-mice, countless numbers of these do the crows destroy. After a very careful hearing, and the jury out a long time-out indeed for years, - the verdict, as reported by Uncle Sam, in the celebrated case of "The People of the United States vs. the Crow," is: "The 
destruction of crows is mistaken policy, for the crow performs important services to agriculture, and his extermination would be a loss to the country."

House wren, phœbe, martin? We used to have these cheery policemen about our houses in great numbers, but the English sparrows-so it is believed-have quite driven them away. But whither have they driven them? The British birds did not eat them. I strongly suspect that the boy and the cat and the man and the gun and the English sparrows may account for the suspicious absence of these old friends. But if you really believe that the British brown-coats did it, then fire away at the brown-coats, perhaps after reading that comforting pamphlet published by our Government at Washington, on "The English Sparrow as a Pest." Possibly as the British birds are now very numerous we have here the way out in our demand for something to kill. Boy and man thirst to kill something, and here are the English sparrows. If perchance in killing them you save robins, crows, flickers, mourning-doves, woodpeckers, cherrybirds, owls, quail, orioles, grosbeaks, martins, bluebirds, let us by all means save robins, crows, doves, orioles, and the rest. But I may, I must, submit another morsel of testimony which may temper wrath against the English sparrow. At the corner of the east porch, amidst the vine, a Virginia Creeper, - a chippet

I United States Year-book of Agriculture, 1907, p. 170. 


\section{6}

\section{An American Fruit-Farm}

built its nest and brought forth four young. The parent birds were tame, coming to the nest constantly with supplies; even alighting on our persons as we sat near by. One afternoon I noticed three birds feeding the brood, but being doubtful, I summoned witnesses from the household. We all agreed that the old birds had a helper. We noticed that when she came, the birdlets were still as mice, nor made one peep till long after the "neighbor" had gone. It was an English sparrow that was helping and that continued to help till the last chippet had flown from the nest. Whether some mourning widow, or officious neighbor,the "slums" were quite a distance away,-or whether the chippets, feeling that they had too large a contract on hand, had employed a day nurse we never knew. Every fruit-farm should be a bird-sanctuary. 


\section{$\mathrm{X}$ \\ THE FRUIT-FARM AND OLD AGE}

WISDOM, serenity, - and, Macbeth adds, "honor, love, obedience, troops of friends," should accompany old age, yet such a galaxy we rarely see. Youth has slight idea of time; age has no other. To youth, age is a port so remote that the voyageur thinks, "Time enough for that; it is not yet on my chart"; to age, youth has begun a voyage so devious, it is idle to presume to mark it out. Youth is hope, age is memory; youth attracts, age repels. The prince is waiting for the kingdom; the heir, for the estate. "Who would have thought the old man to have had so much blood in him!" exclaims Lady Macbeth. "Who would have thought the old man would live so long!" exclaims the son whose life has been only an expense account to his father, who gave more thought to his fruitfarm than to his boy. "Something for my old age," says the man in middle-life who has known the buffetings of fortune. The fear of want and dependence makes many a man in the Valley a fruit-farmer. The orchard and the vineyard are safety; a pension between the man and the poor- 
house. Land, Blackstone gravely informs us, is immovable, therefore the man fastens himself to the land in great hope, as men in shipwreck lash themselves to rafts and spars. Security in life is the pearl of great price;

\section{"Yet we all know security \\ Is mortals' chiefest enemy."}

Overland, in ox-carts in summer, overlake, in sleds in winter, from New England and New York came that stalwart band some of whose descendants remain in the Valley to this day; but most of the land taken up by the pioneers is now in the hands of strangers. Many of those who first cleared forests and left fields grew old, and fell asleep in the Valley, but some, restless as the sea, pioneers to the heart of their hearts, like Daniel Boone, felt stifled if they saw the smoke from a distant hearth, and, leaving their little clearing, sought the prairies of further Ohio, Illinois, Indiana, or the rich lands of Michigan, and some passed far beyond the Great River, even to California, swelling the company of the Argonauts of '49. But they who remained in the Valley and grew old among their fields of corn and wheat, their flocks of sheep and cattle, watched the world roll past their doors and part of it roll back again. These were the fathers of the Valley who built roads and bridges, churches and schools, and at last, forsaking their log-cabins, built fine and yet finer houses for themselves and for their children, 


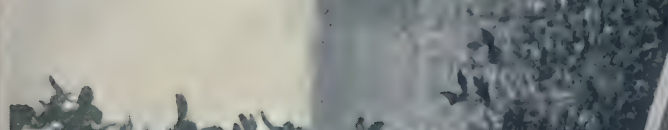

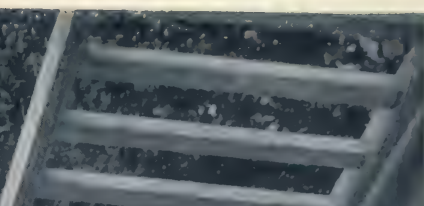

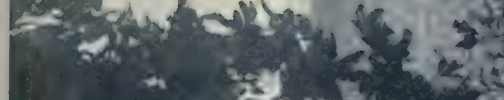

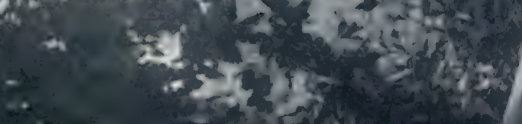

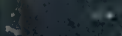
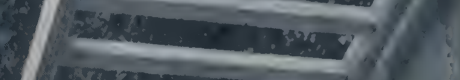

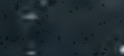

in $x^{2}+2 y+x+2 y$

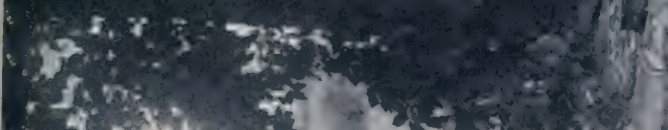

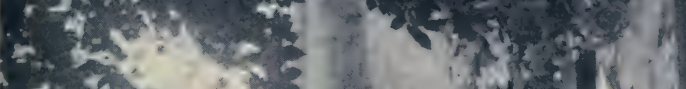

stists

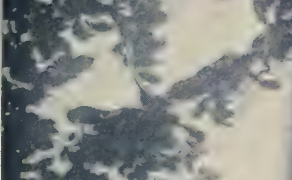

$20^{2}+x^{2}+2$

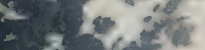

$9 \ln \left(\mathrm{c}^{2}\right.$

tot d

"set

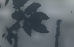
Iat

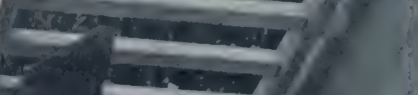

.

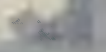

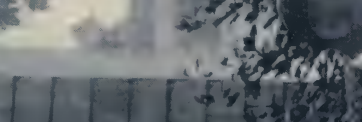
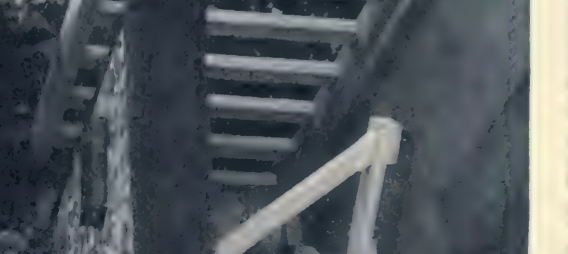

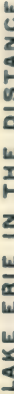
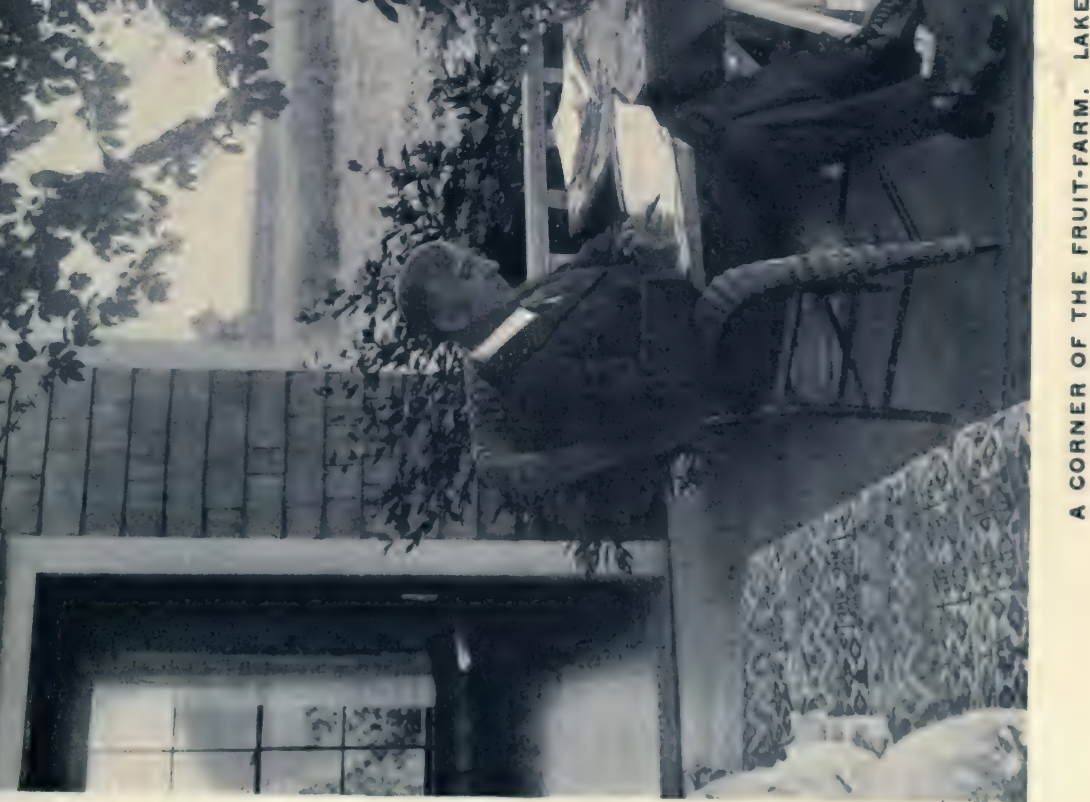

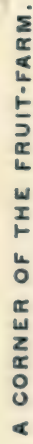



and, dying, gave each child an ample portion of their ample estates. They were the elders, the deacons, the 'squires, the colonels of their day: large, vigorous men, who did things in a large way, and thought little of overcoming difficulties. They were of the builders of the nation.

Most grandfathers and all great-grandfathers are heroes to their posterity,-Homeric personages in the history of the family, - and all more ancient ancestors "were giants in those days." This exaltation of ancestors was the religion of the classic world and remains in much of the religion of to-day. To have the right to carry busts of ancestors in the funeral procession marked the divine origin of the dead Roman and his living descendants. We in the Valley do not carry such tokens of divinity on our way to the grave, but we enjoy any knowledge we think we possess of being fruit of a very ancient tree whose roots run deep into European soil. Between Adam and the Flood few of us find difficulty in tracing descent, but grave embarrassments arise between the Flood and the American Revolution. Happily for all men - and of course this includes us within the American Fruit Valley, -when Nature fails, man bravely steps in: there are nurseries in which genealogical trees of any variety may be had, each of its kind, and we may add, of its price. But in the days of pioneering the fruit-trees in the Valley were not from genealogical nurseries; rather did they come from the wild. 
These pioneers did a greater work than Hercules: they planted the seeds of a civilization which bears fruit unto this day. They found the Valley as La Salle, Celeron, and Father Hennepin saw it, and began the transformation that is going on to this day. The Valley as we see it was not made in a day. We have cleared away remainders and vestiges of the primeval woods; we have drained wet places, built roads, houses, and barns; we have changed pasture lands to wheat fields, wheat fields into orchards and vineyards, and where yesterday the wild deer was speeding like the wind, to-day is a sweep of cherry blossoms. This we did with cunning tools and help of many hands; that they did with slow and painful toil, grubbing through the tall, thick woods, burning the forest to get rid of it, and paying for their land with the pearl-ash which they hauled in mid-winter, over a wilderness road to Pittsburgh or to Barcelona, where, getting a few pieces of silver they made their titles secure. And one acre of this land which they cleared with such lengthening toil is to-day worth, as the world says, more than a thousand acres of the days of pioneering. They labored and we enjoy; they toiled for us who come more than a century after. Their age was our youth; they built the ship and began the voyage, and we are making port.

Generations to come will speak of our labor as vast, astonishing, Herculean, and will carry our busts in their funeral processions. Yet in the Valley-possibly in other valleys-few old men 
now living were born on the land they now own. Land tends to become more and more an article of commerce, a utensil, a bale of silk, a yard of calico, and so changes hands easily. So frequent is the change, the land has slight chance of being a birthplace. It takes time to be born as well as to die and land must be in the family long enough for the event to happen. The pioneers in the Valley took time for life; the Valley was their home and they looked for no other; they had gone West, and the Valley was West. Their dreams were of New York and New England, but these hills and this lake were before their eyes. A man lives in his visions, though they hover over a distant sky line and under strange stars.

\section{"His heart 's in the Highlands, His heart is not here; His heart 's in the Highlands, A-chasing the deer."}

How-busy-soever he may seem to be in the Lowlands, he lives in the Highlands. Within this round $O$ which encircles orchards and vineyards, hills and lake, gleaming streams, field and forest, the pioneers lived and saw visions and here they are buried.

I remember, years ago, the burial of one of these pioneers who for more than half a century had lived in an old-fashioned house amidst orchard boughs. The logs had been covered more than seventy years since with thin, wide clapboards 
and the winds and the weather had painted them a soft gray. An ancient grapevine ran the whole house around, close to the eaves, and tiger-lilies, snowballs, pinks, and lilacs were a wilderness. The bubbling spring near the door was partly covered by a broad, flat stone, and a well-trodden path led to it. Within doors the great beams stood exposed; the wide floors were uneven and the windows had diamond panes and were overshadowed by the vine. There was a cavernous woodshed, and the swallows twittering in and out; and some were diving into the throat of the huge chimney at the gable. Under the rude cornice ran the irregular line of mud nests, and the roofs were green with moss. Thither the pioneer had come in his youth and made his home. Here he had brought his bride, and here the children were born. They had all gone out into the world, leaving the old folks alone. On Thanksgiving Day some of them would come back to the family reunion, and then the long waiting till another Thanksgiving Day. The burial of the pioneer was on a peaceful June day, not rare in the Valley. All the world was in bloom. It had been a peaceful ending of a peaceful life. There was the touch of silence in the orchards, the hint of loneliness in the air; so silent that, as we stood among the lilacs and the pinks, we could hear the ticking of the tall clock in the great kitchen, near the settle. We were for a moment in an age that has passed away. The whistle of the distant train seemed a painful, a wanton intrusion. Troops 
of friends were gathered about, and among them, the last of the pioneers who had assembled to bury their own. It was a closing scene in the play. The house was old; the trees were old; the lilacs, the smoke-bush, the lily beds, the grapevine wreathing the house, the faces set in retrospection, -all, all were old. Youth and modernity seemed an intrusion. The venerable dead had spent a long life here, slowly growing old and, at last, slipping away peacefully.

Strangers now possess the land; the house, abandoned, fell into decay. The spring is choked; the old-fashioned flowers have vanished; the very site of the old home is a cornfield. The children or the grandchildren never return; all the neighbors are strangers and even the memories of the old home are forgotten. Yet for nearly fourscore years it was the old home, and the pioneer who transformed the wild came to the ideal old age accompanied by "honor, love, obedience, and troops of friends." But the children abandoned the old home; yes, but that is quite another story, a story which the old pioneer himself did not write; every man is author of his own; he could not write theirs, and they cannot write his. The son of this venerable pioneer died suddenly of heart-failure, a prosperous banker, having attained the great age of fifty-three; indeed, he was older than his father dying at eighty-eight. The pioneer had arteries which kept young.

But every fruit-grower does not reach eight and 
eighty, nor does every city banker die at fiftythree. The problem is to keep your arteries young. Some say. "Eat cheese"; others, "Drink sour milk"; others, "Buttermilk"; "Don't worry"; "Sleep on the roof"; "Two meals a day"; "Avoid extremes"; and yet others, "Farm." Old age and crafty death, as Whitman tells us, pursue, overtake, overcome all,-so why seek to escape! Let us be patient, and, like Seneca, receive the messenger calmly. For be it bank or farm, factory or the high seas that we affect, we yield at last to the enemy. It is the living, then, not the dying, that concerns us.

What has the fruit-farm to offer for daily living? Nothing, unless your heart is in the fruit-farm. Orchards and vines may mean life to me, but daily death to you. You pine for city ways and scenes, for these are life to you. Length of years is found not exclusively in city or country; old age may be found in either. But length of years is not living. Lincoln at fifty-six had done more than old Parr at one hundred and fifty-two, or, so far as we know, more than Methuselah at nine hundred and sixtynine. Cæsar, Napoleon, dying at Lincoln's age, accomplished more than all the centenarians of their time. Alexander at thirty undoubtedly had done more than any other youth of man and woman born. Life cannot be measured by the calendar. At Tivoli we are shown vestiges of the summerhomes of Horace, of Cæsar, of Brutus, of Cassius, but the world finds these men in Rome. We must 


\section{The Fruit-Farm and Old Age}

locate a man more definitely than merely by saying, "He lived on the planet somewhere." The region of a man's essential activities is ever small, Alexander, Cæsar, Napoleon, and the conquerors astonish us by the extent of their triumphs, for their influence reaches us also. But there are other, even mightier conquerors, not men on horseback, spear and sword in hand, war and ambition in their hearts, but peace and good will, and life and living. The Cæesars are the exceptions and the world exalts them as the measure of a man. As ridiculous to measure the mouse by the elephant as Napoleon by a huckster, or Lincoln by a street-juggler. Each after his kind is the law of youth and age. Unless common men abound to admire, then it were foolish in Cæsar to be ambitious. No man cares to smoke in the dark; and were we all fishes in Mammoth Cave, what use had we for eyes? What would become of costumiers were men blind? How much is the world governed because of "looks"? Youth is commonly misled by exceptions, and many a man never outgrows his youth. It is a wise man who knows, believes, labors, lives with no thought of Cæsar. Our schools and colleges have much to answer for, in their diversion of youth from reasonable ways by deluding them in knowledge of Alexander, Napoleon, Rockefeller, Shakespeare, Lincoln, Marconi, and others, the exceptions among men. The young man is fired by the illusion that, having had explained to him the activities of men of might, 
the rare and exceptional spirits who at intervals of long centuries visit this earth, they can do as the mighty have done, or, unable to do, shall live miserable ever after. Inspiration is not imitation; its coals of fire are original. The old pioneer, dying in his home, amidst the work of his hands for quite fourscore years, has done his work as well, in its kind, as did the foremost man of all this world. Let there be a hundred elements in the visible universe, one is as important as another, so far as we know; radium is no more important than nitrogen. Be there a million trees in the forest, so far as we know one tree is as important as another. The most popular notion abroad in America, "All men are created equal," might seem to hint that the fruit-farmer is as important as the President, so far as we know, and that

"Each thing in its place is best, And what seems but idle show Strengthens and supports the rest."

True, Shakespeare does not sing the equality of men; nor does Plato, nor Aristotle, Zeno, Cicero, Bacon, nor Spencer. Grotius affirmed the equality of sovereigns, and Rousseau and Jefferson straightway carried it over among men of all sorts and conditions. Equality is the most popular doctrine the world has ever known. True or false, this doctrine must now and forever be reckoned with. All shades of interpretation of the doctrine have been made, and they agree that the man him- 
self, not man as a kind of animal among animals, is the principal element. To the man all comes at last. The living of one man is as much to him as the living to another, whether acreage be small or vast, or the menu be bread and cheese or of nineteen courses. The fruit-grower is as much to the fruit-grower as is the banker to the banker. Threescore and ten years on the fruit-farm in the Valley mean as much to him who lived them as three score and ten years in the bank, or in practicing law or medicine to him who lived them.

Does it follow, then, that as all fruit-growers do not die centenarians fruit-growing is a risky business? Does the making and the care of orchards and vineyards keep the arteries young? Or do stock-raising, wheat-farming, or "a few acres and a cow"? If a man would have young arteries he must select young arteries to be born from,- - not merely young arteries, but arteries that keep young. One cannot put new arteries into old bodies. The flight of time is not stayed by a man's taking title to a fruit-farm. But in bringing up a cherry tree in the way it should go, a man also determines the state of his arteries. Ancestors here play their part; indeed, they really determine all the important lines for their posterity. Next to ancestors come the man and his habits, or, say, his bundle of habits, - which is the man, - and next to the man the orchard and the vine. Of these habits thinking is most tyrannical, for he is as he thinks. There is an imperfect translation of this line,- 
"As a man eats so is he." One must be careful in his translations. The habits of ancestors become arteries on the fruit-farm. It might seem that a man might know as much as a bird and eat what will agree with him; or, like a plant, assimilate only food and flourish. Animals feed as they live, by instinct. If the fruit-grower's instincts are normal, will his arteries keep young? This too depends upon the man. If he enjoys life on the fruit-farm; if he lives in his trees and his vines, wise, serene, amidst troops of friends, summer, winter, spring, and autumn, storm and sunshine, he will find his arteries in the fruit-farm, as young as he makes them. Where his vision rises there it rests. The Valley is his country; its hills bar away the world; its lake divides him from a foreign land. He sits beneath his own vine and cherry tree, hears of wars and rumors of wars, but the Valley is peace. He has his anxieties, supreme at the moment, trifling when past. $\mathrm{He}$ feels himself anchored to safety-his fertile acres. The fear of want he never knows. Nor indeed if he is a thinking man, does he sigh for impossible riches, for he can never obtain wealth beyond the limits of the business he is in. Wealth is the profit on labor; the more the laborers, the greater the wealth. Oil kings profit by everybody's labor; so too the steel-kings, the cotton-kings, the beefkings, and all other kings who monopolize the activities of countless thousands of workers. The seamstress, working by the midnight lamp, en- 
riches the oil-king, as does the ocean-liner, or the dreadnought whose black smoke breathes of burning petroleum. But the fruit-grower can have no like monopoly of labor.

If he is laboring for great riches, he is hardening his arteries in vain. Now the struggle for riches is the chief hardener of arteries in any vocation; it is the fatal habit. Not infrequently such hardening of the arteries occurs early in life, and few who drive fast and furious in chase of wealth survive threescore. The precise date is fifty-six; why so fatal I do not know. But necrology tells this perpetual story. Even fruit-growers cease at fifty-six, or younger, if they have quite solidified their hearts, to say nothing of their arteries, by striving for riches.

Honor, wisdom, love, obedience, troops of friends, distinguish old age, yet we have known aged persons distinguished by other qualities and possessions. We have known old men not wise, but foolish; not serene, but restless; not surrounded by troops of friends, but with difficulty attended by a hired nurse. Even in the Valley, years do not always bring the philosophic mind. The reason is plain: few men are philosophers; few at any time are wise, at all times serene, or ever attended by troops of friends. Old men are precisely what they have made themselves. The vocation does not change the man. A querulous youth becomes a querulous old man, unless he undergoes a process of elimination. Peach trees cannot do it for him, nor 
grapevines. The fruit-grower may make a tree fruitful and miss being fruitful himself. There is a hint of serenity in an October tree, weighed down with golden fruit; there is a hint of troops of friends in the apple tree in full bloom, the bees humming among the branches. There is a hint of wisdom in the fruit-farm well-placed, well-made, well-tended, trees and vines shining in vigor.

But every plant has its enemies: insects, fungi, beating sleet, crushing winds; it is attacked in earth and air, in bud and blossom, in leaf and fruit, bark, twig, and root. The wonder is it survives. Perhaps, could we see our own race as we see plants, we would wonder that there is a human being left on the earth. That the race survives is the miracle of life,-whether of plant or animal.

Does the fruit-farmer care for himself as well as he cares for his vines and trees? Here is the supreme question, and the answer is the man himself. He too fades as a leaf, but next year the leaves burst forth afresh. The tree too runs its cycle; it falls to earth again to become part of the soil and food for later generations of its kind. The question of questions is, "If a man die shall he live again?" "As the tree falls, shall it lie so?" The one we answer in faith and hope; the other Nature answers before our eyes and in our own experience. If there be any difference between the tree and the man, it is thinking that makes it so. Of what then can the fruitfarmer think? Of grapes, cherries, peaches, only? or of himself? And not of himself solely but of 
himself in human relations-those relations which Shakespeare tells us mark green old age, "love, honor, obedience, troops of friends." We come then by way of orchard and vine to the man himself, having long since passed the cherry tree. That is hanging full of scarlet balls amidst the green, fine product of Nature's craft. Is he also fruitful, a spirit abounding in the humanities? Is he symbolized in his cherry tree?

A very mean man may raise very fine cherries,sweet cherries, not English Morellos,-and a very good man may have no cherries on his trees, not even Morellos. There lived, long years ago, in the Valley a valiant pioneer named James Smedley, a Yale man of the old type, a medical son of Eli. He was always eloquent of temperance. "But, Doctor," said Halsey Taylor to him one day, the hot sun streaming down upon them in the barley field, "how is it that you, who are so strong a temperance man, raise so much barley?"

"Why, young man, reason enough! Reason enough! I raise barley for seed!"

In the search for old age one is not compelled to travel by way of a fruit-farm; he may reach it by any route, anywhere; indeed, give him time, and he cannot miss it. There are routes and routes. Were he to choose, which would he take? Did fruit-growing lead to perpetual youth, all the world would be fruit-growers. It is accident, promise, volition, profit, each and all which lead him over the route. When we consider the perils he will 
risk, it would seem that the supreme determinant is the hope of gain. Hasten not to be rich. $\mathrm{He}$ is foolish who heaps up riches, for he does not know who shall scatter them. The life is more than meat. The lilies are clothed more gorgeously than was Solomon in all his glory: ancient sayings, all and doubtless true, once, in very ancient times, but not in these days of peril and struggle for existence! In the Valley these sayings have been current-at least on Sundays-for more than a hundred years. Fruit-growers have heaped up savings only to be scattered by strangers, or wasted by the children for whom they were so painfully saved. Easy come, easy go, is the law of the Valley. To appreciate a fruit-farm, one must make it out of the sweat of his brow. Cost nothing, worth nothing. Build the house a little at a time as you prosper and it becomes a temple; if an inheritance, a gift without associations, it means no more to you than a freight-car. The less you have in the house, the more boldly you tear it to pieces; and the more you change it, the more it is yours.

The fruit-farm is the embodiment of threescore and ten years' labor; it resembles the owner. When it is a living memory it attains its highest value in his eyes. Having lived a lifetime among its trees and vines, he has reformed it many times, so that like a chain it lies in links of construction, and each link is a period of life. Here age reads its diary and every bush and tree is a memory. Here 
Annie lost her ring; there Bob caught the rabbit; yonder is what is left of the old deer path; this is an Indian spring; that row of apple trees I planted the year the war opened, and this cherry tree by the porch I sent home in a letter from near Fredericksburg, before the battle. Mother planted it. We never thought it would live. When I got out of the hospital it perked up and began to grow. We always called it "General Hooker," and a fine tree it is, - when it bears. These grapes I raised from the cuttings and I cut the posts and stakes myself when we cleared the piece of timber east of the grove. What? Why that is my Washington peach. Colonel McLane gave it to me while he was in Congress; he brought it from Mt. Vernon. And so the old man goes on from tree to tree, vine to vine, over the whole farm, associating everything with some tender memory. The whole farm is a bundle of associations, - not yours, nor Annie's, nor Robert's, but his. It is his world. There comes a time when a man's thoughts return to the scenes of his youth; the fruit-farm is the scenery of a long life.

I have known young people in the Valley who furnished their house, when they started life together, with antique furniture - anything old would do. Most of the equipment they purchased at one blow in an antique shop in Salem that is skillful in giving the hundred-year touch to the product of the shop in the back-yard. The zeal for association may become a passion; some people 
care nothing for their great-grandmother, but they would like to have her silver spoons; others pay liberally for anybody's old table. Some like to think, as they sit at the Chippendale desk: "Here my father wrote; and his father, and his father's father." There is the nice suggestion of continuity and a dim impulse toward ancestorworship, - a sort of return to first things. Who does not make a more cautious bid or play a better game if the card table came over in the Mayflower?

The man who has grown old on his fruit-farm lives in daily communion with an unseen worldhis yesterdays; and no man's life is so interesting to him as his own. "Leave the old farm?" he answers when some one would buy - "Yes, when I leave the world!" "Leave the farm?" says the heir, to whom it is only bushes and bother-"Well, you just offer me a price and see!" He parts with his inheritance like Esau. No man willingly sells his life, and associations are life. The stranger cannot buy them; the heirs cannot sell them, because they were never theirs. Even the old man cannot part with them, for they are he himself.

At the Pennsylvania Historical Society in Philadelphia there is a death mask of Napoleon. Not many years ago an aged man might have been seen on the eighteenth of June, standing, hat in hand, gazing reverently upon the mask. It was George Nieman, private secretary to Blücher, during the hundred days. He fought at Waterloo; he captured the iron carriage used by the Emperor 
and now displayed at Madam Tussaud's; and he kept a diary of his hundred days. Translated, it was published in the English Historical Review. Most interesting its incidents. At the grand charge of the Imperial Guard under Ney, Blücher's horse was shot and the old General was pinned to the earth beneath him. Nieman threw his own cloak over the prostrate General and the French surged over him, never suspecting, and Blücher was unharmed. "Now," so runs the journal, describing events before the battle of Ligny, "we had Napoleon before us and he was equal to an army of 30,000 men." Once a year the aged man came to the rooms of the Society. The Librarian would open the doors of the iron closet, take out the death mask and, retiring, leave it for the veteran of Waterloo to gaze on. Not a word would he speak. Silently he lived again his hundred days. Again he witnessed the charge. Again he was at $\mathrm{La}$ Haye Sainte and Wellington and Blücher were grasping hands. Again he was entering Paris with the Allies and the five Kings, and again he was with them at the grand opera. To me who translated and published the veteran's diary, this death mask meant only a name; a day spent on the field of Waterloo; an autograph, a book, and petty relics of the exiled Emperor; but to the aged German Lieutenant it meant the most dramatic experiences of a lifetime. It was his supreme association.

To the man who for many years has lived 
amidst orchards and vineyards, they become like the mask of Napoleon to the veteran of Waterloo. That great event was his event, his victory. So these trees, these vines, this equipment for living in the Fruit Valley becomes the old man's great event,- - his victory. Scant enough is the consideration given to old age to-day. Even in the Fruit Valley, where life moves with even and prosperous current, the aged seem to the young somewhat an encumbrance. Commercial greed has penetrated the Valley and the young are impatient to possess the land. Nor is age unconscious of this. It feels the chill, not of years alone, but of greed and discourtesy. Children and youth are now the supreme rulers, and for them and them alone the world exists. The restlessness of mere bodily motion, the intoxication of mere diversion, are the cravings of the hour. "More money and more fun!" is the cry. Life is a cheap, boisterous merry-go-round; a perpetual sojourn in Vanity Fair. Old age is not senility if only it can hold a hand at bridge. But youth insists on being in at the making of the will. "Give me my portion of goods!" it cries. The orchard, the vineyard, the cherry tree mother planted, the apple orchard father set out, are only money-makers, not beautiful plants which living hands set out and loving hearts tended many, many years and made precious by thought and toil. There is only one book in the world-the cashbook; only one account-the bank-account. Old 
age, even when rich, is a burden on the family, and penniless old age is a nuisance which the public must abate. The children fly out into the world; father and mother are sent to the poorhouse; they committed the unpardonable offense of being poor and growing old.

In the Valley, if men are young at sixty, they are also old at thirty. Boys and girls at eighteen have lost the bloom of youth. Commercialism drives the schoolgirl into an office to pound away her life on a typewriter, and to the end of her days the atmosphere of that office hangs about her. There is the inestimable loss of femininity which she can never make up. The boy plunges into the world at eighteen and is gray, wrinkled, and sordid at thirty. He is older than his grandfather, and has learned lessons which the orchard and the vine never teach. Between the young people and the old there is a great gulf fixed and neither can-even would he-pass over to the other. The boys and girls are like peaches trigged out in market with fancy paper covers in natty baskets, but we know that the bloom has been rubbed off and that the fruit is stale. And we decline further disappointment by not searching to the bottom of the basket. But somebody buys the peaches,possibly on a bargain counter. As we wander through the stalls, we are thinking of the days when we picked real peaches from real trees, each after its kind.

Nature always has her winnings at the end of the 


\section{An American Fruit-Farm}

game. Cheat her and we cheat ourselves; play fair with her and she rewards us bountifully. Forget to feed the peach tree and Nature forgets to put any bloom on the peaches. In vain we deck the branches with bits of glass and colored paper; quality and bloom are not. Forget to feed the boys and girls and Nature forgets to beautify them with the indescribable charm and bloom of youth. The shoemaker makes shoes, not children's feet; the milliner makes clothes, not girls' bodies. Nor can factory and physician together take the place of Nature.

Even young fruit-growers go to Carlsbad to drink the waters at the hotels. Grandfather drank from the Indian spring on the farm, but he missed Baden Baden. Is life a fable agreed upon? A product of the factory? A creation of the Patent Office? In days not so long since past it took seventy years to make a man old. We do it in half the time now, in the Valley,-perhaps in other valleys. Then it took a week to reach New York; now half a day. Then it took seven years to learn a trade; now no time: men are born mechanics and resume practice without notice. Then one man worked for another for wage agreed upon between them; now he refuses to work, but demands the wages. Then butter was eleven cents a pound; now it is sixty, and, like a cheap piano, "assembled" in a factory. Then schools were few and learning was desired; now schools are many, nobody studies, and all get a degree. Then 
men worked for a living, now the best player has the largest salary. Then children were seen, not heard; now children only are heard and seen. Then old age was venerable; now, like Mrs. Skewton, it is made up for the day, often falling to pieces if jarred. Then sermons were an hour long; now they are a bore of fifteen minutes, and in summer in the best churches both sermon and preacher are omitted. Then the father was the head of the house; now it is the cook. Then men and women grew old among their orchards and their vines and were reverently gathered to their fathers by their children; now the undertaker buries them by electricity and the children telegraph: "Regrets, previous engagement, but send copy of the will by return mail, please." Then the old faith; now the new doubt: ever saving then; ever spending now: paying for the farm then; mortgaging the farm now: old and young struggling to build the home then; now the young folks living in apartments, and the old folks all alone on the farm. But it is the same old world; only the folks are the latest novelty. Ours is ancient Athens in modern dress: all spending their time in hearing some new thing. That the world is fixed in its ways no one can doubt, and fruit-growers cannot change them. We come ever to the man at last. He grows old despite orchards and vines, but gracefully, with them. He fades as a leaf, but the leaf has grown to perfection during its life of a season. It has kept its cycle. Much has been written as to man's 
natural vocation. Hunting? Fishing? Grazing? Farming? Bartering? Fighting? Commerce? Science? Law? Medicine? Engineering? Writing? Is it anything? Is man by nature a fruitgrower? In the old days of pioneering, his supreme function, in the Valley, was clearly stated by the answer to the first question in the Westminster Catechism. Then the chief end of man was "to glorify God and enjoy him forever." In the Valley now, quite all that is left of the direction is "to enjoy!" Indeed, to-day a heaven without a Midway Plaisance would be no heaven at all. Then, a heaven with pleasure would have been an embarrassing surprise. If there is the old earth there is also the new heaven. Each generation sees its own earth and conceives its own heaven. The children in the Valley to-day do not see with the eyes of pioneers. Could those worthies return to the Valley, - - or possibly to other valleys, - they would not, they could not, see their world. Long as the oldest of them lived,- -and I remember two centenarians,- they witnessed only the strangeness of change; the faculty of adjustment had wholly failed them. This is growing old,-the increasing feebleness of adjustment. Perfect adjustment means immortality. The aged man may have managed to adjust himself to new conditions for many years, when suddenly his power ceases; his collapse may be wholly physical; his mind is still attuned to the rhythm of men and things. Here is the cue to old age, a sound mind 
in a sound body; even a sound mind in an unsound body. It is not the most powerful mind in the most powerful body, but simply the sound mind responsive to Nature till the end. Not Plato's mind, for that was his alone; nor Samson's body, for that was Samson's. But your mind in your body, in your world. Perhaps your world is the Fruit Valley; mere locality makes no essential difference. I am thinking of men and women who grow old fruitfully,-performing their functions till the close of life's last day, each after its kind. For every man has a natural life, if he but knows, and his supreme function is to live that life. Is it to be old at thirty or at eighty? Is it to use up the springs of mind and body while yet in the dew of youth?

The uselessness of old age and the indifference towards it, to-day, in the Fruit Valley, -and possibly in other valleys, - are the natural result of ways of living. Old age reaps what it sows. Did the pioneer labor for meat and raiment only? Was yesterday's thought in the Valley to have greater riches to-day? Where else in the world are such wonderful gardens, flowers, walks, vistas, as at Monte Carlo? And there are other things at Monte Carlo also. Some of these are not shown. They are not even reported. They are buried in haste.

Youth to-day is the product of yesterday. The fathers labored for riches and many of them quite forgot, the while, for whom they were toiling. Neglected children attract less attention than 
neglected orchards and vineyards. We hear of "the run-down farm," not of the "run-down" son or daughter of the farmer. We hoe the garden industriously and let the children and even ourselves run to weeds. And then, when the boy and the man, the girl and the woman are choked by the weeds, youth is old and broken before its time, and old age has not "love, obedience, and troops of friends."

"My orchard runs to apples," said one fruitgrower to another, in the Valley, one morning, a touch of contempt in his voice; "And mine," replied his neighbor, "runs to boys." Paradoxical as it may seem, the object of a fruit-farm is not to raise apples, grapes, peaches, berries, or cherries, but boys and girls, men and women, youth and old age. He has the best fruit-farm who raises the best fruit. When, at last, come Old Age and crafty Death, as surely they will come, by its fruit the fruit-farm and the farmer are known. It is not his bankaccount but his boy that is the real asset or liability of his life. Here cluster all associations; here center all memories. The men and the women who live for the children, just as robins live for young robins, have lived naturally. But the life is more than meat and the body than raiment. Wisdom is the principal thing and the best fruit-farming is understanding. Spreading orchards and rolling vineyards are fair to see and fruitful, but their real beauty and fruitfulness are in the use made of them. "Here a man grew!" marks the site of earth's great- 


\section{The Fruit-Farm and Old Age}

est, most famous places. Ancestor-worship, the most ancient religion of the race, is a product, an early product, of belief that a man is the finest fruit this planet can bear. The valley which produces the best men and women is the valley in which to live and die. Youth or age there is sacred. None too young, none too old for reverence. The price of living is above rubies. There the fruits of the earth grow to perfection, every tree and vine producing after its kind. One of the choicest, the rarest fruits of the Fruit Valley is Old Age, accompanied by "love, honor, obedience, and troops of friends." 



\section{INDEX}

\section{A}

Adam Bede, 26

Aneid, 25

Age of Fishes, 182, 192

Agricola, 25

Agricultural Colleges, 22, 24

Alaska, 196

Alsach (Alsike) clover, I40

America as fruit-producer, 126, 127

Ammonia, 204

Angelo, Michael, 25

Anthracnose, 108

Antiquary, the, 26

Appendicitis, 64

Apples, varieties, 87

Argonauts of ' 49,318

Aristotle, 214, 326

Ashes, 95, 184, 204

Atlantic City, 82

\section{B}

Babylon's Hanging Gardens, 59

Bacon, Sir Francis, 326

Bailey, Professor, cited, 208; quoted, 300

Barnyard manure, I40, 142, I49, $180,184,185,186,197,198$, 207, 266

Baskets and packages, 147

Beal, Dr., cited, 309

Beethoven, 25

Berries, 85, 86

Birds, and aliens, 303; and public schools, 283; bird-life, tide of, 296; bird sanctuary, 308, 316; blackbirds, 275; bobolinks, 3 I4; bulletins, 309, 315; cats, 298; chippet, 315, 316; consumption of insects by, 277, 307; crops, contents of, 305; crows, 314,
315; destruction of, 291, 293; doves, 315; English sparrow, 312, 315; extinction of, 294; game-wardens and, 304; in Italy, 300; jays, 313; Lane law, 272; martins, 315; orioles, 313 , 315; passenger pigeon, 293; phoebe, 315i pot-hunters and, 278,304 ; robins, $276,277,294$, 306; swallows, 3II; tanager, 276; thrushes, 3 IO, 3 II ; value of, 272-316; varieties, uses, 310; woodpeckers, 276, $3 \mathrm{II}$, 315; wren, 315; and see 272-316 Birds of a Maryland Farm, 309

Birds of California, 309

Blackberries, 108

Bluecher, 335

Bone, 202

Book-farming, I63, I65

Boone, Daniel, 318

Bordeaux, mixture, 156; tables, I60; see also under Spraying

Boys and the fruit-farm, 21I239, 338

British Columbia, 40

Bronze Age, 35

Bulletins for fruit-raising, 153 , I54; list of, 173

Bumper crops, 18

Burbank, Luther, cited, 24; 208

Buried seeds, 195

\section{C}

Caesar, 5I

California, 47, 126, 318

Canterbury Pilgrim, 14

Cato, cited, 12, 29, 58, 122; quoted, $40,166,167,210$

Cats, 278,298

Celeron, 320

Central America, 40 
Cervantes, $2 \mathbf{r}_{5}$

Chautauqua Fruit Belt, 42, 43

Cherries, diseases of, 157 ; pruning, 135; varieties, 94

Charlevoix, 45, 97

Cicero, 326

Clay land, 138

Climate, 33; belt, 36; importance of, 62, 209

Coal-measures, 192

Coddling-moth, 275

Concord grape (see Grapes)

Carboniferous Age, 42

Cornell University, 120

Cover-crop, 22, 143, 144, 145, 149

Cropping the land, 200, 232

Curculio, 156

Currants, 109

\section{D}

Darwin, Charles, 278

De Candolle collection, $2 \mathbf{I}$

Denonville, 45

Destruction by insects, 280; by scale, 282

Devonian Age, 42, 182

Dobbins, Captain, 240

Drainage, construction, 78, 79; importance, $77,85,189,248$, 249

Dry farming, 190

\section{E}

Earthworms, 278

Edison, 53

Employers' Liability Act, 129

Emerson, quoted, 26

English Historical Review, 335

Erie County, 45

Experimentaistationsand Schools, I 53, I64, I65, I87, 208, 235

\section{F}

Farm buildings, 260, 26I

Farm management, 25

Farm valuation, 288, 289, 290

Fertilizing, 19, 20, 183, 197, 202; tables, 204, 205, 206, 207, 248

Florida, 47, 126

Florida rock, 202
Franklin (Poor Richard), cited, 215; quoted, 56, 213

Fruit, quality desired, I31, I35

Fruit-farm, a clock, I4; accessibility, 67; associations, 8 , 11, 317-343; care of, 57 ; cultivation of, 131-174, 255; enemies of, 152, 153; planning the, 7I-II2, $30,31,72$, II I; scarcity value of, I2; selecting the, 33-70; supreme rule of, 5

Fruit-farmer, and the boy, 220228, 342; and birds (see Birds); the model, 240-27I; and his farm, $68,69,317-343$

Fruit, nature of, 192

Fruit-raising, artificial, 54, 55; process, 60; quality, 147; secret of, 250, 255; (see "Neville Farm")

Fungi (see also Birds, Insects, Scale, Spraying), 4I, 75, 9I, I0I, I08, I50, I5I, I52, I53, I $54,156, I_{58}, 161,230,242$

G

Gage's Gulf, I 82

Garden of Eden, 215

Girls and the fruit-farm, 2 I I -239 , 338

Glacial Period, 65

Gooseberries, 109

Grapes, 95-I05; trimming, I38; diseases, I 58; roots, I4I

Great American Desert, 97

Griffon, the, 45

Guano, 204

Gypsy-moth, 275

H

Hamlet, 51

Hardpan, $\mathbf{1} 88$

Harrison, Fairfax, 4I, note

Hedges, 265

Help (see Labor)

Hennepin, 45, 320

Hog's Back, the, 97, 182

Homer, 21, 25

Hull House, 54

Humus (see Fertilizer, Soil), I7, 22, I4I, I 43, I 72, I 76, I 94, 20I, 205, 208, 209, 230, 232, 233, 234,255 
I

Iliad, 25

Insects (see Birds, Scale, Spraying)

Intensive farming, $15,240-271$

Italy (birds), 300,301

$\mathrm{J}$

Jefferson, cited, 326; quoted, 27

$\mathrm{K}$

Kainit, 207

Keeping young, 327

Kalbfus, cited, 276

\section{L}

Labor conditions, II 4 ; fundamental question of, Ir9; locality, II6; season, I15; treatment of, 123

Lacustrine, 21, 23

La Hontan, 45, 97

Lake Como, 30I, 302

Lake Dwellers, 21

Lake Erie, 139

Lake Geneva, 21

Lake Shore Valley, 12, 16, 30, 34, 37: described, 42-47; berries in, Iro; labor in, 117; location, 126; spraying in, 128; altitude, 139; adapted to grapes, 155,161 , I7I; geology, 182

Land, feeding the, 18, 19, 141, $142,175^{-210}$

La Salle, 45, 46, 97, 320

Leaf-hopper, 158

Lines of trade and travel, 37

Longfellow, quoted, 326

Louis XIV, 54

Law, John, 24I

Lucullus, 54

\section{M}

Mayflower, the, 9, 334

Managgio, 301, 302

Michigan, 47

Mill, J. S., 214

Mississippi Bubble, the, 24I

Montmorenci cherry, 6 (see Cherry)

Muriate of potash, 207
$\mathrm{N}$

Napoleon, 27, 214, 324, 325, 335, 336

"Neville Farm," 243-271

Newton, Isaac, 215

New York Evangelist, the, 21

New York Tribune, the, 262

New Jersey, 37

New Zealand, 39, 40

Nitrate of soda, 107, 184, 193, 202, 203

Nitrogen, 22, 172, 187, 200, 201, 202, 204, 205, 207

Notes on Virginia, 27

\section{O}

Orchard, cultivation, I48, 149, I50: planting (spaces), 74; setting out trees, 81, 82, 84; trimming, I35, I36, 249

\section{$\mathbf{P}$}

Package law, 129

Palestine, 284

Parton, quoted, 215

Pears, 87 ; blight, 88

Pennsylvania, 39,47

Pennsylvania R.R., 128

Perry, Commodore, 46, 240

Phosphate, 193, 200; see Fertilizer

Phosphoric acid, 172, 201, 202, 204, 205

Pittsboro, S. C., 284

Plant food, $83,179,180,184,192$

Plants, food, I80; our ignorance of, 193, 194, 195; growth, 178, I 79,184

Plato, 21 5, 326, 34I

Plums (prunes), 89, 90, 135

Poor Richard, 56

Pope, Alexander, 162

Potash, I9; chickweed as, 143, 187, 201, 205

Potato bug, 275

Prince Edward Island, 1 I9

Profits in fruit-farming, 240-271

Prunes (plums), 90, 9I

Pyrethrum, IIo

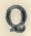

Quince, 95 
R

Raffael, 25

Raspberries, 107, 108

Richmond, Early (cherry), 6; see Cherry

Riviera, 273

"Roccolo," a, 3or

Root-worm, 152

Roots, setting out, 72, 75; spacing (table), 73

Rust, 108

\section{S}

Scale, 88, 91, 156; propagation, 282; (see also Birds)

Scott, Sir Walter, 26

Shakespeare, cited, I, 25, 26, 53 , 215,326 ; quoted, $256,317,318$

Silurian Age, 42

Smedley, Dr. James, 33I

Snow as cover crop, I45

Soil, cropping, 200; drainage (see); dead, 193; exhaustion, 233; making, I8I; preparation, 176, 181, 183, 197, 198, 235

South America, 49

Spencer, Herbert, 326

South Carolina rock, 202

Spraying, 151, 159, 160 also Birds, Scale)

Spraying machines, 159, I60

Stone Age, 35

Strawberries, 105, 106
Sub-soiling, 79, 80, 81; (see also Drainage)

$\mathrm{T}$

Tacitus, 25

Tankage, 202

Taylor, General, 19

Texas, 126

Thanksgiving Day, 322

Thrip, the, 158

Tivoli, 324

\section{V}

Vines, 140 (see Grapes)

Virgil, 25

\section{W}

Walpole, II3

Washington, George, 27, 53, 58, 215

Waterloo, 335

Watering the ground, 190, 191

Weather, the, 15 ; signs, $256-25^{8}$

Webster, cited, 58 ; quoted, 19 , 23

Wesley, John, quoted, 54

White, President, cited, 120

Whitman, Walt, 324

\section{Z}

Zeno, 326 


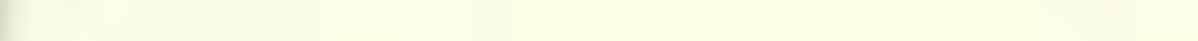







\section{PLEASE DO NOT REMOVE \\ CARDS OR SLIPS FROM THIS POCKET}

\section{UNIVERSITY OF TORONTO LIBRARY}

BioMed 
